Prepared in cooperation with the City of Madison and Wisconsin Department of Natural Resources

\title{
Evaluation of Turf-Grass and Prairie-Vegetated Rain Gardens in a Clay and Sand Soil, Madison, Wisconsin, Water Years 2004-08
}

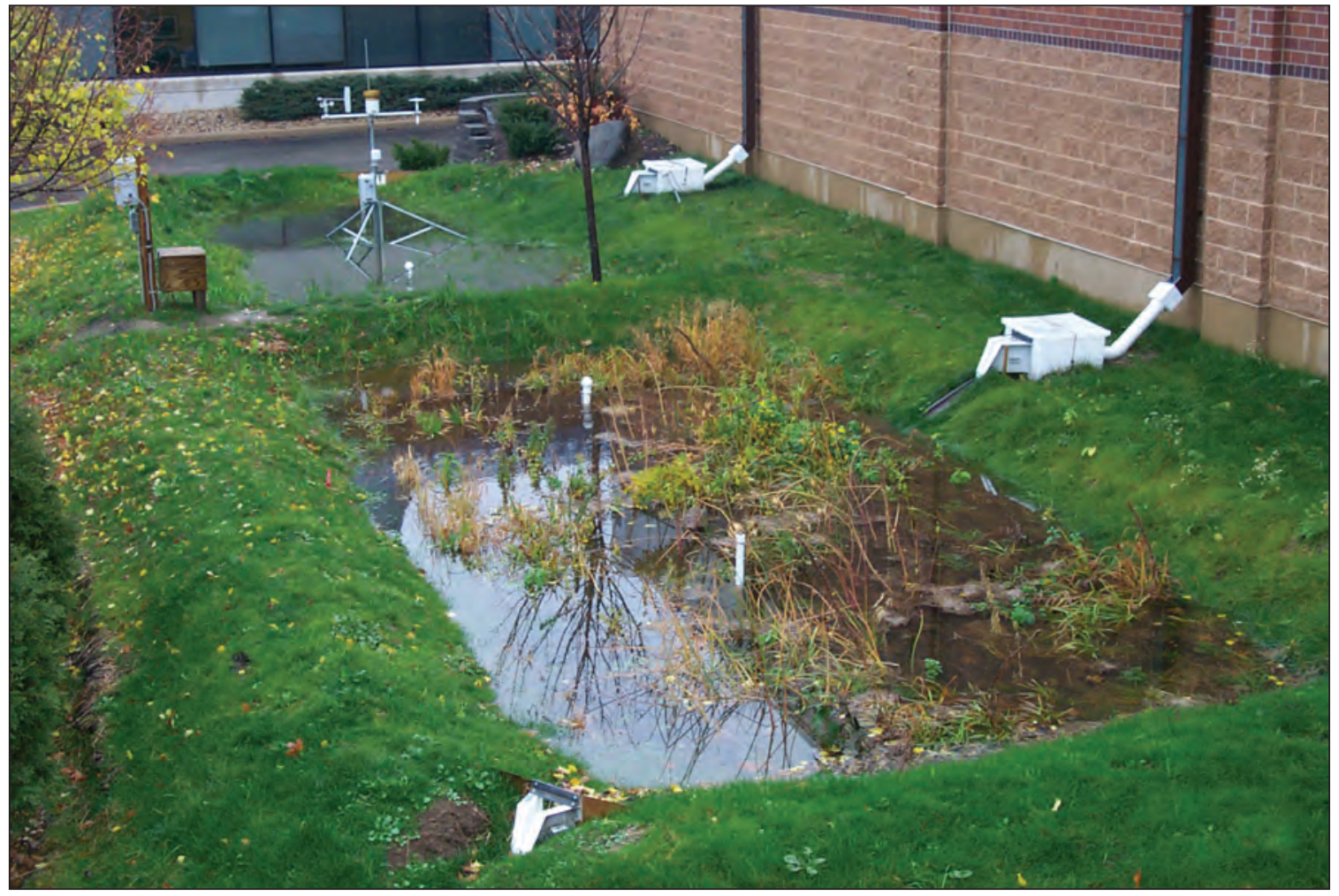

Scientific Investigations Report 2010-5077 
Cover: Photograph showing instrumentation used at the clay rain gardens, Madison, Wisconsin. 


\section{Evaluation of Turf-Grass and Prairie-Vegetated Rain Gardens in a Clay and Sand Soil, Madison, Wisconsin, Water Years 2004-08}

By William R. Selbig, U.S. Geological Survey, and Nicholas Balster, University of Wisconsin

Prepared in cooperation with the City of Madison and Wisconsin Department of Natural Resources

Scientific Investigations Report 2010-5077 


\title{
U.S. Department of the Interior \\ KEN SALAZAR, Secretary
}

\section{U.S. Geological Survey \\ Marcia K. McNutt, Director}

\section{U.S. Geological Survey, Reston, Virginia: 2010}

\author{
For more information on the USGS - the Federal source for science about the Earth, its natural and living resources, \\ natural hazards, and the environment, visit http://www.usgs.gov or call 1-888-ASK-USGS \\ For an overview of USGS information products, including maps, imagery, and publications, \\ visit http://www.usgs.gov/pubprod \\ To order this and other USGS information products, visit http://store.usgs.gov
}

\begin{abstract}
Any use of trade, product, or firm names is for descriptive purposes only and does not imply endorsement by the U.S. Government.

Although this report is in the public domain, permission must be secured from the individual copyright owners to reproduce any copyrighted materials contained within this report.
\end{abstract}

Suggested citation:

Selbig, W.R., and Balster, Nicholas, 2010, Evaluation of turf-grass and prairie-vegetated rain gardens in a clay and sand soil, Madison, Wisconsin, water years 2004-08: U.S. Geological Survey Scientific Investigations Report 2010-5077, 72 p. 


\section{Contents}

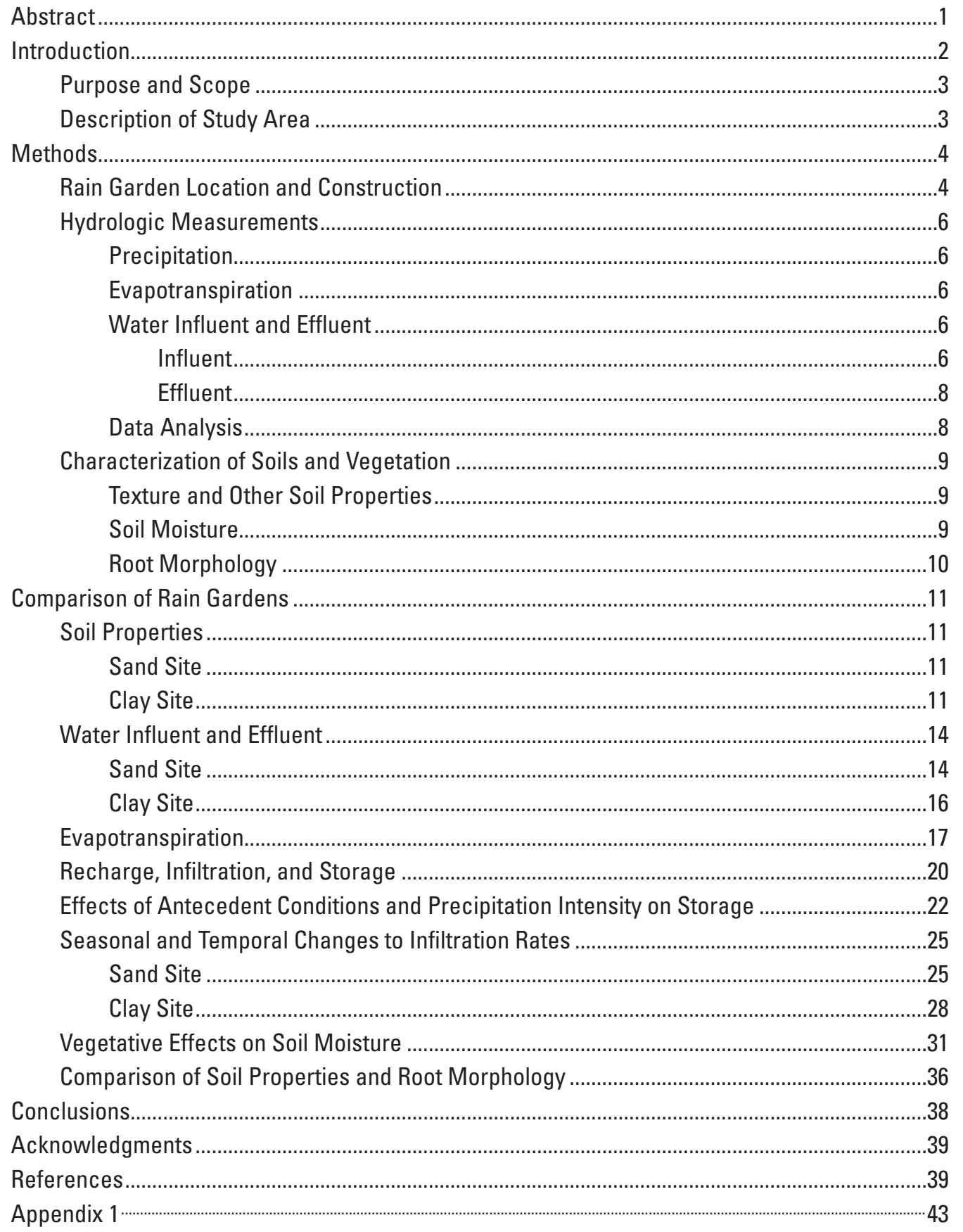




\section{Figures}

Figure 1. Map showing location of rain garden study areas in Madison, Wisconsin $\ldots \ldots \ldots$... 3

Figure 2. Photographs showing individual plugs of various prairie species planted in the prairie rain gardens in the $A$, clay site, and $B$, sand site $\ldots \ldots \ldots \ldots \ldots \ldots \ldots \ldots \ldots$

Figure 3. Photograph showing instrumentation used at the clay rain gardens $\quad \ldots \ldots \ldots \ldots \ldots$

Figure 4. Photograph showing instrumentation used the sand rain gardens, showing the turf garden setup

Figure 5. Photograph showing weather station instrumentation used for precipitation and to estimate reference evapotranspiration

Figure 6. Graph showing example calculation of average infiltration rate using simplified falling-head technique in the sand rain gardens

Figure 7. Photograph showing soil-moisture sensors spaced at 20-centimeter intervals on soil probe

Figure 8. Cross section of soils and subsurface deposits between the turf and prairie rain gardens in sand

Figure 9. Cross section of soils and subsurface deposits between the turf and prairie rain gardens in clay

Figure 10. Graph showing precipitation totals at the clay and sand rain gardens study sites during each study year.

Figure 11. Photograph showing accumulation of ice in downspouts draining rooftop runoff at the clay study site

Figure 12. Graph showing annual distribution of reference evapotranspiration and range of estimated evapotranspiration for prairie rain gardens at the sand and clay study sites

Figure 13. Graph showing cumulative frequency of precipitation measured at the sand and clay study sites between water years 2004-08

Figure 14A. Results of CART analysis illustrating relevant factors that determine if water would pool in the sand rain gardens

Figure 14B. Results of CART analysis illustrating relevant factors that determine if water would pool in the clay rain gardens

Figure 15. Boxplots showing comparison of infiltration rates by water year in the sand rain gardens

Figure 16. Boxplots showing comparison of infiltration rates by season in the sand rain gardens

Figure 17. Boxplots showing comparison of infiltration rates by water year in the clay rain gardens

Figure 18. Boxplots showing comparison of infiltration rates by season in the clay soil rain gardens

Figure 19A.Graph showing comparison of soil moisture at $0.5,1.25$, and 2.0 feet below land surface in the prairie-clay rain garden, May through September 2005

Figure 19B.Graph showing comparison of soil moisture at 0.5, 1.25, and 2.0 feet below land surface in the turf-clay rain garden, May through September, 2005

Figure 20. Graph showing changes in soil moisture with increasing depth before, 1 hour, 3 days, and 6 days after flooding the prairie-clay rain garden, September 2008.

Figure 21. Graph showing comparison of soil moisture for July 2005 and 2007 at 1.6 feet below land surface in the turf-sand rain garden and 2.6 feet below land surface in the prairie-sand rain garden.... 


\section{Tables}

Table 1. List of vegetative species planted in the prairie-sand and prairie-clay rain gardens, Madison, Wisconsin

Table 2. Summary of physical and botanical characteristics identified in the turf-grass and prairie rain gardens in a sand soil and in a clay soil

Table 3. Summary of influent and effluent volume measured in the turf-grass and prairie rain gardens at the sand and clay soil study sites, water years 2004-08, Madison, Wisconsin

Table 4. Summary of water balance, after normalizing by rain-garden area, in the turf and prairie rain gardens in sand and clay, water years 2004-08

Table 5. Summary of vegetative species identified by Craig (2007) in the turf-grass and prairie rain gardens in sand and clay and computed landscape coefficient for estimating evapotranspiration

Table 6. Comparison of observed and predicted precipitation events exceeding the storage capacity, both above- and below-ground, in the turf- and prairie-clay rain gardens, April through November, water years 2004-07

Table 7. Statistical summary of infiltration rates in the turf-grass and prairie rain gardens in sand and clay

Table 8. Soil-profile descriptions of the turf-clay and prairie-clay rain gardens, October 2008

Table 9. Rooting dynamics below the turf-clay and prairie-clay rain gardens, October 2008

\section{Abbreviations}

CART Classification and regression tree

ET evapotranspiration

hr hour

K landscape coefficient

min minute

nmol nanomole

NOAA National Oceanic and Atmospheric Administration

RLD root length density

SOM soil organic matter

SRL specific root length

WDNR Wisconsin Department of Natural Resources

yr year 


\section{Conversion Factors}

Inch/Pound to SI

\begin{tabular}{|c|c|c|}
\hline Multiply & By & To obtain \\
\hline \multicolumn{3}{|c|}{ Length } \\
\hline inch (in.) & 2.54 & centimeter $(\mathrm{cm})$ \\
\hline foot $(\mathrm{ft})$ & 0.3048 & meter $(\mathrm{m})$ \\
\hline mile (mi) & 1.609 & kilometer (km) \\
\hline \multicolumn{3}{|c|}{ Area } \\
\hline square foot $\left(\mathrm{ft}^{2}\right)$ & 0.09290 & square meter $\left(\mathrm{m}^{2}\right)$ \\
\hline \multicolumn{3}{|c|}{ Volume } \\
\hline $\begin{array}{l}\text { cubic inch }\left(\mathrm{in}^{3}\right) \\
\text { cubic foot }\left(\mathrm{ft}^{3}\right)\end{array}$ & $\begin{array}{l}16.39 \\
0.02832\end{array}$ & $\begin{array}{l}\text { cubic centimeter } \\
\text { cubic meter }\left(\mathrm{m}^{3}\right)\end{array}$ \\
\hline \multicolumn{3}{|c|}{ Flow rate } \\
\hline inch per hour (in/hr) & 0.0254 & meter per hour $(\mathrm{m} / \mathrm{h})$ \\
\hline \multicolumn{3}{|l|}{ SI to Inch/Pound } \\
\hline Multiply & By & To obtain \\
\hline \multicolumn{3}{|c|}{ Length } \\
\hline centimeter $(\mathrm{cm})$ & 0.3937 & inch (in.) \\
\hline millimeter (mm) & 0.03937 & inch (in.) \\
\hline $\operatorname{meter}(\mathrm{m})$ & 3.281 & foot $(\mathrm{ft})$ \\
\hline \multicolumn{3}{|c|}{ Volume } \\
\hline cubic centimeter $\left(\mathrm{cm}^{3}\right)$ & 0.06102 & cubic inch $\left(\right.$ in $\left.^{3}\right)$ \\
\hline \multicolumn{3}{|c|}{ Mass } \\
\hline $\operatorname{gram}(\mathrm{g})$ & 0.03527 & ounce, avoirdupois (oz) \\
\hline \multicolumn{3}{|c|}{ Density } \\
\hline gram per cubic centimeter $\left(\mathrm{g} / \mathrm{cm}^{3}\right)$ & 62.4220 & pound per cubic foot $\left(\mathrm{lb} / \mathrm{ft}^{3}\right)$ \\
\hline
\end{tabular}

Temperature in degrees Celsius $\left({ }^{\circ} \mathrm{C}\right)$ may be converted to degrees Fahrenheit $\left({ }^{\circ} \mathrm{F}\right)$ as follows:

$$
{ }^{\circ} \mathrm{F}=\left(1.8 x^{\circ} \mathrm{C}\right)+32 \text {. }
$$

Horizontal coordinate information is referenced to the 1991 adjustment of the North American Datum of 1983 (NAD 83/91).

Water year in USGS reports is the 12-month period October 1 through September 30. The water year is designated by the calendar year in which it ends. 


\title{
Evaluation of Turf-Grass and Prairie-Vegetated Rain Gardens in a Clay and Sand Soil, Madison, Wisconsin, Water Years 2004-08
}

\author{
By William R. Selbig, U.S. Geological Survey, and Nicholas Balster, University of Wisconsin
}

\section{Abstract}

The U.S. Geological Survey, in cooperation with a consortium of 19 cities, towns, and villages in Dane County, Wis., undertook a study to compare the capability of rain gardens with different vegetative species and soil types to infiltrate stormwater runoff from the roof of an adjacent structure. Two rain gardens, one planted with turf grass and the other with native prairie species, were constructed sideby-side in 2003 at two locations with different dominant soil types, either sand or clay. Each rain garden was sized to a ratio of approximately 5:1 contributing area to receiving area and to a depth of 0.5 foot.

Each rain garden, regardless of vegetation or soil type, was capable of storing and infiltrating most of the runoff over the 5-year study period. Both rain gardens in sand, as well as the prairie rain garden in clay, retained and infiltrated 100 percent of all precipitation and snowmelt events during water years 2004-07. The turf rain garden in clay occasionally had runoff exceed its confining boundaries, but was still able to retain 96 percent of all precipitation and snowmelt events during the same time period. Precipitation intensity and number of antecedent dry days were important variables that influenced when the storage capacity of underlying soils would become saturated, which resulted in pooled water in the rain gardens.

Because the rooftop area that drained runoff to each rain garden was approximately five times larger than the area of the rain garden itself, evapotranspiration was a small percentage of the annual water budget. For example, during water year 2005, the maximum evapotranspiration of total influent volume ranged from 21 percent for the turf rain garden in clay to 25 percent for the turf rain garden in sand, and the minimum ranged from 12 percent for the prairie rain garden in clay to 19 percent for the prairie rain garden in sand. Little to no runoff left each rain garden as effluent and a small percentage of runoff returned to the atmosphere through evapotranspiration; therefore, the remainder was considered recharge. During water year 2005, recharge was 81 to 75 percent of total influent volume for the prairie- and turf-rain gardens in sand and 87 to 78 percent for the prairie- and turf-rain gardens in clay, respectively. Maximum recharge volumes ranged from 90 to 94 percent of the total influent volume in the turf and prairie rain gardens in sand and occurred during water year 2004. Maximum recharge in the turf and prairie rain gardens in clay ranged from 89 percent during water year 2007 to 98 percent during water year 2004.

Median infiltration rates were an order of magnitude greater for rain gardens planted in sand than for those in clay, regardless of vegetation type. Under similar soil conditions, rain gardens planted with turf grass had lower median infiltration rates than those planted with prairie species. Median infiltration rates were 0.28 and 0.88 inches per hour in the turf and prairie rain gardens in clay, respectively, and 2.5 and 4.2 inches per hour in the turf and prairie rain gardens in sand, respectively. In general, infiltration rates were greater during spring (April and May) and summer (June through August) months.

Of the six observed exceedences of the storage capacity of the turf rain garden in clay between April-November during 2004-07, five were predicted by use of a combination of the normalized surface storage volume, the median infiltration rate, and an estimate of specific yield for soils under the rain garden to a depth equal to the uppermost limiting layer. By use of the same criteria, in water year 2008, when the contributing drainage area to the prairie rain garden in clay was doubled, all four observed exceedences of the total storage capacity were predicted. The accuracy of the predictions of when the total storage capacity of the rain gardens would be exceeded indicates that by applying measurements of the appropriate soil properties to rain garden design, environmental managers and engineers may improve the tailoring of design specifications of rain gardens for new or retrofitted areas.

An examination of soil structure and the root systems in the rain gardens in clay revealed striking differences between turf and prairie vegetation. Soils under the prairie rain garden, although they possessed the remnants of a limiting clay layer, appeared well-drained, whereas those under the turf rain garden showed marked evidence of a perched water table. Although roots were present in all horizons sampled within clay soil in the prairie rain garden, roots were limited to the upper A and Bt horizons within the turf rain garden. Collectively, these differences point to greater pedoturbation and soil development in the prairie rain garden in clay relative to the rain garden planted with turf grass. 


\section{Introduction}

The adverse impacts of urbanization on stormwaterrunoff quantity and quality have been well documented (U.S. Environmental Protection Agency, 1983, Bannerman and others, 1993). When impervious area increases, precipitation that previously would have infiltrated into surrounding soils is instead collected and conveyed by hard surfaces into nearby receiving water bodies. Collectively, impervious areas introduced by traditional urban landscapes lead to more diverse pollutants in overland flow, reduced pollutant removal during overland flow, and reduced infiltration (Davis, 2005). By reducing the volume of runoff that would percolate into underlying soils under natural conditions, urban development can reduce the supply of groundwater that is beneficial for wetlands, streams, and lakes and vital for human consumption (Simmons and Reynolds, 1982). Traditional stormwater management has focused primarily on the use of detention ponds for reducing flood peaks and preventing localized flooding. Although these practices have been successful in reducing episodic localized flooding and improving the quality of runoff, they have not addressed groundwater recharge issues or other aspects of altered streamflow that negatively impact stream ecosystems and human uses (House and others, 1993; Pettersson, 1998; Winer, 2000; Marlin and others, 2002).

As development continues to push further into our Nation's landscape, controlling nonpoint sources of contamination, replenishing groundwater supplies, and protecting natural waterways have become important tasks for the regulatory community. Environmental managers are charged with developing new strategies that promote a balance between existing and expanding urban areas and the environmental challenges they impose. To this end, the Wisconsin Department of Natural Resources (WDNR) promulgated a series of performance standards and prohibitions with regard to nonpoint stormwater sources (Wisconsin Administrative Code, 2002). These standards are intended to be minimum benchmarks of performance necessary to achieve water-quantity and quality goals. Specifically, the standards require that new residential areas infiltrate 90 percent of predevelopment infiltration volume for an average rainfall year and that commercial and other nonresidential land uses infiltrate 60 percent of predevelopment infiltration volume (Wisconsin Administrative Code, 2002).

Recent trends in urban-runoff mitigation have prompted technologies that focus on infiltration. One such technology, known as a rain garden, is a shallow depression that gathers runoff generated from nearby impervious surfaces and infiltrates that runoff into the ground. In addition to reducing or limiting the quantity of stormwater runoff, rain gardens provide some level of water-quality benefit by settling, filtration, adsorption, decomposition, ion exchange, and volatilization (Prince George's County, 1993). Rain gardens are commonly used to retrofit existing urban areas, where land requirements often preclude larger structures. Although the use of rain gardens is increasing, there appears to be no clear consensus on how soils at a site might limit the use of an infiltration device. In the State of Wisconsin, an exemption is granted to sites that fall under the purview of infiltration technical standards if the infiltration rate of the soil is less than $0.6 \mathrm{in} / \mathrm{hr}$ (Wisconsin Administrative Code, 2002). This exemption limits the use of infiltration in many areas in Wisconsin. When expansion of the use of rain gardens and other infiltration devices is considered, additional information about soil amendments and sizing criteria is likely to reduce the uncertainty associated with requiring infiltration in soils with low infiltration rates.

Previous studies have evaluated the infiltrative and water-quality benefits of rain gardens sited in various soil types. Results of these studies suggest rain gardens can be an effective way to infiltrate stormwater runoff from localized sources (Dietz and Clausen, 2005; Dietz and Clausen, 2006; Smith and Hunt, 2007). However, most of these studies may not have represented true field conditions, because underground impermeable membranes were often installed to seal the rain garden. This was done to capture all percolated water, thus ensuring accurate volumetric mass-balance calculations; it also disturbed the native soil structure in the process. Furthermore, many rain garden manuals recommend planting vegetation that is native to the area and do not consider a more commonly accepted ground cover such as turf grass (Prince George's County, 1993; Wisconsin Department of Natural Resources, 2003; City of Lenexa, 2003). Native prairie vegetation has been associated with a dense root structure capable of growing to substantial depths below the ground surface. This type of vegetation is assumed to promote runoff interception and infiltration; however, few studies have verified this claim and none have examined the rooting character of these vegetation types within urban rain gardens. This lack of information about below-ground processes has arguably limited ability to predict the contribution of rain gardens to stormwater management (Eissenstat and others, 2006). Other studies have shown that turf grasses can also limit overland runoff (Kussow, 1995). Steinke and others (2007) measured significantly lower runoff volumes from an experimental buffer strip planted with turf grass than those of an adjacent plot planted with emergent prairie vegetation; turf grass may be more suitable for homeowners to use due to cost and maintenance concerns. However, little is known about the interactions between the soil and the variety of plant species used in rain garden design. This absence of data is understandable given the difficulty of assessing root dynamics and morphology on site without destructive sampling. However, it limits understanding of plant-soil dynamics in rain gardens, including the cycling of carbon and minerals, rootwater relationships, and the thus long-term functionality of these bioengineered systems (Asseng and others, 1997).

For these reasons, the U.S Geological Survey, in cooperation with a consortium of 19 cities, towns, and villages in Dane County, Wis., undertook a study to evaluate the 
effectiveness of rain gardens with different soil types and vegetative species for infiltrating stormwater runoff. Two rain gardens, one planted with turf grass and the other with native prairie species, were constructed side-by-side in one location where sand was the dominant soil type and another location where clay was the dominant soil type. Instruments were installed to measure the volumetric mass balance of each rain garden from late 2003 through 2008. This study supports an ongoing effort to identify existing and new methods to reduce the loss of recharge to groundwater from urban areas.

\section{Purpose and Scope}

This report documents the methods used in and the results from a study to determine if soil type or vegetative species, or both, in a rain garden have an effect on the rate of infiltration of stormwater runoff. Two rain gardens with different vegetative species and soil types were evaluated, and their soil and vegetative characteristics were documented. The controlled construction of the rain gardens and installation of instrumentation were important for accurate measurement of hydrologic, soil, and vegetative characteristics, and these methods are described. The capability of a water balance for estimating recharge at each rain garden is evaluated, and the storage and infiltration characteristics for different soils and vegetation types are compared. Finally, the results of an assessment of root-mass development in a limiting clay layer are presented.

\section{Description of Study Area}

Madison, Wis., has a population of 208,054 (based on the 2000 census). The climate is typical of interior North America, with a large annual temperature range and frequent short-period temperature changes. Nearly 60 percent of the annual precipitation falls in May through September, and annual precipitation averages 31.7 in. (National Oceanic and Atmospheric Administration, 2005). Both rain garden study areas were located approximately $2 \mathrm{mi}$ apart near the western boundaries of the city (ig. 1).

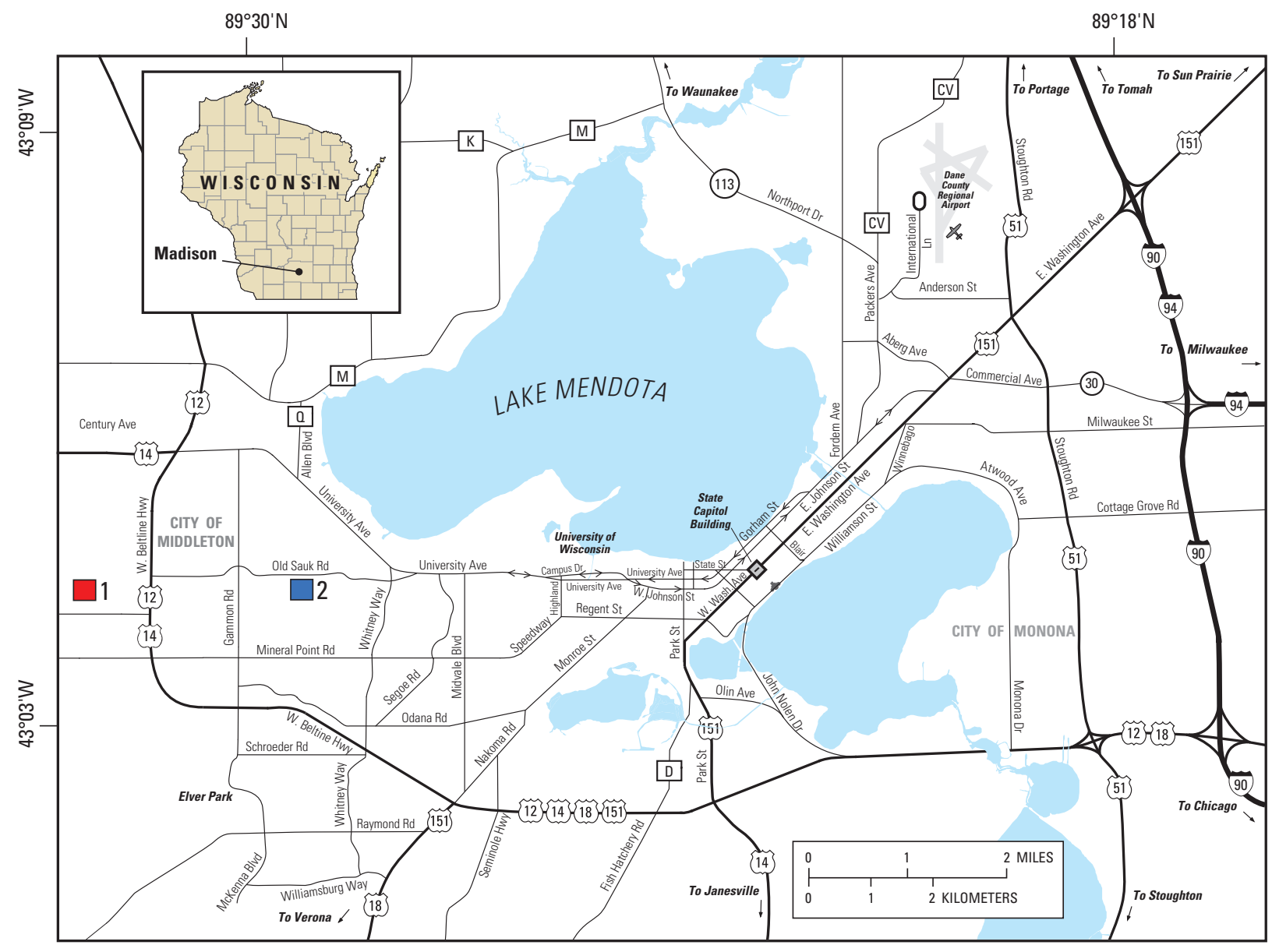

1 Rain gardens in clay soil

2 Rain gardens in sandy soil

Figure 1. Location of rain garden study areas in Madison, Wisconsin. 


\section{Methods}

\section{Rain Garden Location and Construction}

Two geographic areas were selected in Madison, Wis., to represent different soil conditions. The first location had predominantly sandy soils and the second contained more clay and silt. Two rain gardens were constructed side-byside at each location in June 2003. Each rain garden received approximately equal amounts of runoff from the roof of a nearby structure. In each location, one rain garden was planted with turf grass and the adjacent rain garden was planted with native prairie vegetation. Although soils at each rain garden location are variable in texture, each was primarily dominated by soils that could be generalized as sand or clay and was therefore assigned a single soil type to simplify discussion. To clarify reference to vegetation, each rain garden will be referred to by vegetative species followed by the soil type in which it was located. The resulting rain gardens are subsequently called turf-sand, prairie-sand, turf-clay, and prairie-clay.

The city of Madison constructed the rain gardens by use of equipment typically available to homeowners and landscaping crews. Skid loaders were used to excavate all parent material and assisted in forming earthen berms around the rain garden boundaries to assure that no runoff from areas other than the roof entered the rain garden. Approximately 4 to 6 in. of screened compost from the Dane County compost facility was mixed by use of a rototiller into parent material at the bottom of each rain garden. A uniform, level surface was approximated by use of survey equipment. Turf rain gardens were seeded with a grass mix of red fescue, Kentucky bluegrass, and perennial rye grass, then fertilized and matted. The prairie rain gardens were planted with dormant plugs spaced approximately $1 \mathrm{ft}$ apart, then fertilized (fig. 2). Table 1 details the diversity of species planted in each prairie rain garden.

Construction of each rain garden was completed in June 2003; however, an extended drought during the summer of 2003 inhibited root growth in the turf rain gardens, but by the following spring (2004), the grass was well established in both turf gardens. The prairie rain gardens did not experience the same retardation of vegetative growth and appeared well established by fall 2003. This may be a result of the use of dormant plantings rather than seed.

Rain gardens in sand were built next to a municipal maintenance garage located in the Owen Conservation Park, a hummocky area on the west side of Madison (fig. 1). Soils in this area consist of silt loam, sandy clay loam, and sandy loam (Natural Resources Conservation Service, 2009). The parent material of soils in this area consists of till typical of unconsolidated glacial deposits in drumlins created during the Wisconsin glaciation (Mickelson, 2007). Each rain garden received runoff from the roof of the maintenance garage. The total area of the roof was $1,026 \mathrm{ft}^{2}$, and it was covered with
Table 1. List of vegetative species planted in the prairie-sand and prairie-clay rain gardens, Madison, Wis.

\begin{tabular}{ll}
\hline \multicolumn{1}{c}{ Botanical name } & \multicolumn{1}{c}{ Common name } \\
\hline Physostegia virginiana & Obedient plant \\
Rudbeckia subtomentosa & Sweet black-eyed susan \\
Iris pseudacorus & Yellow flag iris \\
Chelone glabra & White turtlehead \\
Lobelia cardinalis & Cardinal flower \\
Scirpus atrovirens & Dark green bulrush \\
Scirpus validus & Great bulrush \\
Carex typhina & Common cattail sedge \\
Pycnanthemum virginianum & Mountain mint \\
Silene stellata & Starry campion \\
Aquilegia canadensis & Wild columbine \\
Baptisia bracteata & Cream wild indigo \\
Aster laevis & Smooth aster \\
Monarda & Wild bergamot \\
Schizachyrium scoparium & Little bluestem \\
Bouteloua curtipendula & Sideoats grama grass \\
Asclepias incarnata & Swamp milkweed \\
Sagittaria latifolia & Narrowleaf arrowhead \\
\hline &
\end{tabular}

asphalt composite shingles commonly found on residential dwellings. One-half of the total roof area $\left(513 \mathrm{ft}^{2}\right)$ was directed into one of two downspouts draining into the turf grass or prairie rain gardens. Each rain garden was approximately $100 \mathrm{ft}^{2}$, or one-fifth the size of the roof area draining to it. Water was allowed to pond up to a depth of approximately 6 in. before leaving the rain garden as discharge.

Rain gardens in clay were built next to a municipal watersupply pump house approximately $2 \mathrm{mi}$ west of the sand rain gardens (fig. 1). Similar to the sand rain garden location, soils in this area range from a sandy loam to a clay loam (Natural Resources Conservation Service, 2009). The parent material of soils in this area consists of a sandy matrix of glacial outwash and till typical of unconsolidated glacial deposits of the Milton end moraine during the last part of the Wisconsin glaciation (Mickelson, 2007). However, excavations from urban development over the last decade disturbed the native landscape, resulting in post-construction soils that were heavily compacted prior to rain garden construction. Each rain garden received runoff from the roof of the municipal well house. The total area of the flat, rubber roof was $3,080 \mathrm{ft}^{2}$ and was designed to drain equally $\left(1,540 \mathrm{ft}^{2}\right)$ into one of two downspouts. Similar to the rain gardens in sand, the area of turf- and prairie-clay rain gardens was approximately one-fifth and one-fourth the size of the roof area draining to it (354 and $403 \mathrm{ft}^{2}$ ), respectively. Water was allowed to pond up to a depth of approximately 6 in. before leaving the rain garden as discharge. 

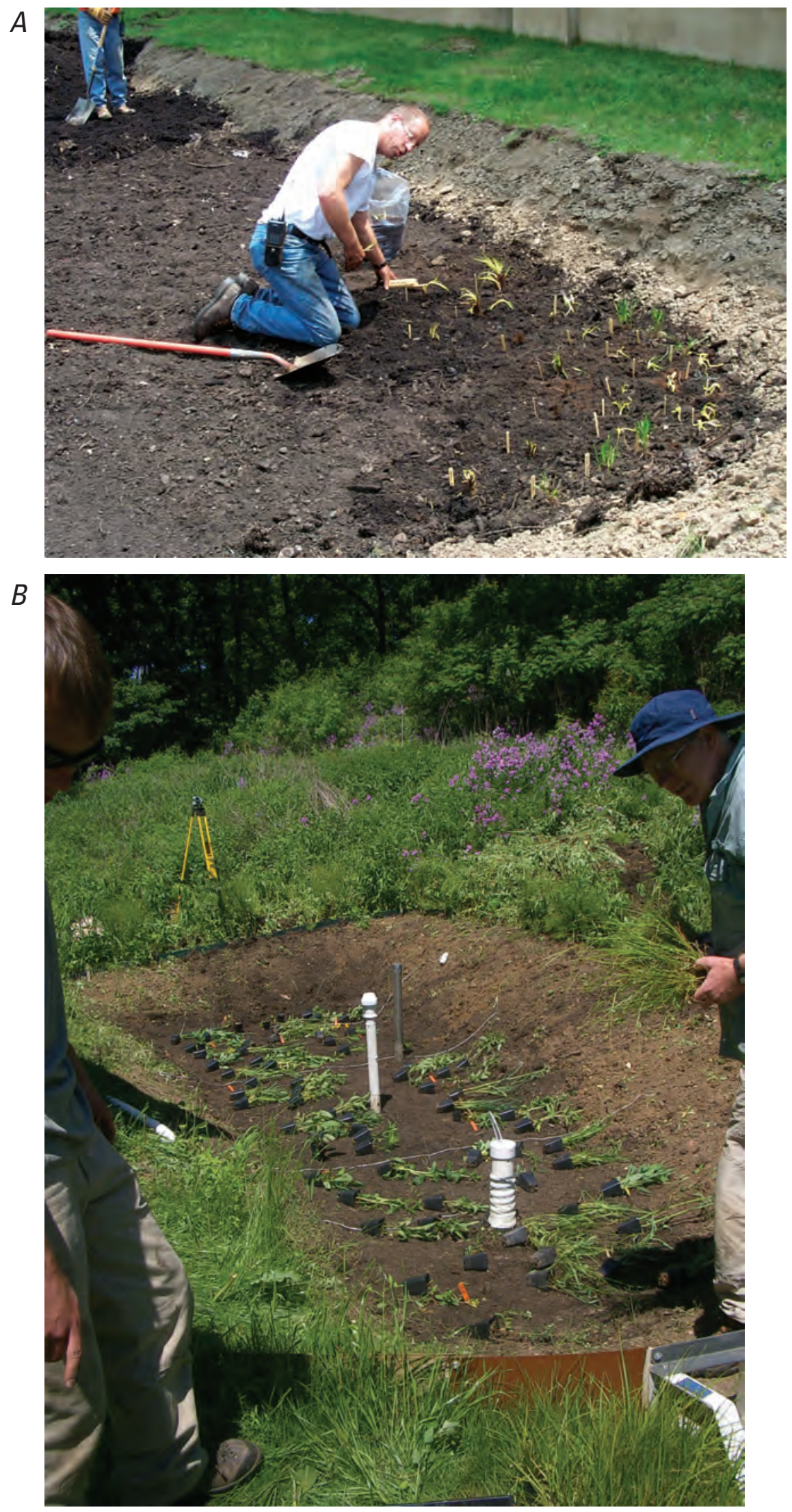

Figure 2. Individual plugs of various prairie species planted in the prairie rain gardens in the $A$, clay site, and $B$, sand site. 


\section{Hydrologic Measurements}

Stormwater runoff was measured from downspouts leading to each rain garden (figs. 3 and 4). The locations of the monitoring stations are shown in figure 1. Each monitoring station was equipped to measure water level, precipitation, subsurface soil-moisture content, and reference evapotranspiration. Data were measured, controlled, and stored by electronic dataloggers. Telephone modems allowed for automatic retrieval of data twice daily. Storm-event characteristics for runoff events at each rain garden location are detailed in appendix tables 1-1 and $\underline{1-2}$.

\section{Precipitation}

Continuous precipitation data were collected at each rain garden location by use of tipping-bucket rain gages calibrated to 0.01 in. (fig. 5). Although these rain gages were not designed to measure snowfall, precipitation during several runoff events during winter months (December-March) was in the form of rain instead of snow. Monthly precipitation totals during winter months were estimated from the National Oceanic and Atmospheric Administration (NOAA) weather station at the Dane County Regional Airport in Madison, Wis. (National Oceanic and Atmospheric Administration, 2003-07). Summaries of precipitation data from the clay and sand rain gardens are presented in appendix tables 1-1 and $\underline{1-2}$, respectively.

\section{Evapotranspiration}

Estimates of evapotranspiration were computed to characterize the volume of water lost to the atmosphere. To calculate reference evapotranspiration $\left(\mathrm{ET}_{\mathrm{o}}\right)$, solar radiation, air temperature, relative humidity, and wind speed were collected by use of a pyranometer, platinum resistance temperature detector, capacitive relative humidity sensor, and anemometer, respectively (fig. 5). Reference evapotranspiration, in millimeters, was computed every 5 min by use of the Penman-Monteith equation (Monteith and Unsworth, 1990; Allen and others, 1998) and was then summed into hourly and daily totals. A reference surface closely resembles a green, well-watered grass of uniform height, actively growing and completely shading the ground (Allen and others, 1998). Both rain gardens planted with turf grass closely resemble a reference surface. A landscape coefficient of 0.95 , based on published values for cool season grasses (Allen and others, 1998), was applied to the reference evapotranspiration in the turf rain gardens. Many of the vegetative properties, such as ground cover, canopy, and aerodynamic resistance in the rain garden planted with prairie vegetation were likely different from those in the turf rain gardens. Estimates of evapotranspiration in the prairie rain gardens were based on a range of published landscape coefficients for a variety of vegetative species commonly used in the landscaping industry. The landscape coefficient uses species type, density, and microclimate to estimate a correction factor to reference evapotranspiration (Costello and others, 2000). Average landscape coefficients representing "low" and "high" evapotranspiration were calculated for many of the species in the prairie rain gardens. A landscape coefficient $\left(\mathrm{K}_{\mathrm{L}}\right)$ for a specific vegetative species was determined using the following formula:

$$
\mathrm{K}_{\mathrm{L}}=\mathrm{K}_{\mathrm{s}} \times \mathrm{K}_{\mathrm{d}} \times \mathrm{K}_{\mathrm{mc}}
$$

where

$$
\begin{array}{cl}
\mathrm{K}_{\mathrm{s}} & \text { is the species factor; } \\
\mathrm{K}_{\mathrm{d}} & \text { is the density factor; and } \\
\mathrm{K}_{\mathrm{mc}} & \text { is the microclimate factor. } \\
\mathrm{K}_{\mathrm{L}} & \text { is then multiplied by the reference } \\
& \text { evapotranspiration to determine the final } \\
& \text { evapotranspiration for a specific vegetative } \\
& \text { species. A weighted average was used to } \\
& \text { enhance the accuracy of the representation } \\
& \text { of the abundance of each species identified } \\
& \text { in each rain garden. }
\end{array}
$$

\section{Water Influent and Effluent}

\section{Influent}

Stormwater runoff influent at the turf- and prairie-clay rain gardens was measured by means of a prerated $\mathrm{H}$-flume and shaft encoder (fig. 3). Rooftop runoff first traveled through the downspout dedicated to each rain garden into a buffer tank that prevented turbulent flow conditions. Water levels in the buffer tank would raise or lower a float and counterweight system connected to a shaft encoder, which was calibrated to the nearest $0.01 \mathrm{ft}$. The shaft encoder's point of zero flow was coincident with the invert of an H-flume of $0.8 \mathrm{ft}$ in height. Water levels in the buffer tank were used to compute an instantaneous discharge by use of the known H-flume rating. Storm-runoff volumes were computed by summing the 1-mininterval instantaneous discharge over the runoff duration.

Stormwater runoff influent at the turf- and prairie-sand rain gardens was measured by means of a tipping bucket and magnetic reed switch (fig. 4). Rooftop runoff first traveled through the downspout dedicated to each rain garden into a buffer tank. A small funnel was attached to the buffer tank to focus water into the tipping bucket Each tip of the bucket represented a known volume of water. After passing through the tipping bucket, runoff would flow into a drain tube leading into the rain garden. 


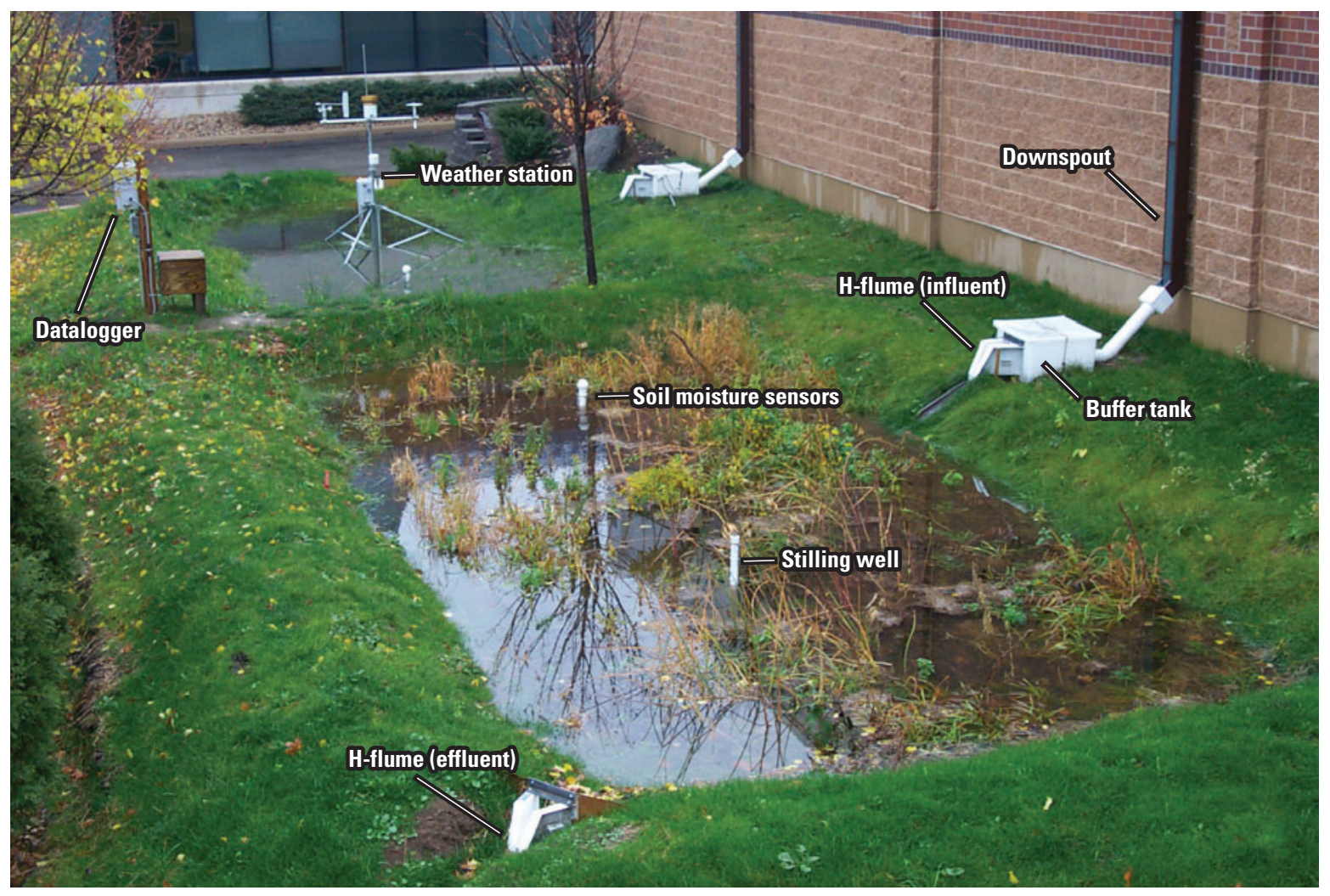

Figure 3. Instrumentation used at the clay rain gardens.

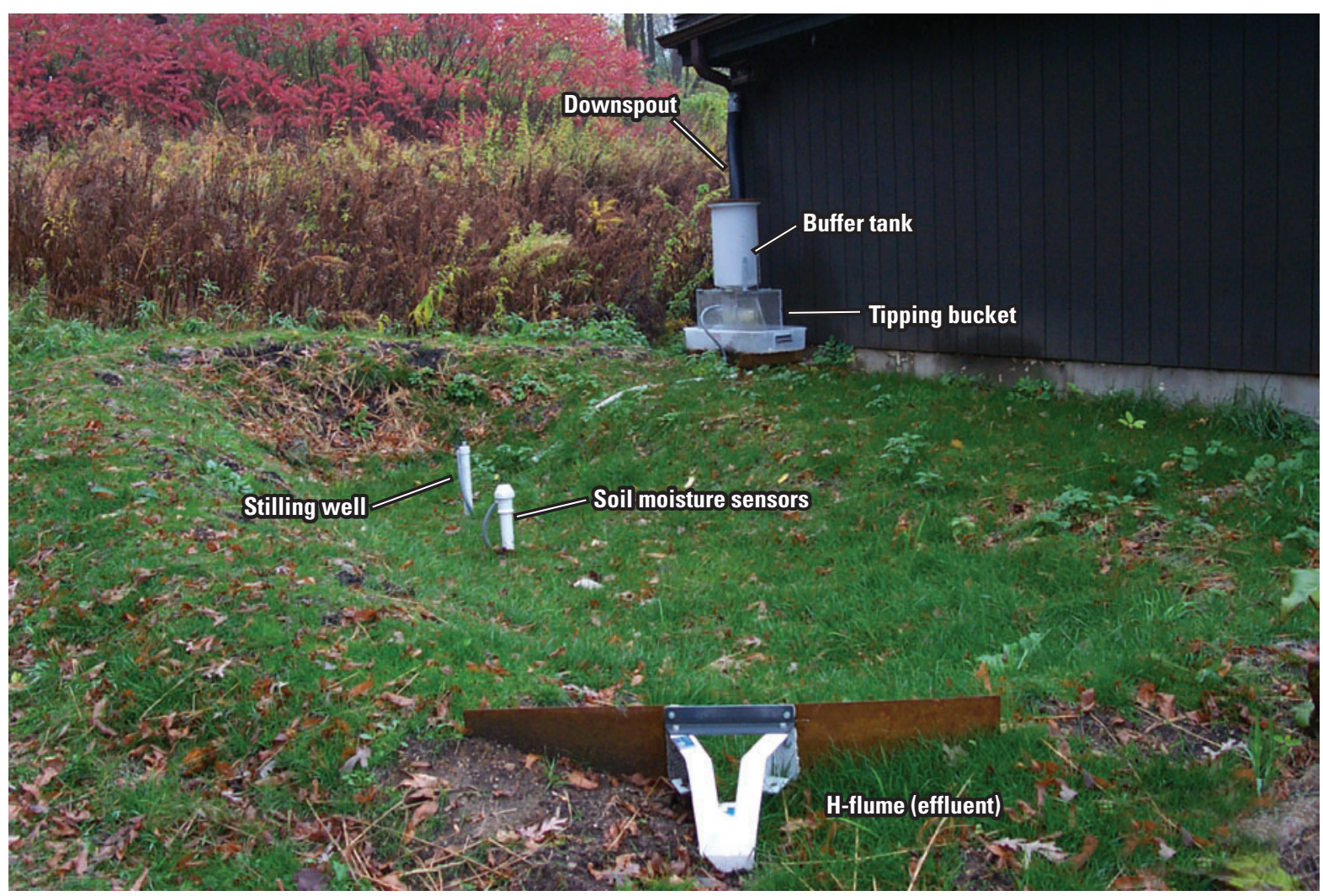

Figure 4. Instrumentation used at the sand rain gardens, showing the turf garden setup. 


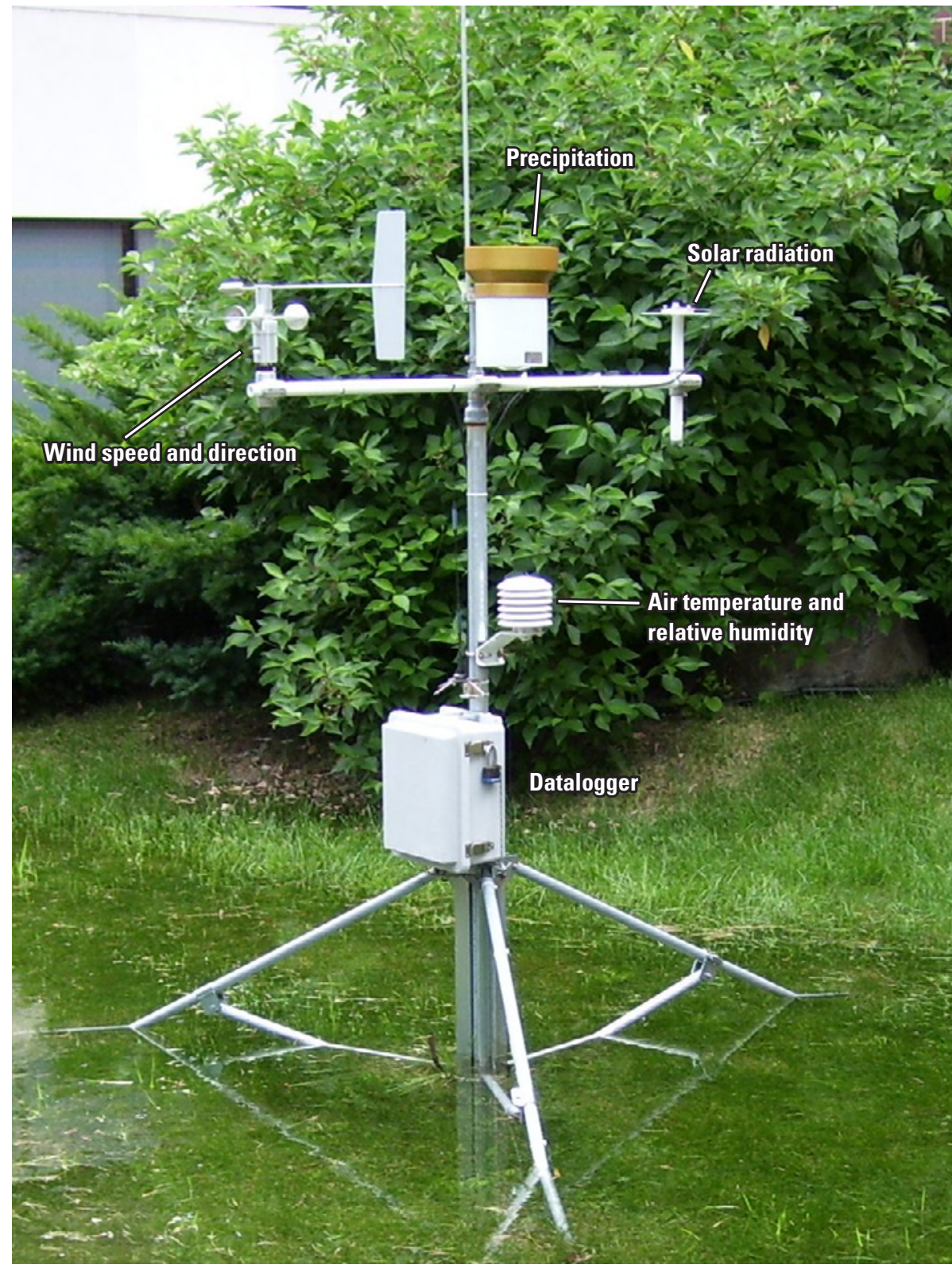

Figure 5. Weather station instrumentation used for precipitation and to estimate reference evapotranspiration.

\section{Effluent}

Water level in excess of 6 in. in each rain garden was discharged as effluent. A 0.6-ft prerated H-flume was used to control the rate of flow (figs. 3 and 4 ). Water levels in each rain garden were measured by means of a submersible pressure transducer, calibrated to $0.01 \mathrm{ft}$, placed inside a stilling well made of a smalldiameter polyvinyl chloride ("PVC") tube (figs. 3 and 4). Water level was measured in 0.01 -ft increments above the rain garden floor. Because the invert of the 0.6-ft $\mathrm{H}$-flume was at a known elevation above the rain garden floor, water levels above the flume invert were converted to an instantaneous discharge by use of the known H-flume rating. Storm-runoff volumes were computed by summing the 1-mininterval instantaneous discharge over the runoff duration.

\section{Data Analysis}

Classification and regression trees (CART) were used to visualize a relation between a dependent variable and a set of independent variables (Breiman and others, 1984). A CART analysis was done on each rain garden to understand which climatologic and hydrologic variables might determine when the rain garden would pool with water. The dependent variable was qualitatively termed "wet" or "dry" to describe whether or not a rain garden pooled with water during a discharge event. Quantitative independent variables including precipitation depth, total event volume, antecedent dry days, and 15-, 30-, and 60-min precipitation intensities were used to describe the hydrologic and climatologic conditions.

During "wet" periods, an estimate of the rate of infiltration was computed by use of a simplified falling head technique. Consistent with Darcy's Law, infiltration rates varied with depth (or head) of water in the rain gardens. To determine if infiltration rates were changing over the duration of the study period, a fixed water depth was used in the computational process. This also provided a consistent basis for evaluating each rain garden. After cessation of rainfall, infiltration rates were estimated based on the rate of falling head in the rain garden from a depth of approximately $0.1 \mathrm{ft}$ to when the rain garden was no longer covered by water. Figure 6 shows an example of the estimation of infiltration rates in the sand rain gardens. In some cases, an estimate of infiltration rate was not possible because of additional influent prior to or during recession of pooled water in the rain garden. Estimates of infiltration rates were compared between soil types and vegetative species to show seasonal and temporal changes. Seasonal differences were determined by use of the nonparametric Mann-Whitney statistical test for two groups (Helsel and Hirsch, 1992). 


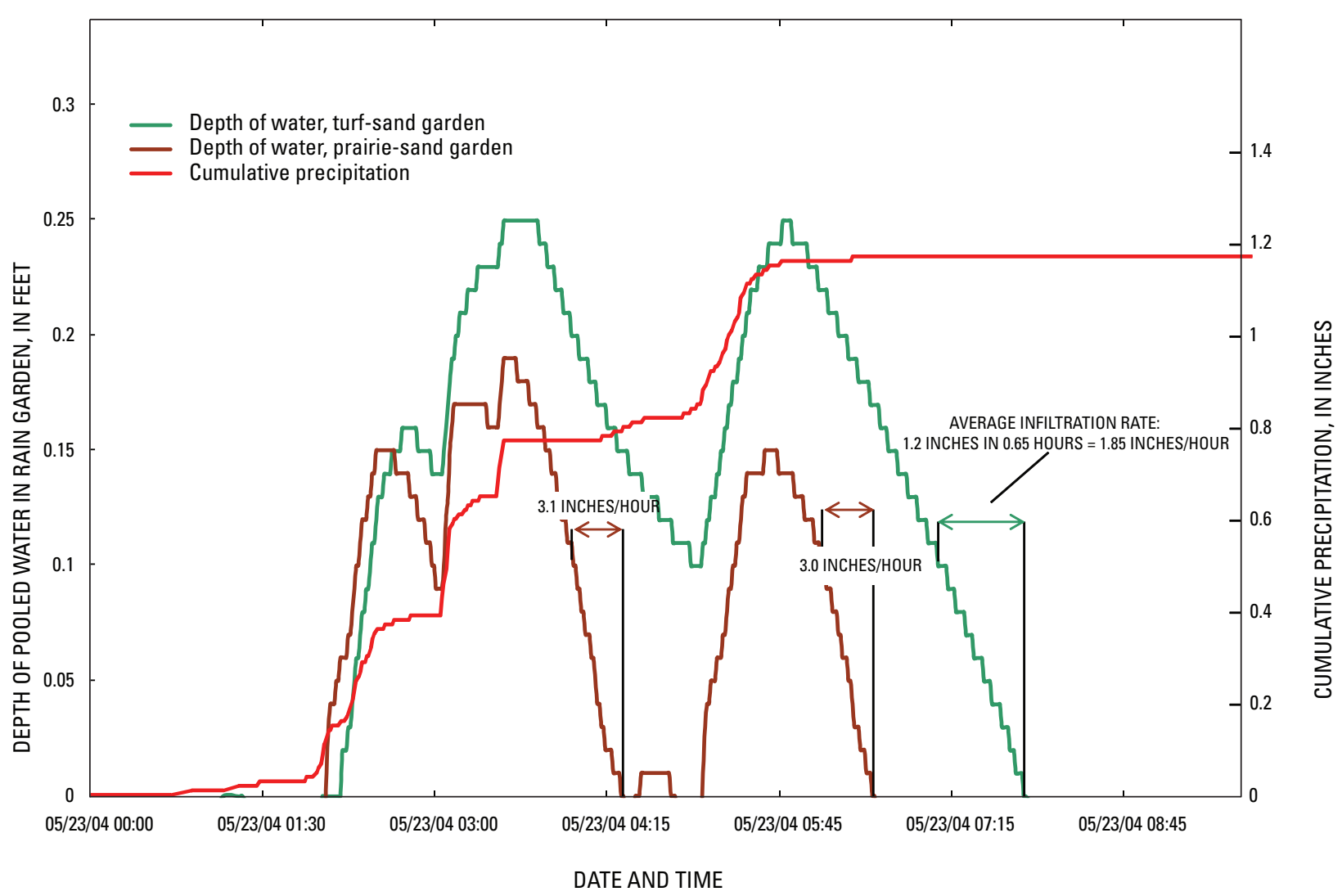

Figure 6. Example calculation of average infiltration rate using simplified falling-head technique in the sand rain gardens.

Limited sample populations precluded an evaluation of winter and fall infiltration rates in the prairie- and turf-sand and prairie-clay rain gardens. Therefore, use of the Mann-Whitney test was limited to a comparison of spring and summer infiltration rates. The infiltration rates for all four seasons in the turf-clay rain garden were compared by use of the nonparametric Kruskall-Wallis and Dunn's statistical tests for multiple groups (Dunn, 1964; Helsel and Hirsch, 1992).

\section{Characterization of Soils and Vegetation}

\section{Texture and Other Soil Properties}

Selection of each study location was based upon the presence of either sand or clay as the dominant soil texture. Prior to rain garden construction, a hand-powered soil auger was used to identify soil texture to a depth of approximately $1 \mathrm{ft}$ at each study location. In addition, regional soils maps were reviewed to verify soil classification at depth (Natural Resources Conservation Service, 2009). Infiltration rates were then determined at each location by use of a doublering infiltrometer. Finally, the resulting infiltration rates were then compared to published values typical for sand and clay soils (Rawls and others, 1998). In 2003, after construction of each rain garden was complete, a core was extracted from the prairie-clay and turf- and prairie-sand rain gardens to a depth of approximately $20 \mathrm{ft}$ by use of a Geoprobe to help provide a depth profile of texture changes. Additional soil cores were taken in 2008 at multiple locations in both the turf- and prairie-clay rain gardens to a depth of approximately $10 \mathrm{ft}$ to further characterize the substrate by minimizing the large amount of spatial variability in soil texture. All cores were taken during winter months when soils were frozen and less prone to compaction from heavy equipment.

\section{Soil Moisture}

Within each rain garden, volumetric soil-moisture profiles were measured by use of vertically oriented soilmoisture sensors (fig. 7). Soil moisture was measured at $20-\mathrm{cm}$ increments to a depth of $4 \mathrm{ft}$ below the rain garden. One sensor and its protective access tube were installed in each rain garden following methods described by the manufacturer (Sentek Party, Ltd., 1999). Proper installation of soil-moisture sensors and access tubes results in no air pockets along the length of the access tube and causes minimal disturbance of the adjacent soil profile (Graczyk and Greb, 2006). 


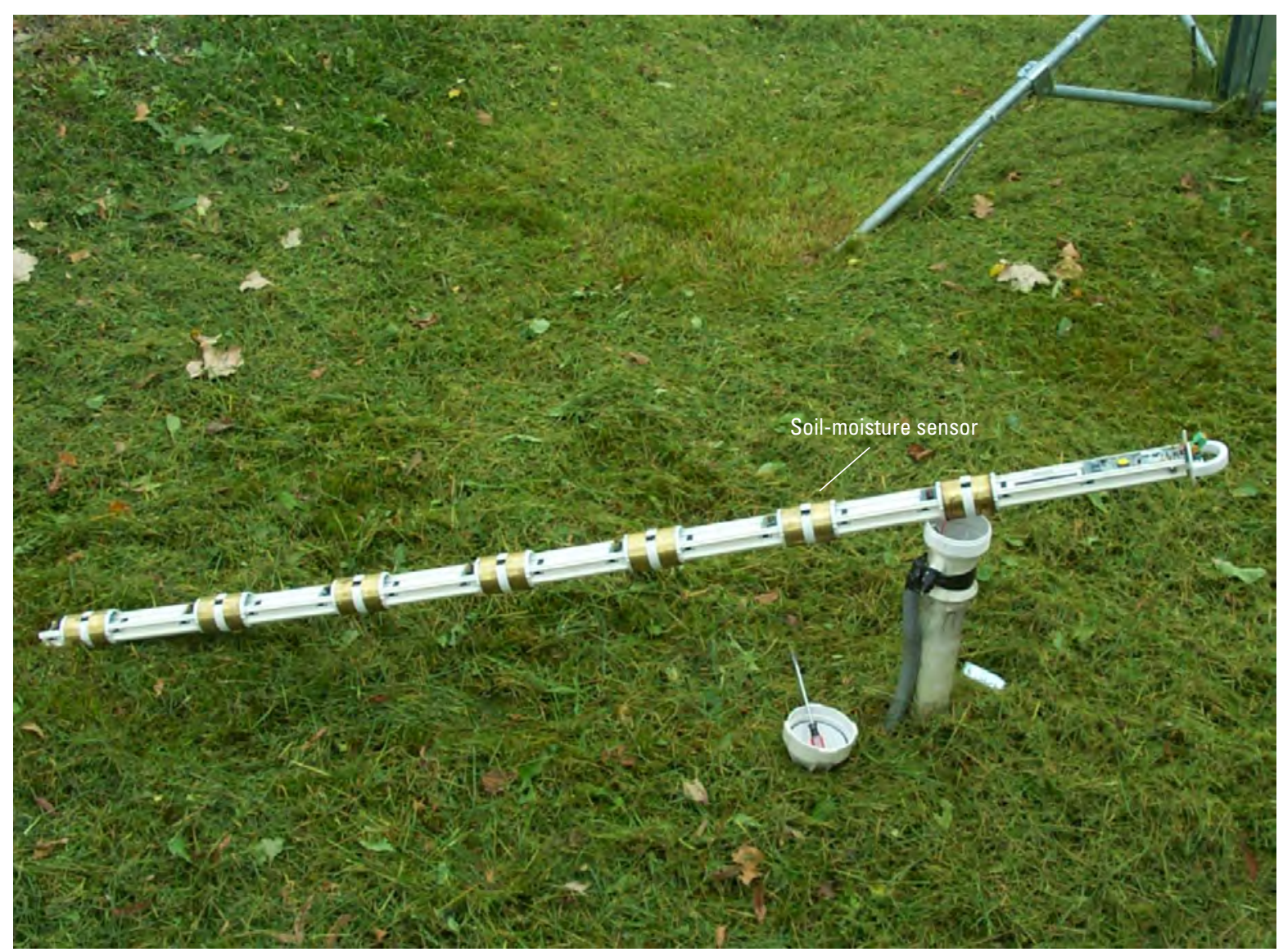

Figure 7. Soil-moisture sensors spaced at 20-centimeter intervals on soil probe. The soil probe is inserted vertically into the access tube.

Soil moisture was measured at $15 \mathrm{~cm}, 35 \mathrm{~cm}, 55 \mathrm{~cm}, 75 \mathrm{~cm}$, $95 \mathrm{~cm}$, and $115 \mathrm{~cm}$ below the land surface in the turf-clay, prairie-clay, and prairie-sand rain gardens. Soil moisture in the turf-sand rain garden was measured at $5 \mathrm{~cm}, 15 \mathrm{~cm}, 25$ $\mathrm{cm}, 35 \mathrm{~cm}$, and $45 \mathrm{~cm}$ below the land surface. Measurements of soil moisture were collected at 15 -min increments from October 2003 to January 2006 and 5-min increments from February 2006 to September 2008.

Each soil-moisture sensor was periodically calibrated by use of methods described by the manufacturer (Sentek Party, Ltd., 1999). Calibration was limited to 100 percent (water) and 0 percent (air) saturation. Each sensor can be calibrated to measure the absolute volumetric moisture content of a specific soil type if the physical properties of that soil are known across a range of moisture conditions. However, given the destructive nature of the calibration process to determine absolute soil moisture values, a generalized algorithm developed by the manufacturer to represent sands, loams, and clay loams, was used in this study. Therefore, on-site soilmoisture conditions were considered a relative, rather than absolute, value.

\section{Root Morphology}

In October 2008, a 4.25-ft-wide by 10 -ft-long observation trench was excavated through the approximate center of the prairie- and turf-clay rain gardens. The trench in the prairieclay rain garden was dug to a depth of $5 \mathrm{ft}$, while the turf-clay trench was excavated to only $4 \mathrm{ft}$ because of standing water at depth; no standing water was observed in the prairie-clay trench. These trenches provided profile walls that were used to describe the physical characteristics of each soil and quantify rooting dynamics within each rain garden. The south wall of each trench was prepared by hand for soil-profile descriptions, subsampling, and additional on-site root measurements; care was taken to avoid smearing of soil surfaces.

Soils were described according to standard protocol for field observation (Schoeneberger and others, 2002). Measurements included master and subordinate horizons, any changes in parent material, texture class, rooting depth, color, structure, and presence of mottling. After the soil profile descriptions were done, six discrete soil cores were extracted horizontally from the approximate midpoint of each horizon 
along the length of the trench by use of a 5.6-in ${ }^{3}$ cylinder driven into random locations along the trench wall, within each horizon, with a hammer-core sampler (Blake and Hartge, 2002). These samples were bagged and transported to the University of Wisconsin soils laboratory for measurements of bulk density and root morphology. An additional sample was taken with a hand trowel from each horizon for determination of soil texture.

Two of the six soil cores per horizon were used to quantify bulk density and soil organic matter (SOM). In the laboratory, the soil cores were dried at $105^{\circ} \mathrm{C}$ for 24 hours and then weighed. Bulk density was then calculated to the nearest $0.01 \mathrm{~g}$. Soil textures were determined by use of a hydrometer on samples pretreated with Calgon $\odot$ solution (Gee and Or, 2002). This analysis was performed at $30^{\circ} \mathrm{C}$ on samples from each horizon with the exception of horizons $\mathrm{O}$ and $\mathrm{A}$, due to the variable proportions of organics in those samples. Soil organic-matter contents were determined by loss on ignition, by use of $10 \mathrm{~g}$ of oven-dried soil heated at $550^{\circ} \mathrm{C}$ for $3 \mathrm{hr}$ in an Isotemp muffle furnace (Heiri and others, 2001).

Root dynamics were quantified in the lab from the remaining four core samples per horizon. Calculations of root length density (RLD), specific root length (SRL), root dry mass, and total length were done for each horizon. Each core was first soaked in distilled water for $48 \mathrm{hr}$, at which time the cores began to naturally disperse. The cores were then lightly agitated by hand to liberate the roots from the soil. All visible roots were extracted from the soil slurry on a $0.05-\mathrm{mm}$ soil sieve and cleaned with distilled water. The soil slurry was run through the sieving process a second time to ensure all roots were extracted from the core samples, and the roots were then patted dry on a paper towel. Next, the length of each root was measured. Last, the roots were dried at $70^{\circ} \mathrm{C}$ for $48 \mathrm{hr}$ in a convection oven before determination of dry weight.

\section{Comparison of Rain Gardens}

Hydrologic, soil, and vegetation characteristics were compared for the turf-clay, prairie-clay, turf-sand, and prairie-sand rain gardens from December 2003 to September 2008. During the 5-year monitoring period, the sand and clay gardens received runoff from more than 380 and 275 precipitation and snowmelt events, respectively (appendix tables 1-1 and 1-2). Measurements of runoff volume (both influent and effluent), precipitation, and reference evapotranspiration were used to determine the water balance for each rain garden, which, in turn, was used to estimate recharge. Water depth in each rain garden was measured to estimate infiltration rates, which were then compared to determine differences between vegetative species and soil type as well as seasonal and temporal trends.

\section{Soil Properties}

\section{Sand Site}

Figure 8 shows a cross section of surficial deposits based on the turf- and prairie-sand rain garden cores to a depth of $20 \mathrm{ft}$. The upper $4 \mathrm{ft}$ of soil in the prairie rain garden generally contained a greater amount of clay than the turf rain garden and was described as a loam to clay loam rather than a sandy loam. A thin clay layer was found in the prairie rain garden core at a depth of approximately $4.5 \mathrm{ft}$. This same clay layer was not found in the turf rain garden. Both gardens had sandy loam interspersed with occasional layers of clay loam below $5 \mathrm{ft}$. The upper $4 \mathrm{ft}$ of soil in the prairie rain garden showed most sediments to be classified as sandy loam with some gravel (fig. 8). The dissimilarity between soil profiles may be due, in part, to rain garden construction practices. Because the turf rain garden was located on a hill slope, a greater amount of material had to be excavated to achieve a level surface. This likely removed some of the surficial deposits that were found in the prairie rain garden. A level surface was more easily achieved with minimal excavation in the prairie rain garden. The elevation of the turf grass rain garden (postconstruction) was $0.77 \mathrm{ft}$ lower than that of the prairie rain garden.

Craig (2007) investigated soil and botanical characteristics of both the turf- and prairie-sand rain gardens and their relation with microbial community composition. The results were then compared to those determined from 50 additional rain gardens and lawns surveyed around Dane County, Wis., and are presented in table 2. The average soil composition from three test plots in the turf-sand rain garden had a higher percentage of organic matter than other surveyed lawns in Dane County. Similarly, porosity was higher in the rain gardens than in Dane County lawns, and this may have been a function of the higher sand content and lower bulk density in the rain gardens than in the Dane County lawns (table 2).

\section{Clay Site}

Figure 9 shows a cross section of two cores from the clay rain gardens. The prairie and turf cores were taken in 2003 and 2008, respectively. The turf- and prairie-clay rain gardens had variable thicknesses of sand, sand loam, clay, and silt clay deposits. The uppermost limiting clay layer was generally at shallower depths in the turf rain garden, at approximately $1.5 \mathrm{ft}$ below the soil surface, compared with approximately $3.0 \mathrm{ft}$ below the soil surface in the prairie rain garden. A continuous clay layer of variable thickness was distributed across both rain gardens at a depth of $3 \mathrm{ft}$. The upper $4 \mathrm{ft}$ of soil in the turf-clay rain garden showed most sediments to be classified as sandy clay, clay loam, and clay with some fine layers of sand and gravel (fig. 9). 


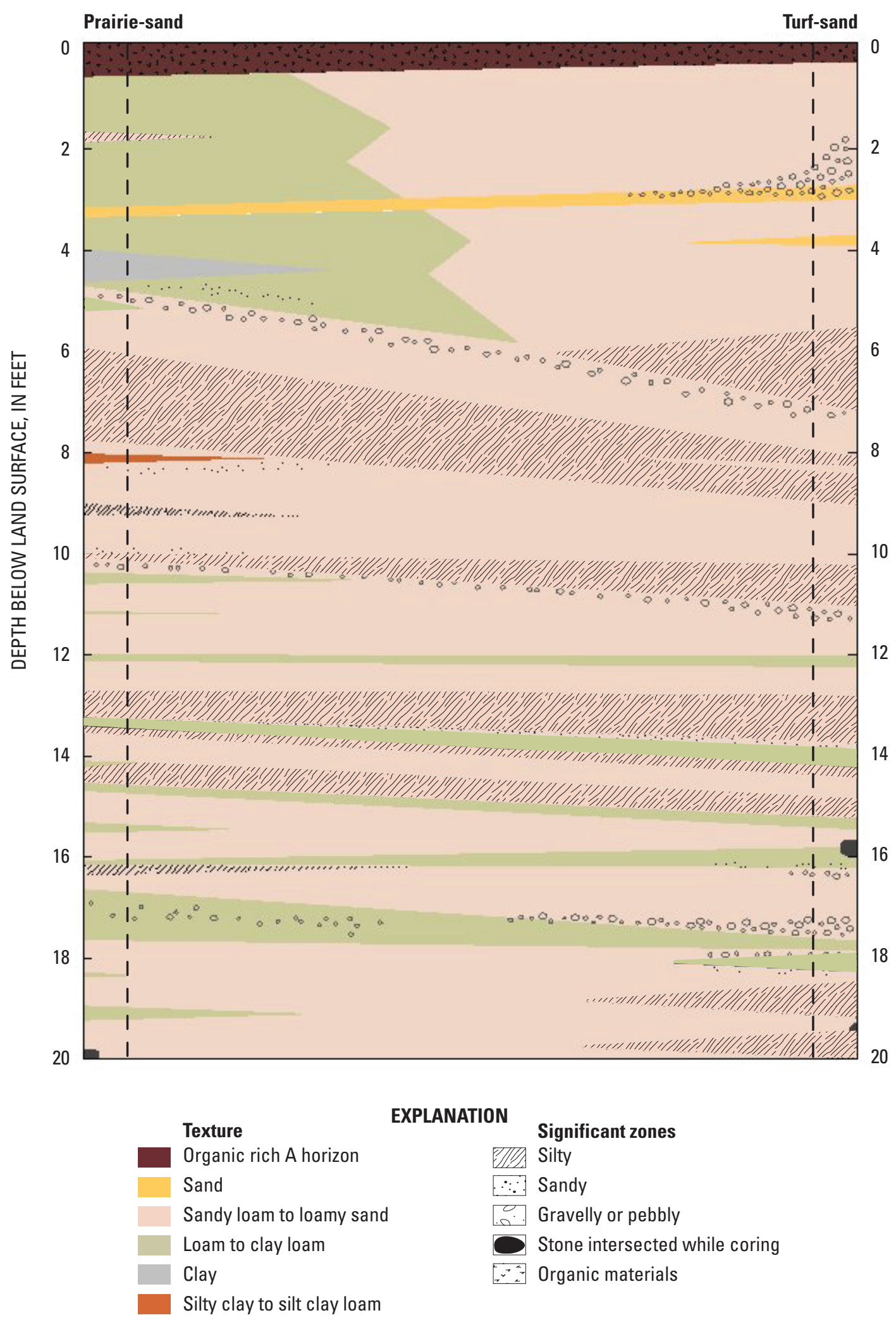

Figure 8. Cross section of soils and subsurface deposits between the turf and prairie rain gardens in sand. 
Prairie-clay

Turf-clay

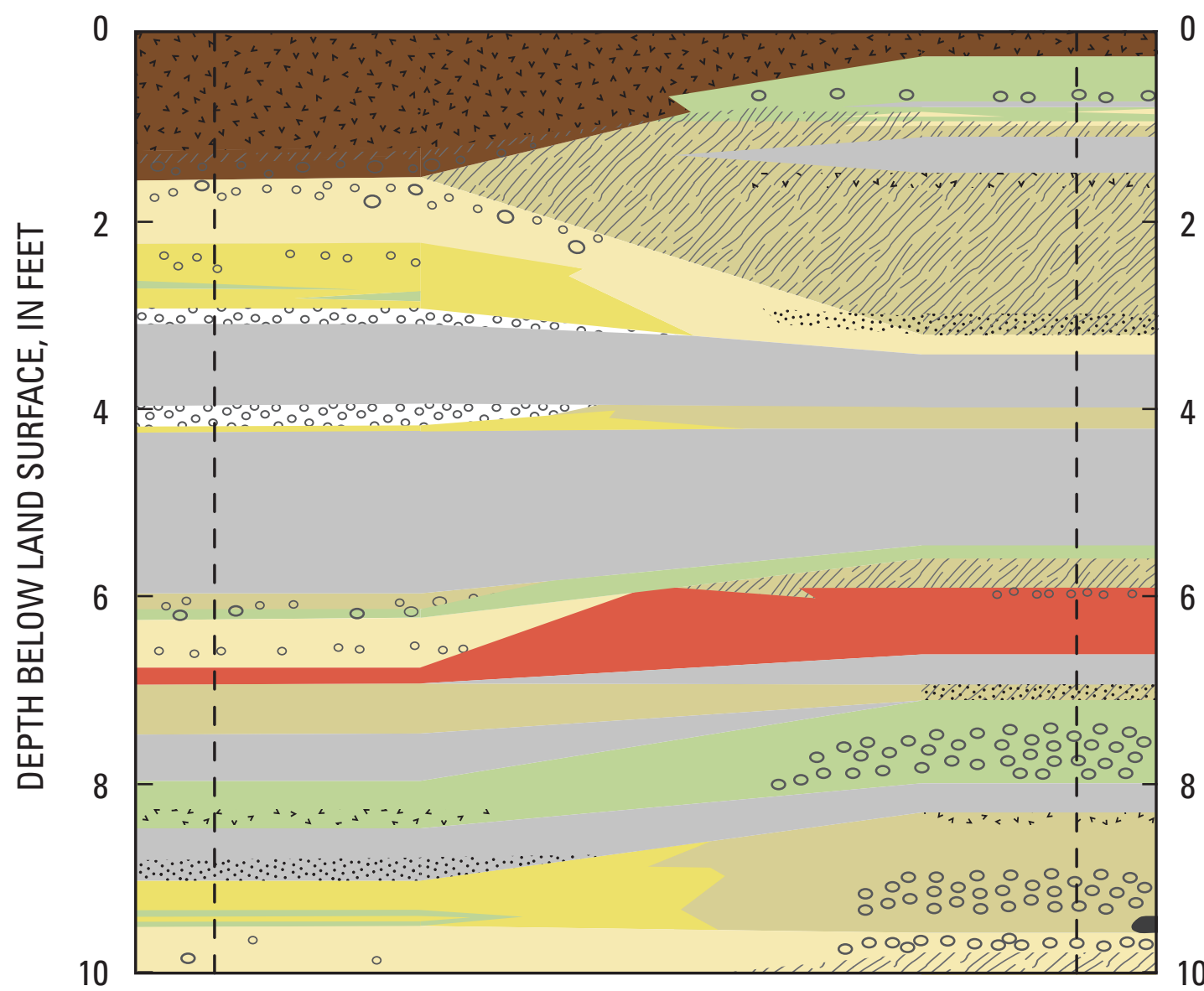

\section{EXPLANATION}

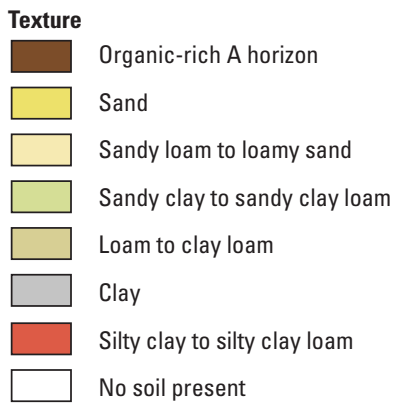

Significant Zones

ZIय Silty

Sandy

57 Organic materials

워 $\because$ Gravelly or pebbly

$\Longrightarrow$ Stone intersected while coring

Figure 9. Cross section of soils and subsurface deposits between the turf and prairie rain gardens in clay. 
Similar to the sand rain gardens, soil and botanical characteristics were examined in the clay rain gardens, and their characteristic were then compared to those from 50 additional rain garden and lawn surveys around Dane County, Wis. (Craig, 2007). The results are presented in table 2. The average soil composition from three test plots in the prairie-clay rain garden had a higher percentage of organic matter than surveyed lawns in Dane County. Similarly, porosity was higher the prairie- and turf-clay rain gardens than in other Dane County rain gardens; this may have been a function of the high sand content and low bulk density in the prairie- and turf-clay rain gardens than in the Dance County rain gardens (table 2).

\section{Water Influent and Effluent}

The main sources of influent to the rain gardens are rainfall and snowmelt runoff from the roof surfaces and rainfall falling directly onto the gardens. The water equivalent for snow falling directly over the rain garden was not included in the computation of influent, because actual snow depths were not recorded at the field site. During the 5-year monitoring period, the annual precipitation ranged from 24 percent below the 30-year normal of 32.95 in. in 2005 to 35 percent above normal in 2008 (fig. 10). Monitored storms during the period ranged in precipitation depth from less than $0.05 \mathrm{in}$., the amount typically required for generating rooftop runoff, to $4.0 \mathrm{in}$. Sixty-min precipitation intensities ranged from 0.01 to $1.29 \mathrm{in} / \mathrm{hr}$.

\section{Sand Site}

Annual rainfall-runoff volumes into the turf-sand and prairie-sand rain gardens were nearly equal during each study year and showed a difference in influent of 5 percent or less for all years (table 3). In general, the prairie-sand rain garden received slightly more influent volume than the turf-sand rain garden. Some of the added volume can be attributed to preferential rainfall patterns as well as a disproportionate amount of snowmelt to the prairie-sand rain garden owing to the roof's orientation to the sun. Annual influent volumes were slightly less in water year 2004 than in 2007 despite having a greater annual precipitation depth in 2004. Much of this discrepancy is due to the estimated water equivalency

Table 2. Summary of physical and botanical characteristics identified in the turf-grass and prairie rain gardens in a sand soil and in a clay soil.

[Soil characteristics represent average values from three test plots per rain garden. Comparison of features in the study rain gardens was made to other rain gardens surveyed around Dane County, Wis. --, data not available; nmol, nanomole]

\begin{tabular}{|c|c|c|c|c|c|c|}
\hline \multirow[b]{2}{*}{ Physical and biological variables } & \multicolumn{2}{|c|}{ Sand site } & \multicolumn{2}{|c|}{ Clay site } & \multicolumn{2}{|c|}{ Dane County ${ }^{1}$} \\
\hline & Prairie & Turf grass & Prairie & Turf grass & Rain garden & Lawn \\
\hline Age of rain garden, in years & 3 & 3 & 3 & 3 & 2 & -- \\
\hline Area of rain garden, in square feet & 92.5 & 85.5 & 403 & 354 & 280 & -- \\
\hline Organic matter, in percent & 14.3 & 18.5 & 17.6 & 26.4 & 7.5 & 5.4 \\
\hline Bulk density, in grams per cubic centimeter & 0.83 & 0.59 & 0.61 & 0.56 & 1.1 & 1.2 \\
\hline Pore space, in percent & 69 & 76 & 77 & 80 & 61 & 56 \\
\hline Water content, in percent & 21 & 23 & 22 & 37 & 26 & 24 \\
\hline Soil air, in percent & 48 & 52 & 55 & 43 & 35 & 33 \\
\hline $\mathrm{pH}$ & 7.2 & 7.0 & 7.1 & 7.1 & 6.2 & 6.6 \\
\hline \multicolumn{7}{|l|}{ Particle size distribution, in percent } \\
\hline Sand & 45 & 59 & 50 & 47 & 37 & 35 \\
\hline Clay & 16 & 15 & 14 & 14 & 16 & 16 \\
\hline Silt & 39 & 26 & 37 & 39 & 47 & 49 \\
\hline Soil texture & Loam & Sandy loam & Loam & Loam & Loam & Loam \\
\hline Vegetation richness, in number of plant species & 29 & 10 & 39 & 21 & 34 & -- \\
\hline Vegetation cover, in percent & $60-70$ & 85 & 100 & 100 & 63 & -- \\
\hline Total microbial biomass, in nmol of lipids per gram of soil & 199 & 209 & 209 & 194 & 174 & 131 \\
\hline Relative abundance of bacteria, in mole percent & 23 & 29 & 24 & 31 & 25 & 28 \\
\hline Relative abundance of fungi, in mole percent & 20 & 9 & 21 & 10 & 20 & 17 \\
\hline
\end{tabular}

\footnotetext{
${ }^{1}$ Average value of 50 gardens in Dane County, Wis. (Craig, 2007).
} 
Table 3. Summary of influent and effluent volume measured in the turf-grass and prairie rain gardens at the sand and clay soil study sites, water years 2004-08, Madison, Wis.

[--, data not available; values represent volumes into and out of rain garden from roof and direct precipitation; they include snowmelt for runoff but do not include water equivalent for snow falling directly on rain garden. Therefore, the volumes in this table and those presented in table 4 will be different because table 4 includes estimates of water equivalent for snow using available NOAA data]

\begin{tabular}{|c|c|c|c|c|c|c|c|c|c|c|}
\hline \multirow[b]{3}{*}{ Rain Garden } & \multicolumn{10}{|c|}{$\begin{array}{c}\text { Volume } \\
\text { (cubic feet) }\end{array}$} \\
\hline & \multicolumn{5}{|c|}{ Influent } & \multicolumn{5}{|c|}{ Effluent } \\
\hline & 2004 & 2005 & 2006 & 2007 & 2008 & 2004 & 2005 & 2006 & 2007 & 2008 \\
\hline Turf-sand & 1,279 & 749 & 1,142 & 1,341 & $2,157^{1}$ & 0 & 0 & 0 & 0 & $11^{1}$ \\
\hline Prairie-sand & 1,275 & 764 & 1,206 & 1,354 & -- & 0 & 0 & 0 & 0 & -- \\
\hline Percent difference & 0 & -2 & -5 & -1 & -- & 0 & 0 & 0 & 0 & -- \\
\hline Turf-clay & 5,436 & 2,923 & 4,247 & 5,198 & -- & 191 & 35 & 10 & 12 & -- \\
\hline Prairie-clay & 5,859 & 2,423 & 3,608 & 4,437 & $8,331^{1}$ & 0 & 0 & 0 & 0 & $138^{1}$ \\
\hline Percent difference & $-7 \%$ & $21 \%$ & $18 \%$ & $17 \%$ & -- & $100 \%$ & $100 \%$ & $100 \%$ & $100 \%$ & -- \\
\hline
\end{tabular}

${ }^{1}$ In water year 2008, all roof runoff was directed to the turf-sand and prairie-clay rain gardens. This doubled the ratio of contributing to receiving area to 10 to 1 and 8 to 1 , respectively.

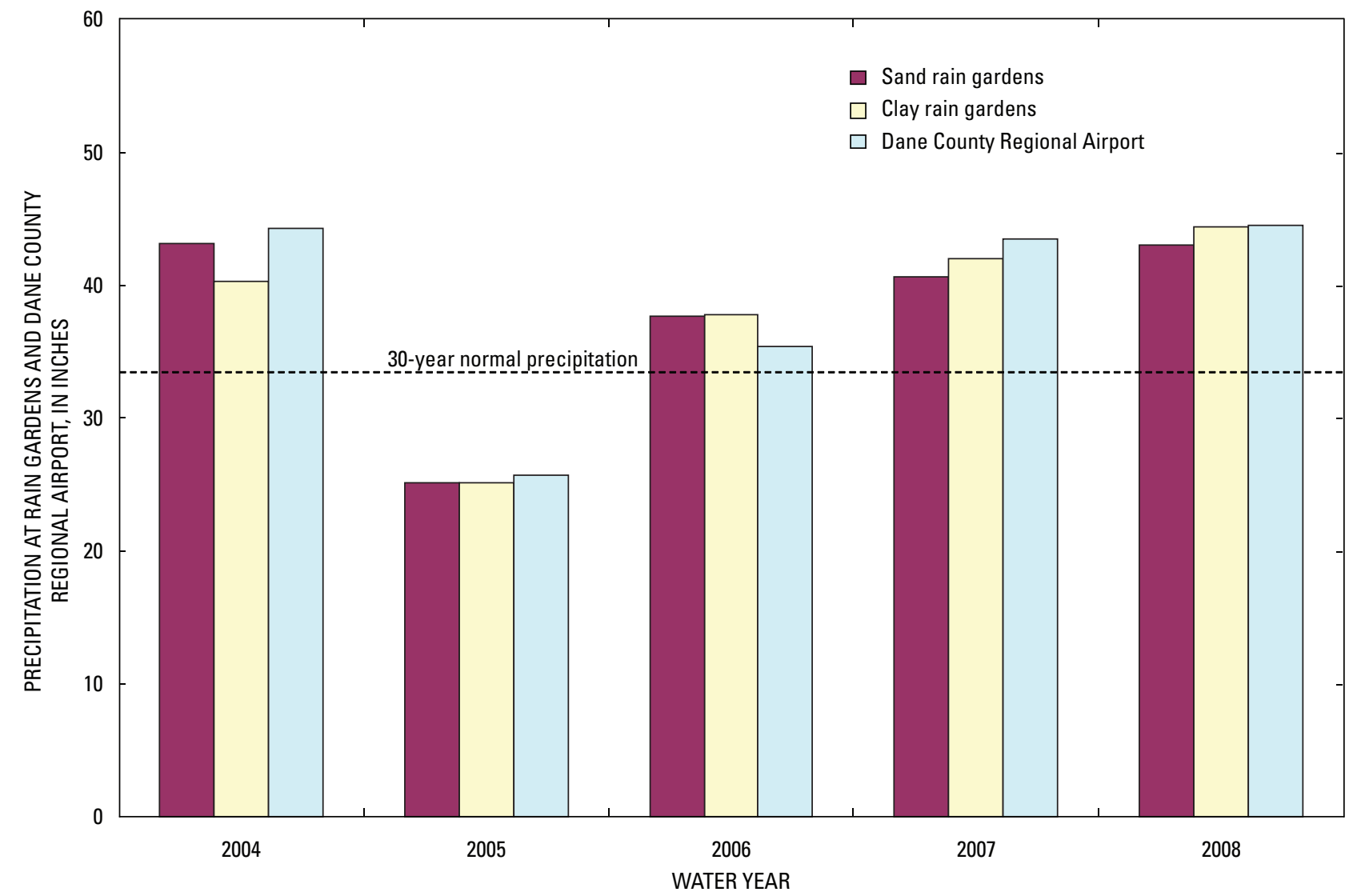

Figure 10. Precipitation totals at the clay and sand rain gardens study sites during each study year. The 30-year (1971-2000) normal precipitation line shown above is based on precipitation measured at the Dane County Regional Airport in Madison, Wis., approximately 10 miles from the study area. 


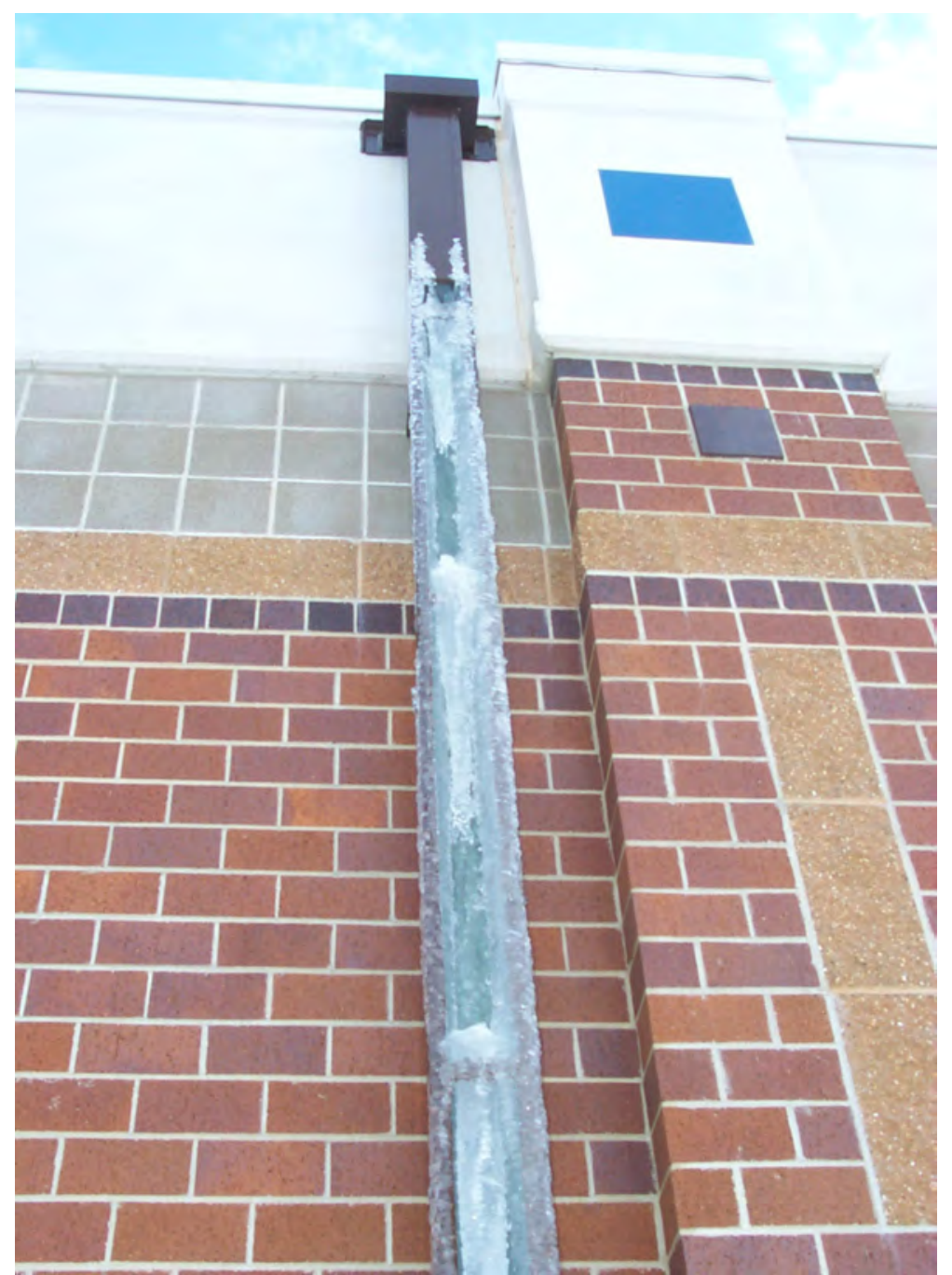

Figure 11. Accumulation of ice in downspouts draining rooftop runoff at the clay study site.

of snowmelt during winter months. If the months of the year for which precipitation was estimated by use of data from the NOAA weather station at the Dane County Regional Airport in Madison, Wis. (December through March) are excluded, then total precipitation in water year 2007 was, in fact, greater than in 2004.

There were no monitored precipitation events during the initial phase (2004-07) of the study that exceeded the storage capacity of either the turf-sand or prairie-sand rain gardens; therefore, all runoff was infiltrated and stored, lost to the atmosphere through evapotranspiration, or recharged. In water year 2008, all runoff was directed to only the turf-sand rain garden. Despite this doubling of the contributing drainage area, only a single event on June 8, 2008, produced measurable effluent in the turf-sand rain garden (table 3 ). Some events prior to June 8 had similar precipitation depths and intensities, but they did not result in effluent discharge. The interval between these storms was long enough to allow soils to drain. Therefore, the effluent discharge that resulted from the June 8 event was likely due to a combination of not only high precipitation intensity and depth but also saturated soil conditions from previous events. Rainfall on consecutive days from June 5 through June 8 totaled more than 5 inches.

\section{Clay Site}

Annual runoff volumes into the turf-clay rain garden were approximately 20 percent greater than the prairie-clay rain garden for all but 1 study year (table 3). It is unclear why more rooftop runoff was measured in the turf-clay rain garden. One possible explanation is the buildup of precipitation due to prevailing winds. Although each downspout drained an equal amount of rooftop area, prevailing westerly winds had the potential to push some water from the roof area draining to the prairie-clay rain garden over to the roof area draining to the turfclay rain garden. Differences in measured annual influent volumes could also be attributed to the downspout design. Each downspout had an open face that allowed runoff to occasionally escape the channel walls. This small amount of runoff was not collected or measured by the H-flumes and, thus, was unaccounted for. This phenomenon was more pronounced during winter months when the downspout channel would fill with ice (fig. 11) than during other seasons. Much of the water from melting ice was not contained within the downspout channel walls. Although each downspout had this design limitation, it may have been more pronounced in the downspout draining to the prairie-clay rain garden.

The turf-clay rain garden had one or more precipitation or snowmelt events or both resulting in a measureable volume of runoff leaving the rain garden during each study year (table 3 ). In most instances, effluent volume was a result of high precipitation intensity or depth or both. Nearly one-half of all effluent volume measured from the turf-clay rain garden was the result of two storm events in May 2004 that produced 4.7 in. of rain within 48 hours (appendix table 1-2). There were no monitored events during the initial phase (2004-07) of the study that exceeded the storage capacity of the prairie-clay rain garden; therefore, all runoff was infiltrated and stored, lost to the atmosphere through evapotranspiration, or recharged. During water year 2008 , all runoff was directed to only the prairieclay rain garden, thereby doubling the contributing drainage area. All effluent volume measured during this period was a result of four precipitation events, each with precipitation depths in excess of 2.5 in. (appendix table 1-2). 


\section{Evapotranspiration}

In general, reference evapotranspiration followed a seasonal pattern of the highest monthly totals occurring during the warmer summer months of June and July, followed by gradually decreasing values with the onset of plant senescence in late fall (fig. 12). Because the turf grass evaluated as part of this study closely resembled that of a reference surface, estimated evapotranspiration values were only slightly modified (Allen and others, 1998). Several species identified in the prairie rain gardens were given a landscape coefficient ranging from "low" to "high." Regardless of soil type, resulting correction coefficients for prairie vegetation were lower than those for turf grass; therefore, estimates of evapotranspiration were also lower.

Annual evapotranspiration for turf grass ranged from 21 to $26 \mathrm{in}$. in the sand and clay rain gardens for water years 2004 and 2005, respectively (table 4). This accounts for more than one-half of direct annual precipitation. Evapotranspiration was greater than direct precipitation in 2005, which is a result of below-normal precipitation. Steuer and Hunt (2001) reported similar average annual evapotranspiration amounts (23.9 in) for the watershed in which this study was located, based on hydrologic model simulations from 1993 to 1998. Because the contributing drainage area to each rain garden was approximately five times greater than the receiving area, the percentage of turf-grass evapotranspiration, when compared to direct precipitation plus influent, ranged from a low of 9 in 2004 to a high of 21 in 2005 for the clay rain garden, and from a low of 11 in 2004 to a high of 25 in 2005 for the sand clay garden (table 4). The percentage of evapotranspiration was reduced to 7 percent in water year 2008, when the contributing drainage area to the turf-sand rain garden was doubled to approximately 10 times the receiving area (table 4).

Differences in leaf anatomy, stomatal characteristics, density, and aerodynamic properties of vegetation can cause differences in evapotranspiration (Allen and others, 1998). Microclimate can also be important. Table 5 lists several species of vegetation identified by Craig (2007) in the prairie rain gardens and presents a correction coefficient to reference evapotranspiration based on species, density, and microclimate. Bare ground was the largest percentage of ground cover (or lack thereof) in the prairie-sand rain garden. Water may be lost from soil evaporation when ground shading is less than 100 percent. Consequently, the reference evapotranspiration rate for bare soils was increased by 10 to 20 percent (Costello and others, 2000). The weighted-average landscape coefficient, $\mathrm{K}_{\mathrm{L}}$, for all identified species ranged from 0.5 to 0.7 for the prairie-sand garden to 0.2 to 0.5 for the prairie-clay garden. These values agree with similar landscape coefficients for prairie vegetation recorded by Pitt and others (2008). By use of this range of landscape coefficients, the annual evapotranspiration for the prairie rain gardens was estimated to range from 2 percent in 2004 to 12 percent in 2005 for the clay rain gardens, and from 6 percent in 2004 to 19 percent in 2005 for the sand rain gardens (table 4). The percentage of evapotranspiration in the prairie-clay rain garden decreased in water year 2008, ranging from 1 to 4 percent, when the contributing drainage area was doubled to approximately eight times the receiving area (table 4).

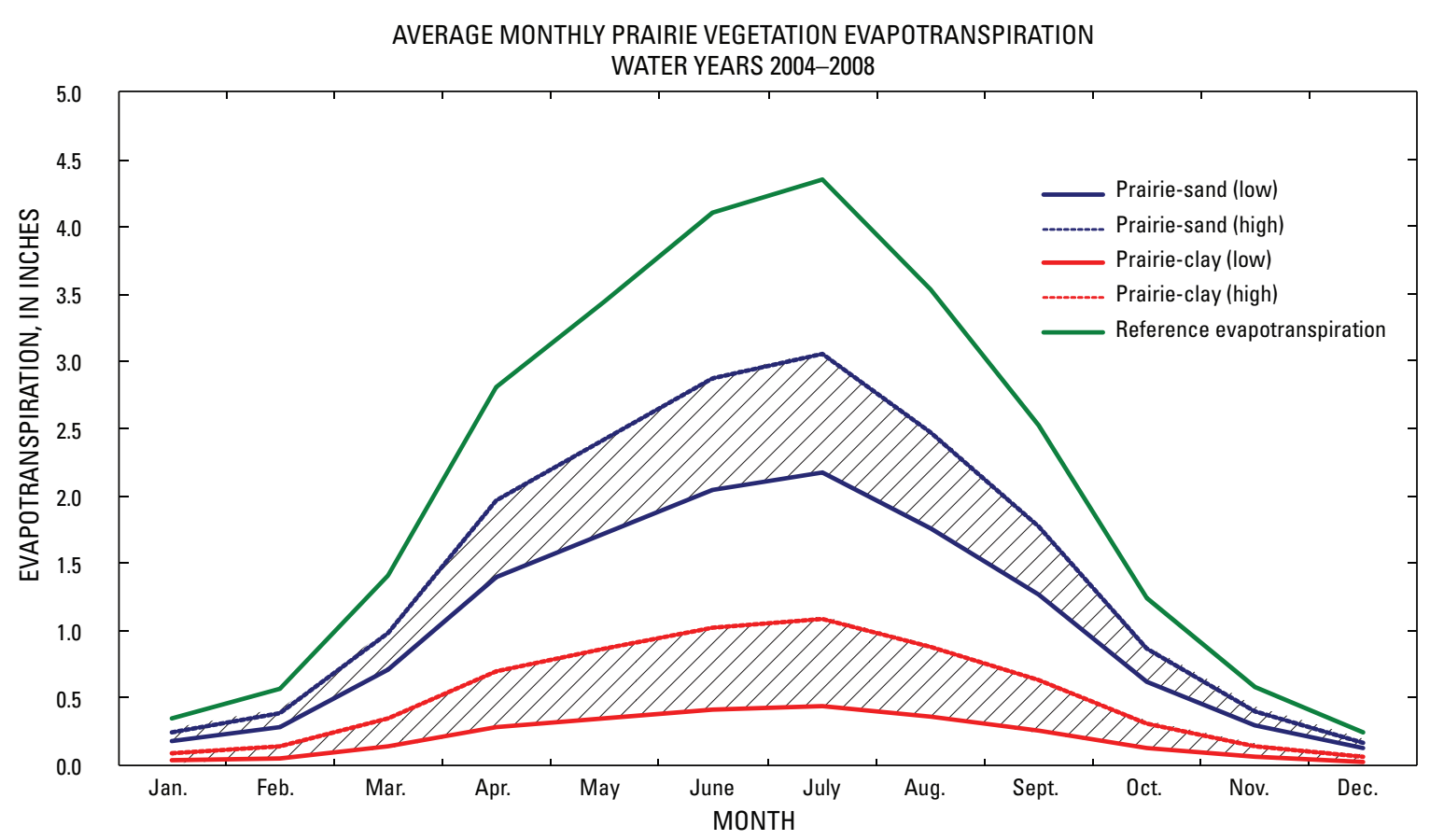

Figure 12. Annual distribution of reference evapotranspiration and range of estimated evapotranspiration for prairie rain gardens at the sand and clay study sites. 


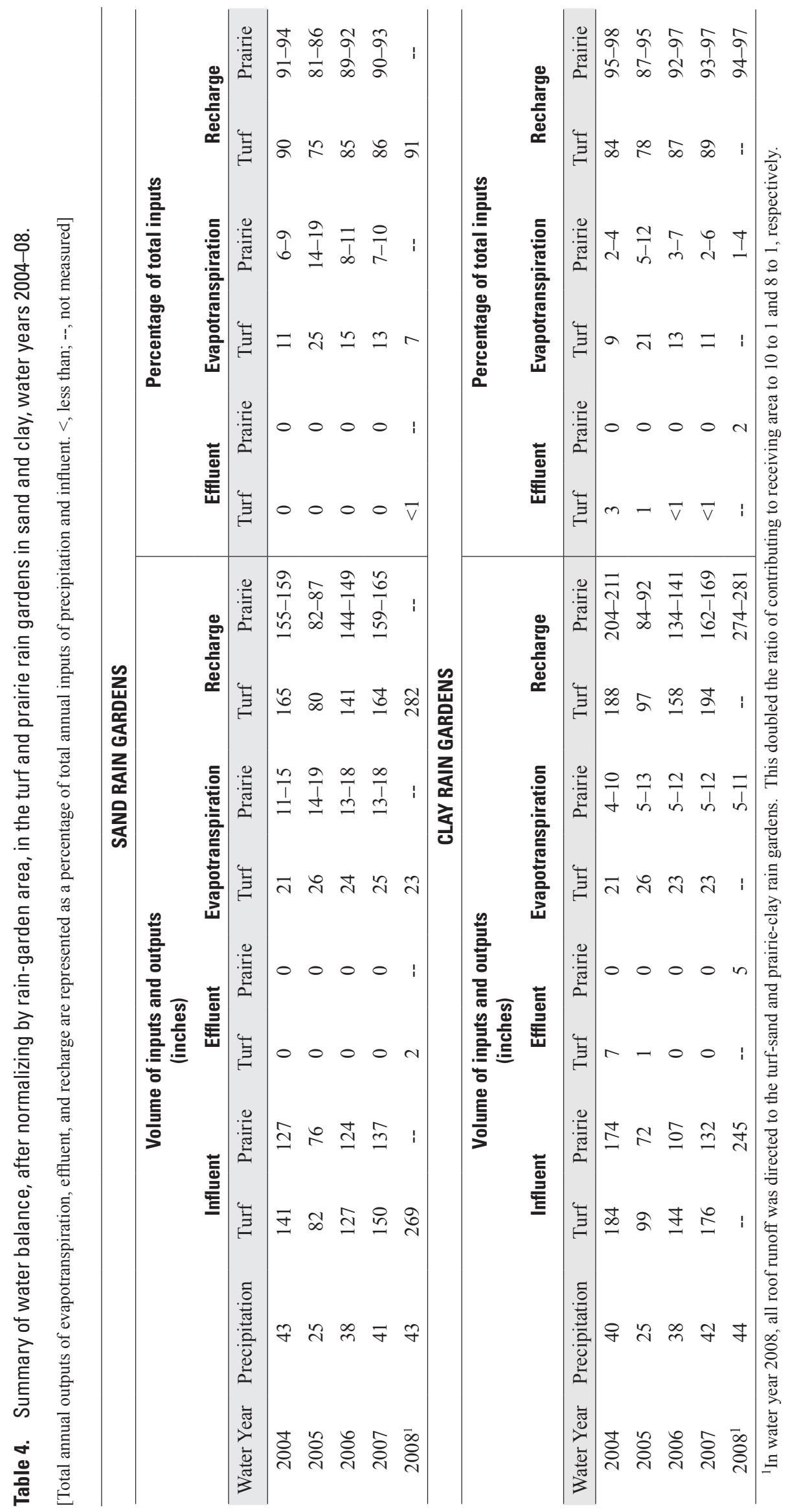


Table 5. Summary of vegetative species identified by Craig (2007) in the turf-grass and prairie rain gardens in sand and clay and computed landscape coefficient for estimating evapotranspiration (Costello and others, 2000).

[--, data not available; $\mathrm{K}_{\mathrm{s}}$, species factor; $\mathrm{K}_{\mathrm{d}}$, density factor; $\mathrm{K}_{\mathrm{mc}}$, microclimate factor; $\mathrm{K}_{\mathrm{L}}$, landscape coefficient]

\begin{tabular}{|c|c|c|c|c|c|c|c|c|c|c|c|c|}
\hline \multicolumn{13}{|c|}{ SAND SITE } \\
\hline \multirow{2}{*}{$\begin{array}{l}\text { Plant species } \\
\text { in plots }\end{array}$} & \multicolumn{4}{|c|}{ Percent cover } & \multicolumn{4}{|c|}{ Low range } & \multicolumn{4}{|c|}{ High range } \\
\hline & Plot 1 & Plot 2 & Plot 3 & $\begin{array}{l}\text { Weighted } \\
\text { average }\end{array}$ & $\mathrm{K}_{\mathrm{s}}$ & $K_{d}$ & $\mathrm{~K}_{\mathrm{mc}}$ & $\mathrm{K}_{\mathrm{L}}$ & $K_{s}$ & $K_{d}$ & $\mathrm{~K}_{\mathrm{mc}}$ & $K_{L}$ \\
\hline Bare ground & 64 & 16 & 32 & 36 & -- & -- & -- & 1.1 & -- & -- & -- & 1.2 \\
\hline Carex vulpinoidea & 8 & 1 & .5 & 2 & 0.4 & 0.5 & 0.5 & .1 & 0.6 & 0.9 & 0.9 & .5 \\
\hline Hierochloe odorata & 8 & 0 & 0 & 2 & .4 & .5 & .5 & .1 & .6 & .9 & .9 & .5 \\
\hline $\begin{array}{l}\text { Schizachyrium } \\
\text { scoparium }\end{array}$ & 0 & 4 & 8 & 3 & .4 & .5 & .5 & .1 & .6 & .9 & .9 & .5 \\
\hline $\begin{array}{l}\text { Tradescantia } \\
\text { ohiensis }\end{array}$ & 4 & 2 & 0 & 1 & .4 & .5 & .5 & .1 & .6 & .9 & .9 & .5 \\
\hline $\begin{array}{c}\text { Penstemon } \\
\text { digitalis }\end{array}$ & 16 & 16 & 4 & 11 & .4 & .5 & .5 & .1 & .6 & .9 & .9 & .5 \\
\hline Monarda fistulosa & 4 & 64 & 16 & 27 & .4 & .5 & .5 & .1 & .6 & .9 & .9 & .5 \\
\hline $\begin{array}{l}\text { Rudbeckia } \\
\text { subtomentosa }\end{array}$ & 8 & 0 & 8 & 4 & .4 & .5 & .5 & .1 & .6 & .9 & .9 & .5 \\
\hline $\begin{array}{l}\text { Eupatorium } \\
\text { perfoliatum }\end{array}$ & 0 & 8 & 0 & 1 & .4 & .5 & .5 & .1 & .6 & .9 & .9 & .5 \\
\hline Cirsium arvense & 1 & 0 & 4 & 1 & .4 & .5 & .5 & .1 & .6 & .9 & .9 & .5 \\
\hline Lactuca scariola & 0 & 2 & 8 & 2 & .4 & .5 & .5 & .1 & .6 & .9 & .9 & .5 \\
\hline $\begin{array}{l}\text { Glechoma } \\
\text { heterophylla }\end{array}$ & 0 & 4 & 32 & 11 & .1 & .5 & .5 & .0 & .3 & .9 & .9 & .2 \\
\hline \multicolumn{13}{|c|}{ CLAY SITE } \\
\hline \multirow{2}{*}{$\begin{array}{l}\text { Plant species } \\
\text { in plots }\end{array}$} & \multicolumn{4}{|c|}{ Percent cover } & \multicolumn{4}{|c|}{ Low range } & \multicolumn{4}{|c|}{ High range } \\
\hline & Plot 1 & Plot 2 & Plot 3 & $\begin{array}{l}\text { Weighted } \\
\text { average }\end{array}$ & $K_{s}$ & $K_{d}$ & $\mathrm{~K}_{\mathrm{mc}}$ & $\mathrm{K}_{\mathrm{L}}$ & $\mathrm{K}_{\mathrm{s}}$ & $K_{d}$ & $\mathrm{~K}_{\mathrm{mc}}$ & $\mathrm{K}_{\mathrm{L}}$ \\
\hline Bare ground & 0.5 & 0.5 & 1 & 1 & -- & -- & 0.5 & 1.1 & -- & -- & 0.9 & 1.2 \\
\hline Panicum virgatum & 16 & 0 & 0 & 5 & 0.4 & 1.1 & .5 & .2 & 0.6 & 1.3 & .9 & .7 \\
\hline Iris versicolor & 0 & 0 & 16 & 5 & .1 & 1.1 & .5 & .1 & .3 & 1.3 & .9 & .4 \\
\hline Carex lupilina & 16 & 0 & 16 & 10 & .4 & 1.1 & .5 & .2 & .6 & 1.3 & .9 & .7 \\
\hline Scirpus atrovirens & 0 & 8 & 0 & 3 & .7 & 1.1 & .5 & .4 & .9 & 1.3 & .9 & 1.1 \\
\hline $\begin{array}{l}\text { Rudbeckia } \\
\text { subtomentosa }\end{array}$ & 4 & 0 & 4 & 2 & .4 & 1.1 & .5 & .2 & .6 & 1.3 & .9 & .7 \\
\hline Physostegia virginica & 7 & 0 & 0 & 2 & .4 & 1.1 & .5 & .2 & .6 & 1.3 & .9 & .7 \\
\hline $\begin{array}{l}\text { Thalictrum } \\
\text { dasycarpum }\end{array}$ & .5 & .5 & 5 & 2 & .4 & 1.1 & .5 & .2 & .6 & 1.3 & .9 & .7 \\
\hline Helenium autumnale & 16 & 64 & 0 & 26 & .1 & 1.1 & .5 & .1 & .3 & 1.3 & .9 & .4 \\
\hline Aster novae-angliae & 4 & 2 & 0 & 2 & .4 & 1.1 & .5 & .2 & .6 & 1.3 & .9 & .7 \\
\hline $\begin{array}{l}\text { Lysimachia } \\
\text { quadriflora }\end{array}$ & 0 & 0 & 16 & 5 & .7 & 1.1 & .5 & .4 & .9 & 1.3 & .9 & 1.1 \\
\hline Poa pratensis & 32 & 0 & 8 & 13 & .4 & 1.1 & .5 & .2 & .6 & 1.3 & .9 & .7 \\
\hline $\begin{array}{l}\text { Erigeron } \\
\quad \text { philadelphicus }\end{array}$ & 0 & 0 & 64 & 21 & .1 & 1.1 & .5 & .1 & .3 & 1.3 & .9 & .4 \\
\hline Lactuca serriola & 1 & 2 & 0 & 1 & .4 & 1.1 & .5 & .2 & .6 & 1.3 & .9 & .7 \\
\hline Taraxacum officinale & 8 & 0 & 0 & 2 & .1 & 1.1 & .5 & .06 & .3 & 1.3 & .9 & .4 \\
\hline Chenopodium album & 0 & 0 & 4 & 1 & 0.4 & 1.1 & 0.5 & 0.2 & 0.6 & 1.3 & 0.9 & 0.7 \\
\hline
\end{tabular}




\section{Recharge, Infiltration, and Storage} formula:

Recharge was estimated by use of the water-balance

$$
\mathrm{R}=\mathrm{P}+\mathrm{V}_{\mathrm{i}}-\mathrm{V}_{\mathrm{o}}-\mathrm{ET}
$$

where

$$
\begin{array}{cl}
\mathrm{R} & \text { is recharge, in inches; } \\
\mathrm{P} & \text { is precipitation, in inches; } \\
\mathrm{V}_{\mathrm{i}} & \text { is the volume of runoff into the rain garden, } \\
& \text { in inches; } \\
\mathrm{V}_{\mathrm{o}} & \text { is the volume of runoff out of the rain garden, } \\
\text { in inches; and } & \text { is evapotranspiration, in inches. }
\end{array}
$$

Table 4 shows the amount of water for each variable described in the formula above as well as the relative percentage of water outputs to inputs. For comparison, volumes in table 4 were normalized by rain-garden area. Rain gardens planted with prairie vegetation are expressed in terms of a range of low to high recharge to coincide with a similar range in evapotranspiration. At both the sand and clay study sites, the rain garden planted with turf grass received slightly more annual influent than the rain garden planted with prairie vegetation. Although more water was available for recharge in the turf-grass rain gardens, the overall percentage of annual recharge in the turf-grass rain gardens was slightly less than in the prairie rain gardens. This is largely attributable to a much smaller amount of evapotranspiration estimated for prairie species than for turf species. If rooftop runoff were equally distributed between the turf-grass and prairie-rain gardens, the difference in percent recharge between turf grass and prairie vegetation would become even greater.
Differences in annual recharge between the turf-grass and prairie-rain gardens in clay were slightly greater than the differences between those vegetative species in sand. The average difference between percent annual recharge in the turf grass and prairie rain gardens in clay was 7 percent compared to 4 percent in sand (using the lower estimate of annual percent recharge for the prairie rain gardens). Differences in vegetation may therefore have a more pronounced effect on recharge given similar soil structure.

In general, each rain garden, regardless of vegetation or soil type, was capable of storing and infiltrating most of the runoff during the 5-year study period. This might suggest that use of a specific vegetative species in a rain garden has no bearing on its overall performance. However, the robust design of the rain gardens tested in this study may have been the primary reason for their success. A simple calculation was done to characterize the approximate size of storm required to exceed the storage capacity of each rain garden. Assuming zero infiltration, the minimum depth of precipitation required to fill the turf- and prairie-clay rain gardens would be approximately 1.4 and 1.6 in, respectively. Both rain gardens in sand would require approximately $1.2 \mathrm{in}$. of precipitation. Total storm precipitation (excluding snowfall) exceeded these thresholds approximately 10 percent of the time over 4 years in both the clay and sand rain gardens (fig. 13). A rain garden construction by use of a 5-to-1 ratio of contributing to receiving area (4 to 1 for the prairie-clay rain garden) was, therefore, fully capable of retaining approximately 90 percent of all precipitation events. However, because the water-retaining capacity of a rain garden is both a function of above- and below-ground storage of runoff from a source area as well as simultaneous infiltration of runoff, the capacity to store runoff from a precipitation or snowmelt event or both is beyond that suggested by ponding depth alone. Because

Table 6. Comparison of observed and predicted precipitation events exceeding the storage capacity, both above- and belowground, in the turf- and prairie-clay rain gardens, April through November, water years 2004-07.

\begin{tabular}{lccccc}
\hline & \multicolumn{2}{c}{$\begin{array}{c}\text { Storage volume } \\
\text { (inches) }\end{array}$} & $\begin{array}{c}\text { Median infiltration } \\
\text { rate (inches/hour) }\end{array}$ & \multicolumn{2}{c}{$\begin{array}{c}\text { Number of events exceeding } \\
\text { rain-garden storage }\end{array}$} \\
\hline Rain garden & Above ground & Below ground & Inches/hour & Predicted & Observed \\
\hline Turf & 1.36 & 0.6 & 0.28 & 6 & 5 \\
Prairie & 1.57 & 1.34 & .88 & 1 & 0 \\
\hline
\end{tabular}


of infiltration, an even greater amount of precipitation would likely be retained and infiltrated over time if the precipitation intensity were equal to or less than the median infiltration rates listed in table 6. During April through November 2004-07, only 3 measured precipitation events in the prairie-clay rain garden and 13 in the turf-clay rain garden had 60-min precipitation intensities greater than the median infiltration rate as well as precipitation depths greater than the minimum depth required to exceed rain-garden storage capacity (assuming zero infiltration). There were no precipitation events in the sand rain gardens that satisfied the same criteria.

Additional runoff volume can also be temporarily stored by the soils below a rain garden to a depth equal to the uppermost limiting layer. The volume of these void spaces in the soil, the drainable porosity (or specific yield), may have more influence on a rain garden's ability to temporarily store runoff than the ponding depth. The specific yield is the ratio of the volume of water that drains from a saturated soil owing to the attraction of gravity to the total volume of the soil (Fetter, 2001). By use of the same calculations previously described, an estimate was made of the volume of water needed to saturate the soils below the turf- and prairie-clay rain gardens. The volume, after normalizing by rain garden and contributing rooftop area, was then compared to individual precipitation events that equaled or exceeded the soil volume and resulted in pooled water. The approximate depth of soil down to the uppermost limiting layer, based on soil-core descriptions, was 1.5 and $3 \mathrm{ft}$ for the turf- and prairie-clay rain gardens,

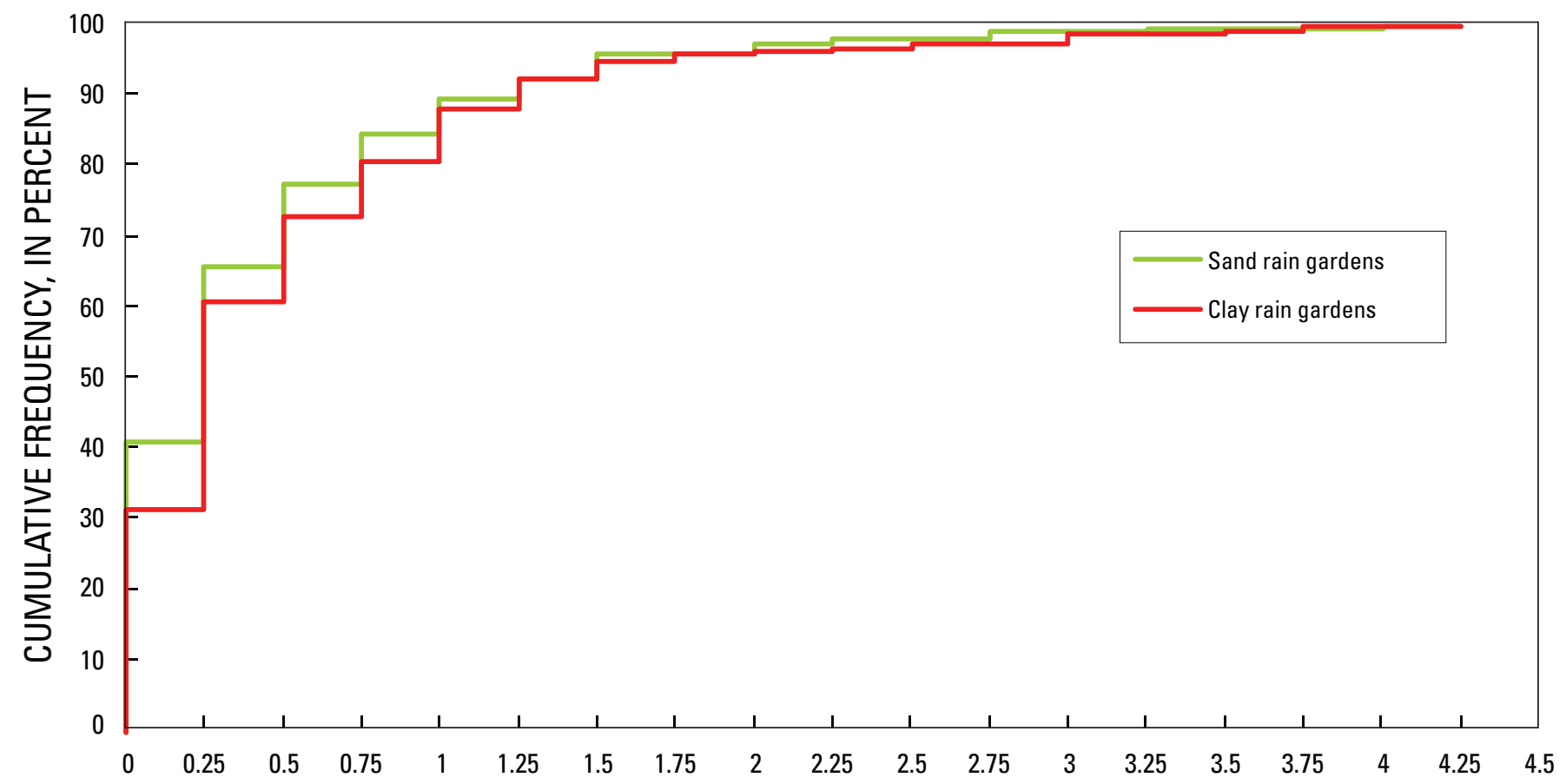

PRECIPITATION DEPTH, IN INCHES

Figure 13. Cumulative frequency of precipitation measured at the sand and clay study sites between water years $2004-08$. 
respectively (fig. 8). Soils down to these respective depths ranged from sand to sandy clay. An average soil texture of silt was selected to approximate the full range of specific yield in the gardens. Specific yield for unconsolidated silt deposits was estimated to be 18 percent based on published values (Johnson, 1967). By use of these parameters, the volume of runoff from the rooftop combined with the amount of direct precipitation required to saturate the turf- and prairie-clay rain gardens was 0.61 and 1.34 in., respectively. The number of precipitation events equal to or exceeding these thresholds was summed for April through November 2004-07. Fortysix of the 62 precipitation events equal to or exceeding 0.61 in. resulted in pooled water in the turf-clay rain garden. In the prairie-clay rain garden, 11 out of 17 precipitation events equal to or exceeding 1.34 in. resulted in pooled water. The total storage capacity of each rain garden would be a sum of storage both above and below ground. Table 6 details the quantities of each variable used to predict when the total storage capacity of the turf- and prairie-clay rain gardens would be exceeded and compares them to the observed number of events that exceeded storage capacity during April through November 2004-07. Of the six observed precipitation events exceeding the turf-clay rain garden total storage capacity, five were predicted using the values in table 6. Similarly, a single precipitation event was predicted to exceed the total storage capacity of the prairie-clay rain garden and none was observed. The criteria used to create table 6 were then applied to the prairie-clay rain garden in water year 2008, when the contributing drainage area was doubled. Four out of four predicted precipitation events exceeding the total storage capacity of the prairie-clay rain garden were observed.

Many design manuals promote the area of a rain garden as an important variable for accepting runoff, emphasizing the ratio of drainage area to receiving area. Oftentimes, those space requirements cannot be met or poor soil conditions preclude the location of a rain garden in an area where space may be available. If surficial area is unavailable, then storage of runoff can be created by excavating to a greater depth, even in the presence of clay. In the prairie-clay rain garden, for example, the time required to go from saturated to pre-event soil-moisture conditions could range from approximately 7 to $34 \mathrm{hr}$, well below the $48 \mathrm{hr}$ commonly prescribed as a design specification for standing water. This estimate assumes an infiltration rate in the limiting clay layer of 0.04 to $0.20 \mathrm{in} / \mathrm{hr}$ (Hillel, 1982). Sixty-eight percent of all precipitation events measured during April through November 2004-07 had an antecedent dry period greater than $34 \mathrm{hr}$. By applying measurements of the appropriate soil properties, environmental managers and engineers may improve the tailoring of design specifications of rain gardens for new or retrofitted areas.

\section{Effects of Antecedent Conditions and Precipitation Intensity on Storage}

The lack of appreciable effluent from the turf and prairievegetated rain gardens is a function of the above- and belowground storage capacity of the rain garden and the infiltration rate of the underlying soils. If the supply rate of water to the rain garden is greater than the infiltration rate, excess water will accumulate in the rain garden and eventually become runoff when the level of water exceeds the height of the rain garden berm. Although effluent discharge was rare, there were multiple times when influent exceeded infiltration into underlying soils and resulted in pooled water.

Results from the CART analysis of climatologic variables and the presence of pooled water indicated that 60-min precipitation intensity largely determined whether or not water would pool in both the turf- and prairie-sand rain gardens (fig. 14A). Most discharge events that produced "wet" conditions were from high-intensity precipitation events of greater than $0.24 \mathrm{in} / \mathrm{hr}$. The high saturated hydraulic conductivity of sand allows water to infiltrate quickly, oftentimes exceeding the rate at which water would discharge into the rain garden. However, as the rate of water influent to the rain garden exceeded the infiltration rate, water would be stored above ground within the rain-garden boundaries. Of the few discharge events producing "wet" conditions from low intensity events, all were a result of saturated soils from recent events.

Similar to the sand rain gardens, both precipitation intensity and the number of antecedent dry days between precipitation events were important factors that controlled when water would pool in the turf-clay and prairie-clay rain gardens (fig. 14B). As in the sand rain gardens, the results of the CART analysis were similar for both vegetation types. The low saturated hydraulic conductivity of clay would require considerably more time between precipitation events to drain than sand. Subsequently, most "wet" conditions in both the turf-clay and prairie-clay rain gardens were a result of precipitation within the last 5 days. Similarly, Ishtok and Boersma (1986) concluded that antecedent moisture is more important than the magnitude or intensity of rainfall in controlling the occurrence of runoff. Pitt and others (1999) found infiltration rates in clay were affected by a strong interaction of compaction and moisture. Antecedent moisture could act as a surrogate for antecedent dry days, because soil moisture would decrease with increasing time between precipitation events. Secondary to antecedent dry days was precipitation intensity. All "wet" conditions in the prairie-clay rain garden were a result of not only a short amount of time between precipitation events but also precipitation intensity greater than approximately $0.3 \mathrm{in} / \mathrm{hr}$. This condition was also true in the turf-clay rain garden, although the relation was not quite as strong. 


\section{SAND RAIN GARDENS}

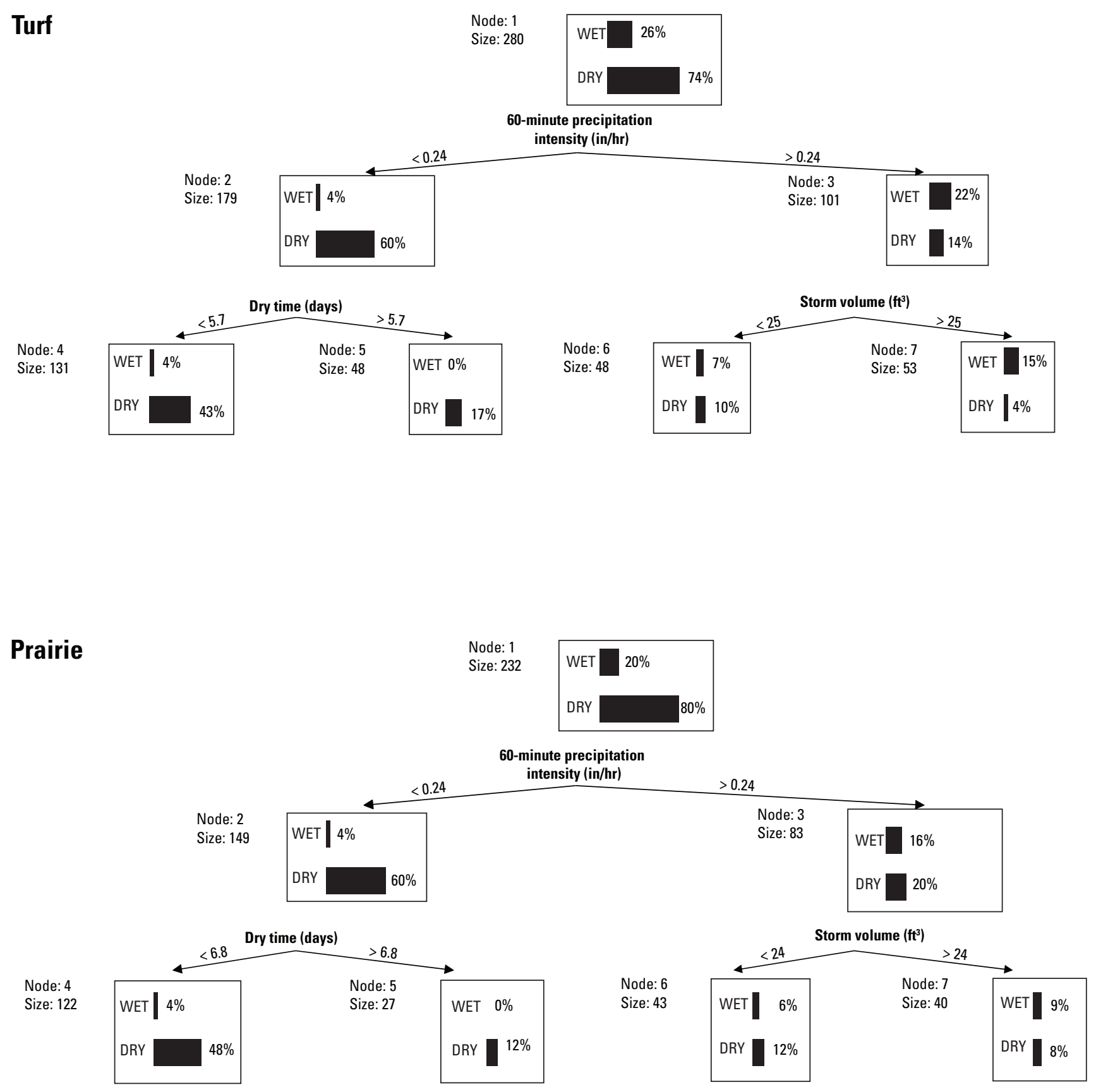

Figure 14A. Results of CART analysis illustrating relevant factors that determine if water would pool in the sand rain gardens. (\%, percent; in/hr, inches per hour; <, less than) 


\section{CLAY RAIN GARDENS}

Turf

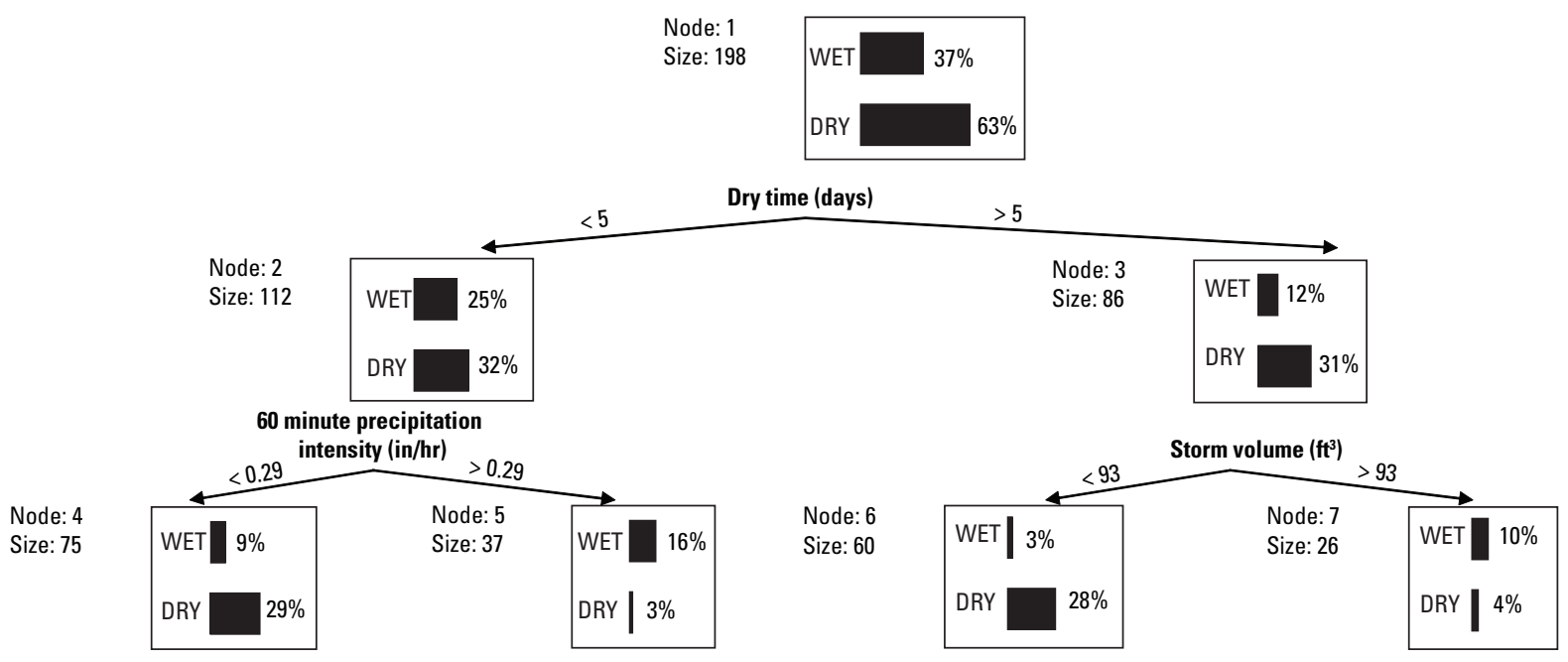

\section{Prairie}
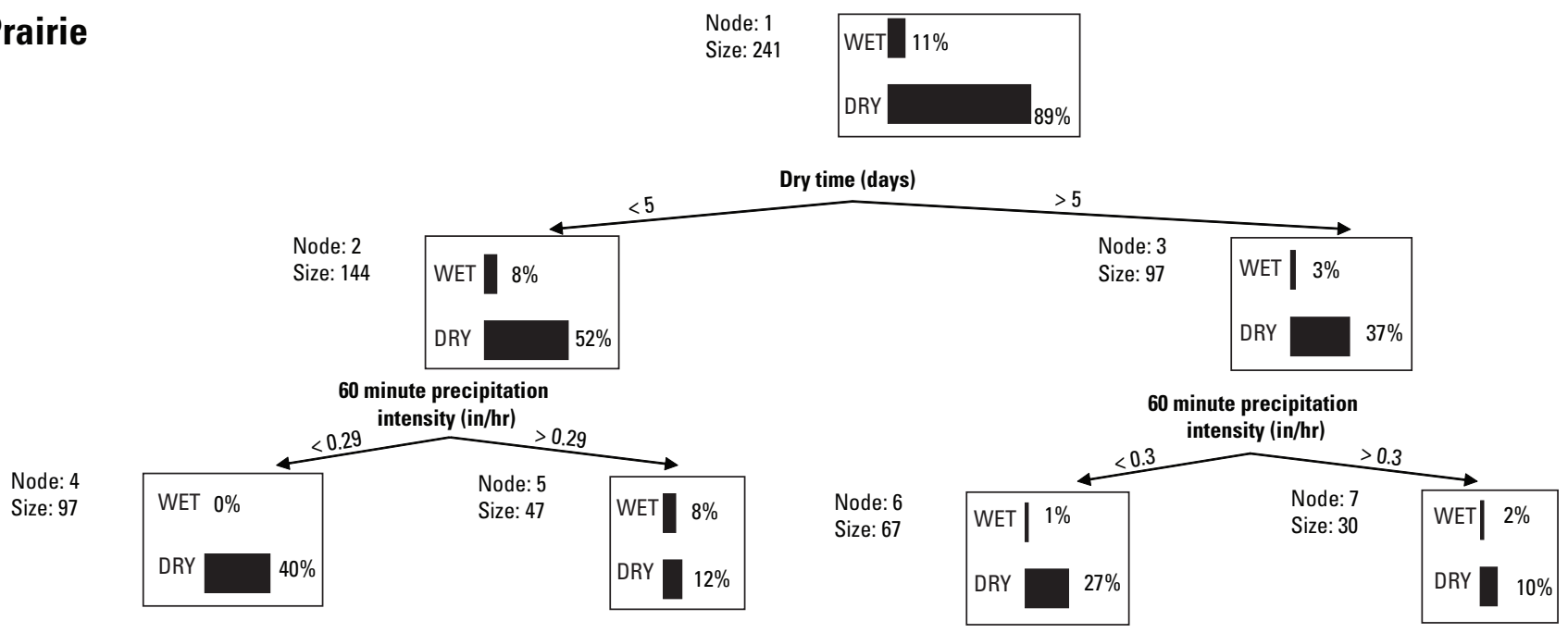

Figure 14B. Results of CART analysis illustrating relevant factors that determine if water would pool in the clay rain gardens. $(\%$, percent; in/hr, inches per hour; <, less than) 


\section{Seasonal and Temporal Changes to Infiltration Rates}

Infiltration rates were estimated at each rain garden by use of a simplified falling head technique. Estimates of infiltration rates for soil types and vegetative species were compared to discern seasonal and temporal changes. Median infiltration rates in sand rain gardens were greater than those in clay, regardless of vegetative species. Furthermore, in both sand and clay, prairie rain gardens had higher median infiltration rates than turf rain gardens. In general, infiltration rates were higher during spring and summer than fall and winter for all rain gardens.

\section{Sand Site}

Table 7 shows the number of discharge events producing pooled water during each water year as well as a statistical summary of estimated infiltration rates during the study period. Median infiltration rates in the prairie-sand rain garden are greater than in the turf-sand rain garden at 4.2 and $2.5 \mathrm{in} /$ hour, respectively. The large standard deviation in the prairie-sand rain garden suggests greater variability in infiltration rates (fig. 15). At the beginning of the study, the prairie-sand rain garden had a greater number of discharge events that resulted in pooled water than did the turf-sand rain garden (table 7). That may have been a function of the structure of the soil and immature root development of the prairie vegetation shortly after planting. The upper $4.5 \mathrm{ft}$ of soil in the prairie-sand rain garden contained greater amounts of clay and silt than the turf-sand rain garden. Destruction of the natural soil matrix as well as removal of mature vegetation during rain-garden construction in the sand study area may have influenced infiltration rates during the first study year. In later years, as the prairie root system matured, perturbation of the soils may have allowed more rapid infiltration and, thus, fewer "wet" conditions. Improvements to soil structure and infiltration rates in the prairie-sand rain garden may have been more prevalent than in the turf-sand rain garden because of the abundance of sand directly beneath the turf-sand rain garden. Evidence of improved infiltration rates in the prairiesand rain garden is illustrated in figure 15. Median values for estimated infiltration rates in the prairie-sand rain garden steadily increased from 2004 through 2006. A slight decrease in 2007 may be a result of when the discharge events occurred. Five discharge events resulted in pooled water in the prairiesand rain garden in 2007, and three of them were in August. By comparison, in 2006, three of the four discharge events that produced "wet" conditions were in May. Spring in this case is defined as March through May and summer is defined as June through August. Although results of the Mann-Whitney test indicated no difference in infiltration rate in the prairiesand rain garden between spring and summer (at the 5-percent significance level), many of the estimated infiltration rates in the prairie-sand rain garden were greater in spring than in summer, especially during 2006 and 2007 (fig. 16). Diamond and Shanley (1998) found a similar seasonal pattern when assessing the spatial and temporal variability of infiltration capacity of major soil types in Ireland. This pattern was not reproduced in the turf-sand rain garden, which showed a similar range of infiltration rates in the summer and spring. Unlike the prairie-sand rain garden, infiltration rates in the turf-sand rain garden remained relatively consistent, ranging from 2 to $4 \mathrm{in} / \mathrm{hr}$, except in 2005 when a single infiltration rate of nearly $10 \mathrm{in} / \mathrm{hr}$ was estimated. It is unclear why this single infiltration rate is much larger than all the others, but it was included when changes to infiltration rates over time and season in the turf-sand rain garden were compared.

Winter and fall were excluded from statistical tests due to a limited sample population. Water pooled in the prairiesand rain garden only twice during winter, in February 2004 and January 2005, resulting in an estimated infiltration rate of 0.75 and $2.28 \mathrm{in} / \mathrm{hr}$, respectively. There were no pooled water events during winter in the turf-sand rain garden. Muthanna and others (2006) found the hydraulic performance of an experimental rain garden in Norway was not impacted by the climatic factors experienced during the cold season. Given the paucity of pooled water conditions in the sand rain gardens during winter months, it is likely their hydraulic function was not appreciably altered by frozen soils.

Table 7. Statistical summary of infiltration rates in the turf-grass and prairie rain gardens in sand and clay.

[Precipitation events resulting in pooled water were used to estimate an infiltration rate by use of the falling head technique. --, not measured; SD, standard deviation; $\mathrm{COV}$, coefficient of variation; in $/ \mathrm{hr}$, inches per hour]

\begin{tabular}{|c|c|c|c|c|c|}
\hline \multirow[b]{3}{*}{ Rain Garden } & \multicolumn{5}{|c|}{ Number of events with pooled water } \\
\hline & \multicolumn{5}{|c|}{ Water year } \\
\hline & 2004 & 2005 & 2006 & 2007 & 2008 \\
\hline Turf-sand & 16 & 7 & 14 & 18 & 25 \\
\hline Prairie-sand & 24 & 4 & 7 & 14 & -- \\
\hline Turf-clay & 25 & 11 & 20 & 18 & -- \\
\hline Prairie-clay & 5 & 3 & 3 & 7 & 10 \\
\hline
\end{tabular}

\begin{tabular}{clrl}
\hline \multicolumn{4}{c}{ Estimated infiltration rate (in/hr) } \\
\hline \multicolumn{4}{c}{ All water years } \\
\hline Mean & Median & SD & COV \\
3.00 & 2.50 & 1.60 & 0.50 \\
6.50 & 4.20 & 4.70 & 0.70 \\
& & & \\
0.31 & 0.28 & 0.19 & 0.60 \\
1.00 & 0.88 & 0.55 & 0.54 \\
\hline
\end{tabular}



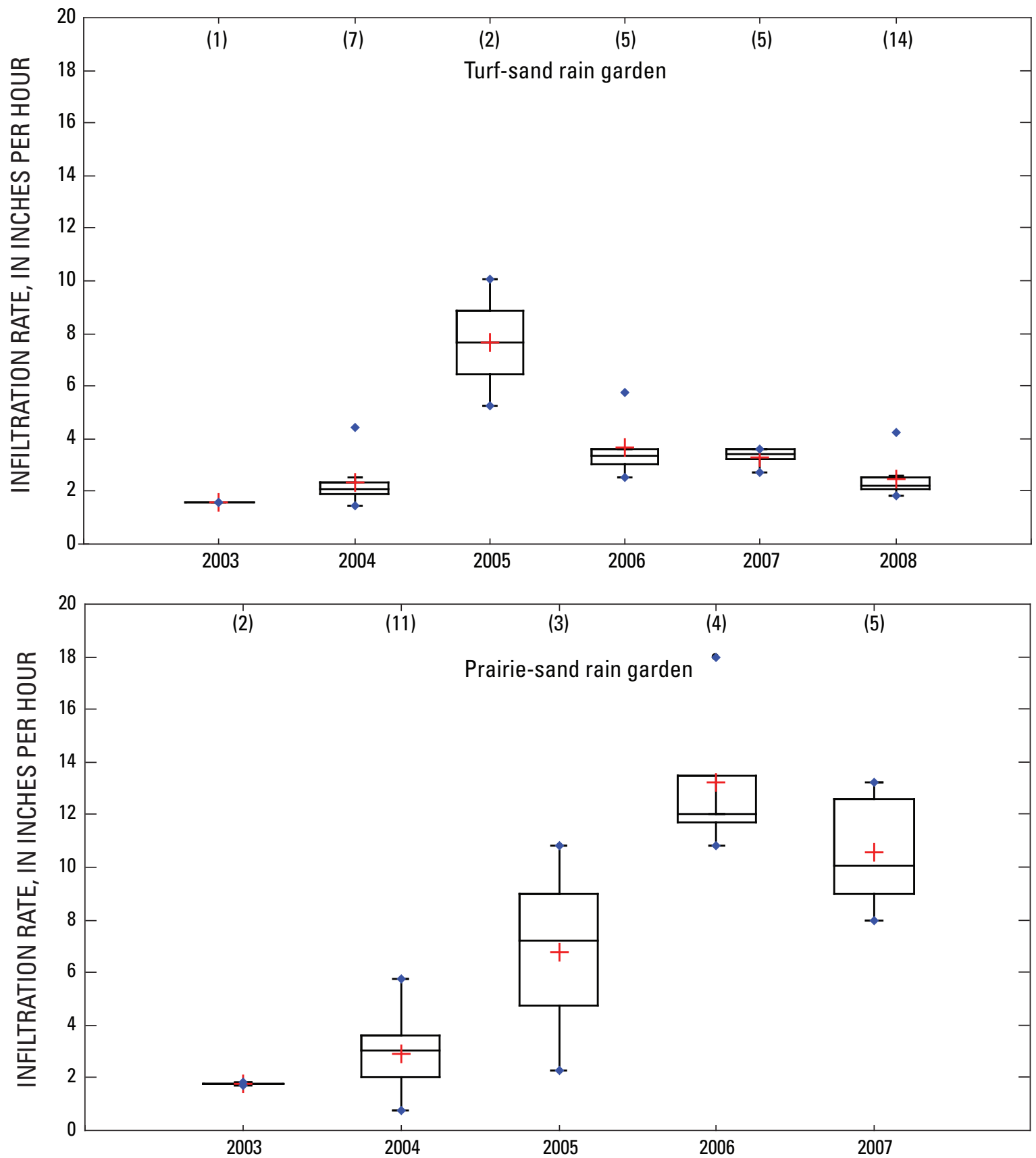

WATER YEAR

Figure 15. Comparison of infiltration rates by water year in the sand rain gardens. Infiltration rates are based on falling-head technique during events with pooled water.

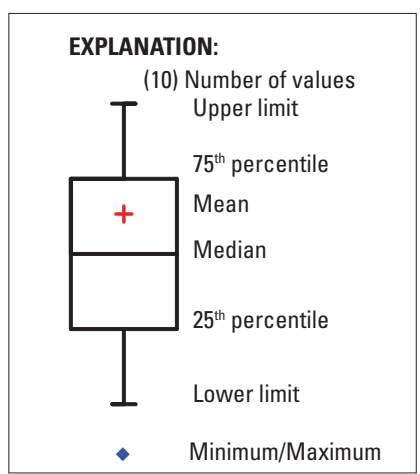



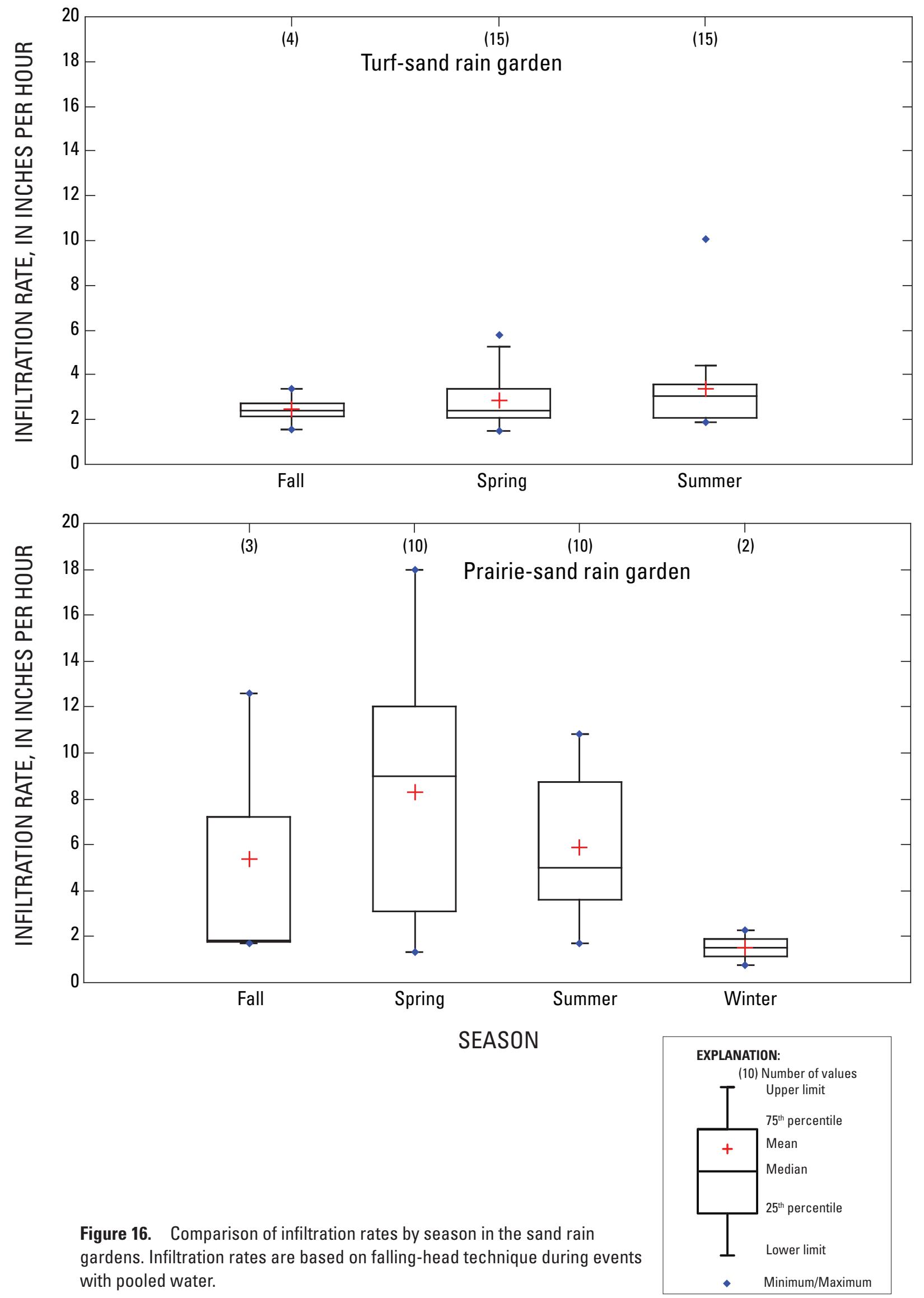


\section{Clay Site}

Table 7 shows the number of discharge events producing pooled water during each water year as well as a statistical summary of estimated infiltration rates during the study period in the clay rain gardens. Median infiltration rates in the prairie-clay rain garden are more than three times greater than in the turf-clay rain garden at 0.88 and $0.28 \mathrm{in} / \mathrm{hr}$, respectively. Despite the disparity between overall median infiltration rates, the turf-clay rain garden exhibited a general increase in annual median infiltration rates from 2004 through 2007, ranging from less than $0.2 \mathrm{in} / \mathrm{hr}$ in 2004 and 2005 to more than $0.4 \mathrm{in} / \mathrm{hr}$ in 2006 and 2007 (fig. 17). Although the increase in infiltration rates appears modest, it represents an appreciable improvement over those measured prior to rain-garden construction. Infiltration rates of approximately $0.1 \mathrm{in} / \mathrm{hr}$ were measured by use of a double-ring infiltrometer at the clay rain-garden site prior to rain-garden construction. Destruction of the natural soil matrix by excavation and compaction can decrease hydraulic conductivity (Pitt and others, 1999; Legg and others, 1996). Because the soil structure prior to this study was likely degraded from construction activities, it would not be unusual to see an increase in infiltration rates regardless of vegetation type. Hino and Shutto (1987) found the growth of grass altered the structure of soils within 2 months of establishment, and they measured increases in saturated hydraulic conductivity from $0.24 \mathrm{in} / \mathrm{hr}$ in bare soil to nearly $4.0 \mathrm{in} / \mathrm{hr}$ for grass-covered soil. Despite annual differences in median infiltration rates, seasonal differences were not as apparent. Comparison of seasonal infiltration rates by use of a combination of the Kruskal-Wallis test for multiple groups and Dunn's test suggested that infiltration rates in the turf garden were greatest during summer months, at the 5-percent significance level. Winter infiltration rates in the turf-clay rain garden were the lowest of all seasons and had a median value of $0.11 \mathrm{in} / \mathrm{hr}$, which is the same as the infiltration rate measured prior to rain-garden construction. Furthermore, infiltration rates increased by season, with winter rates the lowest, then spring, fall, and finally, summer the highest (fig. 18).

Similar to the turf-clay rain garden, an increase in annual median infiltration rates was also measured in the prairie-clay rain garden (fig. 17). Rates ranged from $0.6 \mathrm{in} / \mathrm{hr}$ to more than $1.0 \mathrm{in} / \mathrm{hr}$ in 2004 and 2008, respectively. As with turf grass, prairie vegetation can improve hydraulic conductivity by creating or improving macropores or both from extensive root growth (Beven and Germann, 1982). Under favorable circumstances, macropore systems can be developed in as little as 1 to 2 years (Beven and Germann, 1982). Little can be inferred about the direction of median infiltration rates in 2005 and 2006 because of the lack of data. Because a lack of pooled water would preclude estimation of an infiltration rate, as was often the case in the prairie-clay rain garden, the rate at which water infiltrated into the soil was likely greater than the rate water flowed into the rain garden. Therefore, fewer rather than more data points in figure 17 would qualitatively suggest improved infiltration rates given similar precipitation characteristics to other study years. Results of the MannWhitney test indicate no difference between spring and summer infiltration rates at the 5-percent significance level for the prairie-clay rain garden. Because the prairie-clay rain garden lacked "wet" conditions during the fall and winter, an evaluation of seasonal differences was limited to only spring and summer. 

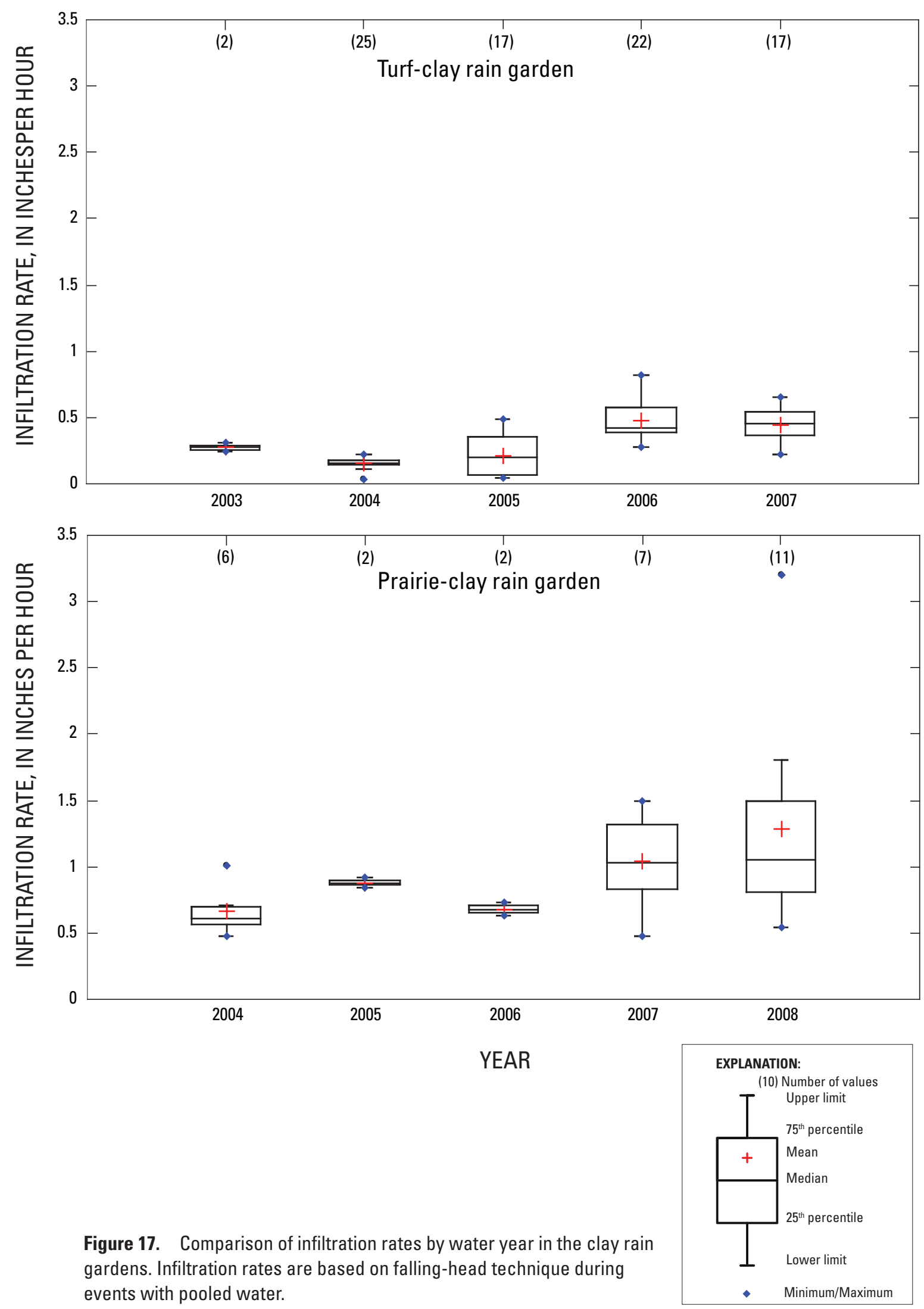

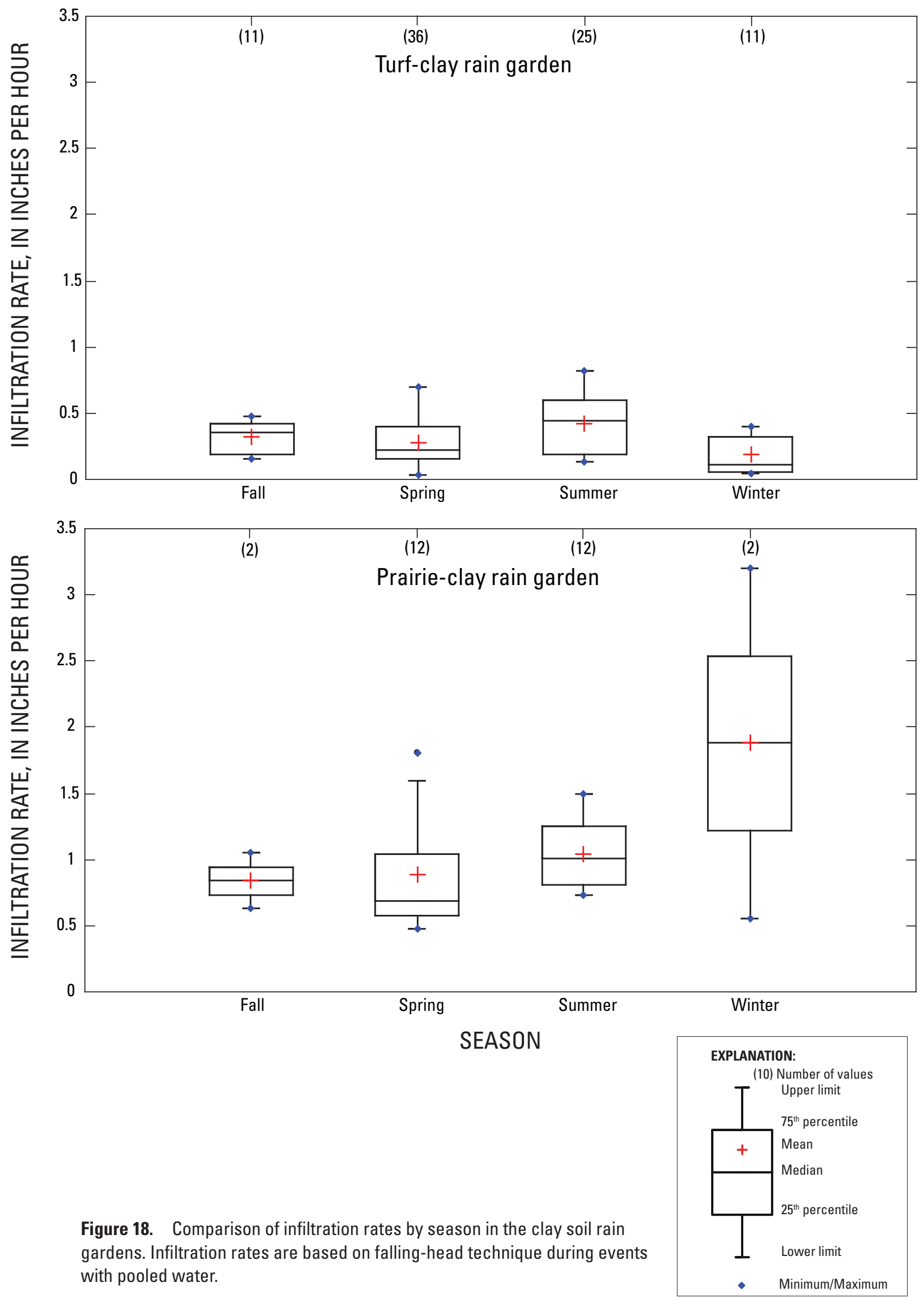


\section{Vegetative Effects on Soil Moisture}

Analysis of the temporal variation of soil moisture can be qualitatively useful in estimating the timing, depth, and duration of recharge events (Delin and Herkelrath, 1999). Interpretation of fluctuations in soil moisture in the unsaturated zone is based on the premise that water in the soil above the vegetative-rooting depth travels upward in response to evapotranspiration. Water below that depth drains downward to the water table as recharge. This evapotranspiration/drainage boundary is further described by Delin and others (2000) who used soil moisture as a means to compute a volumetric mass balance of the unsaturated zone.

Time-lapse imagery in conjunction with the vertical soilmoisture profile illustrates the combined effect of root systems and evapotranspiration on soil moisture in the prairie-clay rain garden during an extended dry period in 2005 (fig. 19A). In figure 19A, a diurnal fluctuation in soil moisture with increasing depth becomes more evident from May through August 2005. Multiple days with no precipitation force the prairie root system to tap into deeper sources of soil moisture. The development of root systems into deeper soil depths may increase the infiltrative capacity of a rain garden by creating macropores and other fissures that allow for rapid water movement. This might also explain, in part, the larger median infiltration rate measured in the prairie-clay rain garden compared with that in the turf-clay rain garden (table 7). The diurnal fluctuation in soil moisture over the same time period is not as prominent in the turf-clay rain garden (fig. 19B). This is likely due to the shallow root depth of turf grass. Only the uppermost soil layer ( 0.5 feet below land surface) showed appreciable decline in soil moisture.

In September 2008, an effort was made to track the temporal changes in soil moisture after artificially flooding the prairie-clay rain garden. Because there was evidence of a limiting clay layer approximately $3 \mathrm{ft}$ below the land surface (fig. 8), water was expected to pool and accumulate at or near this depth. However, if the prairie root system was capable of penetrating through the limiting layer, then water could slowly percolate downward. Soil moisture was measured vertically by use of a neutron logger at four intervals: before flooding, $1 \mathrm{hr}$ after flooding, and 3 and 6 days after flooding. As expected, soil moisture rapidly increased in the uppermost soil layers shortly after flooding of the rain garden began (fig. 20). After $1 \mathrm{hr}$, modest increases in moisture levels continued down to a depth of approximately $8 \mathrm{ft}$, which is $5 \mathrm{ft}$ below the demarcation of the upper limiting layer. Soil moisture returned to pre-flooding levels from the uppermost layer to a depth of approximately $6 \mathrm{ft}$ after 3 days; however, moisture from 6 to $8 \mathrm{ft}$ remained high even after 6 days. It is likely a second, thinner layer at approximately 8 to $9 \mathrm{ft}$ was limiting the downward movement of water and causing a perching effect, and, thus, elevated moisture levels above $8 \mathrm{ft}$ for an extended period of time. Despite the lower limiting layer, water still advanced downward as recharge, as is evident by the increase in soil moisture after 3 and 6 days post rain garden flooding to depths below $10 \mathrm{ft}$. An increase in soil moisture in the upper limiting layer, although small, might indicate perturbation of the soil by prairie roots. The clay rain gardens were excavated shortly after the flood test to verify the extent of soil structure and root morphology. The results are discussed later in this report.

Additional evidence of deep penetrating prairie root systems is further illustrated in the prairie-sand rain garden (fig. 21). In 2005, there was little change in soil-moisture levels after extended periods of no precipitation in the turfsand rain garden at 1.6 feet below land surface and the prairiesand rain garden at 2.6 feet below land surface. In 2007, however, soil moisture in the prairie-sand rain garden began to display a diurnal fluctuation during extended dry periods, which is an indication of the effect of evapotranspiration. In contrast, the turf-sand moisture levels showed a steady decline in soil-moisture levels, and this is more likely a function of evaporation and drainage than the water needs of a root system. 


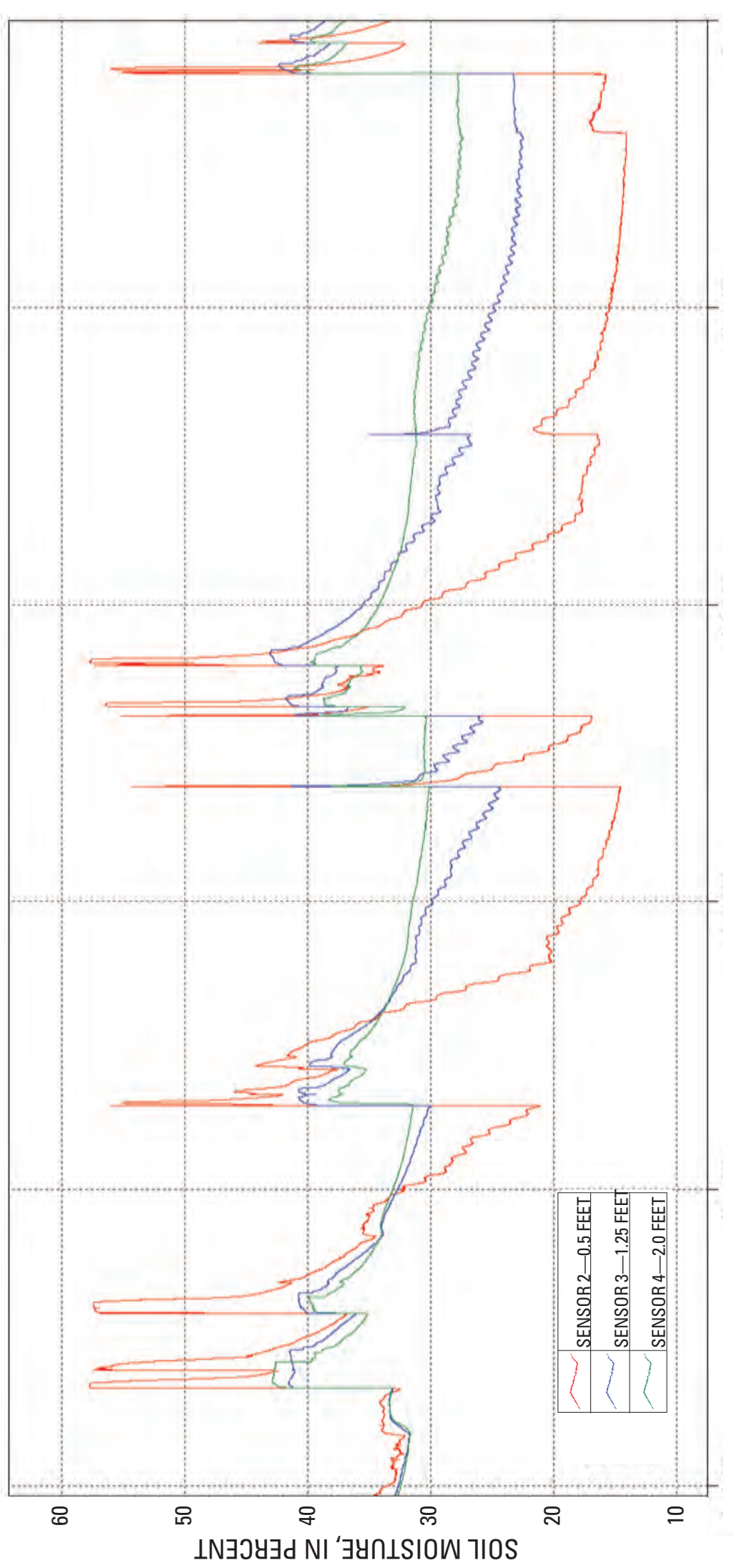

옳

올

总

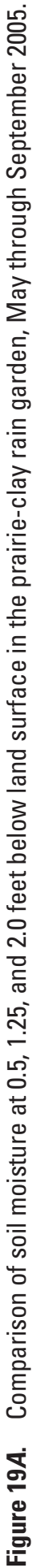




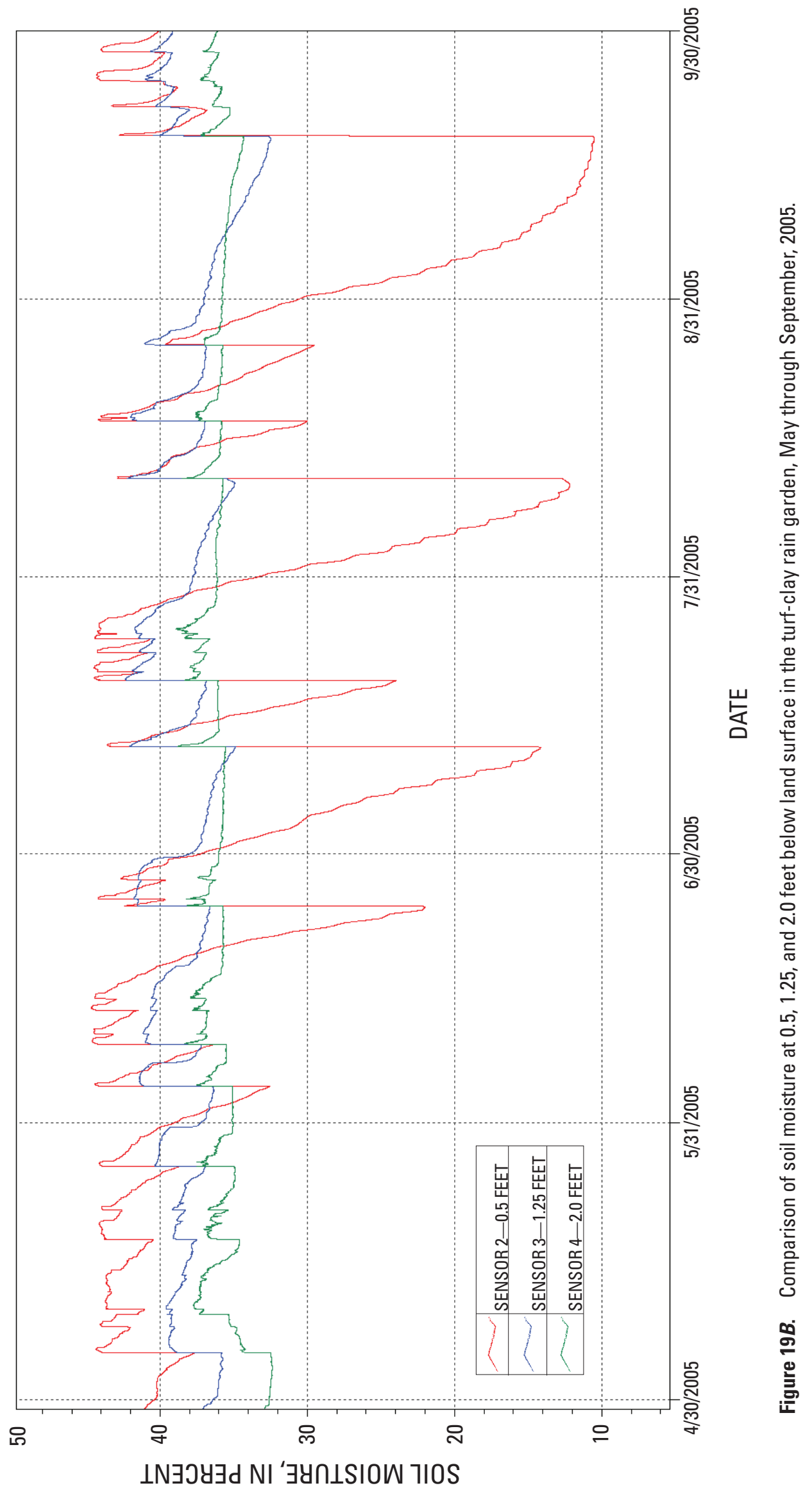




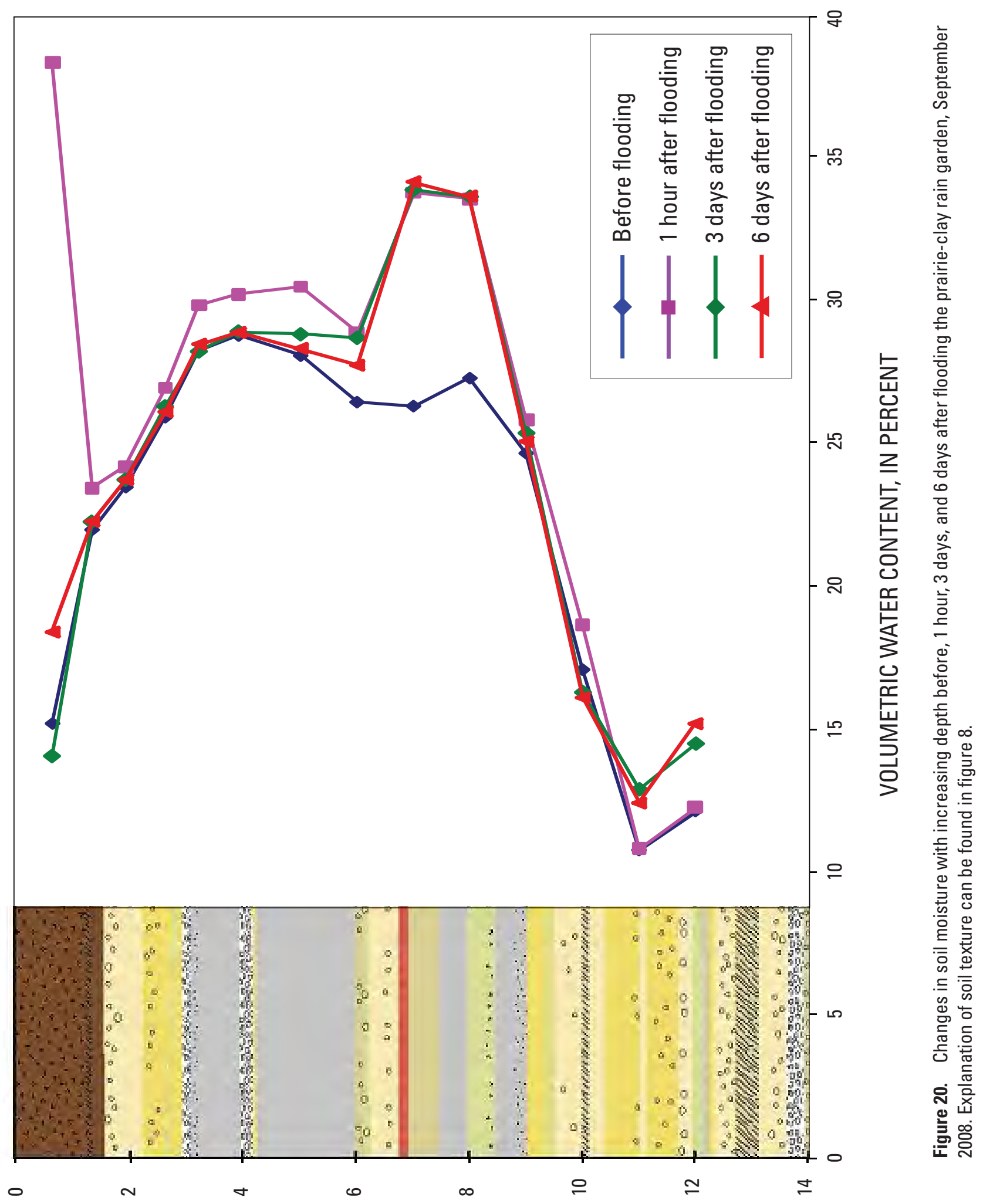

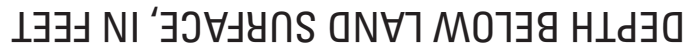



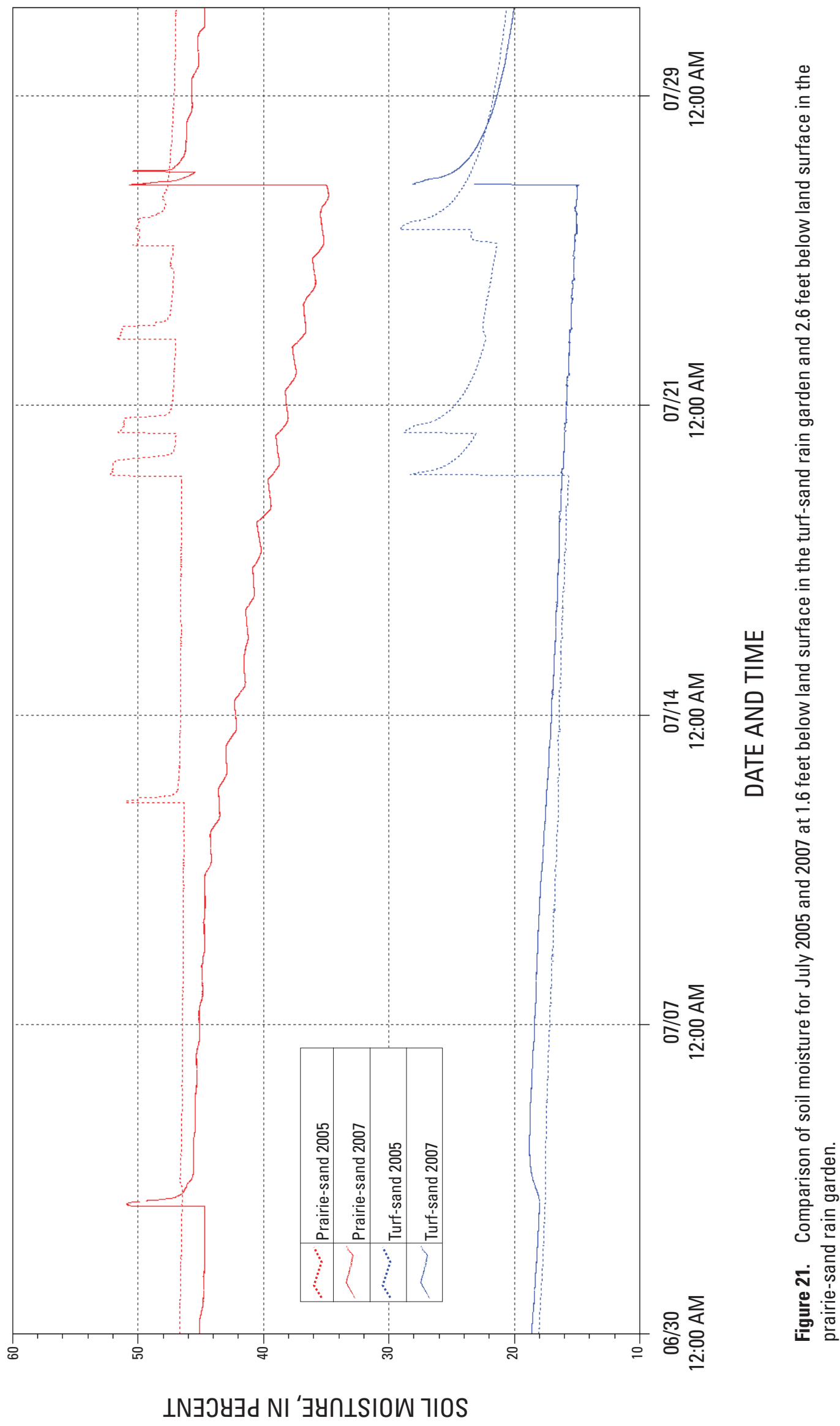


\section{Comparison of Soil Properties and Root Morphology}

In October 2008, 5 years after planting the rain gardens, an observation trench was excavated through the approximate center of the prairie- and turf-clay rain gardens to characterize differences in soil properties and rooting between vegetation types. Although the turf- and prairie-clay rain gardens had similar soil textures and soil-horizon designations, there were striking differences in soil characteristics between the two clay gardens. Table 8 details physical characteristics of the soil profiles in the turf- and prairie-clay rain gardens.

The differences in soil properties were associated with water and air movement within the two rain gardens. The soil under the prairie-vegetated rain garden, although possessing the remnants of a limiting clay layer, appeared well-drained. At no time during field sampling did water enter the prairie-clay trench from the profile wall or its bottom. Conversely, there was clear evidence of a perched water table at approximately $0.7-1.0 \mathrm{ft}$ below the surface of the turfplanted rain garden. Water not only seeped into the turf-clay trench during sampling, but a strongly gleyed horizon was present from $1.05-2.95 \mathrm{ft}$ and was indicative of an anaerobic, saturated environment; a weakly gleyed horizon in the prairieclay garden ( $0.66 \mathrm{ft}$ in thickness) ended at $1.51 \mathrm{ft}$ below the surface. Oxidized mottles and other redox features within the master B horizon of the turf-clay rain garden further indicated a fluctuating perched water table. Moreover, the $\mathrm{Bt}$ horizon above the gleyed layer in the turf-clay soil possessed a large enough clay fraction that it was classified as a silt loam relative to the $\mathrm{Bt}$ horizon in the prairie-clay soil. This observation may indicate a transfer of the finer clay fraction to lower horizons in the prairie-clay profile. Finally, a substantial clay fraction was found in the lower B horizons of both rain gardens as shown by an angular, blocky to somewhat platey structure as well as the laboratory particle-size classification of silty clay loams.

The 2008 soil-profile descriptions also indicated differences in flora and fauna activity between the prairie- and turf-clay rain gardens (table 8). Many fine roots extended from the surface down to $0.46 \mathrm{ft}$ in the turf-clay rain garden (absolute rooting depth in the turf-clay garden was $0.56 \mathrm{ft}$ ), but roots extended to a depth of $4.7 \mathrm{ft}$ in the prairie-clay rain garden. Moreover, many roots were found within the Btg horizon of the prairie-clay garden but they were absent from the Btg horizon of the turf-clay rain garden. The greater amount and depth of rooting in the prairie-clay rain garden coincided with greater macrofauna activity, indicated by many earthworms, along with many abandoned worm channels and cavities once occupied by roots. These channels were either lined with organic matter or were redox features indicating the movement of water and air into lower horizons of the prairieclay rain garden. Conversely, there was little evidence of macrofauna activity in the soil under the turf. This biological activity was also evident in the horizon boundaries of the prairie-clay soil which were wavy, irregular, and clear. In contrast, the horizon boundaries of the turf-clay soil were largely smooth and abrupt. Collectively, these differences in soil properties point to greater pedoturbation in the prairie-clay rain garden than in the turf-clay rain garden.

Although the absolute values of dry root mass were low relative to mature turf and prairie systems, differences were evident between the prairie-clay and turf-clay gardens (table 8 ). The root number and dry mass in each rain garden mirrored the differences of organic matter throughout each profile, in that the prairie-clay garden had more dry root mass than the turf-clay rain garden. Although both soils had an Oi and an A horizon, the organic accumulation of the prairie-clay rain garden was 0.4 in thicker in the Oi horizon and 4 percent greater in the A horizon relative to the turf-clay soil. This percent difference in organic matter between gardens carried into the $\mathrm{B}$ horizons, where the prairie soil averaged 1 percent greater organic matter than the turf-clay garden. These bioticderived differences appear to also correlate with differences in soil bulk density between the two rain gardens. Both rain gardens displayed the typical increase in bulk density with depth; however, the soil of the prairie-clay rain garden was less dense overall than the turf-clay soil, particularly in the A and Btg horizons..

Similar to the differences in dry root mass, rooting behavior also varied between the prairie- and turf-clay rain gardens. Roots were present in all horizons sampled within the prairie-clay soil, where the absolute rooting depth extended to $4.7 \mathrm{ft}$; in contrast, roots were found only in the $\mathrm{A}$ and $\mathrm{Bt}$ horizons within the turf-clay rain garden. The absence of roots below $1.05 \mathrm{ft}$ in the turf-clay soil may be explained by the interaction between the shallow-rooting turf grass and the saturated, anaerobic character of the thick Btg horizon. Conversely, the prairie-vegetation species appeared to penetrate the "limiting layer" and allowed mixing of surface organics, macrofauna, water, and air deeper into the profile.

There were marked differences in rooting morphology (for example, in length, density, and amount) between the prairie- and turf-clay rain gardens (table 9). The mean dry root mass per volume of soil within the A horizon of the prairie-clay rain garden was almost double that of the turfclay rain garden; root mass within the Bt was similar between rain gardens. The SRL was 23 percent lower and 14 percent greater in the A and Bt horizons, respectively, of the prairieclay soil than in the same horizons in the turf-clay soil. Conversely, the RLD was 75 percent greater in the A horizon of the prairie-clay rain garden relative to the turf-clay soil, and the RLD in the Bt horizon was similar in both rain gardens. These differences in rooting morphology concurred with the differences in SOM and bulk density between the two rain gardens, where greater root mass equated with higher SOM and lower bulk density. Moreover, these quantitative measures capture the interaction between vegetation types and soil that controls rain-garden function. 

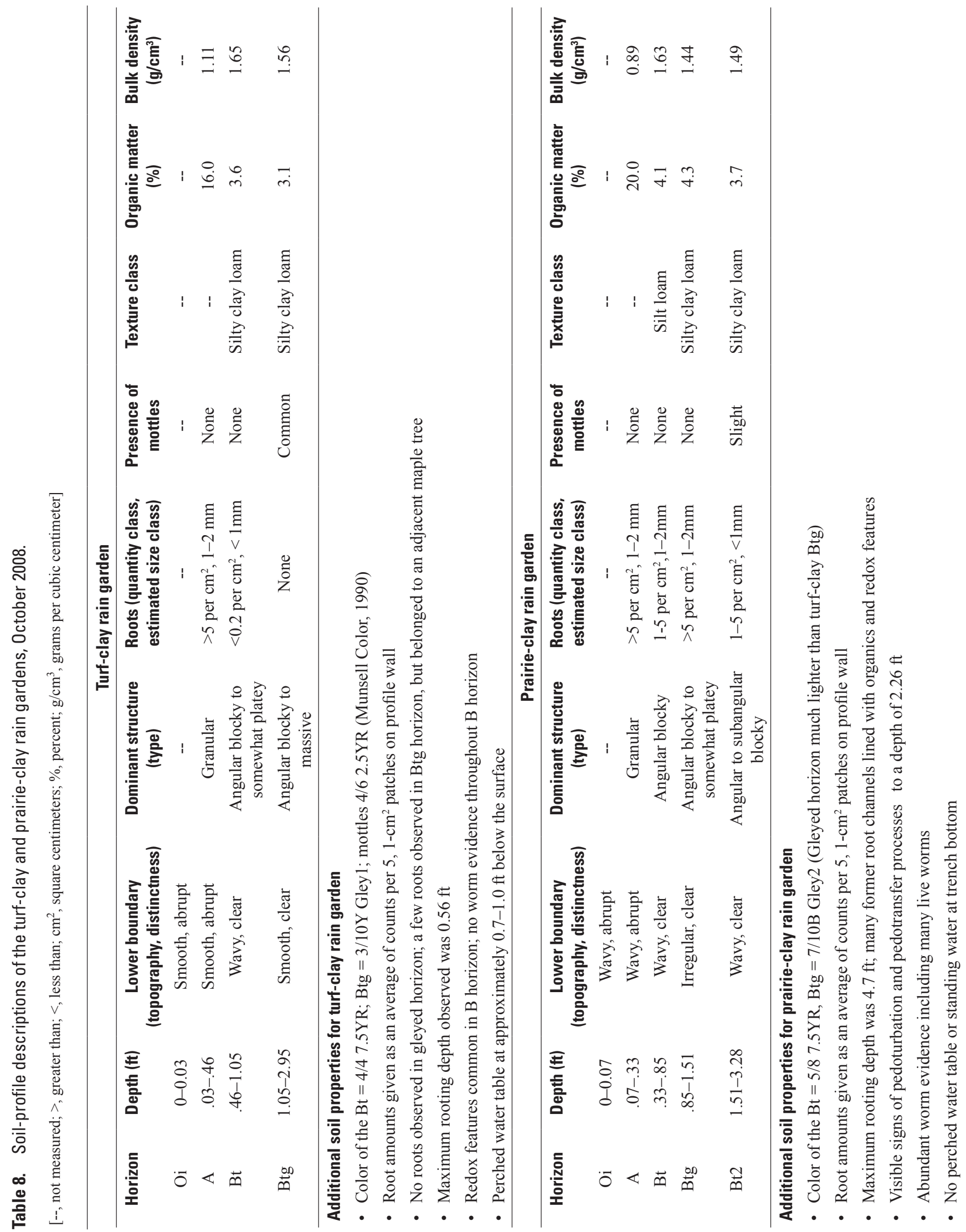
Table 9. Rooting dynamics below the turf-clay and prairie-clay rain gardens, October 2008.

[SRL, specific root length; RLD, root length density. $\mathrm{mg} / \mathrm{cm}^{3}$, milligrams of root per volume of dry soil; $\mathrm{m} / \mathrm{g}$, meters of root length per weight of dry root; $\mathrm{cm} / \mathrm{cm}^{3}$, centimeters of root length per volume of dry soil; --, not measured]

\begin{tabular}{|c|c|c|c|c|}
\hline \multicolumn{5}{|c|}{ Turf-clay rain garden } \\
\hline Horizon & Depth (ft) & $\begin{array}{l}\text { Mean root } \\
\text { dry mass } \\
\left(\mathrm{mg} / \mathrm{cm}^{3}\right)\end{array}$ & $\begin{array}{c}\text { Total SRL } \\
(\mathrm{m} / \mathrm{g})\end{array}$ & $\begin{array}{c}\text { RLD } \\
\left(\mathrm{cm} / \mathrm{cm}^{3}\right)\end{array}$ \\
\hline $\mathrm{Oi}$ & $0-0.03$ & -- & -- & -- \\
\hline A & $0.03-0.46$ & 0.10 & 38.0 & 0.48 \\
\hline $\mathrm{Bt}$ & $0.46-1.05$ & .03 & 61.3 & .19 \\
\hline Btg & $1.05-2.95$ & -- & -- & -- \\
\hline \multicolumn{5}{|c|}{ Prairie-clay rain garden } \\
\hline Horizon & Depth (ft) & $\begin{array}{l}\text { Mean root } \\
\text { dry mass } \\
\left(\mathrm{mg} / \mathrm{cm}^{3}\right)\end{array}$ & $\begin{array}{c}\text { Total SRL } \\
(\mathrm{m} / \mathrm{g})\end{array}$ & $\begin{array}{c}\text { RLD } \\
\left(\mathrm{cm} / \mathrm{cm}^{3}\right)\end{array}$ \\
\hline Oi & $0-0.07$ & -- & -- & -- \\
\hline A & $0.07-0.33$ & 0.18 & 46.9 & 0.84 \\
\hline $\mathrm{Bt}$ & $0.33-0.85$ & .04 & 70.3 & .20 \\
\hline Btg & $0.85-1.51$ & .02 & 68.9 & .19 \\
\hline Bt2 & $1.51-3.28$ & .01 & 30.2 & .07 \\
\hline
\end{tabular}

The length of a plant's root system largely controls its acquisition of water and nutrients, as well as the development of soil structure. Although species vary widely in their specific root length, the relative differences observed between the two rain gardens studied here helps explain the differences observed in soil development (Fitter, 1985). Species with a relatively small investment in root biomass per unit root length, high SRL, may possess an advantage for exploiting pulses of water in the soil by quickly increasing root length (Eissenstat and Caldwell, 1989; Chapin, 1989). Moreover, a lower energy cost per unit length of root may facilitate soil development, as the plant can afford to explore a greater volume of soil and typically turn over roots at higher rates (Grime and others, 1986). In a study of orange trees grown in disturbed soil, rootstocks with higher SRL and greater RLD were able to extract water more rapidly than those with lower SRL (Eissenstat, 1991).

This interaction between roots and soil may explain the greater soil development in the prairie-clay rain garden than in the turf-clay rain garden. Within the A horizon, the prairie roots not only had a greater mass of roots per volume of soil, but also a lower mass investment per length of root such that there was almost double the rooting length per volume of soil in the prairie-clay rain garden relative to the turf-clay rain garden. This trend between rain gardens carried into the $\mathrm{Bt}$ horizon, although the differences were much less pronounced than in the A horizon. Therefore, the ability of the prairie vegetation to build an energetically less-expensive root system may have facilitated higher rates of root proliferation, leading to greater soil development and improved infiltration for water and air, than in the turf-clay rain garden. The 2008 profile observations in table 8 support this hypothesis.

Finally, the absolute values of root mass, SRL, and RLD for these rain gardens were low relative to published values for grasses. The relative immaturity of these systems and the one-time sampling late in the growing season may help explain this difference. Moreover, the differences in soil development reported here are based on two rain gardens. Sequential coring and additional treatment replication would increase the reproducibility of these data.

\section{Conclusions}

Recent trends in urban runoff mitigation have resulted in technologies that focus on infiltration. One such technology, known as a rain garden, is a shallow depression that accepts runoff generated from nearby impervious surfaces and infiltrates that runoff back into the underlying soil. In addition, rain gardens may provide some level of water-quality benefit by settling, filtration, adsorption, decomposition, ion exchange, and volatilization. Rain gardens range in size but are commonly used as a way to retrofit existing urban areas where land requirements often preclude larger structures. Although the use of rain gardens is increasing, there appears to be no clear consensus on how soils at the site might limit the use of an infiltration device. The use of rain gardens and other infiltration devices could be expanded if additional information about soil amendments and sizing criteria was available to mitigate the uncertainty of requiring infiltration in soils that have low infiltration rates.

To that end, the U.S Geological Survey, in cooperation with a consortium of 19 cities, towns, and villages in Dane County, Wis., evaluated the effectiveness of rain gardens with different soil types and vegetative species for stormwater infiltration. Two rain gardens, one planted with turf grass and the other with native prairie species, were constructed sideby-side in two locations of different soil types, sand and clay. Instruments were installed to measure the volumetric mass balance of each rain garden from late 2003 through 2008. Root morphology, soil texture, and other subsurface properties were characterized so that differences in storage capacity and infiltration rates between vegetation and soil type could be understood.

Results of the study show that each rain garden, regardless of vegetation or soil type, was capable of storing and infiltrating most of the runoff during the 5-year study period. Median infiltration rates for rain gardens in sand were greater than those in clay. Within each soil type, rain gardens with prairie vegetation had greater median infiltration rates than those with turf grass. Infiltration was generally highest during spring and summer and lowest during winter. Despite reduced infiltration rates during months when soils were likely frozen, the hydraulic function of the rain gardens did not appear to be appreciably altered. 
The success of the rain gardens was primarily because the 5 to 1 ratio of contributing area to receiving area (4 to 1 for the prairie-clay rain garden) and $0.5 \mathrm{ft}$ depth were capable of storing and infiltrating nearly all the stormwater. Even when the contributing area was doubled to 10 to 1 in the turf-sand rain garden and 8 to 1 in the prairie-clay rain garden, only a limited amount of outflow from the rain garden was generated. Approximately 90 percent of all precipitation measured over the 4-year study was capable of being stored in the gardens (assuming an infiltration rate of zero). The percentage of precipitation events fully retained by each rain garden increased to nearly 100 percent when the median infiltration rate and specific yield of subsurface soils were included in the estimates. Precipitation intensity and antecedent dry days were the dominant secondary controlling factors in determining when the storage capacity of a rain garden might be exceeded and result in pooled water above ground.

Because of the large area of rooftop contributing runoff to each rain garden, evapotranspiration was a small percentage of the overall water balance. Therefore, most of the annual runoff volume influent to each rain garden, regardless of vegetation or soil type, was recharged back into groundwater. However, differences in annual recharge between the turf grass and prairie rain gardens in clay were slightly greater than the differences between rain gardens planted with the same vegetative species in sand. This is largely because a much smaller amount of evapotranspiration was estimated for prairie species than for turf grass.

Examination of soil development and root morphology in the rain gardens 5 years after planting clearly showed greater biological activity of flora and fauna in the prairie-clay rain garden than in the turf-clay rain garden. Roots in the prairieclay garden were found to a depth of $4.7 \mathrm{ft}$ compared with $0.46 \mathrm{ft}$ in the turf-clay rain garden. The greater amount and depth of rooting in the prairie-clay rain garden coincided with greater earthworm activity along abandoned worm channels and cavities once occupied with roots. These channels were either lined with organic matter or redox features, indicating the movement of water and air into lower horizons within the prairie-clay rain garden. Moreover, the prairie roots had a lower mass investment per length of root such that there was almost double the rooting length per volume of soil in the prairie-clay soil relative to the turf-clay soil. Collectively, these differences point to greater pedoturbation and soil development in the prairie-clay rain garden relative to the turfclay rain garden, and this may result in greater capacity of the prairie-clay rain garden to store and infiltrate stormwater than the turf-clay rain garden.

By applying measurements of the appropriate soil properties to rain-garden design, environmental managers and engineers may improve the tailoring of design specifications of rain gardens for new or retrofitted areas. If surficial area is unavailable to temporarily store runoff above ground, then storage can be created by excavating to a greater depth, even in the presence of clay.

\section{Acknowledgments}

The authors would like to thank Eric Booth, Justin Haasch, and Kristian Corby of the U.S. Geological Survey for their tireless efforts installing, calibrating, and maintaining the diversity of equipment used in this study; Roger Bannerman of the Wisconsin Department of Natural Resources for insight on the big-picture perspective behind rain gardens; and Greg Fries of the city of Madison for providing personnel and equipment when needed. Without their cooperation and effort, this study would not have been possible.

\section{References}

Allen, R.G., Pereira, L.S., Raes, D., and Smith, M., 1998, Crop evapotranspiration - Guidelines for computing crop water requirement: Food and Agriculture Organization of the United Nations, Irrigation and Drainage paper 56, $300 \mathrm{p}$.

Asseng, S., Richter, C., and Wessolek, G., 1997, Modeling root growth of wheat as the linkage between crop and soil: Plant Soil, v. 190, p. 267-277.

Bannerman, R.T., Owens, D.B., Dodds, R.B., and Hornewer, N.J., 1993, Sources of pollutants in Wisconsin stormwater: Water Science Technology, v. 28, no. 3-5, p. 241-259.

Beven, K., and Germann, P., 1982, Macropores and water flow in soils: Water Resources Research, v. 18, no. 5, p. 1311 1325.

Blake, G. R., and Hartge, K. H., 2002, Bulk density, in Klute, E.A., ed., Methods of soil analysis, pt. 1 of Physical and mineralogical methods: Madison, Wis., Soil Science Society of America, Inc., p. 363-375.

Brander, K.E., Owen, K.E., and Potter, K.W., 2004, Modeled impacts of development type on runoff volume and infiltration performance: Journal of the American Water Resources Association, v. 40, no. 4, p. 961-969.

Breiman, L., Friedman, J., Stone, C., and Olshen, R.A., 1984, Classification and regression trees ( $1^{\text {st }} \mathrm{ed}$.): Chapman and Hall, 368 p.

City of Lenexa, 2003, Rain garden design principles: City of Lenexa Watershed Management Division, Lenexa, Kans. Accessed July 28, 2009, at http://www.raintorecreation.org/ DesignPrinciples.html.

Costello, L.R., Clark, J.R., Jones, K.S., and Matheny, N.P., 2000, A guide to estimating irrigation water needs of landscape plantings in California: the landscape coefficient method and WUCOLS III: University of California Cooperative Extension, $150 \mathrm{p}$. 
Craig, N., 2007, Exploring biotic and social aspects of rain gardens in Dane County, Wisconsin: Madison, Wis., University of Wisconsin, Masters of Science thesis, $254 \mathrm{p}$. Accessed July 28, 2009, at http://balserlab.wikispaces.com/ Nicole + Craig + Thesis.

Davis, A. 2005, Green engineering principles promote low-impact development: Environmental Science and Technology, A-pages, v. 39, no. 16, p. 338A-344A.

Delin, G.N., Healy, R.W., Landon, M.K., and Bohlke, J.K., 2000, Effects of topography and soil properties on recharge at two sites in an agricultural field: Journal of the American Water Resources Association, v. 36, no. 6, p. 1401-1416.

Delin, G.N., and Herkelrath, W.N.,1999, Long-term monitoring of unsaturated-zone properties to estimate recharge of the Bemidji crude-oil spill site, in Morganwalp, D.W., and Buxton, H.T., eds., U.S. Geological Survey Toxic Substances Hydrology Program: Proceedings of the technical meeting, Charleston, South Carolina, March 8-12, 1999: U.S. Geological Survey Water-Resources Investigations Report 99-4018C, p. 143-151.

Diamond, J., and Shanley, T., 1998, Infiltration rate assessment of some major soils: Wexford, Ireland, Teagasc_-The Agriculture and Food Development Authority, Johnstown Castle Research Centre, 14 p.

Dietz, M.E. and Clausen, J.C., 2005, A field evaluation of rain garden flow and pollutant treatment: Water, Air, and Soil Pollution, v. 167, p. 123-138.

Dietz, M.E. and Clausen, J.C., 2006, Saturation to improve pollutant retention in a rain garden: Environmental Science and Technology, v. 40, no. 4, p. 1335-1340.

Dunn, O.J., 1964, Multiple comparisons using rank sums: Technometrics, v. 6, p. 241-252.

Eissenstat, D.M. 1991, On the relationship between specific root length and the rate of root proliferation: a field study using citrus rootstocks: New Phytologist, v. 118, p. 63-68.

Eissenstat, D.M., and Caldwell, M.M., 1989, Invasive root growth into disturbed soil of two tussock grasses that differ in competitive effectiveness: Functional Ecology, v. 3, p. $345-353$.

Eissenstat, D.M., Huang, X.M., and Lakso, A.N., 2006, Modeling carbon allocation below ground: Acta Horticulturae, v. 707, p. 143-150.

Fetter, C.W., 2001, Applied hydrogeology (4 ${ }^{\text {th }}$ ed.): Upper Saddle River, N.J., Prentice Hall, 598 p.

Fitter, A.H., 1985, Functional significance of root morphology and root system architecture, in Fitter, A.H., ed., Ecological interactions in soil: plant, microbes, and animals: London, Blackwell Scientific Publications, p. 87-106.
Gee, G.W., and Or, D., 2002, Particle-size analysis, in Dane, J.H., and Clarke, T., eds., Methods of soil analysis, pt. 4. of Physical and mineralogical methods: Madison, Wis., Soil Science Society of America, Inc., p. 255-293.

Graczyk, D.J., and Greb, S.R., 2006, Soil data at sites near Geneva Lake, Lake Geneva, Wisconsin, and Long Lake, near New Auburn, Wisconsin: U.S. Geological Survey Open-File Report 2006-1191, 19 p.

Grime, J.P., Crick, J.C., and Rincon, J.E., 1986, The ecological significance of plasticity, in Jennings, D.H., and Trewars, A.J., eds., Plasticity in plants: New York, Symposium of the Society of Experimental Biology, Cambridge University Press, p. 5-29.

Heiri, O., Lotter, A.F., and Lemcke, G., 2001, Loss on ignition as a method for estimating organic and carbonate content in sediments: reproducibility and comparability of results: Journal of Paleolimnology, v. 25, p.101-110.

Helsel, D.R., and Hirsch, R.M., 1992, Statistical methods in water resources: New York, Elsevier, 522 p.

Hillel, D., 1982, Introduction to soil physics: London, Academic Press Limited, 364 p.

Hino, M., and Shutto, H., 1987, A laboratory experiment on the role of grass for infiltration and runoff processes: Journal of Hydrology, v. 90, p. 303-325.

House, L.B., Waschbusch, R.J., and Hughes, P.E., 1993, Water quality of an urban wet detention pond in Madison Wisconsin, 1987-88: U.S. Geological Survey Open-File Report 93-172, 57 p.

Ishtok, J.D., and Boersma, L., 1986, Effect of antecedent rainfall on runoff during low-intensity rainfall: Journal of Hydrology, v. 88, p. 329-342.

Johnson, A.I., 1967, Specific yield-compilation of specific yields for various materials: U.S. Geological Survey Water Supply Paper 1662-D, 74 p.

Kussow, W., 1995, Soil disturbance effects on nutrient losses from Kentucky bluegrass turf: University of Wisconsin, Wisconsin Turfgrass Research Reports, v. XIII, p. 129-133.

Legg, A.D., Bannerman, R.T., and Panuska, J., 1996, Variation in the relation of rainfall to runoff from residential lawns in Madison, Wisconsin, July and August 1995: U.S. Geological Survey Water-Resources Investigations Report 96-4194, 11 p.

Marlin, M.A., Ensign, S.H., and Wheeler, T.L., 2002, Pollutant removal efficacy of three wet detention ponds: Journal of Environmental Quality, v. 31, no. 2, p. 654-660. 
Mickelson, D., 2007, Landscapes of Dane County, Wisconsin: Wisconsin Geological and Natural History Survey Educational Series 43, $36 \mathrm{p}$.

Monteith, J.L., and Unsworth, M.H., 1990, Principals of environmental physics (2nd ed.): London, Edward Arnold, $289 \mathrm{p}$.

Munsell Color, 1990, Munsell soil color charts: Newburgh, N.Y., Munsell Color, Macbeth, Division of Kollmorgen Instruments Corp.

Muthanna, T.M., Thorolfsson, S.T., and Viklander, M., 2006, Winter hydrology in a cold climate rain garden, in American Society of Agricultural and Biological Engineers, Annual International Meeting, Portland, Ore., July 9-12, 2006.

National Oceanic and Atmospheric Administration, Environmental Data and Information Service, National Climatic Center, 2003 - 2007, Local climatological data, Madison, Wisconsin-Annual summary with comparative data: accessed September 23, 2008, at http://www.ncdc. noaa.gov.

National Oceanic and Atmospheric Administration, National Weather Service, 1972, Observing handbook no.2: Substation Observations, Data: Silver Spring, Md., Acquisition Division, Office of Meteorological Operations, $77 \mathrm{p}$.

Natural Resources Conservation Service, 2009, National Cooperative Soil Survey, Web Soil Survey 2.2: accessed July 29, 2009, at http://websoilsurvey.nrcs.usda.gov/app/

Pettersson, T., 1998, Water quality improvement in a small stormwater detention pond: Water Science and Technology, v. 38 , no. 10 , p. $115-122$.

Pitt, R., Clark, S., Johnson, P., and Voorhees, J., 2008, Evapotranspiration and related calculations for stormwater biofiltration devices: Proposed calculation scenario and data, in Stormwater and urban water systems modeling: Guelph, Ontario, Computational Hydraulics International, monograph 16, p. 309-340.

Pitt, R., Lantrip, J., Harrison, R., Henry, C.L., and Xue, D., 1999, Infiltration through disturbed urban soils and compost-amended soil effects on runoff quality and quantity: U.S. Environmental Protection Agency, EPA/600/R-00/016, $233 \mathrm{p}$.

Prince George's County, 1993, Design manual for use of bioretention in stormwater management: Landover, M., Prince George's County Department of Environmental Protection, Watershed Protection Branch [variously paginated].
Rawls, W.J., Gimenez, D., and Grossman, R., 1998, Use of soil texture, bulk density and slope of water retention curve to predict saturated hydraulic conductivity: Transactions of the American Society of Agricultural Engineers, v. 41, no. 2, pp. 983-988.

Schoeneberger, P.J., Wysocki, D.A., Benham, E.C., and Broderson, W.D., (eds.), 2002, Field book for describing and sampling soils, ver. 2.0: Lincoln, Neb., Natural Resources Conservation Service, Soil Survey Center, 22 p.

Sentek Party, Ltd., 1999, Diviner 2000 access tube installation guide, ver. 1.0, $88 \mathrm{p}$.

Simmons, D., and Reynolds, R., 1982, Effects of urbanization on baseflow of selected south-shore streams, Long Island, New York: Journal of the American Water Resources Association, v. 18, no. 5, p. 797-805.

Smith, R.A., and Hunt, W.F., 2007, Pollutant removal in bioretention cells with grass cover, in Proceedings of the World Environmental and Water Resources Congress 2007: Restoring our natural habitat, $11 \mathrm{p}$.

Steinke, K., Stier, J.C., Kussow, W.R., and Thompson, A., 2007, Prairie and turf buffer strips for controlling runoff from paved surfaces: Journal of Environmental Quality, v. 36 , no. 2 , p. $426-439$.

Steuer, J.J., and Hunt, R.J., 2001, Use of a watershedmodeling approach to assess hydrologic effects of urbanization, North Fork Pheasant Branch basin near Middleton, Wisconsin: U.S. Geological Survey WaterResources Investigations Report 01-4113, 49 p.

U.S. Environmental Protection Agency, 1983, Results of the Nationwide Urban Runoff Program, vol. 1-final report: Washington D.C., Water Planning Division: National Technical Information Service PB84-185552 [variously paginated].

Winer, R., 2000, National pollutant removal performance database for stormwater treatment practices ( $2^{\text {nd }}$ ed.): Center for Watershed Protection, $224 \mathrm{p}$.

Wisconsin Administrative Code, 2002, chap. NR 151.002, p. 399-410-9: accessed July 30, 2009, at http://www.legis. state.wi.us/rsb/code/nr/nr151.pdf

Wisconsin Department of Natural Resources, 2003, Rain gardens: A how-to manual for home owners: WDNR Publication PUB-WT-776 2003, 32 p. 
This page left intentionally blank 
Appendix 1 


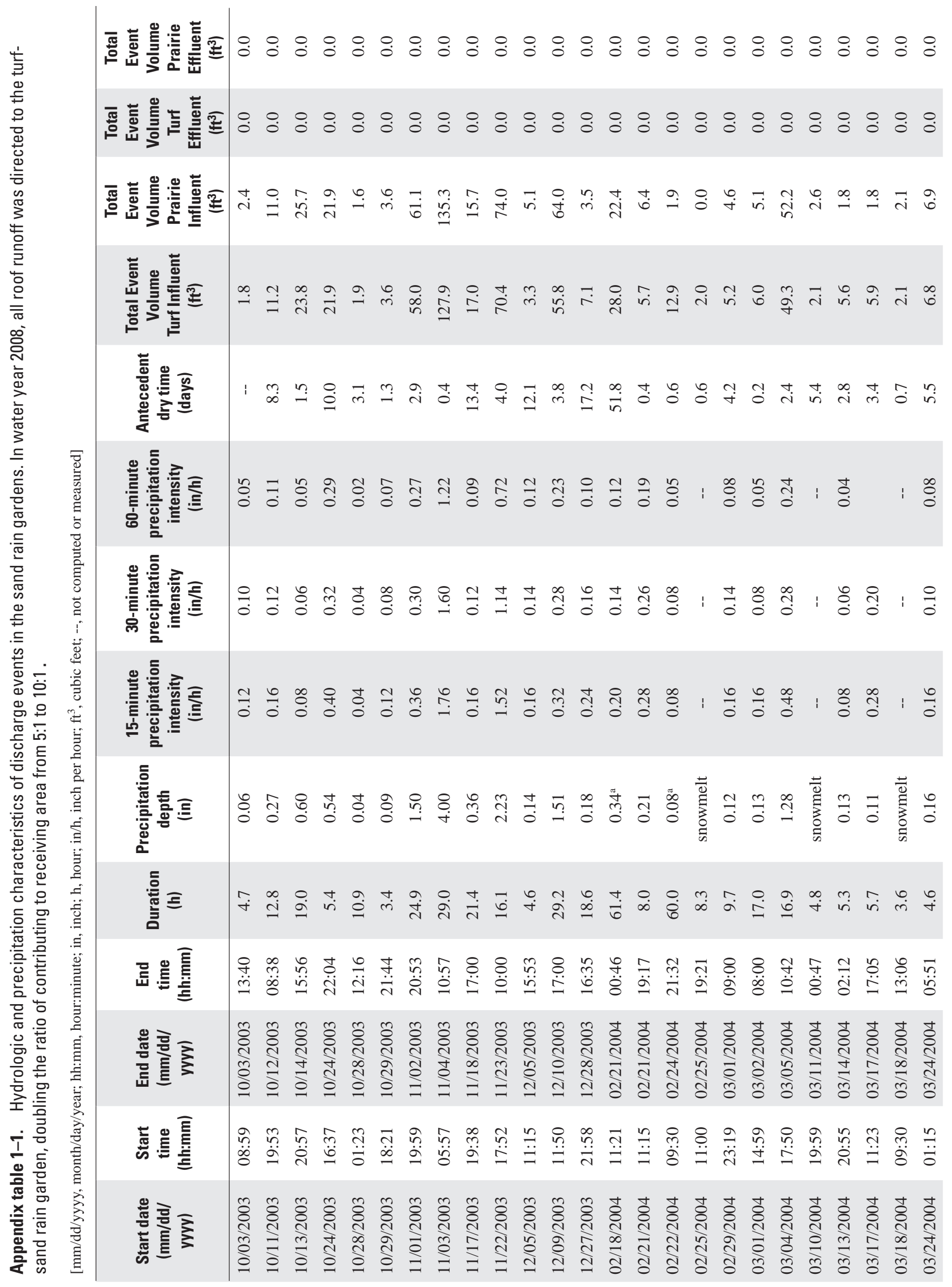




\begin{tabular}{|c|c|c|c|c|c|c|c|c|c|c|c|c|c|c|c|c|c|c|c|c|c|c|c|c|}
\hline & 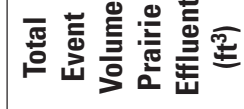 & $\because \stackrel{0}{0}$ & $\stackrel{0}{0}$ & $\stackrel{\circ}{0}:$ & $\stackrel{0}{\circ}$ & $\stackrel{0}{0}$ & $\stackrel{\circ}{\circ}$ & $\stackrel{0}{\circ}$ & 0 & $\stackrel{0}{0}$ & $\stackrel{0}{\circ}$ & $\stackrel{0}{\circ}$ & $\stackrel{0}{0}$ & & $\stackrel{0}{0}$ & $\ddot{0}$ & $\ddot{0}$ & $\ddot{0}$ & $\stackrel{0}{0}$ & $\ddot{\circ}$ & & $\stackrel{0}{0}$ & & $\stackrel{0}{\circ}$ \\
\hline 8 & 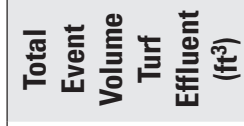 & $\stackrel{0}{0}:$ & $\stackrel{0}{0}$ & $\stackrel{0}{0}:$ & $\stackrel{0}{0}$ & $\stackrel{\circ}{\circ}$ & $\stackrel{\circ}{\circ}$ & $\stackrel{0}{\circ}$ & $\stackrel{0}{0}$ & $\stackrel{0}{0}$ & $\stackrel{0}{0}$ & $\stackrel{0}{0}$ & $\stackrel{0}{0}$ & $\stackrel{0}{0}$ & $\stackrel{0}{0}$ & $\stackrel{0}{\circ}$ & $\stackrel{0}{0}$ & $\ddot{0}$ & $\stackrel{0}{0}$ & $\stackrel{0}{0}$ & $\stackrel{0}{0}$ & $\stackrel{0}{0}$ & $\because$ & $\stackrel{\circ}{0}$ \\
\hline 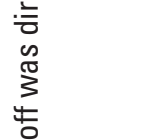 & 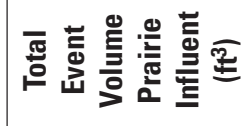 & $\frac{n}{m} \stackrel{\text { I }}{n}$ & $\stackrel{n}{n}$ & $\stackrel{9}{9} \stackrel{0}{9}$ & $\stackrel{0}{\circ}$ & $\dot{n}$ & $\begin{array}{l}0 \\
\dot{i}\end{array}$ & $\ddot{0}$ & $\stackrel{\infty}{i}$ & $\stackrel{\infty}{\stackrel{0}{\rightarrow}}$ & $\begin{array}{l}n \\
\infty \\
\infty\end{array}$ & $\stackrel{n}{=}$ & $\underset{\tilde{\sigma}}{\tilde{\sigma}}$ & $\overrightarrow{\mathrm{a}}$ & m. & $\begin{array}{l}n \\
\infty \\
\infty \\
\infty\end{array}$ & $\stackrel{m}{r}$ & n? & $\stackrel{0}{\circ}$ & $\underset{\bullet}{+}$ & İ & $\stackrel{n}{\stackrel{n}{m}}$ & $\stackrel{\odot}{+}$ & $\vec{\sigma}$ \\
\hline & 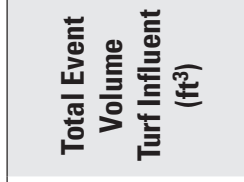 & 盀 & $\stackrel{n}{n}$ & $\stackrel{?}{-}$ & $\vec{\infty}$ & 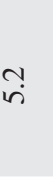 & ते & $\stackrel{n}{m}$ & $\ddot{n}$ & $\stackrel{2}{=}$ & $\ddot{n}$ & 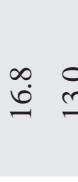 & $\stackrel{0}{c}$ & $\overrightarrow{\dot{v}}$ & $\begin{array}{l}\tilde{N} \\
\text { ה }\end{array}$ & $\underset{\infty}{\infty}$ & $\stackrel{y}{y}$ & $\stackrel{\sim}{+}$ & $\ddot{n}$ & $\stackrel{\circ}{\dot{I}}$ & 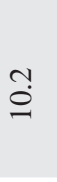 & $\vec{i}$ & $\dot{m}$ & $\stackrel{m}{\underline{I}}$ is \\
\hline 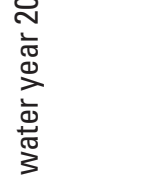 & 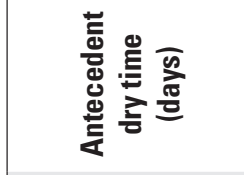 & $\stackrel{+}{\rightarrow} \stackrel{\stackrel{i}{i}}{ }$ & 9 & $\stackrel{1}{2}$ & $\hat{o}$ & $\tilde{0}$ & $\stackrel{n}{i}$ & $\ddot{n}$ & 亩 & ?ై & ? & $\underset{c}{0} \stackrel{9}{c}$ & m & فे & $\stackrel{\infty}{i}$ & กั & $\stackrel{t}{0}$ & I & $\stackrel{\circ}{+}$ & $\ddot{0}$ & $?$ & $\stackrel{\check{\infty}}{\infty}$ & $\stackrel{m}{=}$ & $\stackrel{\infty}{+} \stackrel{f}{f}$ \\
\hline 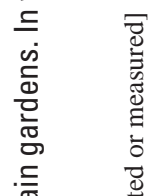 & 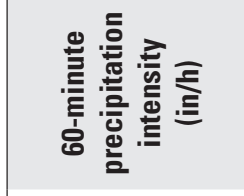 & $\begin{array}{ll}\infty & 0 \\
0 & 0 \\
0 & 0\end{array}$ & i & సֶ & כָ & i & $\frac{n}{0}$ & o̊ & : & $\stackrel{m}{0}$ & तે & $\begin{array}{ll}\overline{1} & 8 \\
0 & 8\end{array}$ & $\begin{array}{l}8 \\
0 \\
0\end{array}$ & $\stackrel{n}{\mathfrak{c}}$ & $\begin{array}{l}? \\
0\end{array}$ & $\begin{array}{l}\infty \\
\dot{0} \\
0\end{array}$ & $\stackrel{0}{0}$ & $\frac{1}{0}$ & $\frac{7}{0}$ & $\stackrel{\text { I }}{0}$ & $\frac{1}{0}$ & $\stackrel{n}{n}$ & $\frac{n}{0}$ & กै \\
\hline 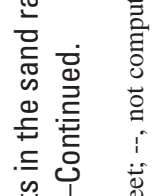 & 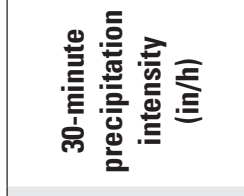 & $\stackrel{\infty}{\stackrel{\infty}{0}}$ & i & $1 \stackrel{+}{0}$ & 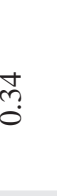 & 1 & $\stackrel{\infty}{0}$ & $\stackrel{\infty}{0}$ & 1 & $\begin{array}{l}8 \\
:\end{array}$ & $\stackrel{8}{+}$ & กै? & $\frac{1}{0}$ & ঙે & 足 & กี & $\stackrel{t}{0}$ & ปุ & $\stackrel{\infty}{0}$ & 菅 & $\stackrel{ \pm}{0}$ & $\stackrel{\text { fิ }}{0}$ & $\stackrel{\infty}{0}$ & 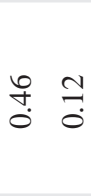 \\
\hline 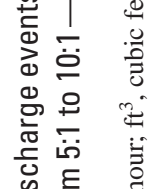 & 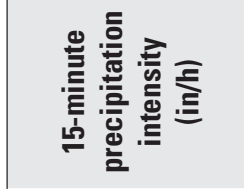 & 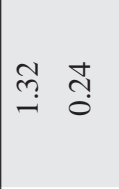 & i & : $\stackrel{\infty}{0}$ & ثُ & ?̊n & $\tilde{3}$ & $\begin{array}{l}0 \\
0 \\
0\end{array}$ & 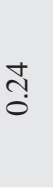 & $\stackrel{\infty}{\stackrel{\infty}{-}}$ & $\stackrel{0}{\mathbb{2}}$ & $\stackrel{0}{n}$ & $\frac{1}{0}$ & 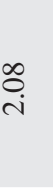 & . & $\underset{i}{\stackrel{i}{i}}$ & $\stackrel{2}{\circ}$ & ?.? & $\stackrel{ \pm}{0}$ & $\begin{array}{l}\infty \\
\infty \\
0\end{array}$ & તิ & ñ & है & $\stackrel{\circ}{\stackrel{0}{0}}$ \\
\hline 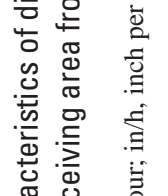 & 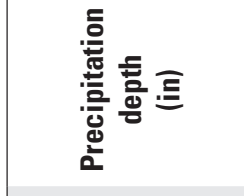 & 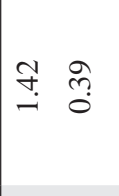 & $\begin{array}{l}\frac{1}{0} \\
\text { है } \\
0 \\
0 \\
\vdots\end{array}$ & 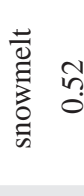 & ? & $\frac{n}{0}$ & i̊n & ñ. & : & $\tilde{n}$ & $\stackrel{t}{+}$ & $\stackrel{\text { I. }}{\text { I. }}$ & ले & $\begin{array}{l}\bar{\infty} \\
0\end{array}$ & $\stackrel{n}{\circ}$ & $\stackrel{2}{i}$ & $\stackrel{+}{n}$ & $\frac{m}{0}$ & $\stackrel{\text { fn }}{\circ}$ & : & กี & 菅 & $\begin{array}{l}0 \\
0 \\
0\end{array}$ & $\stackrel{2}{n} \frac{9}{0}$ \\
\hline 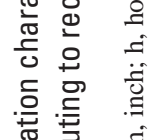 & 言 & $\stackrel{0}{\vec{N}} \stackrel{\circ}{\sim}$ & $\stackrel{+}{\vec{\lambda}}$ & $\vec{r}$ aे & aे & ชู & $\stackrel{\Upsilon}{I}$ & ֻุ & $\stackrel{n}{n}$ & $\stackrel{0}{\infty}$ & $\hat{\sigma}$ & $\ddot{\ddot{\theta}}$ & $\begin{array}{c}1 \\
\infty \\
\infty \\
\infty\end{array}$ & $\stackrel{?}{=}$ & $\stackrel{\leftrightarrow}{\dot{m}}$ & فे & $\stackrel{\circ}{\dot{I}}$ & 7 & $\stackrel{\text { त. }}{r}$ & $\stackrel{\circ}{\varrho}$ & $\stackrel{\text { I }}{I}$ & ते & $\exists$ & $\vec{\infty}=$ \\
\hline 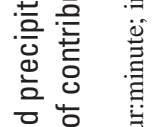 & 豈名豆 & $\stackrel{\circ}{\ddot{\Xi}} \stackrel{n}{\dddot{a}}$ & $\stackrel{n}{\ddot{m}}$ & $\begin{array}{l}\stackrel{n}{\stackrel{7}{0}} \\
\stackrel{g}{8}\end{array}$ & 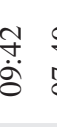 & 暠 & 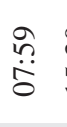 & $\begin{array}{l}\stackrel{\oplus}{n} \\
\stackrel{n}{n}\end{array}$ & 它 & $\begin{array}{l}\tilde{\Xi} \\
\dot{\Xi}\end{array}$ & ஸ̂. & $\begin{array}{lc}\overline{\dot{d}} & f \\
\dot{\sim} & \dot{\gamma}\end{array}$ & & $\begin{array}{l}\stackrel{n}{\dddot{m}} \\
\ddot{m}\end{array}$ & 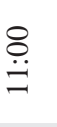 & $\begin{array}{l}8 \\
\dot{g}\end{array}$ & $\begin{array}{l}\stackrel{\leftrightarrow}{\dot{0}} \\
\dot{0}\end{array}$ & 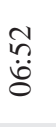 & $\stackrel{\stackrel{\infty}{n}}{\stackrel{\Xi}{J}}$ & $\begin{array}{l}\underset{8}{0} \\
\dot{\infty}\end{array}$ & $\begin{array}{l}8 \\
\dot{8}\end{array}$ & 華 & & $\begin{array}{ll}a & 8 \\
\dot{d} & \dot{d}\end{array}$ \\
\hline 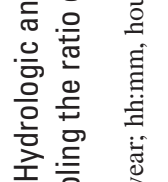 & 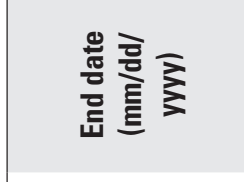 & 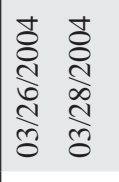 & 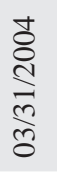 & 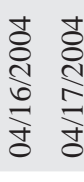 & 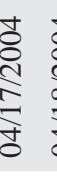 & 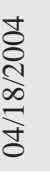 & 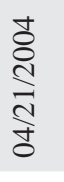 & 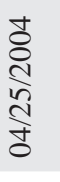 & & 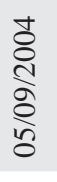 & 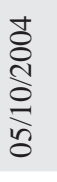 & 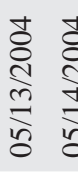 & 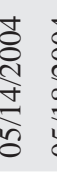 & 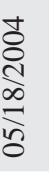 & 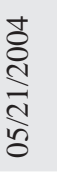 & 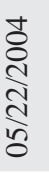 & 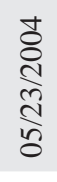 & 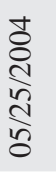 & 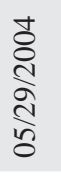 & 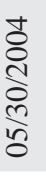 & 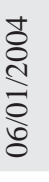 & 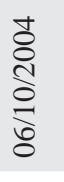 & 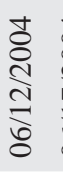 & 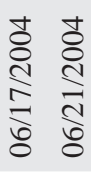 \\
\hline 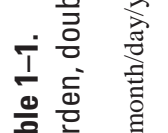 & 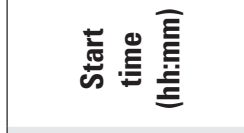 & 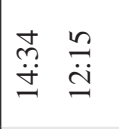 & $\underset{\stackrel{g}{+}}{\ddot{n}}$ & 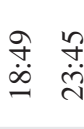 & 守 & ?ִ & $\begin{array}{l}\stackrel{f}{\dot{\Xi}} \\
\dot{I}\end{array}$ & $\frac{\dot{\theta}}{\ddot{\theta}}$ & $\stackrel{\overbrace{}}{\varrho}$ & $\stackrel{\check{n}}{\ddot{n}}$ & 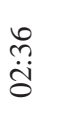 & 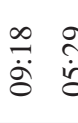 & $\begin{array}{l}\text { ते } \\
\ddot{b}\end{array}$ & & 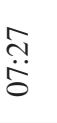 & 占 & $\stackrel{\stackrel{n}{\triangleq}}{=}$ & $\begin{array}{l}\text { fy } \\
\dot{8}\end{array}$ & 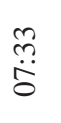 & 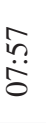 & $\begin{array}{l}\mathscr{n} \\
\ddot{8}\end{array}$ & ڤֶ̆ & & $\begin{array}{ll}\stackrel{N}{n} & \tilde{n} \\
\stackrel{\leftrightarrow}{*} & \ddot{\theta}\end{array}$ \\
\hline 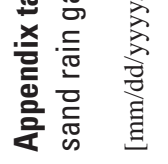 & 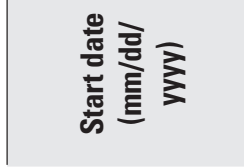 & 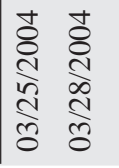 & 兽 & 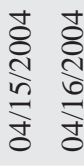 & 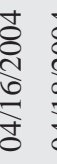 & 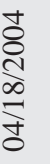 & 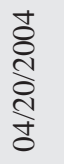 & 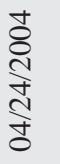 & 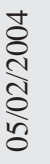 & 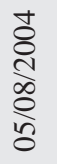 & 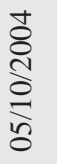 & 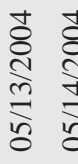 & 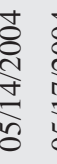 & $\frac{\substack{c \\
\frac{1}{5}}}{\frac{\pi}{5}}$ & 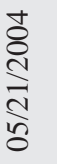 & 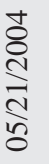 & है & 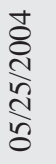 & 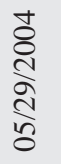 & 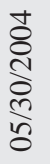 & $\begin{array}{l}\frac{ \pm}{8} \\
\stackrel{d}{\vdots} \\
\frac{m}{2}\end{array}$ & 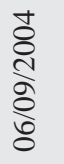 & 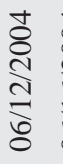 & 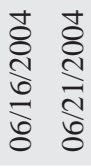 \\
\hline
\end{tabular}




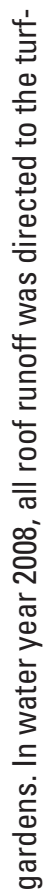

$\cdot \frac{\bar{E}}{\bar{\pi}}$

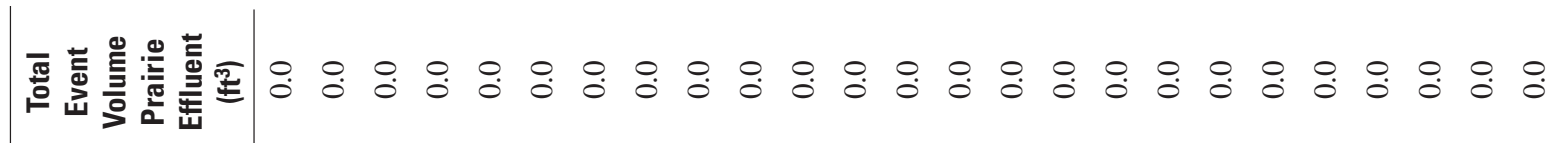

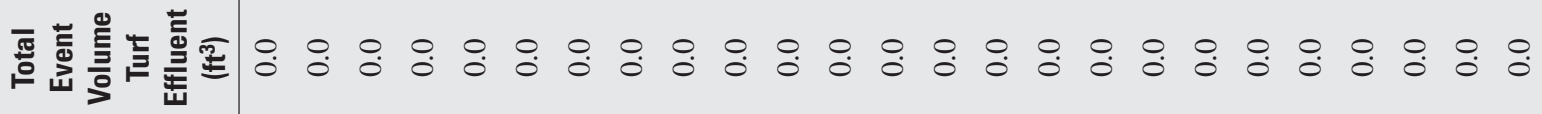

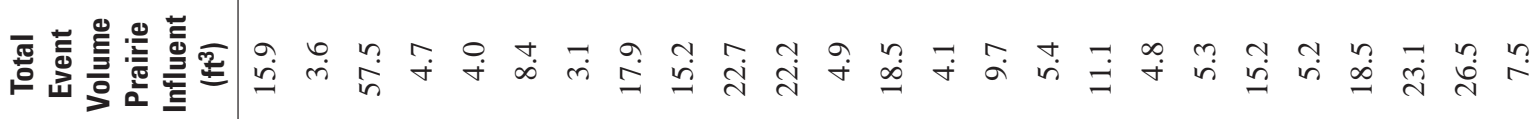

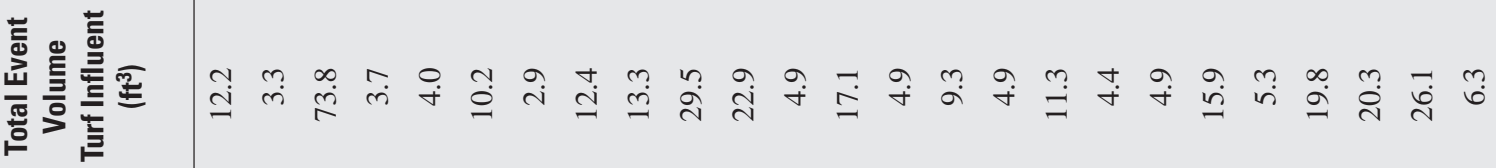
흔

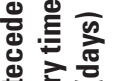

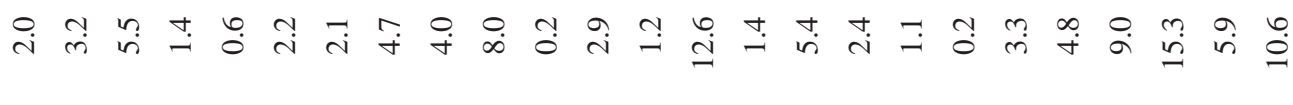
ت

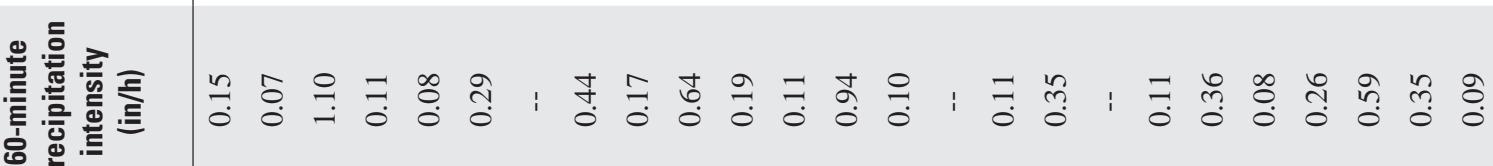
至 (1)

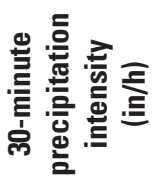

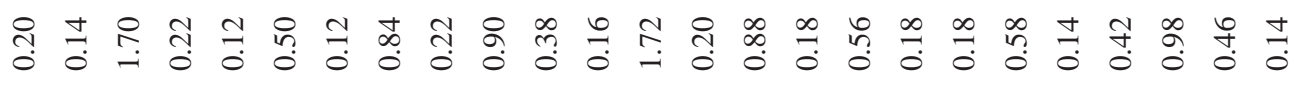

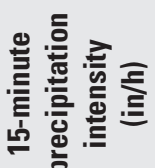

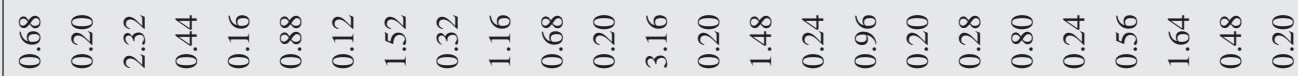

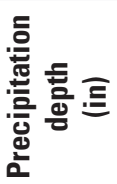

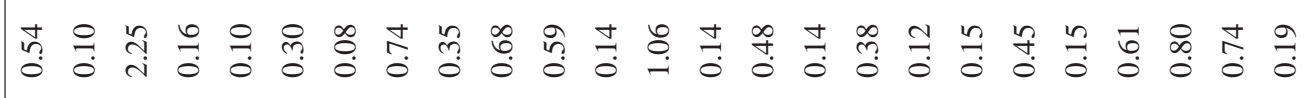

产要

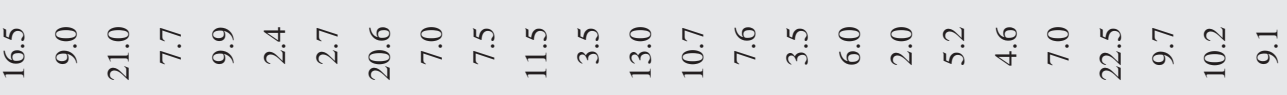

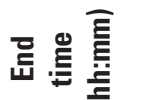

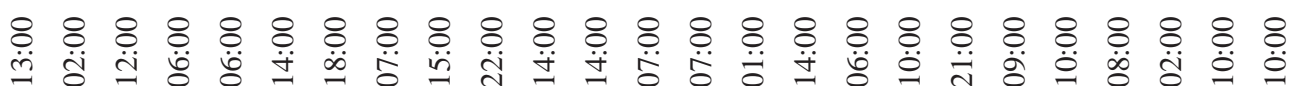

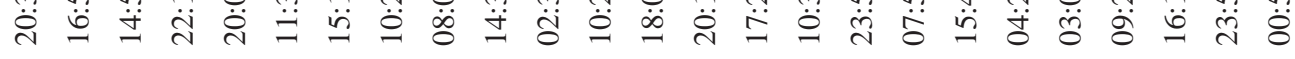




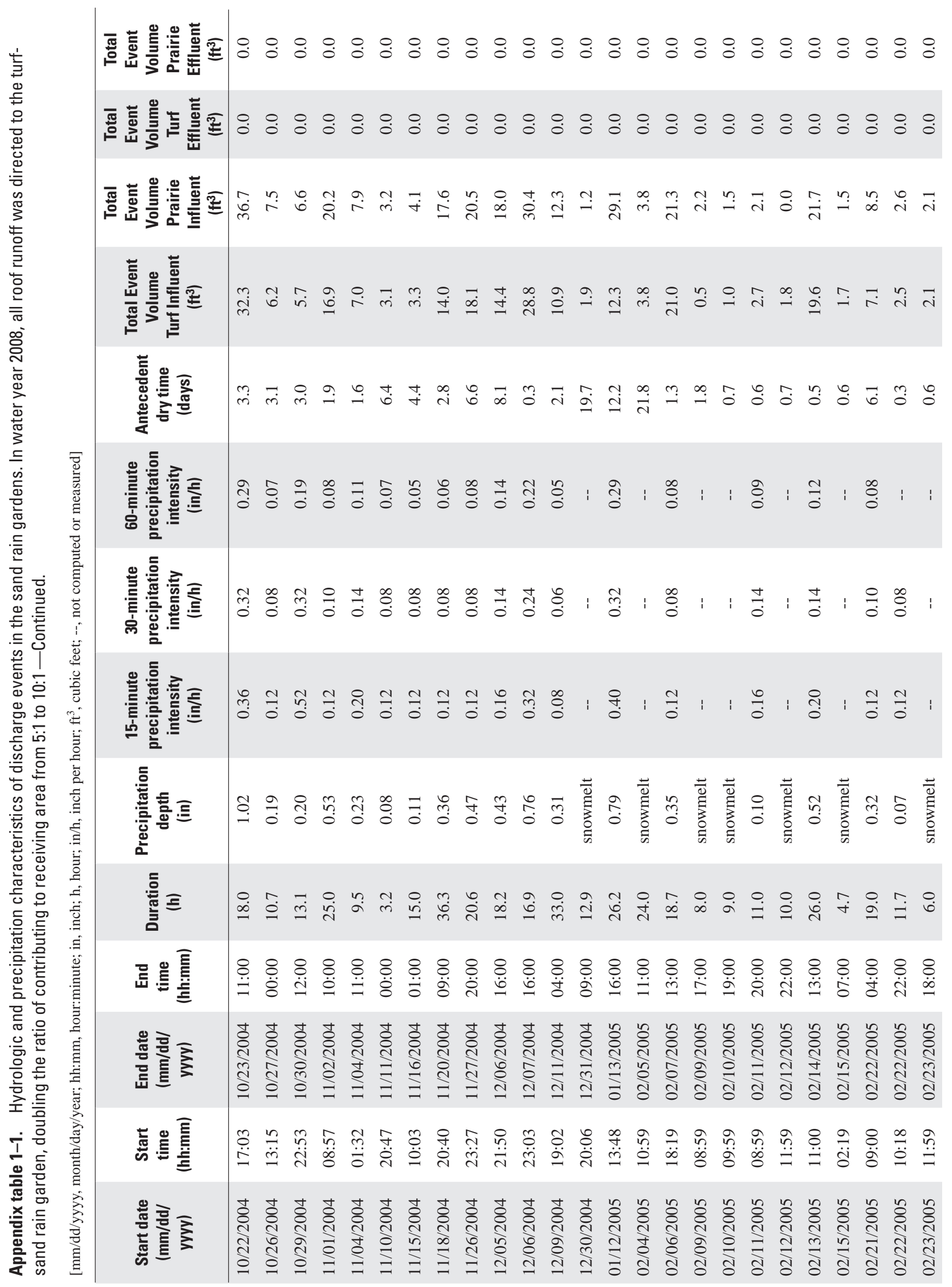




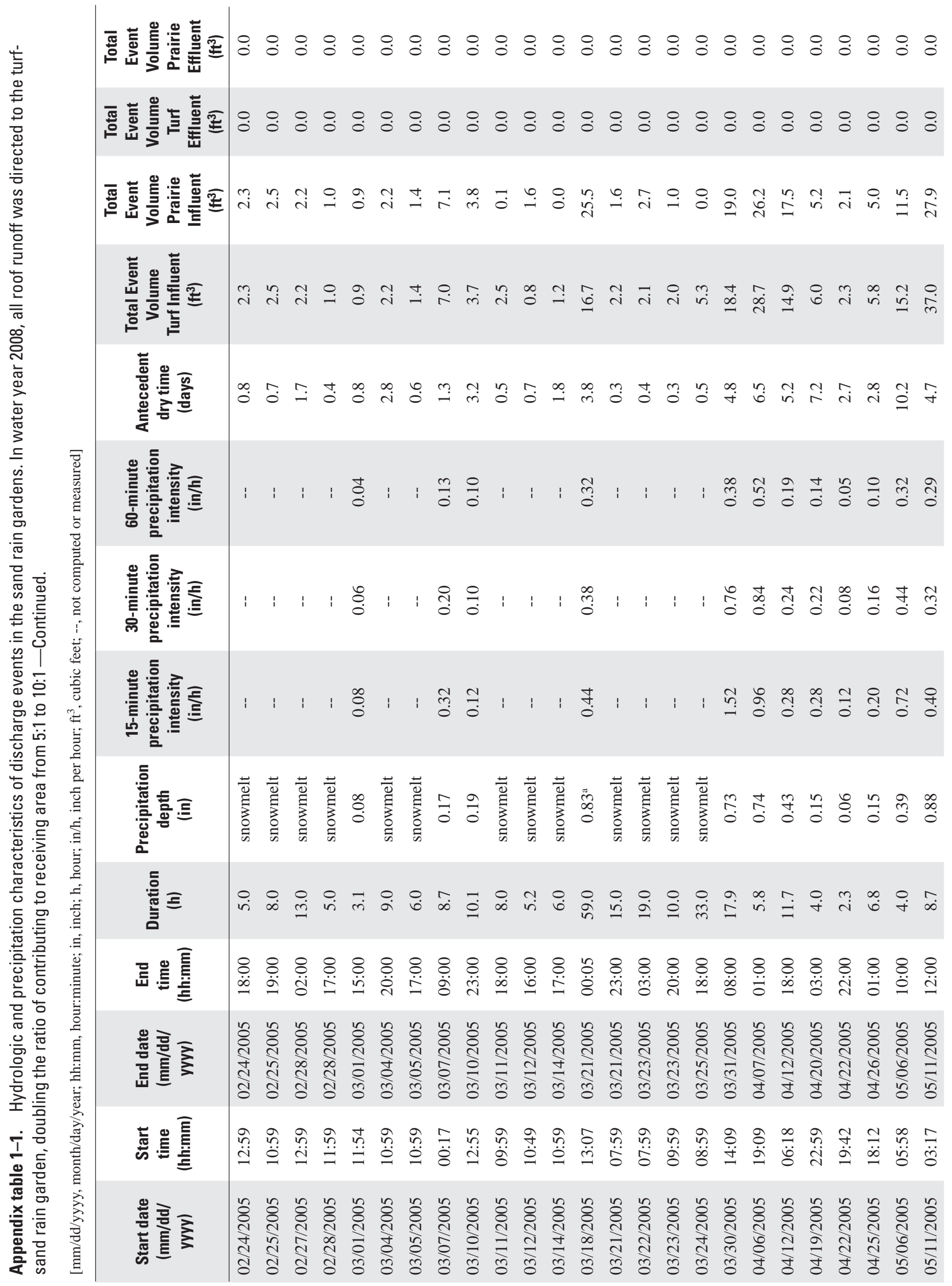




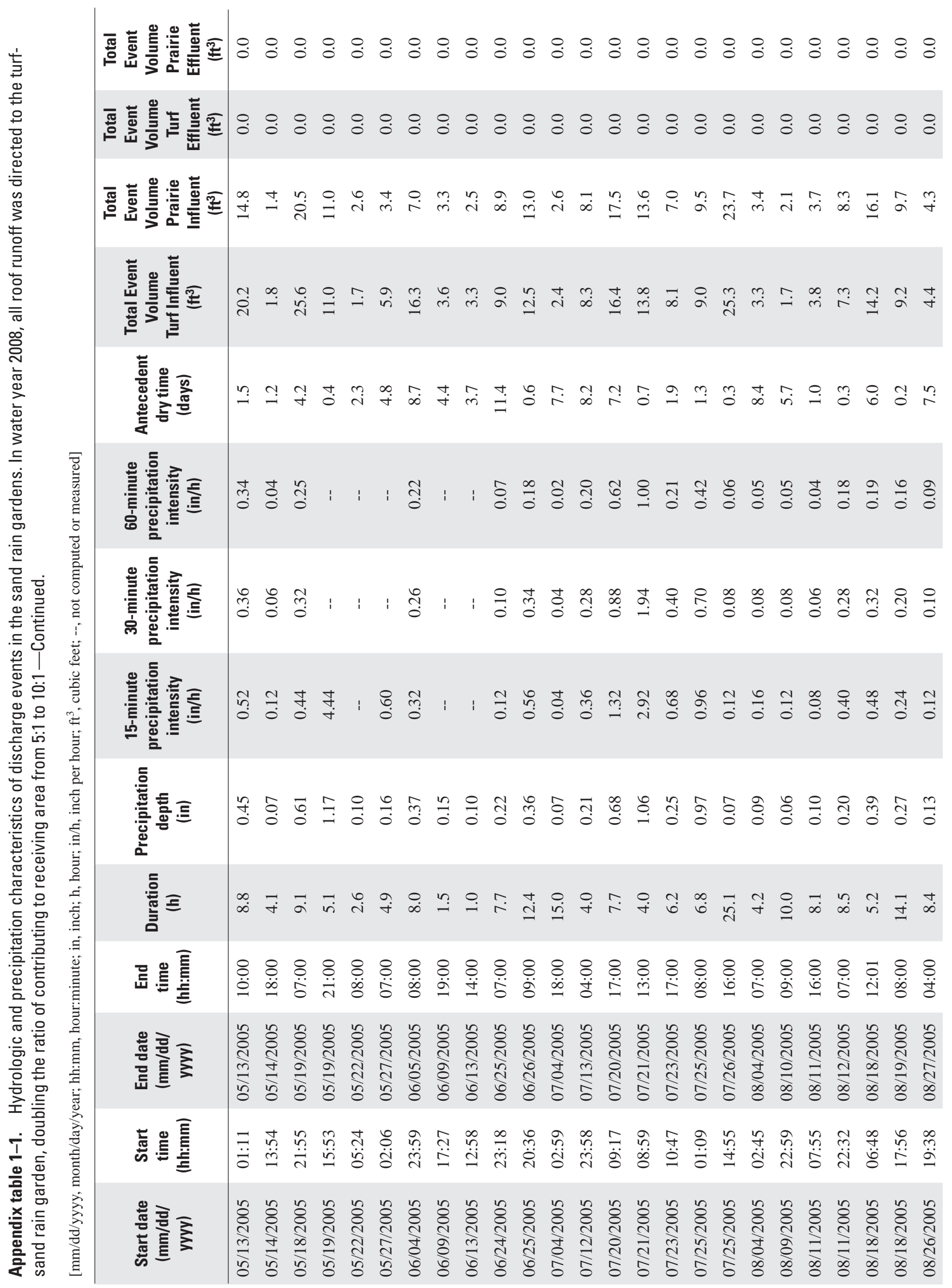




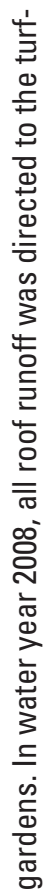

- 든

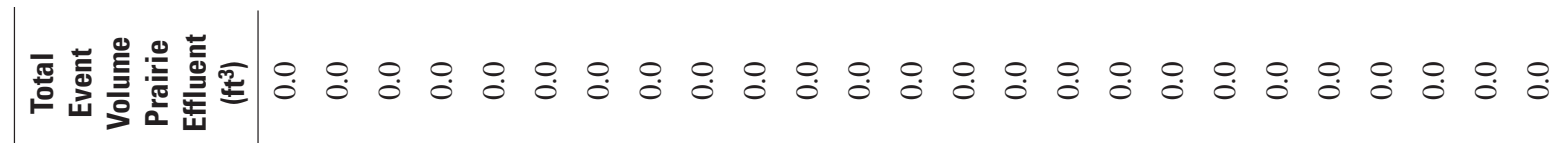

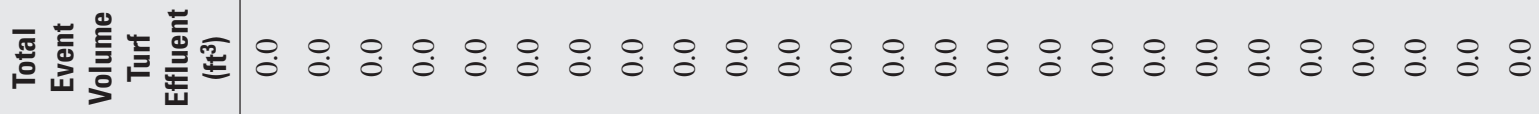

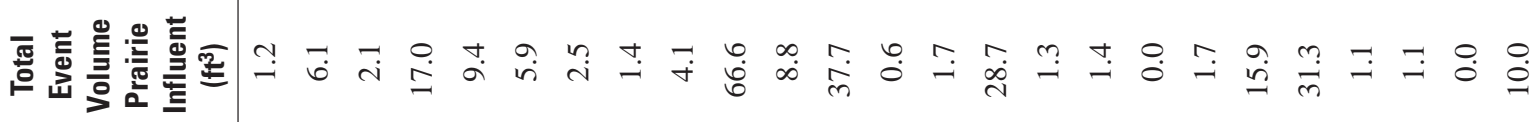

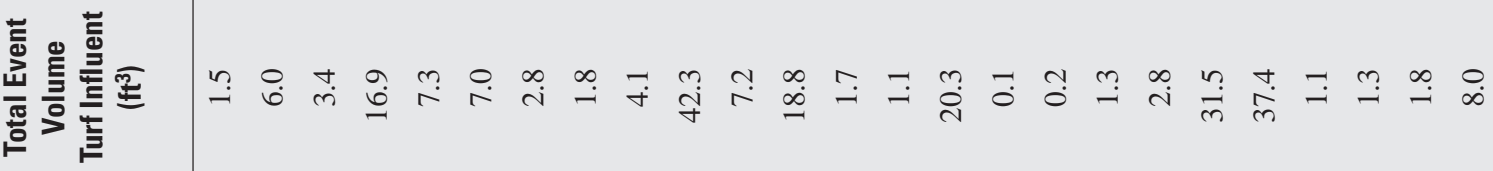
言

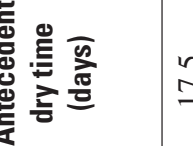

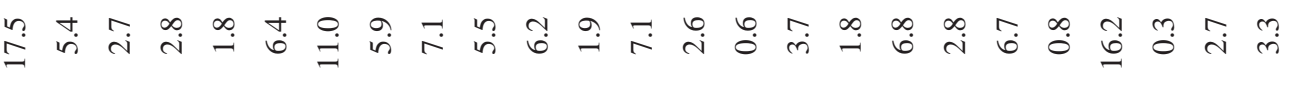

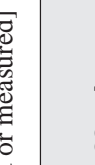

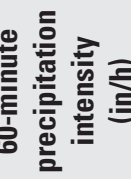

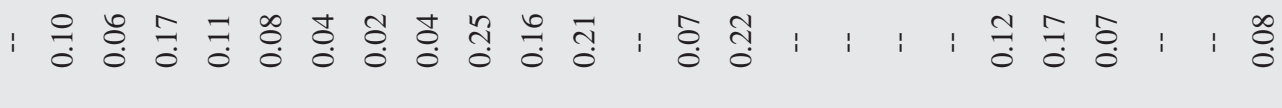

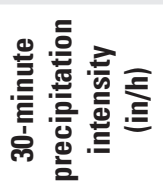

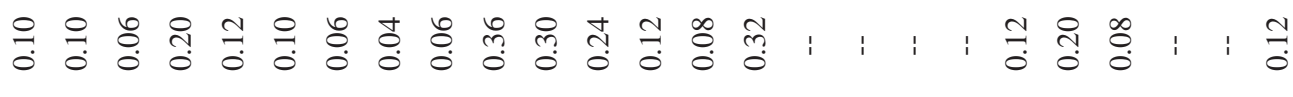

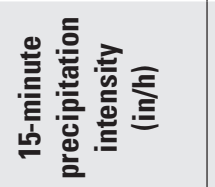

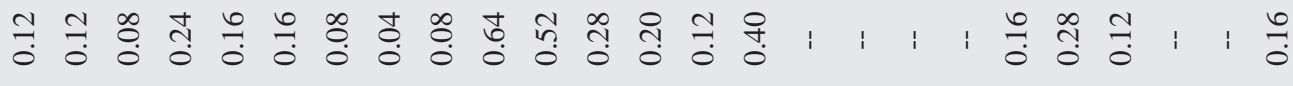
高

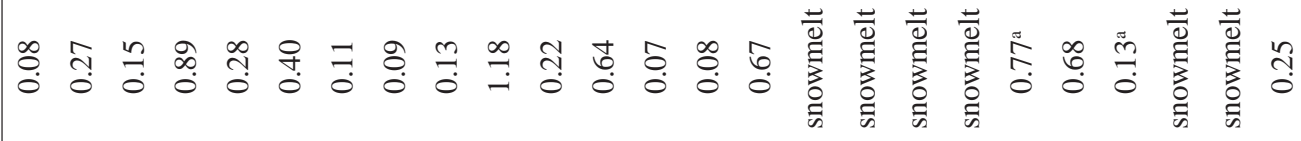

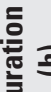

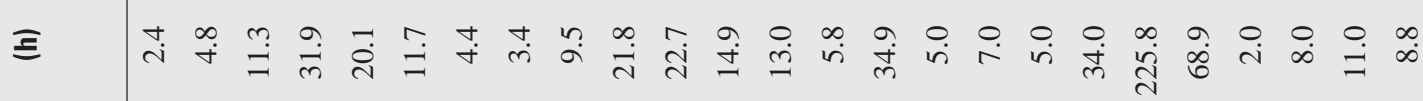
焉量垔

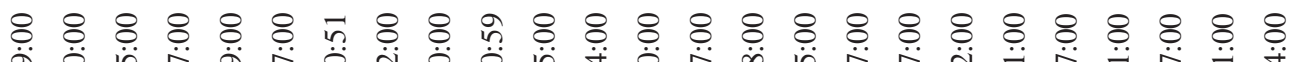

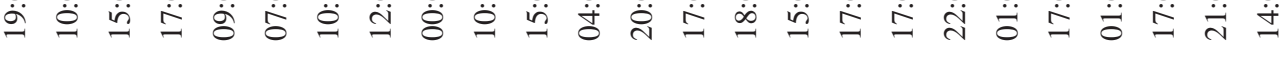

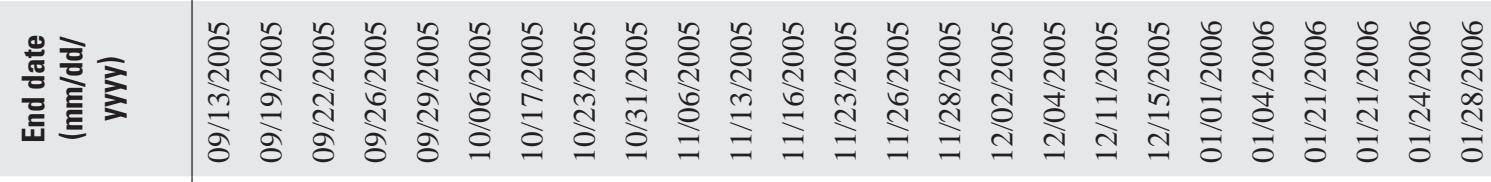
喜邑高 $\infty$ 궁

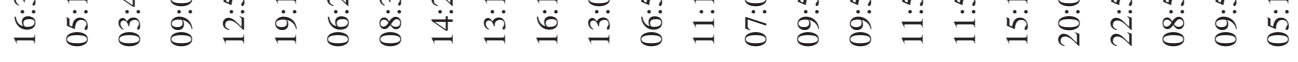

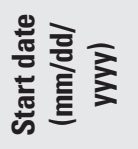

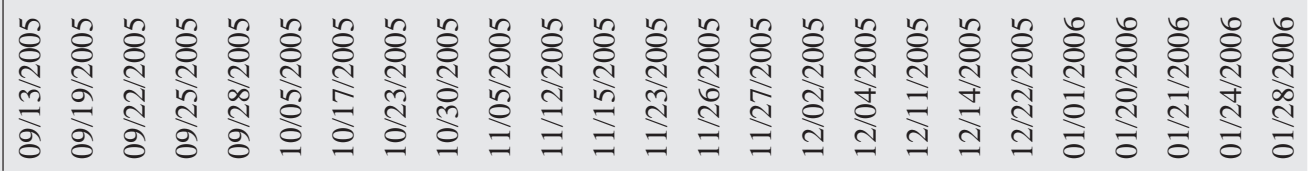




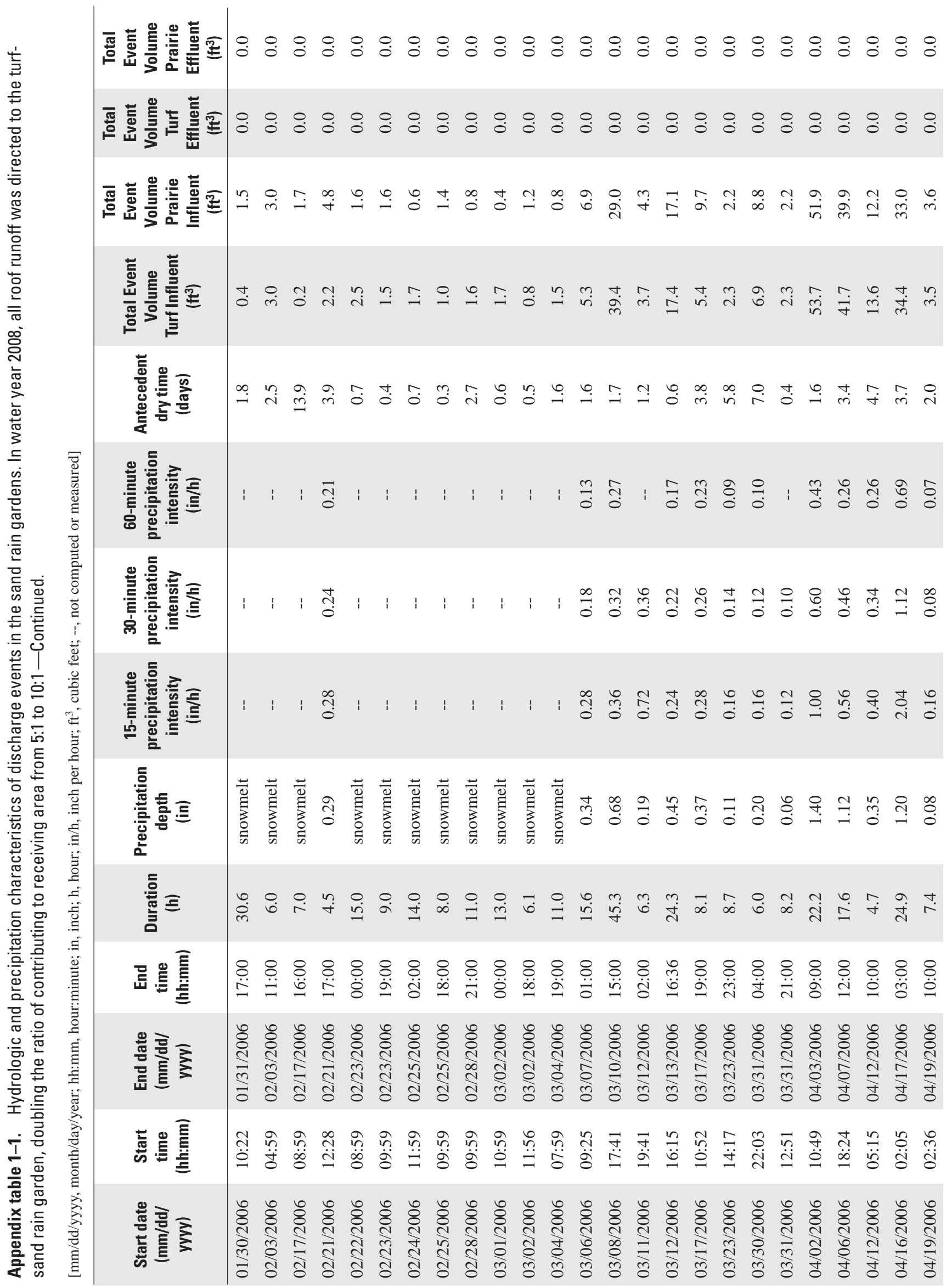




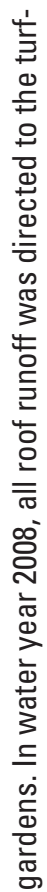

$\cdot \frac{\bar{E}}{\bar{\pi}}$

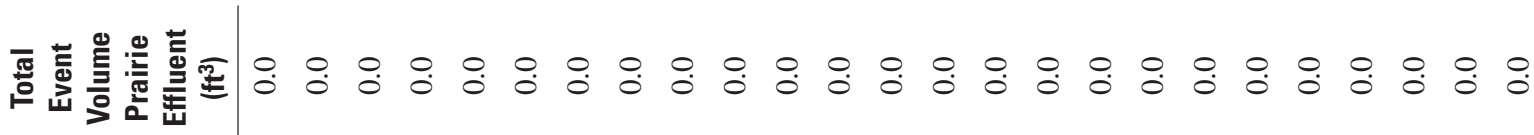

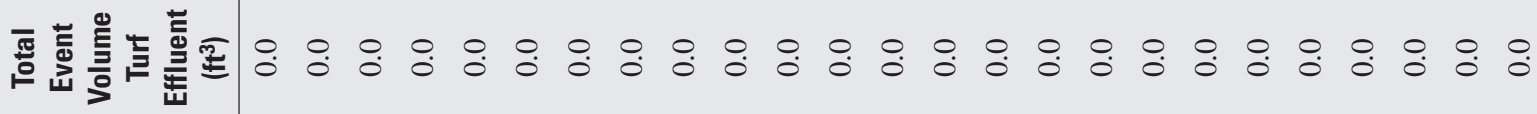

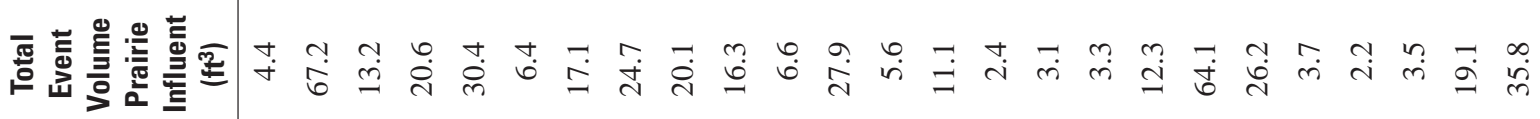

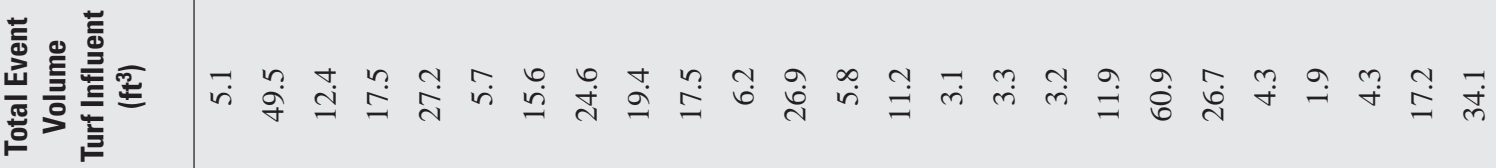
흔

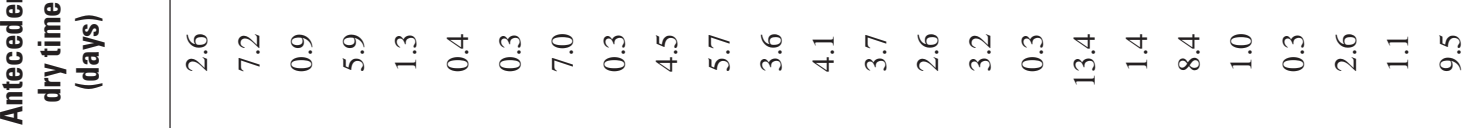

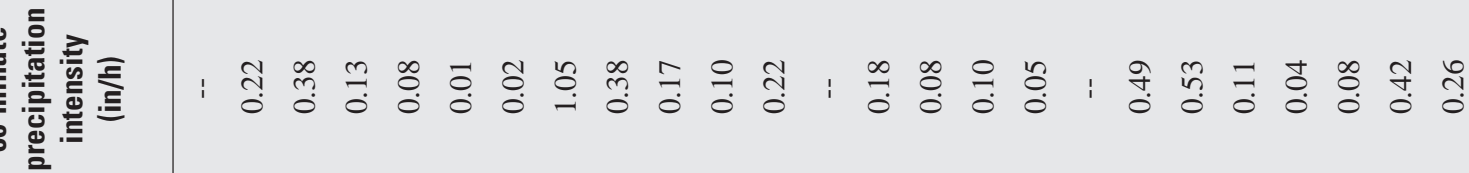
흘 角 西 产.

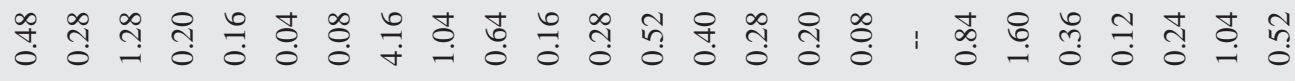

(2)

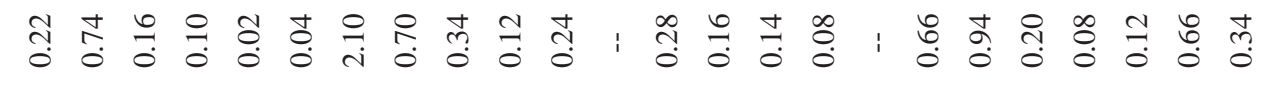
产言要

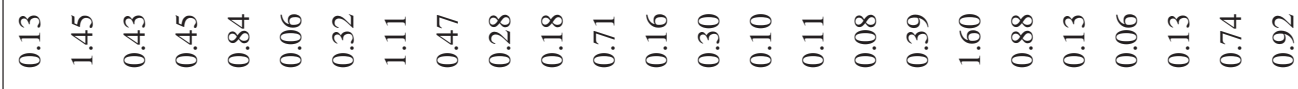

항

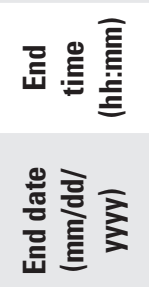

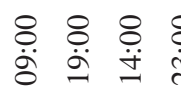
\& 8

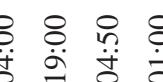
$\stackrel{8}{\because} \stackrel{8}{=}$

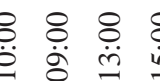

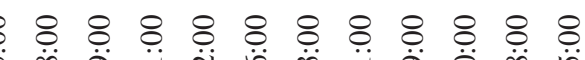

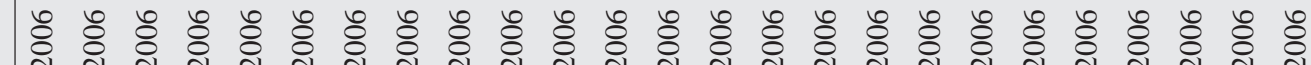

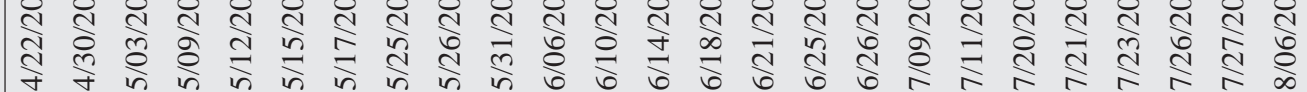

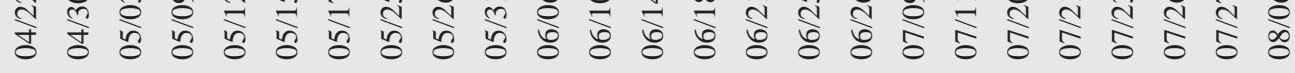




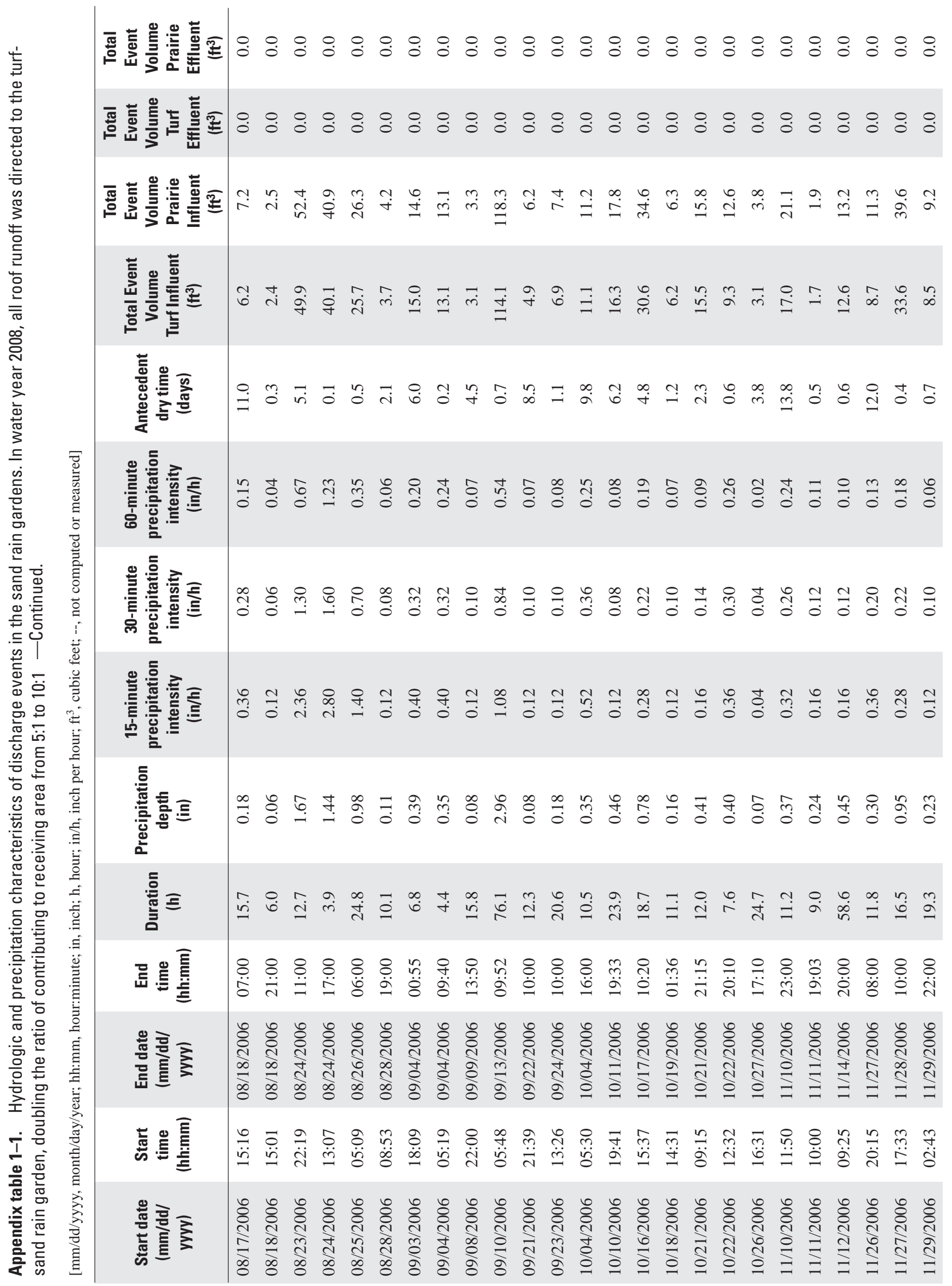




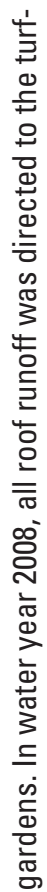

$\stackrel{\frac{5}{\pi}}{\frac{5}{\sigma}}$

它

|

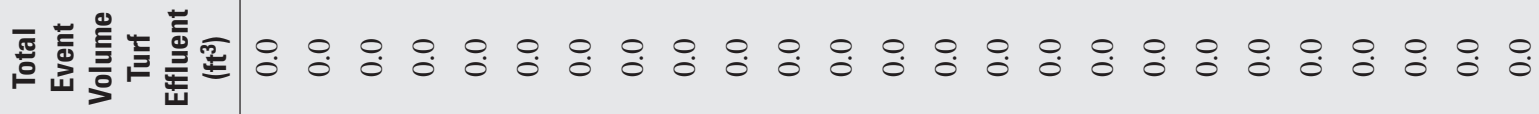

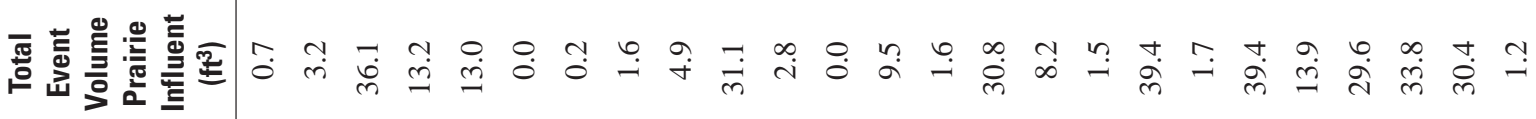

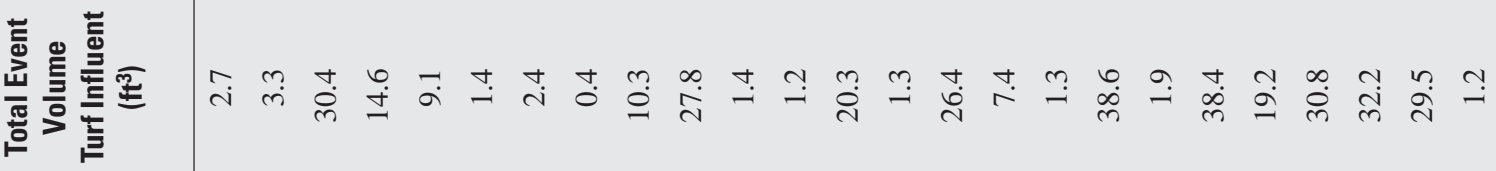
흘 递竞离

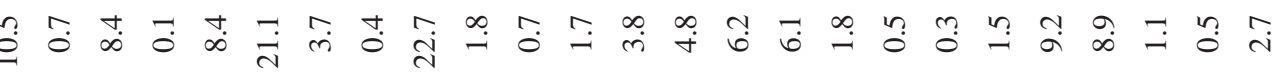

흘

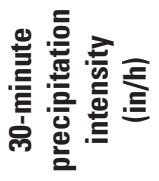

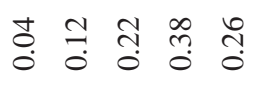

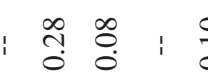

$\stackrel{\circ}{\circ}:$

กิ

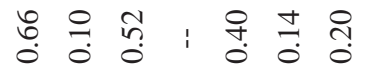

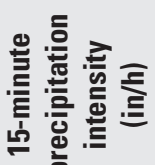

\pm+4 이

10

3

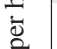

产言言要

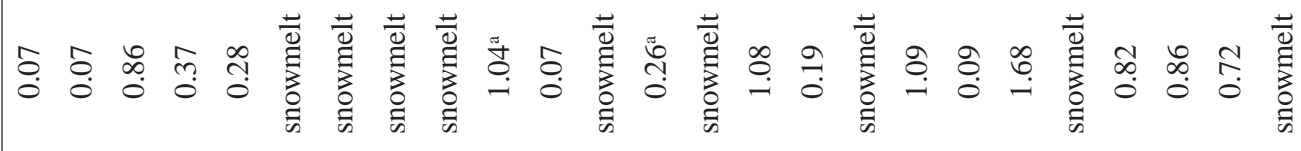

흐를

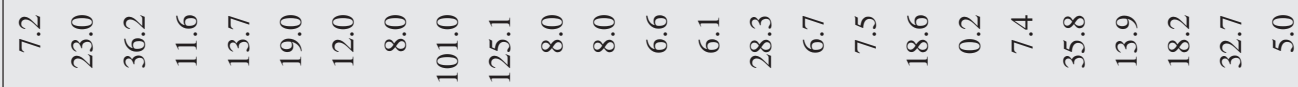

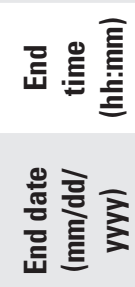

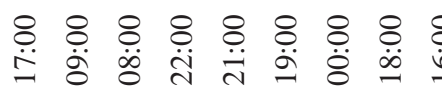

$\stackrel{8}{8}$

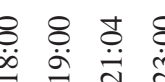

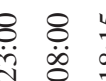

$\ddot{\infty} \stackrel{n}{\circ}$

\&

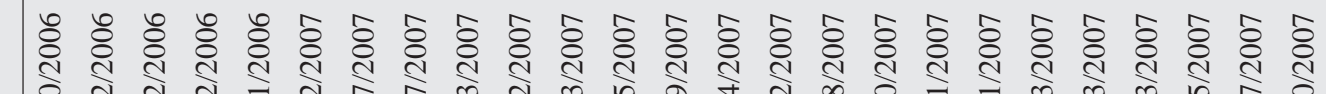

○

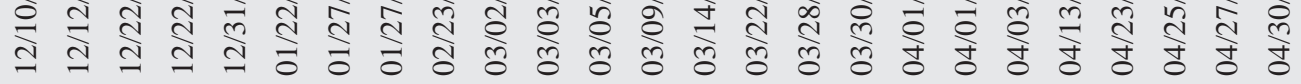

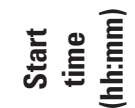

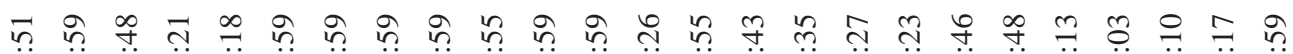

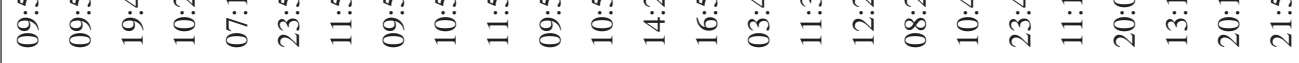




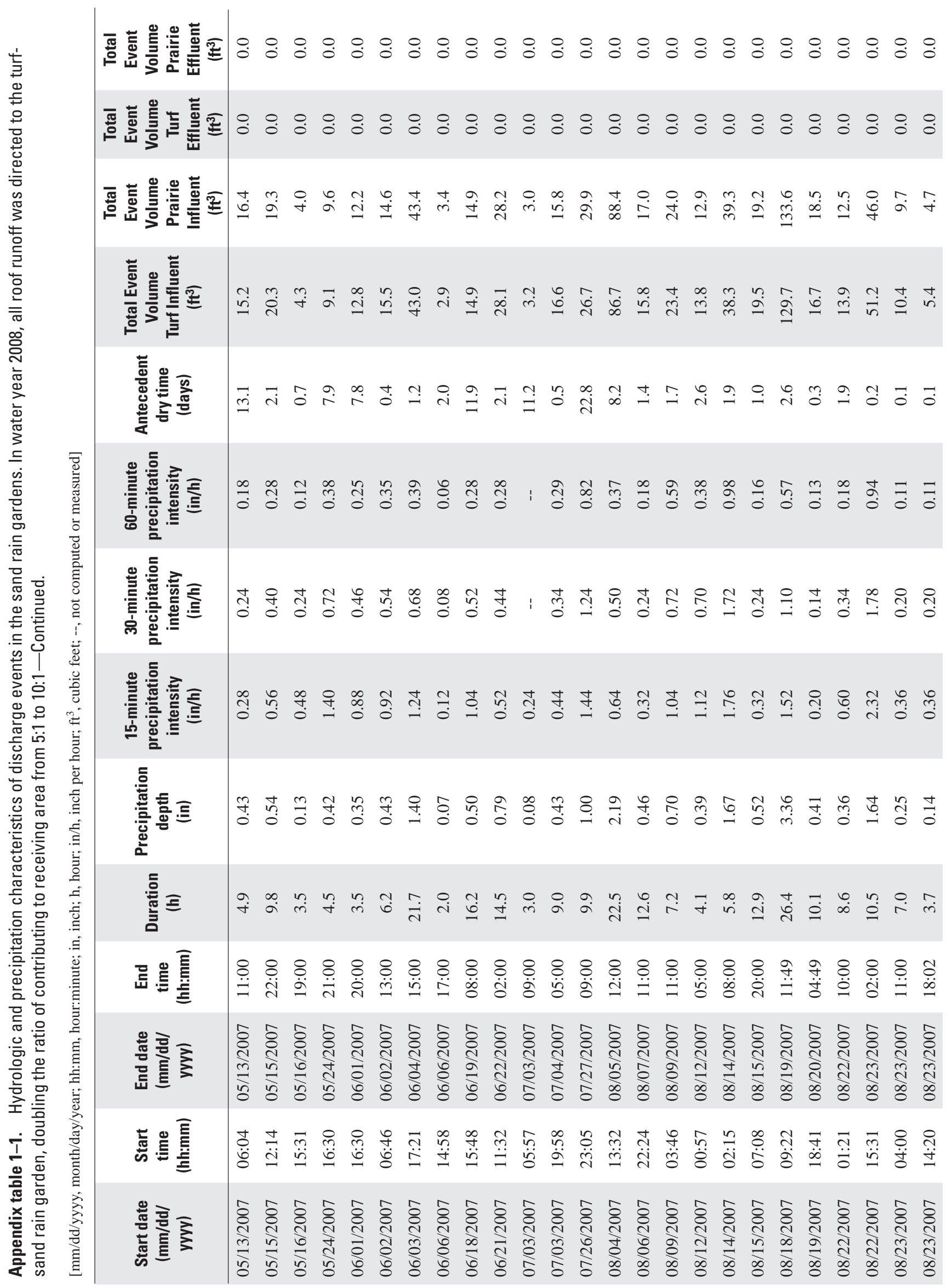




\begin{tabular}{|c|c|c|c|c|c|c|c|c|c|c|c|c|c|c|c|c|c|c|c|c|c|c|c|c|c|c|}
\hline$\frac{1}{\grave{t}}$ & 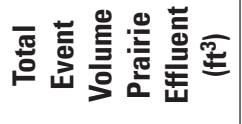 & $\stackrel{0}{\circ}$ & & $\stackrel{0}{0}$ & $\stackrel{0}{0}$ & $\stackrel{0}{0}$ & $\stackrel{0}{0}$ & $\stackrel{0}{\circ}$ & $\stackrel{0}{0}$ & 1 & I & i & i & i & 1 & i & I & i & I & 1 & i & i & I & i & 1 & i \\
\hline 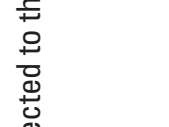 & 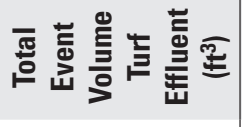 & $\stackrel{\circ}{\circ}$ & $\stackrel{0}{0}$ & $\stackrel{\circ}{\circ}$ & $\stackrel{0}{0}$ & $\stackrel{0}{0}$ & $\stackrel{0}{\circ}$ & $\stackrel{0}{0}$ & $\stackrel{0}{0}$ & $\stackrel{\circ}{\circ}$ & $\stackrel{\circ}{\circ}$ & $\stackrel{\circ}{0}$ & $\stackrel{\circ}{\circ}$ & $\stackrel{0}{0}$ & $\stackrel{0}{0}$ & $\stackrel{\circ}{\circ}$ & $\stackrel{0}{\circ}$ & $\stackrel{0}{0}$ & $\stackrel{0}{0}$ & $\stackrel{0}{\circ}$ & $\stackrel{0}{0}$ & $\stackrel{0}{\circ}$ & $\stackrel{0}{0}$ & $\stackrel{0}{0}$ & $\stackrel{0}{0}$ & $\stackrel{\circ}{0}$ \\
\hline 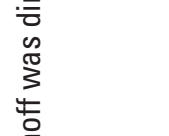 & 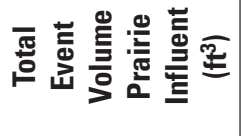 & $\stackrel{n}{\stackrel{n}{d}}$ & $\stackrel{\sim}{a}$ & $\vec{\infty}$ & $\underset{\infty}{-\infty}$ & $\begin{array}{l}n \\
n \\
m\end{array}$ & $\stackrel{\widehat{\jmath}}{\mathrm{c}}$ & $\begin{array}{l}\infty \\
\infty \\
\infty\end{array}$ & $\overrightarrow{0}$ & i & i & i & i & i & i & i & i & i & i & i & ! & i & i & 1 & i & i \\
\hline 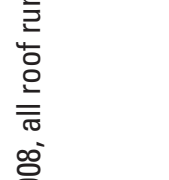 & 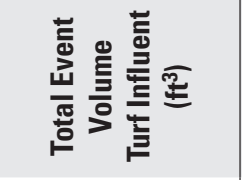 & 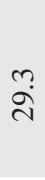 & $\frac{\nabla}{\Delta}$ & $\stackrel{a}{\infty}$ & $\stackrel{\infty}{\stackrel{\infty}{=}}$ & बें & $\stackrel{\widehat{c}}{\mathrm{c}}$ & $\stackrel{+}{\sim}$ & $\frac{a}{m}$ & $\stackrel{\infty}{\infty}$ & $\stackrel{+}{\forall}$ & nֶ. & $\begin{array}{l}0 \\
\qquad\end{array}$ & ণ̋ & $\stackrel{+}{\mathrm{i}}$ & $\stackrel{\sim}{\infty}$ & $\vec{a}$ & $\stackrel{\circ}{r}$ & $\stackrel{+}{i}$ & छి & İ & $\stackrel{n}{n}$ & $\stackrel{?}{+}$ & $\vec{m}$ & $\stackrel{\infty}{\sim}$ & $\stackrel{n}{n}$ \\
\hline 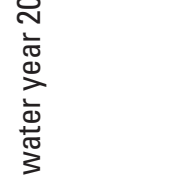 & 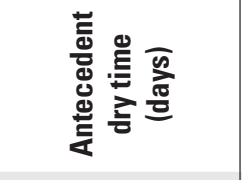 & $\stackrel{+}{\circ}$ & $\stackrel{n}{0}$ & $\begin{array}{l}o \\
\stackrel{i}{ }\end{array}$ & 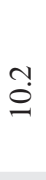 & $\stackrel{a}{i}$ & $\stackrel{n}{\varrho}$ & $\stackrel{n}{n}$ & $\stackrel{n}{\gamma}$ & $\stackrel{\sim}{-}$ & $\stackrel{r}{n}$ & $n$ & $\stackrel{\infty}{\circ}$ & $\stackrel{+}{-}$ & $\stackrel{0}{0}$ & $\frac{\sigma}{m}$ & $?$ & ウे & $\ddot{0}$ & $\stackrel{\circ}{\stackrel{1}{\prime}}$ & $\stackrel{n}{\simeq}$ & $\stackrel{+}{\sim}$ & $\tilde{0}$ & $\stackrel{\infty}{i}$ & $\hat{\sigma}$ & $\stackrel{a}{n}$ \\
\hline 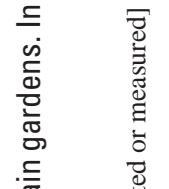 & 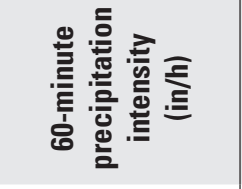 & $\stackrel{m}{0}$ & ñ? & 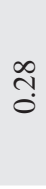 & 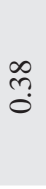 & กุ & ơ & $\frac{0}{0}$ & ָָ & ઼ָ & i & $\stackrel{2}{\circ}$ & $\frac{0}{0}$ & $\stackrel{\infty}{+}$ & 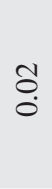 & $\begin{array}{l}\dot{0} \\
0\end{array}$ & $\stackrel{0}{0}$ & $\stackrel{\text { ๖े }}{\circ}$ & I & 1 & ! & i & i & i & $\stackrel{0}{0}$ & $\stackrel{8}{\circ}$ \\
\hline 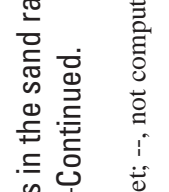 & 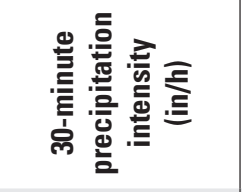 & $\begin{array}{l}\infty \\
\infty \\
0\end{array}$ & $\stackrel{\infty}{=}$ & กֶ & $\stackrel{+}{\stackrel{0}{0}}$ & ஸे & $\begin{array}{l}0 \\
0 \\
0\end{array}$ & 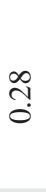 & లె & $\stackrel{+}{+}$ & $i$ & $\stackrel{\infty}{\circ}$ & ָֻ & $\stackrel{8}{\stackrel{8}{0}}$ & $\begin{array}{l}\dot{0} \\
\dot{0}\end{array}$ & 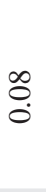 & $\begin{array}{l}\dot{\Xi} \\
\stackrel{0}{0}\end{array}$ & $\stackrel{\infty}{\circ}$ & 1 & 1 & i & 1 & 1 & i & $\stackrel{\infty}{0}$ & $\stackrel{\infty}{0}$ \\
\hline 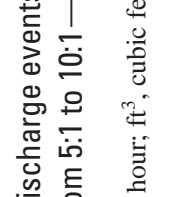 & 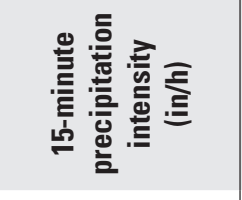 & $\stackrel{+}{\stackrel{ \pm}{-}}$ & నૂ & $\stackrel{\infty}{\stackrel{\infty}{0}}$ & $\stackrel{\overbrace{}}{\dddot{n}}$ & $\stackrel{\infty}{\stackrel{\infty}{0}}$ & $\stackrel{8}{\stackrel{8}{\circ}}$ & ?ొ & $\stackrel{0}{\circ}$ & $\stackrel{0}{\infty}$ & i & $\frac{1}{0}$ & ?ֶ? & $\stackrel{+}{\infty}$ & $\stackrel{\Xi}{\stackrel{\Xi}{0}}$ & $\frac{N}{0}$ & $\stackrel{\Xi}{\stackrel{\Xi}{0}}$ & $\frac{N}{0}$ & i & i & i & i & i & i & $\frac{N}{0}$ & $\frac{1}{0}$ \\
\hline 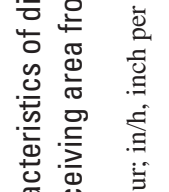 & 을 & $\underset{\dot{0}}{\stackrel{t}{0}}$ & 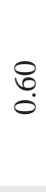 & $\stackrel{\infty}{+}$ & $\vec{\sigma}$ & oু & $\begin{array}{l}\underset{J}{t} \\
\stackrel{0}{0}\end{array}$ & ָิ & $\stackrel{N}{\infty}$ & $\stackrel{\infty}{+}$ & $\bar{\Xi}$ & $\stackrel{\widetilde{N}}{0}$ & $\stackrel{\text { In }}{\circ}$ & $\stackrel{\overbrace{}}{\sim}$ & $\stackrel{0}{0}$ & $\frac{\infty}{0}$ & 웅 & $\frac{9}{0}$ & 离 & 莺 & 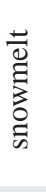 & 离 & 离 & 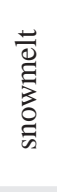 & i̊n. & तี \\
\hline 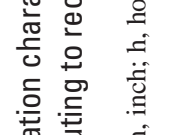 & 흘 & $\vec{\infty}$ & $n$ & 尹̈ & $\begin{array}{l}\text { 무 } \\
\ddot{n}\end{array}$ & $\vec{n}$ & 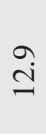 & $\stackrel{\bullet}{\circ}$ & $\stackrel{m}{ \pm}$ & $\begin{array}{l}0 \\
\stackrel{1}{0}\end{array}$ & $\stackrel{9}{-}$ & $\overrightarrow{\tilde{N}}$ & $\begin{array}{l}0 \\
\stackrel{\varphi}{ }\end{array}$ & $\stackrel{\sim}{\sim}$ & ָ̃ & $\stackrel{n}{ \pm}$ & $\begin{array}{l}\infty \\
\dot{n}\end{array}$ & $\stackrel{i}{\check{C}}$ & $\dddot{n}$ & $\frac{\dot{\nabla}}{\sigma}$ & 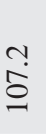 & $\stackrel{0}{\text { m }}$ & ڤิ) & $\frac{0}{\Delta}$ & $\stackrel{\sim}{q}$ & $\underset{\infty}{\infty}$ \\
\hline 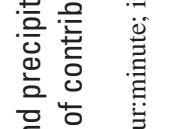 & 을 豆豆 & $\stackrel{8}{\stackrel{8}{\Xi}}$ & 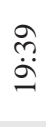 & $\begin{array}{l}\stackrel{8}{\circ} \\
\dot{\sim}\end{array}$ & $\begin{array}{l}\stackrel{8}{\circ} \\
\dot{\circ}\end{array}$ & $\begin{array}{l}\stackrel{8}{8} \\
\dot{\phi} \\
\dot{0}\end{array}$ & $\begin{array}{l}\stackrel{8}{0} \\
\dot{\infty} \\
\stackrel{0}{0}\end{array}$ & $\begin{array}{l}8 \\
\stackrel{\circ}{\circ}\end{array}$ & 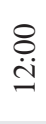 & $\underset{\stackrel{\infty}{\infty}}{\stackrel{\infty}{\circ}}$ & 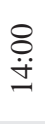 & $\begin{array}{l}\stackrel{8}{\dot{d}} \\
\dot{\sim}\end{array}$ & $\stackrel{8}{\stackrel{8}{\beth}}$ & $\begin{array}{l}\stackrel{8}{0} \\
\stackrel{0}{ }\end{array}$ & $\begin{array}{l}\stackrel{8}{\circ} \\
\dot{\sim}\end{array}$ & $\begin{array}{l}\stackrel{8}{\circ} \\
\text { ஸ் }\end{array}$ & $\stackrel{8}{\stackrel{0}{0}}$ & $\begin{array}{l}\stackrel{8}{\ddot{\infty}} \\
\stackrel{\infty}{-}\end{array}$ & $\begin{array}{l}\stackrel{8}{\mathrm{~d}} \\
\stackrel{\text { I }}{ }\end{array}$ & 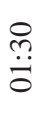 & $\frac{8}{\dot{\Xi}}$ & $\begin{array}{l}\stackrel{8}{\oplus} \\
\dot{\infty}\end{array}$ & ب̣ & 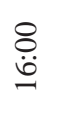 & $\begin{array}{l}8 \\
\stackrel{\leftrightarrow}{\mathscr{n}}\end{array}$ & $\begin{array}{l}\stackrel{8}{\ddot{\theta}} \\
\dot{\vartheta}\end{array}$ \\
\hline 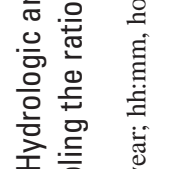 & 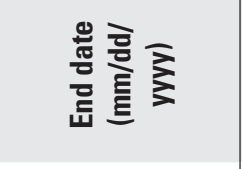 & 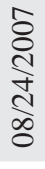 & 总 & 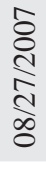 & 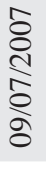 & 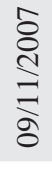 & 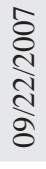 & 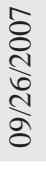 & 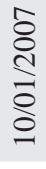 & 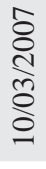 & 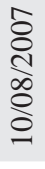 & 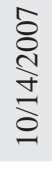 & 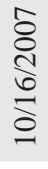 & $\begin{array}{c}\hat{\delta} \\
\substack{1 \\
\infty} \\
\vdots\end{array}$ & $\begin{array}{l}\hat{\delta} \\
\stackrel{1}{a} \\
\stackrel{2}{\vdots}\end{array}$ & 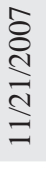 & 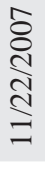 & 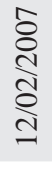 & 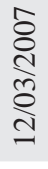 & 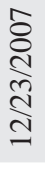 & 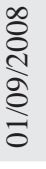 & $\begin{array}{l}\infty \\
\stackrel{\infty}{\$} \\
\vdots \\
\vdots \\
\vdots\end{array}$ & 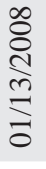 & 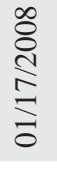 & 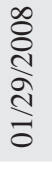 & 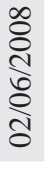 \\
\hline 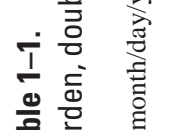 & 壱导言 & $\begin{array}{l}\stackrel{n}{\sigma} \\
\stackrel{\delta}{\delta}\end{array}$ & $\stackrel{\infty}{\stackrel{0}{0}}$ & $\begin{array}{l}n \\
\stackrel{n}{0} \\
\infty \\
0\end{array}$ & $\stackrel{n}{n}$ & \begin{tabular}{l}
\multirow{8}{8}{} \\
$\stackrel{8}{8}$
\end{tabular} & $\begin{array}{l}\infty \\
\stackrel{0}{\sigma}\end{array}$ & $\begin{array}{l}\overparen{\sim} \\
\stackrel{\sim}{\sim}\end{array}$ & $\underset{\stackrel{+}{ন}}{\stackrel{\nabla}{\sim}}$ & $\frac{I}{\check{I}}$ & $\begin{array}{l}\stackrel{8}{\circ} \\
\dot{I}\end{array}$ & $\begin{array}{l}\tilde{\sigma} \\
\check{\delta}\end{array}$ & $\stackrel{+}{\stackrel{+}{\sigma}}$ & 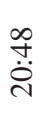 & $\begin{array}{l}\text { 安 } \\
\dot{8}\end{array}$ & $\stackrel{\mathscr{\vartheta}}{=}$ & $\stackrel{8}{\stackrel{0}{0}}$ & $\frac{\sigma}{\ddot{\delta}}$ & $\stackrel{m}{\varrho}$ & $\begin{array}{l}\hat{o} \\
\dot{I}\end{array}$ & $\begin{array}{l}\stackrel{a}{\dot{y}} \\
\ddot{n}\end{array}$ & $\stackrel{8}{\stackrel{8}{=}}$ & $\stackrel{\stackrel{ }{ }}{=}$ & $\begin{array}{l}8 \\
\dot{g} \\
\ddot{-}\end{array}$ & 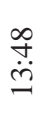 & $\begin{array}{l}\stackrel{8}{0} \\
\dot{\sim}\end{array}$ \\
\hline 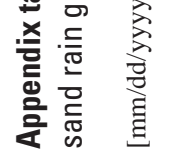 & 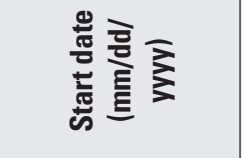 & 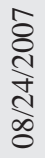 & 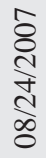 & 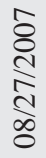 & $\begin{array}{l}\frac{5}{8} \\
\frac{1}{8} \\
\frac{8}{8}\end{array}$ & $\begin{array}{l}\hat{\delta} \\
\text { ㅇ } \\
\text { o } \\
\text { o }\end{array}$ & 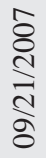 & $\begin{array}{l}\frac{5}{8} \\
\frac{1}{2} \\
\frac{\sqrt{2}}{8}\end{array}$ & 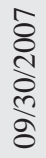 & 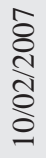 & 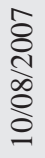 & 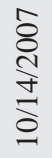 & $\begin{array}{l}\frac{\hat{8}}{8} \\
\frac{1}{2} \\
\vdots\end{array}$ & 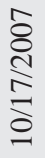 & 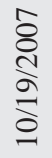 & $\begin{array}{l}\text { ô } \\
\text { d̦ } \\
\text { dิ } \\
\text { 三 }\end{array}$ & 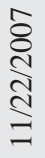 & 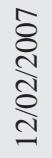 & 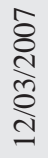 & 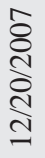 & 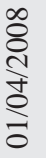 & 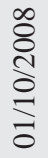 & 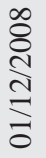 & 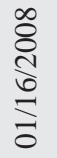 & & 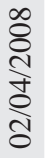 \\
\hline
\end{tabular}




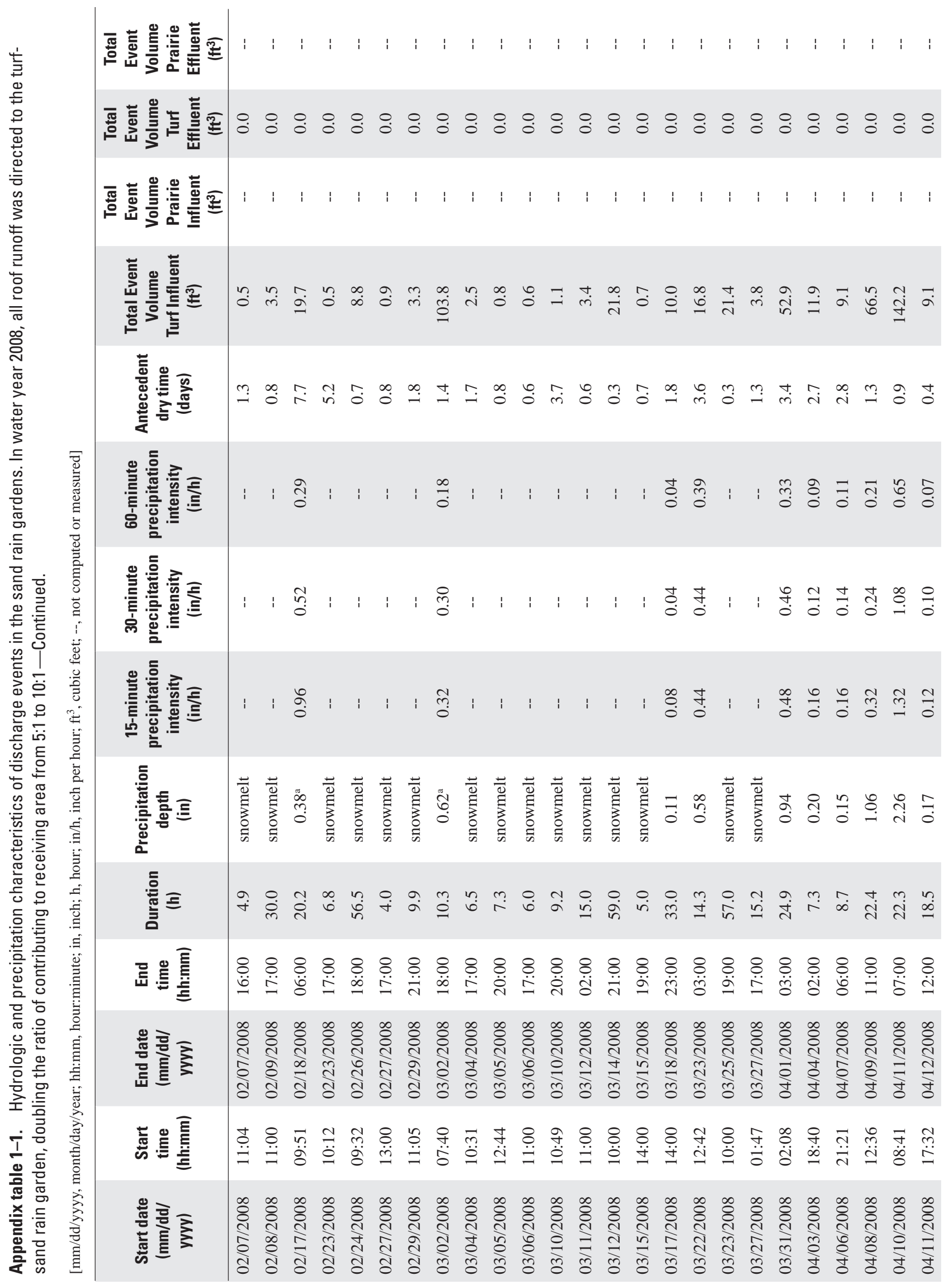




\begin{tabular}{|c|c|c|c|c|c|c|c|c|c|c|c|c|c|c|c|c|c|c|c|c|c|c|c|c|c|c|}
\hline$\stackrel{!}{\prime}$ & 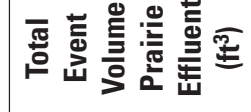 & i & & 1 & & & & & i & & & & & & & i & & i & i & i & i & i & i & i & i & \\
\hline 足 & 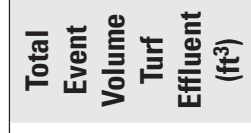 & $\stackrel{0}{0}$ & $\ddot{\circ}$ & $\stackrel{\circ}{\circ}$ & $\stackrel{\circ}{\circ}$ & $\stackrel{\circ}{\circ}$ & $\stackrel{0}{0}$ & $\stackrel{0}{0}$ & $\stackrel{\circ}{\circ}$ & & 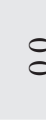 & & & & & $\stackrel{\circ}{\circ}$ & $\stackrel{0}{\circ}$ & $\stackrel{n}{=}$ & $\stackrel{\circ}{\circ}$ & $\stackrel{0}{0}$ & $\stackrel{0}{0}$ & $\stackrel{0}{0}$ & $\stackrel{0}{\circ}$ & $\stackrel{0}{\circ}$ & $\stackrel{\leftrightarrow}{\circ}$ & \\
\hline 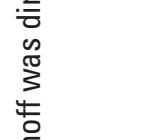 & 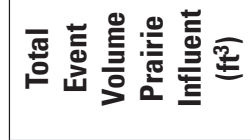 & i & i & i & ' & i & I & i & i & i & 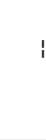 & & & i & i & i & i & i & i & i & i & i & i & i & i & i \\
\hline 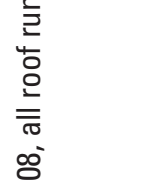 & 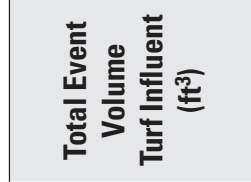 & $\begin{array}{l}0 \\
\dot{\sim} \\
\stackrel{\sim}{d}\end{array}$ & $\stackrel{b}{m}$ & $\stackrel{m}{m}$ & $\stackrel{n}{\varrho}$ & $\hat{i n}$ & $\overrightarrow{\mathrm{d}}$ & 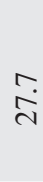 & $\vec{\AA}$ & $\stackrel{\rho}{\sigma}$ & 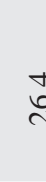 & & \% & & $e^{\circ}$ & $\vec{n}$ & $\stackrel{n}{\stackrel{n}{ \pm}}$ & $\begin{array}{l}\text { aे } \\
\text { in }\end{array}$ & $\begin{array}{l}\stackrel{\infty}{\varrho} \\
ٍ\end{array}$ & $\stackrel{\infty}{\stackrel{0}{\varrho}}$ & $\dot{m}$ & $\stackrel{\infty}{i}$ & $\stackrel{\infty}{r}$ & $\begin{array}{l}\infty \\
\text { గై }\end{array}$ & $\stackrel{n}{n}$ & $\stackrel{\rho}{=}$ \\
\hline 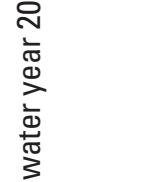 & 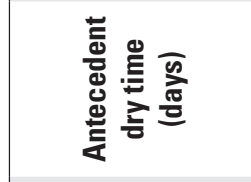 & $\stackrel{\nabla}{i}$ & $\tilde{o}$ & $\stackrel{+}{\oplus}$ & $\vec{i}$ & $\bar{m}$ & $\stackrel{+}{\dot{r}}$ & $\stackrel{n}{f}$ & $\stackrel{+}{\oplus}$ & $\hat{\sigma}$ & $\sqrt[n]{ }$ & c & & & i & 冓 & $\stackrel{m}{\longrightarrow}$ & $\tilde{o}$ & $\ddot{n}$ & $\stackrel{\ominus}{\sim}$ & $\stackrel{\infty}{\dot{n}}$ & $\stackrel{?}{\pi}$ & $\stackrel{m}{\infty}$ & $\stackrel{\nabla}{0}$ & $\stackrel{0}{0}$ & S. \\
\hline 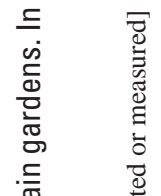 & 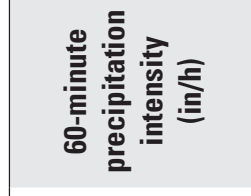 & त̃ & तु & i & $\stackrel{\infty}{\circ}$ & $\stackrel{8}{\circ}$ & ; & సิ & $\stackrel{8}{\circ}$ & $\stackrel{d}{a}$ & $\tilde{c}$ & & 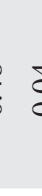 & & 定 & $\begin{array}{l}n \\
\dot{0} \\
\dot{0}\end{array}$ & તે & 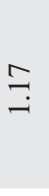 & $\begin{array}{l}\qquad 0 \\
0 \\
0\end{array}$ & $\frac{5}{0}$ & i & : & $\stackrel{8}{\circ}$ & $\stackrel{ \pm}{\stackrel{ \pm}{-}}$ & i & i \\
\hline 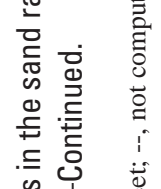 & 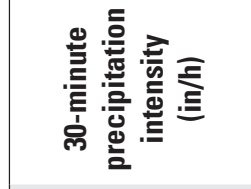 & ֶి & $\stackrel{\text { f }}{0}$ & $\stackrel{\circ}{\circ}$ & $\stackrel{\widetilde{N}}{\text { İ }}$ & $\stackrel{\circ}{\circ}$ & กี่ & mे & $\stackrel{\infty}{\circ}$ & $\stackrel{\alpha}{c}$ & $\mathfrak{c}^{\infty}$ & & 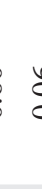 & & 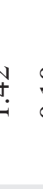 & $\frac{0}{0}$ & $\begin{array}{l}\stackrel{0}{i} \\
\text { in }\end{array}$ & $\stackrel{8}{9}$ & $\stackrel{t}{0}$ & 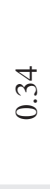 & $\stackrel{\circ}{\circ}$ & ! & $\stackrel{0}{\circ}$ & $\stackrel{\infty}{\rightarrow}$ & : & ֻٕ) \\
\hline 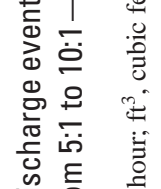 & 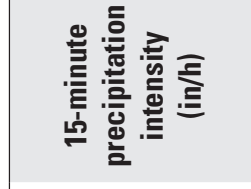 & $\stackrel{\overbrace{}}{0}$ & $\begin{array}{l}\mathbb{d} \\
\stackrel{0}{0}\end{array}$ & $\stackrel{0}{\circ}$ & $\stackrel{+}{\infty}$ & $\stackrel{0}{0}$ & Sু & $\stackrel{0}{0}$ & $\frac{1}{0}$ & 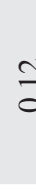 & in & & 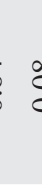 & & 尊 & તิ & $\begin{array}{l}\infty \\
\infty \\
i \\
i\end{array}$ & $\begin{array}{l}\mathbb{d} \\
\text { i }\end{array}$ & $\stackrel{\text { n̊ }}{n}$ & $\stackrel{\infty}{\stackrel{\infty}{0}}$ & $\stackrel{0}{0}$ & $\stackrel{o}{\stackrel{0}{0}}$ & సి & $\begin{array}{l}\stackrel{\infty}{m} \\
\text { m. }\end{array}$ & i & $\stackrel{\mathbb{Z}}{\stackrel{\mathbb{S}}{0}}$ \\
\hline 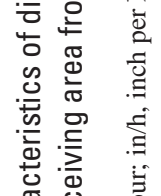 & 衮 & $\stackrel{0}{+}$ & $\bar{n}$ & $\stackrel{8}{\circ}$ & $\underset{i}{i}$ & $\stackrel{\infty}{0}$ & 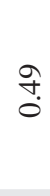 & & กี & ca & f & & 7 & & $\underline{n}$ & $\begin{array}{l}\text { oे } \\
\dot{0}\end{array}$ & $\underset{i}{\stackrel{+}{+}}$ & $\stackrel{n}{?}$ & $\underset{\text { S̃ }}{\text { i }}$ & $\stackrel{m}{0}$ & $\stackrel{8}{\circ}$ & $\overrightarrow{0}$ & $\stackrel{m}{0}$ & $\stackrel{\text { ô }}{-}$ & $\begin{array}{l}n \\
0 \\
0\end{array}$ & $\vec{ָ}$ \\
\hline 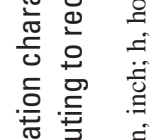 & 竧 & $\vec{r}$ & $\stackrel{\bullet}{\circ}$ & $\dddot{n}$ & $\stackrel{\circ}{\vec{\lambda}}$ & $\widetilde{N}$ & $\stackrel{\sim}{\infty}$ & & $\tilde{n}$ & & v & & 4 & & t. & $\begin{array}{l}\dot{0} \\
\dot{m}\end{array}$ & $\stackrel{\infty}{\stackrel{\infty}{\varrho}}$ & $\widehat{\grave{j}}$ & $\hat{\varrho}$ & $\stackrel{\infty}{\stackrel{0}{\circ}}$ & $\stackrel{\infty}{i}$ & $\stackrel{-}{-}$ & $\stackrel{n}{=}$ & $\hat{\sigma}$ & $\stackrel{n}{+}$ & $\stackrel{i}{i}$ \\
\hline 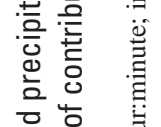 & 豈名豆 & $\stackrel{m}{\ddot{\dot{J}}}$ & $\underset{\stackrel{\circ}{\circ}}{\stackrel{8}{0}}$ & 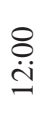 & 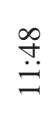 & 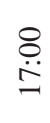 & 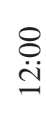 & & $\underset{\stackrel{\leftrightarrow}{\mathrm{I}}}{ }$ & $\underset{\dot{d}}{\mathscr{d}}$ & $\stackrel{\varepsilon}{\dot{c}}$ & & 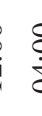 & & b. & $\begin{array}{l}8 \\
\dot{g}\end{array}$ & 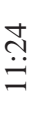 & $\begin{array}{l}\stackrel{8}{\dot{\theta}} \\
\text { }\end{array}$ & 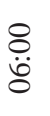 & $\begin{array}{l}\stackrel{8}{\dot{\theta}} \\
\dot{\phi}\end{array}$ & $\begin{array}{l}\stackrel{8}{\circ} \\
\dot{8}\end{array}$ & هِ & $\begin{array}{l}\stackrel{\leftrightarrow}{0} \\
\stackrel{0}{0}\end{array}$ & 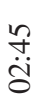 & 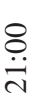 & $\begin{array}{l}8 \\
\stackrel{\leftrightarrow}{\oplus}\end{array}$ \\
\hline 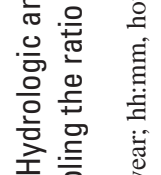 & 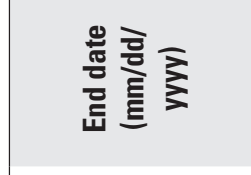 & 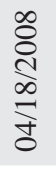 & 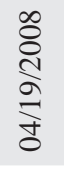 & 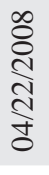 & 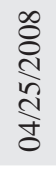 & 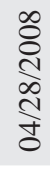 & 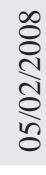 & 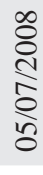 & 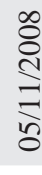 & & $\overbrace{0}^{\infty}$ & & 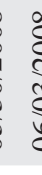 & & 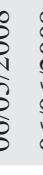 & 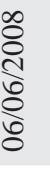 & 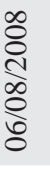 & 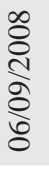 & 离 & 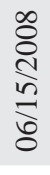 & 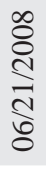 & 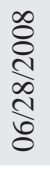 & 交 & $\begin{array}{l}\infty \\
\stackrel{0}{0} \\
\substack{1 \\
0 \\
\stackrel{5}{0}}\end{array}$ & 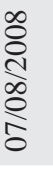 & 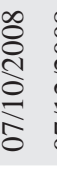 \\
\hline 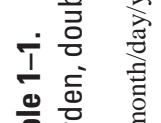 & 悫名焉 & 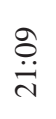 & $\begin{array}{l}\stackrel{\overbrace{}}{\ddot{n}} \\
\stackrel{\ddot{n}}{2}\end{array}$ & $\stackrel{\bar{m}}{\varrho}$ & $\begin{array}{l}\stackrel{o}{+} \\
\dot{\Xi}\end{array}$ & $\begin{array}{l}\stackrel{0}{+} \\
\dot{\Xi}\end{array}$ & $\stackrel{\infty}{\ddot{\sigma}}$ & & 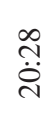 & 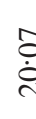 & $\stackrel{8}{\dot{0}}$ & & & & 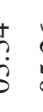 & 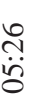 & $\begin{array}{l}\stackrel{m}{\ddot{n}} \\
\ddot{n}\end{array}$ & 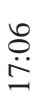 & $\stackrel{n}{\ddot{0}}$ & $\overline{\ddot{n}}$ & $\overline{\ddot{\theta}}$ & 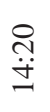 & तે & $\begin{array}{l}\text { ô. } \\
\stackrel{\text { }}{2}\end{array}$ & ֶֶ? & \\
\hline 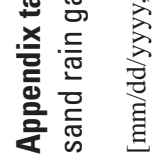 & 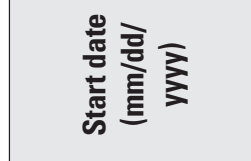 & 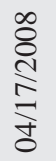 & 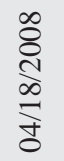 & 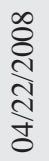 & 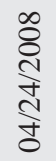 & 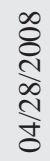 & 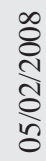 & & 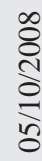 & 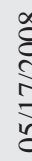 & 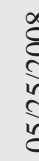 & & ई & & $\frac{5}{6}$ & 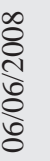 & 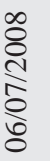 & 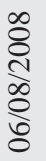 & 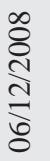 & 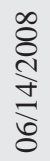 & 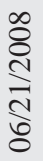 & 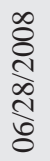 & & 离 & 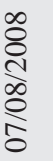 & ֻั) \\
\hline
\end{tabular}




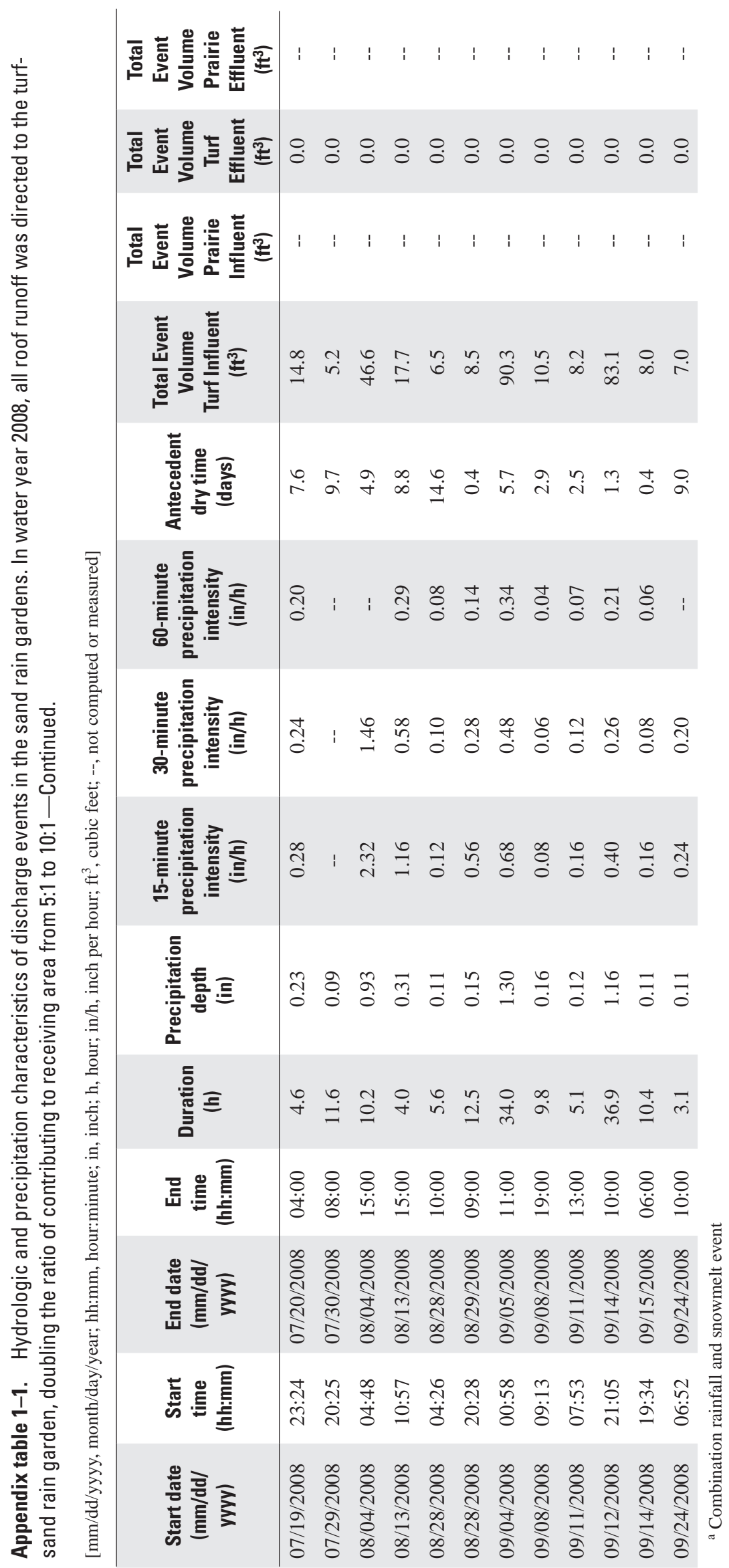




\begin{tabular}{|c|c|c|c|c|c|c|c|c|c|c|c|c|c|c|c|c|c|c|c|c|c|c|c|c|c|c|c|c|}
\hline : & & 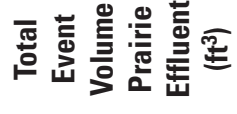 & 0 & 0 & 0 & 0 & 0 & 0 & 0 & 0 & 0 & 0 & 0 & 0 & 0 & 0 & 0 & 0 & 0 & 0 & 0 & 0 & 0 & 0 & 0 & 0 & 0 & 0 \\
\hline $\begin{array}{l}\stackrel{0}{ \pm} \\
\stackrel{0}{+} \\
\stackrel{0}{0}\end{array}$ & & 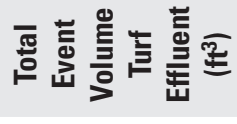 & 0 & 0 & 0 & 0 & 0 & 0 & 0 & กี & 0 & 0 & 0 & 0 & 0 & 0 & 0 & 0 & 0 & 0 & 0 & 0 & 0 & 0 & 0 & 0 & 0 & $\cong$ \\
\hline 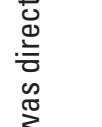 & & 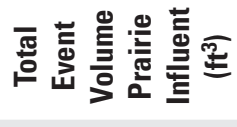 & $\infty$ & \$ & in & $\stackrel{0}{0}$ & $=$ & I & $\underset{+}{\sim}$ & m & $\Xi$ & $\bar{\sim}$ & 7 & $\bar{F}$ & مू & $\stackrel{\infty}{\infty}$ & in & ปี & + & $\cong$ & in & $\stackrel{\infty}{m}$ & $\stackrel{m}{\forall}$ & $\stackrel{\infty}{+}$ & $m$ & $\omega_{\infty}$ & రु & $\bar{n}$ \\
\hline $\begin{array}{l}\frac{1}{0} \\
\stackrel{2}{2} \\
\frac{2}{0} \\
0\end{array}$ & & 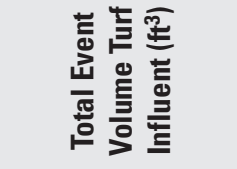 & $\stackrel{\infty}{\mathbb{N}}$ & in & ๖ & $\begin{array}{l}\circ \\
n\end{array}$ & $\stackrel{0}{0}$ & ก & 巳 & $\stackrel{\infty}{+}$ & $\stackrel{n}{n}$ & ్ి & & in & $\frac{N}{\infty}$ & 昌 & ర & 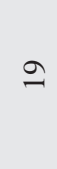 & $\bar{\infty}$ & \pm & กี & r & $\stackrel{m}{\forall}$ & $\stackrel{n}{f}$ & లి & 으 & $\widehat{6}$ & 稌 \\
\hline 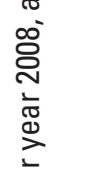 & & 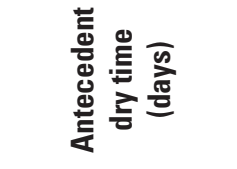 & i & $\stackrel{0}{r}$ & $\Xi$ & กิ & $\hat{o}$ & 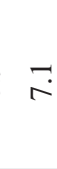 & $: \stackrel{+}{0}$ & $\dot{i}$ & $\vec{\infty}$ & i. & in & $\begin{array}{l}\text { y } \\
\text { in }\end{array}$ & $\dot{0}$ & $\vec{i}$ & $\stackrel{\text { ก̣ }}{2}$ & $\grave{0}$ & $\tilde{n}$ & $\tilde{o}$ & $\stackrel{b}{m}$ & $\stackrel{m}{\ddot{n}}$ & $\stackrel{0}{-}$ & $\stackrel{\infty}{i}$ & 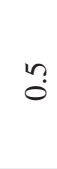 & $\stackrel{m}{m}$ & $\vec{m}$ & ?̊ \\
\hline 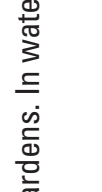 & 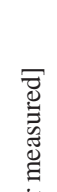 & 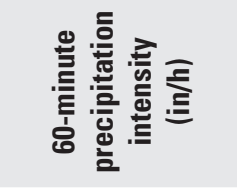 & 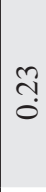 & $\stackrel{+}{0}$ & $\frac{m}{0}$ & I & ?2 & $\frac{0}{0}$ & $=$ & $\stackrel{\infty}{1}$ & $\stackrel{+}{0}$ & i & $\stackrel{8}{8}$ & : & $\stackrel{t}{\stackrel{0}{0}}$ & $\exists$ & กี & i & $\underset{ก}{\tilde{0}}$ & i & $\stackrel{\infty}{0}$ & $\frac{5}{0}$ & $\overline{0}$ & $\frac{0}{0}$ & ọ & $\stackrel{\infty}{\infty}$ & $\stackrel{f}{ \pm}$ & ๙̊ \\
\hline 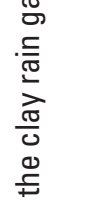 & 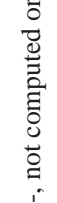 & 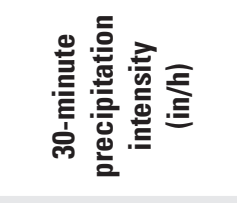 & $\stackrel{\infty}{\stackrel{0}{0}}$ & : & $\stackrel{\infty}{0}$ & i & $\stackrel{8}{8}$ & $\stackrel{ \pm}{0}$ & กิ & n̊ & $\stackrel{8}{8}$ & $\stackrel{\infty}{\stackrel{1}{0}}$ & & $\frac{0}{0}$ & $\stackrel{\infty}{0}$ & $\stackrel{0}{\circ}$ & $\stackrel{9}{0}$ & i & $\stackrel{\sharp}{\sim}$ & i & $\stackrel{\infty}{0}$ & ก̊ & กี & กี & $\stackrel{\infty}{0}$ & $\stackrel{0}{=}$ & ? & $\stackrel{+}{\text { m }}$ \\
\hline 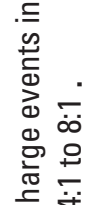 & 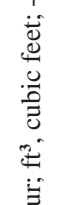 & 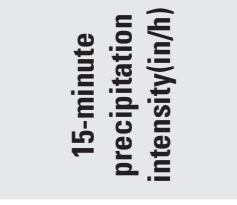 & กิ & $\stackrel{\infty}{\infty}$ & $\stackrel{\infty}{\stackrel{1}{0}}$ & i & $\stackrel{\infty}{0}$ & గి & ?ִ & : & $\stackrel{\infty}{0}$ & ?ึ? & & $\frac{1}{0}$ & 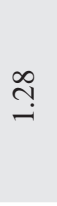 & กิ & ڤ̊ & đọ & กี & i & $\frac{0}{0}$ & $\stackrel{\mathbb{Z}}{0}$ & กี่ & $\stackrel{8}{8}$ & $\frac{N}{0}$ & 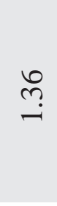 & 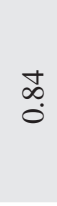 & $\stackrel{\infty}{\infty}$ \\
\hline 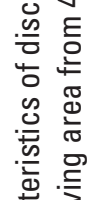 & 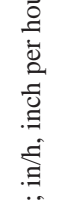 & 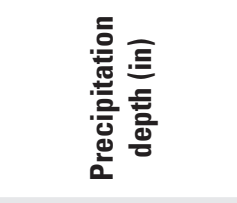 & $\stackrel{\text { g }}{-}$ & $\frac{\bar{\sigma}}{0}$ & గొ & $\begin{array}{l}\text { 릴 } \\
\text { है } \\
\text { oี } \\
\text { क }\end{array}$ & $=$ & $\stackrel{ \pm}{0}$ & ঙ̊. & 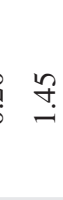 & 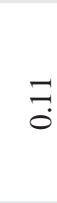 & $\frac{0}{0}$ & & $\frac{\infty}{0}$ & $\bar{n}$ & $\stackrel{m}{0}$ & $\begin{array}{l}\sigma \\
0 \\
0\end{array}$ & $\frac{\infty}{0}$ & $\stackrel{\infty}{\stackrel{\infty}{0}}$ & $\overline{0}$ & $\stackrel{\infty}{+}$ & ?ొ & $\hat{n}$ & $\stackrel{J}{0}$ & గి & $\stackrel{n}{\mathfrak{0}}$ & กี & $\stackrel{n}{a}$ \\
\hline 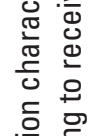 & 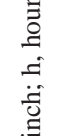 & 흘 흘 & 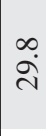 & ָָ & $\stackrel{\infty}{\stackrel{0}{0}}$ & †ิ & $\stackrel{0}{0}$ & $\underset{\dot{r}}{b}$ & $\stackrel{?}{\pi}$ & 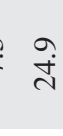 & ชู & 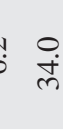 & $\stackrel{0}{0}$ & ¿ें & $\vec{\sim}$ & $\stackrel{\Upsilon}{r}$ & $\stackrel{\vartheta}{+}$ & 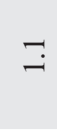 & $\underset{\infty}{0}$ & $\stackrel{\infty}{0}$ & $\stackrel{\infty}{\infty}$ & ดิ & $\stackrel{\infty}{\stackrel{\infty}{\rightleftharpoons}}$ & ○. & $\vec{r}$ & $\stackrel{0}{\circ}$ & $\vec{i}$ & ñ \\
\hline 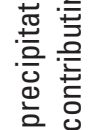 & 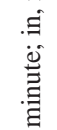 & 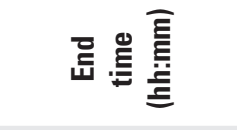 & 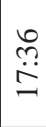 & 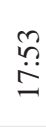 & $\stackrel{\widetilde{n}}{\tilde{\sigma}}$ & $\stackrel{\stackrel{\Xi}{\Xi}}{\circ}$ & $\stackrel{\stackrel{n}{ }}{\stackrel{\sim}{\sim}}$ & $\begin{array}{l}\forall \\
\dot{\Xi}\end{array}$ & 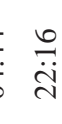 & $\begin{array}{l}\overrightarrow{0} \\
\stackrel{\infty}{0}\end{array}$ & $\overline{\ddot{\delta}}$ & 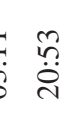 & $\stackrel{n}{n}$ & $\frac{\hat{n}}{\tilde{n}}$ & $\stackrel{\hat{m}}{\ddot{g}}$ & $\begin{array}{l}\infty \\
\dddot{\infty} \\
\infty \\
\infty\end{array}$ & 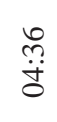 & 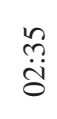 & $\begin{array}{l}\stackrel{+}{\ddot{~}} \\
\text { ते }\end{array}$ & $\begin{array}{l}\stackrel{?}{0} \\
\ddot{\delta}\end{array}$ & $\begin{array}{l}\stackrel{\text { ஸे }}{\underline{\sim}}\end{array}$ & $\frac{0}{\ddot{\delta}}$ & $\stackrel{\theta}{\ddot{\theta}}$ & 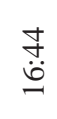 & 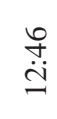 & $\begin{array}{l}o ̛ \\
\ddot{\theta}\end{array}$ & $\stackrel{m}{\dddot{g}}$ & $\begin{array}{c}\stackrel{\sim}{\dddot{0}} \\
\dot{\otimes}\end{array}$ \\
\hline 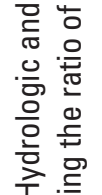 & 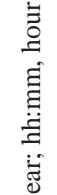 & 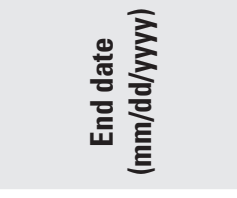 & 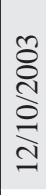 & 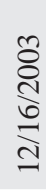 & 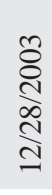 & 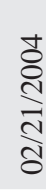 & $\begin{array}{l}\text { ปे } \\
\text { ปे } \\
\text { ปे } \\
\text { ปे }\end{array}$ & $\frac{\substack{1 \\
8}}{8}$ & $\frac{1}{8}$ & 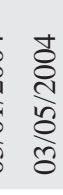 & 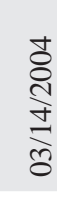 & $\frac{0}{\infty}$ & 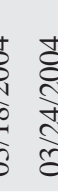 & 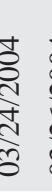 & 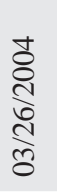 & 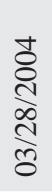 & 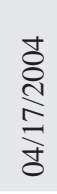 & 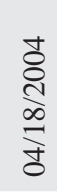 & 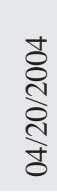 & 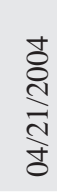 & 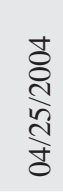 & 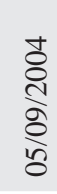 & 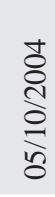 & $\frac{\substack{0 \\
\frac{d}{n}}}{\frac{n}{n}}$ & 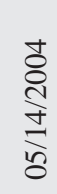 & $\frac{\substack{1 \\
\frac{1}{1}}}{\frac{\infty}{\pi}}$ & 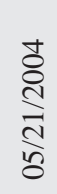 & 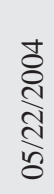 \\
\hline 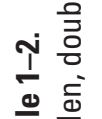 & 產 & 䔍导豆 & $\begin{array}{l}\stackrel{?}{?} \\
\stackrel{=}{=}\end{array}$ & $\begin{array}{l}\stackrel{+}{+} \\
\stackrel{\infty}{\infty}\end{array}$ & $\begin{array}{l}\stackrel{n}{\pi} \\
\dot{\pi}\end{array}$ & 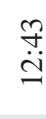 & $\begin{array}{l}\widehat{N} \\
\ddot{n}\end{array}$ & $\begin{array}{l}o \\
\dot{ர}\end{array}$ & $\stackrel{n}{\mathscr{\pm}}$ & 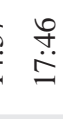 & $\frac{8}{\stackrel{8}{\sim}}$ & 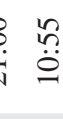 & $\frac{m}{\dot{a}}$ & $\frac{m}{\ddot{\sigma}}$ & 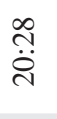 & $\stackrel{\infty}{\stackrel{+}{=}}$ & 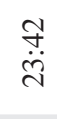 & $\frac{\widetilde{N}}{\stackrel{\oplus}{0}}$ & 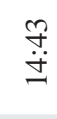 & 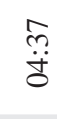 & $\begin{array}{l}8 \\
\dot{0}\end{array}$ & $\frac{\Omega}{\ddot{\delta}}$ & 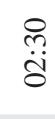 & $\stackrel{0}{+}$ & $\begin{array}{l}\stackrel{+}{+} \\
\ddot{0}\end{array}$ & $\begin{array}{l}\text { ț } \\
\dot{\hat{\theta}}\end{array}$ & 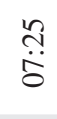 & $\stackrel{0}{\ddot{6}}$ \\
\hline 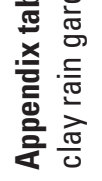 & 齐 & 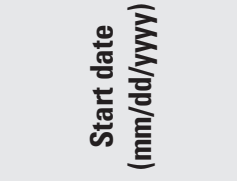 & 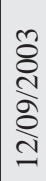 & 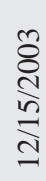 & 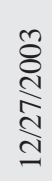 & 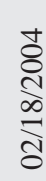 & $\begin{array}{l}\text { ป } \\
\text { ป } \\
\text { ป } \\
\text { ป̀ }\end{array}$ & 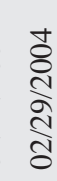 & 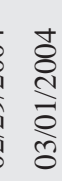 & 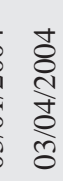 & 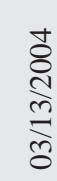 & $\frac{8}{3}$ & 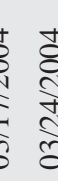 & $\begin{array}{l}\frac{d}{8} \\
\frac{1}{4} \\
\frac{1}{6} \\
6\end{array}$ & $\begin{array}{l}\frac{1}{8} \\
\frac{1}{2} \\
\frac{\pi}{2}\end{array}$ & 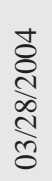 & 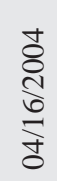 & 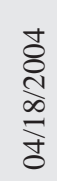 & 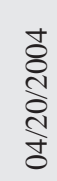 & 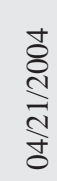 & 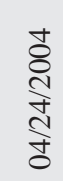 & 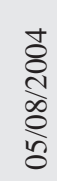 & ڤั) & 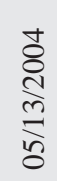 & $\frac{\text { d }}{8}$ & $\frac{\substack{0 \\
\frac{1}{5}}}{\frac{\pi}{5}}$ & 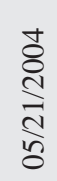 & 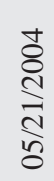 \\
\hline
\end{tabular}




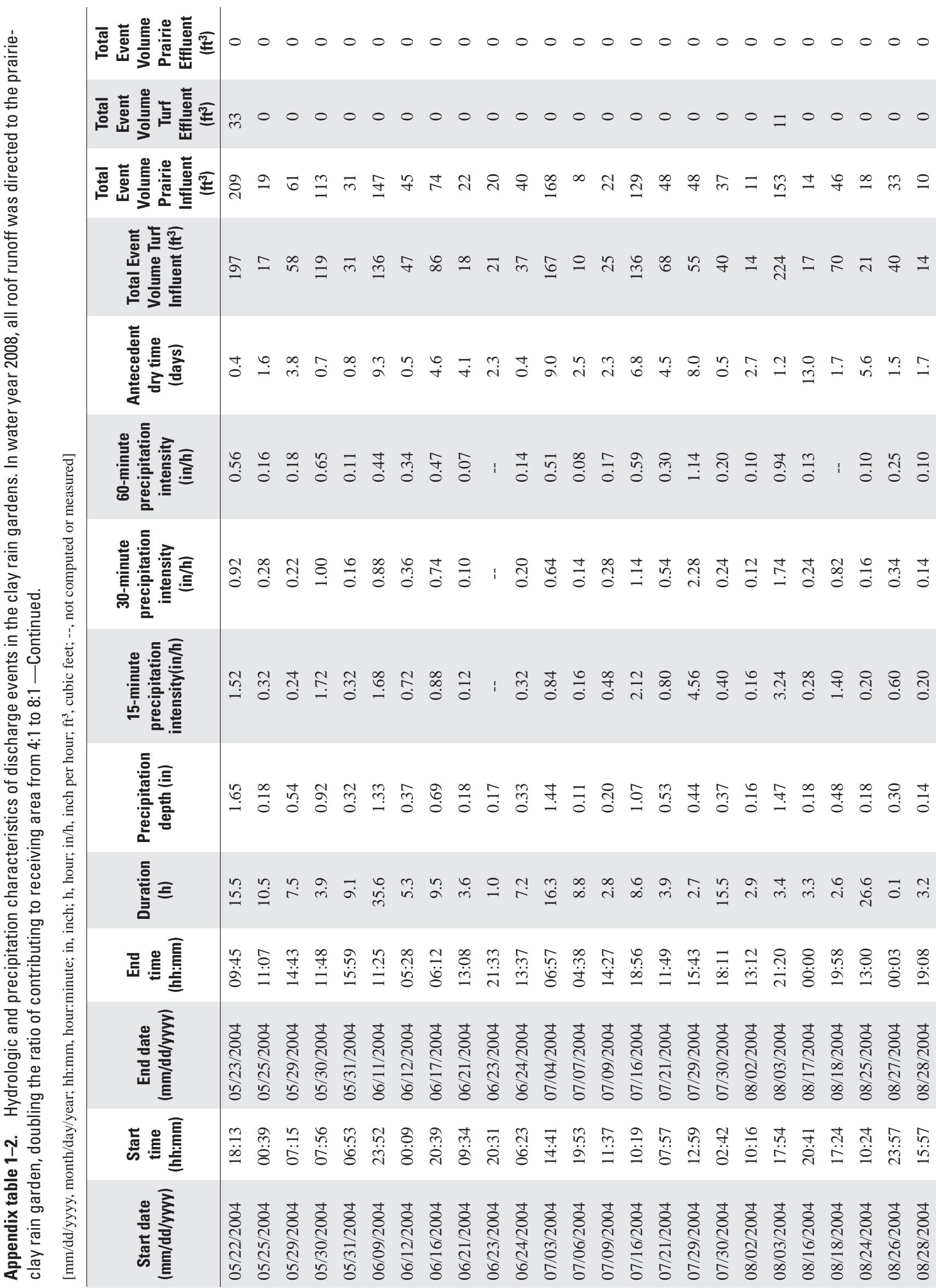




\begin{tabular}{|c|c|c|c|c|c|c|c|c|c|c|c|c|c|c|c|c|c|c|c|c|c|c|c|c|c|c|c|c|}
\hline : & & 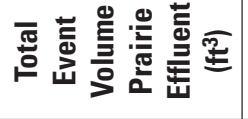 & 0 & 0 & 0 & 0 & 0 & 0 & 0 & 0 & 0 & 0 & 0 & 0 & 0 & 0 & 0 & 0 & 0 & 0 & & 0 & 0 & 0 & 0 & 0 & 0 & 0 \\
\hline $\begin{array}{l}\stackrel{\oplus}{\leftrightarrows} \\
\stackrel{0}{\circ} \\
\stackrel{0}{0}\end{array}$ & & 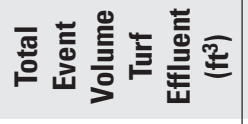 & 0 & 0 & 0 & 0 & 0 & 0 & 0 & 0 & 0 & 0 & 0 & 0 & 0 & 0 & 0 & 0 & 0 & $a$ & & 0 & 0 & 0 & 0 & 구 & 0 & 0 \\
\hline 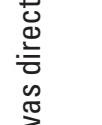 & & 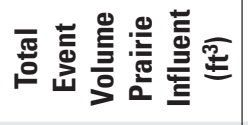 & శ్ర & $\underline{-}$ & 6 & $\infty$ & $\bar{\infty}$ & $\stackrel{\infty}{\sim}$ & $\hat{n}$ & $\stackrel{\infty}{-}$ & $\widehat{\curvearrowright}$ & రु & $\tilde{N}$ & $\infty$ & P & $\stackrel{\infty}{+}$ & $\stackrel{+}{\sim}$ & $\stackrel{n}{r}$ & $\stackrel{\infty}{-}$ & $\Omega$ & & $\tilde{c}$ & $=$ & f & $\vec{m}$ & $\cong$ & $\stackrel{\rho}{=}$ & $\stackrel{m}{\forall}$ \\
\hline 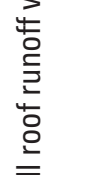 & & 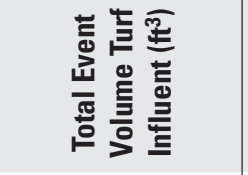 & $\stackrel{P}{1}$ & $\stackrel{n}{2}$ & $\stackrel{m}{r}$ & ๙ & n & ते & 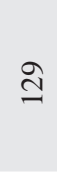 & $\stackrel{\infty}{-}$ & $\vec{m}$ & $\approx$ & $\overparen{1}$ & $a$ & $\overrightarrow{7}$ & $\approx$ & $n$ & $\stackrel{P}{2}$ & సి & $\overline{\text { స }}$ & & $\vec{N}$ & $=$ & f & nి & \& & $\stackrel{2}{\simeq}$ & lo \\
\hline 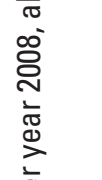 & & 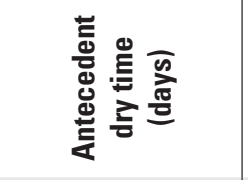 & $\stackrel{+}{\dot{r}}$ & $\stackrel{\infty}{+}$ & $\stackrel{0}{\circ}$ & $\stackrel{\vartheta}{\Omega}$ & $\stackrel{0}{0}$ & $\stackrel{+}{0}$ & $m$ & $\stackrel{m}{m}$ & $\stackrel{\infty}{i}$ & $\stackrel{\circ}{i}$ & $\stackrel{\infty}{-}$ & $\stackrel{0}{\Xi}$ & $\hat{\sim}$ & $\tilde{6}$ & $\stackrel{m}{\infty}$ & ? & $\stackrel{\infty}{i}$ & กై & & 9 & m? & $\begin{array}{l}\infty \\
\dot{n}\end{array}$ & ?̊ & $\begin{array}{l}\stackrel{\sim}{N} \\
\ddot{n}\end{array}$ & ț. & $\stackrel{\vartheta}{\forall}$ \\
\hline 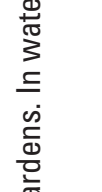 & 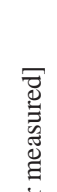 & 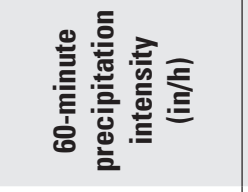 & $\underset{0}{\nabla}$ & $\stackrel{8}{\circ}$ & సి & $\stackrel{n}{\circ}$ & ơ & $\frac{1}{0}$ & సิ & $\stackrel{n}{2}$ & กิ & $\stackrel{\circ}{\circ}$ & $\overline{0}$ & $\stackrel{2}{2}$ & $\stackrel{\circ}{\circ}$ & $\stackrel{8}{\circ}$ & $\frac{9}{0}$ & $\stackrel{ \pm}{0}$ & $\stackrel{2}{0}$ & : & & ô. & $\stackrel{\infty}{\circ}$ & $\exists$ & $\stackrel{m}{0}$ & กี & $\begin{array}{l}0 \\
0 \\
0\end{array}$ & $\frac{\infty}{0}$ \\
\hline 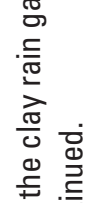 & 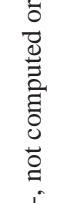 & 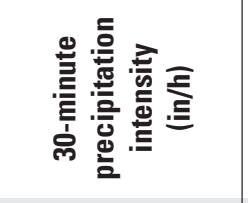 & $\stackrel{+}{0}$ & $\frac{\infty}{0}$ & $\stackrel{\infty}{\stackrel{\infty}{0}}$ & $\stackrel{0}{\circ}$ & 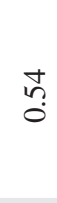 & $\stackrel{0}{\circ}$ & กี & $\stackrel{8}{\circ}$ & mे & $\stackrel{\infty}{\circ}$ & $\frac{1}{0}$ & ¿̊ & ठ̣ & $\frac{1}{0}$ & గి & $\frac{\infty}{0}$ & $\stackrel{8}{\circ}$ & : & & ?ִ & $\stackrel{\circ}{\circ}$ & $\frac{ \pm}{0}$ & กิ & $\begin{array}{l}\mathbb{J} \\
0\end{array}$ & $\stackrel{\circ}{\circ}$ & กొ \\
\hline 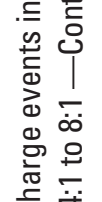 & 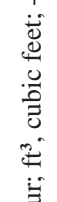 & 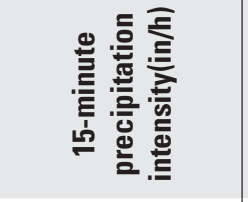 & $\stackrel{I}{\leftrightarrows}$ & గొ & $\stackrel{9}{+}$ & $\stackrel{\infty}{\circ}$ & $\begin{array}{l}\infty \\
0 \\
0\end{array}$ & กิ & $\stackrel{\text { q }}{0}$ & $\stackrel{\infty}{0}$ & กี & $\frac{1}{0}$ & $\frac{0}{0}$ & $\stackrel{\infty}{0}$ & $\stackrel{\infty}{0}$ & $\frac{0}{0}$ & $\stackrel{+}{0}$ & $\stackrel{+}{\sim}$ & $\stackrel{\infty}{0}$ & $\begin{array}{l}0 \\
0 \\
0\end{array}$ & & $\frac{1}{0}$ & $\stackrel{1}{\circ}$ & $\frac{0}{0}$ & กี & సి & $\stackrel{\simeq}{\leftrightarrows}$ & กี \\
\hline 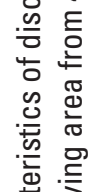 & 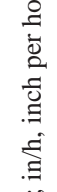 & 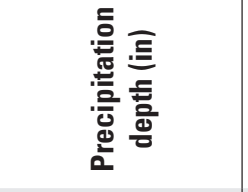 & ڤ̊ & $\stackrel{ \pm}{0}$ & $\begin{array}{l}\widetilde{\sigma} \\
0\end{array}$ & $\overrightarrow{0}$ & $\stackrel{\infty}{\infty}$ & 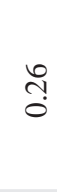 & 웅 & ণิ & ஸి & ח̊ & $\vec{ָ}$ & $\stackrel{ \pm}{0}$ & $\hat{n}$ & $\stackrel{n}{\circ}$ & ஜُ & 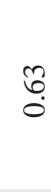 & $\stackrel{n}{0}$ & $\begin{array}{l}\stackrel{\pi}{\infty} \\
\infty \\
0\end{array}$ & & تَّ & $\stackrel{\tilde{\sigma}}{n}$ & $\stackrel{\frac{\sigma}{2}}{\stackrel{2}{0}}$ & $\stackrel{\stackrel{5}{n}}{\stackrel{0}{0}}$ & $\stackrel{\widetilde{J}}{\stackrel{0}{0}}$ & $\stackrel{\sigma}{0}$ & $\stackrel{\vartheta}{\dot{0}}$ \\
\hline 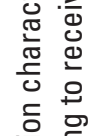 & 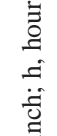 & 흔 & $\stackrel{\infty}{i}$ & 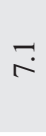 & $\hat{a}$ & 9 & $\vec{n}$ & $\vec{a}$ & $\stackrel{\circ}{\dot{I}}$ & $\begin{array}{l}\infty \\
\dot{\Xi}\end{array}$ & $\tilde{a}$ & $\stackrel{\widetilde{N}}{\stackrel{\mathrm{N}}{ }}$ & $\stackrel{m}{\infty}$ & $\stackrel{\widehat{\jmath}}{\mathrm{J}}$ & ث̊. & $\stackrel{\vartheta}{\dot{J}}$ & $\stackrel{m}{n}$ & $\stackrel{b}{i}$ & ?ึ่ & \ั) & $\begin{array}{ll}n \\
1 \\
3\end{array}$ & ?ִ & $\stackrel{\leftrightarrow}{\text { ¿ }}$ & $\begin{array}{l}\circ \\
\stackrel{\sim}{0}\end{array}$ & $\ddot{\infty}$ & $\overrightarrow{\tilde{N}}$ & $\overrightarrow{0}$ & $\begin{array}{l}0 \\
\infty \\
\infty\end{array}$ \\
\hline 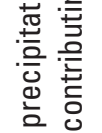 & 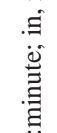 & 豆导豆 & $\frac{n}{\grave{1}}$ & $\stackrel{8}{8}$ & $\begin{array}{l}\bar{\sigma} \\
\dot{\sigma}\end{array}$ & $\begin{array}{l}\text { ¿̦ } \\
\dot{\vec{d}}\end{array}$ & $\begin{array}{l}\overline{0} \\
\ddot{n}\end{array}$ & $\begin{array}{l}8 \\
\dot{0}\end{array}$ & 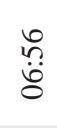 & $\begin{array}{l}8 \\
\dot{\leftrightarrow}\end{array}$ & $\underset{\dot{o}}{\tilde{o}}$ & ஜ̊ & 可 & $\begin{array}{l}\tilde{v} \\
\ddot{v}\end{array}$ & 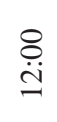 & 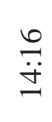 & $\stackrel{n}{0}$ & $\stackrel{n}{\tilde{8}}$ & $\frac{\widetilde{N}}{\ddot{\sim}}$ & 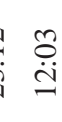 & 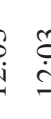 & 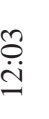 & 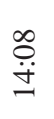 & $\begin{array}{l}\hat{0} \\
\dot{\theta}\end{array}$ & $\begin{array}{l}\hat{o} \\
\dot{8}\end{array}$ & $\begin{array}{l}n \\
\dot{0}\end{array}$ & $\frac{\Delta}{\ddot{\theta}}$ & 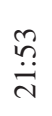 \\
\hline 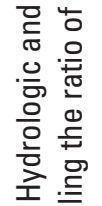 & 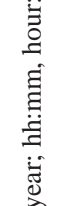 & 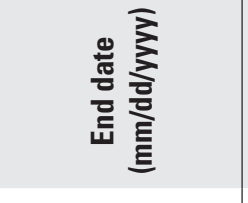 & $\begin{array}{l}\text { d } \\
\text { ì } \\
\text { o } \\
\text { o }\end{array}$ & $\begin{array}{l}\text { t } \\
\text { o } \\
\text { d } \\
\text { o } \\
8\end{array}$ & $\frac{\substack{8 \\
\frac{1}{1} \\
\frac{5}{2}}}{8}$ & 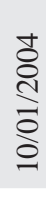 & $\begin{array}{l}\text { d } \\
\stackrel{1}{1} \\
\infty \\
ᄋ \\
0\end{array}$ & 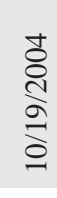 & 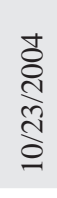 & 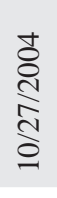 & 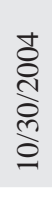 & 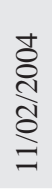 & 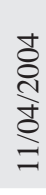 & 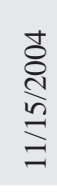 & 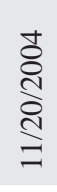 & 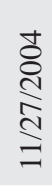 & 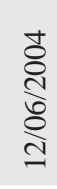 & ¿্ঠ & $\begin{array}{l}\text { ¿ } \\
\text { ป̀ } \\
\text { ป }\end{array}$ & $\frac{n}{8}$ & & 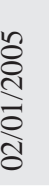 & 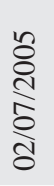 & 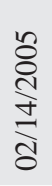 & 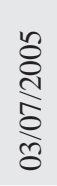 & 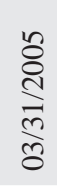 & 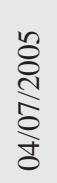 & 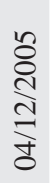 \\
\hline ํㅡㅁ & 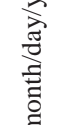 & 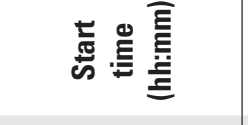 & $\frac{\infty}{\ddot{\dot{\sigma}}}$ & $\begin{array}{l}\stackrel{+}{n} \\
\text { ஸे }\end{array}$ & $\ddot{\tilde{g}}$ & 匐 & 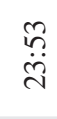 & $\begin{array}{l}\bar{n} \\
8\end{array}$ & $\stackrel{n}{n}$ & $\overline{\ddot{\ddot{g}}}$ & 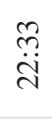 & $\begin{array}{l}\stackrel{\infty}{+} \\
\stackrel{\infty}{\infty}\end{array}$ & 辛 & $\begin{array}{l}\mathscr{0} \\
\stackrel{0}{0}\end{array}$ & 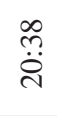 & $\begin{array}{l}\stackrel{\vec{v}}{\ddot{v}} \\
\dot{\sim}\end{array}$ & $\frac{\stackrel{N}{+}}{\stackrel{\sim}{~}}$ & 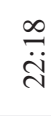 & $\begin{array}{l}n \\
\stackrel{n}{2}\end{array}$ & 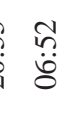 & & ֶֻ. & $\begin{array}{l}\stackrel{\rho}{0} \\
\dot{\infty}\end{array}$ & 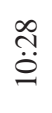 & $\begin{array}{l}\stackrel{\vartheta}{+} \\
\dot{8}\end{array}$ & $\begin{array}{l}\overline{\dot{\Xi}} \\
\dot{ \pm}\end{array}$ & $\begin{array}{l}\text { oे } \\
\text { فे }\end{array}$ & $\frac{\partial}{\ddot{\sigma}}$ \\
\hline 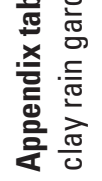 & 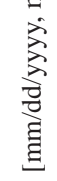 & 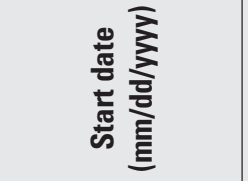 & 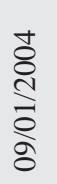 & 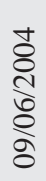 & $\begin{array}{l}\frac{1}{8} \\
\frac{1}{2} \\
\frac{8}{8}\end{array}$ & 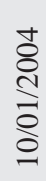 & 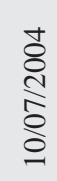 & 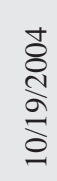 & 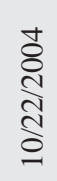 & 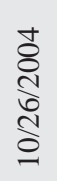 & 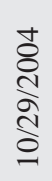 & 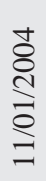 & 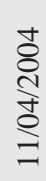 & 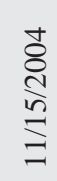 & 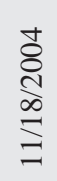 & $\begin{array}{l}\text { d } \\
\text { d } \\
\text { d } \\
\text { J } \\
=\end{array}$ & 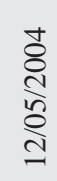 & $\begin{array}{l}\text { d } \\
\stackrel{d}{\delta} \\
\stackrel{d}{ป}\end{array}$ & 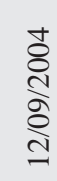 & $\frac{n}{8}$ & & 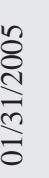 & 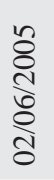 & 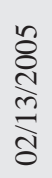 & 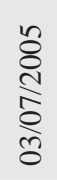 & 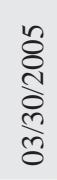 & 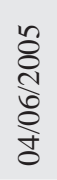 & 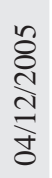 \\
\hline
\end{tabular}




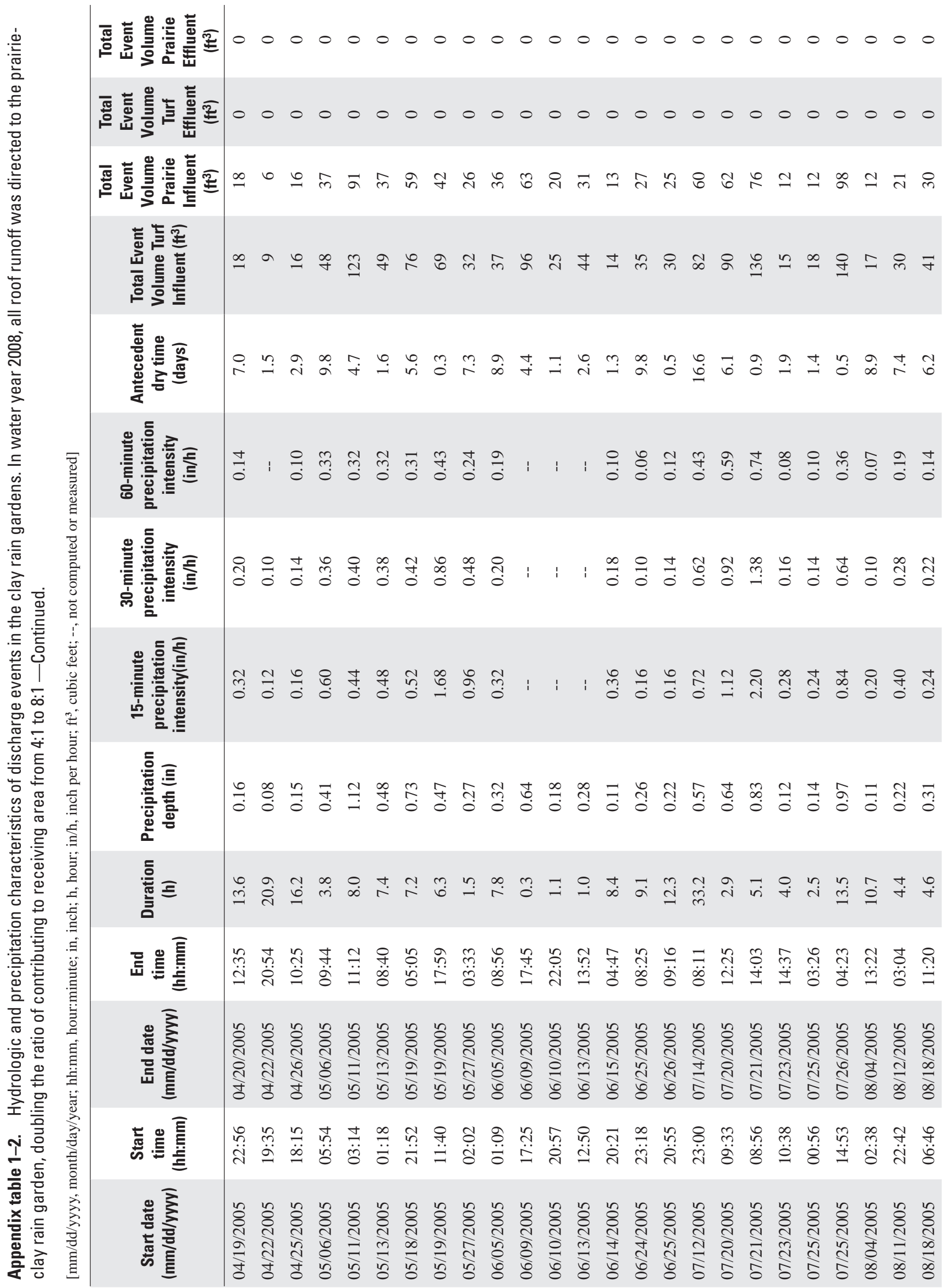




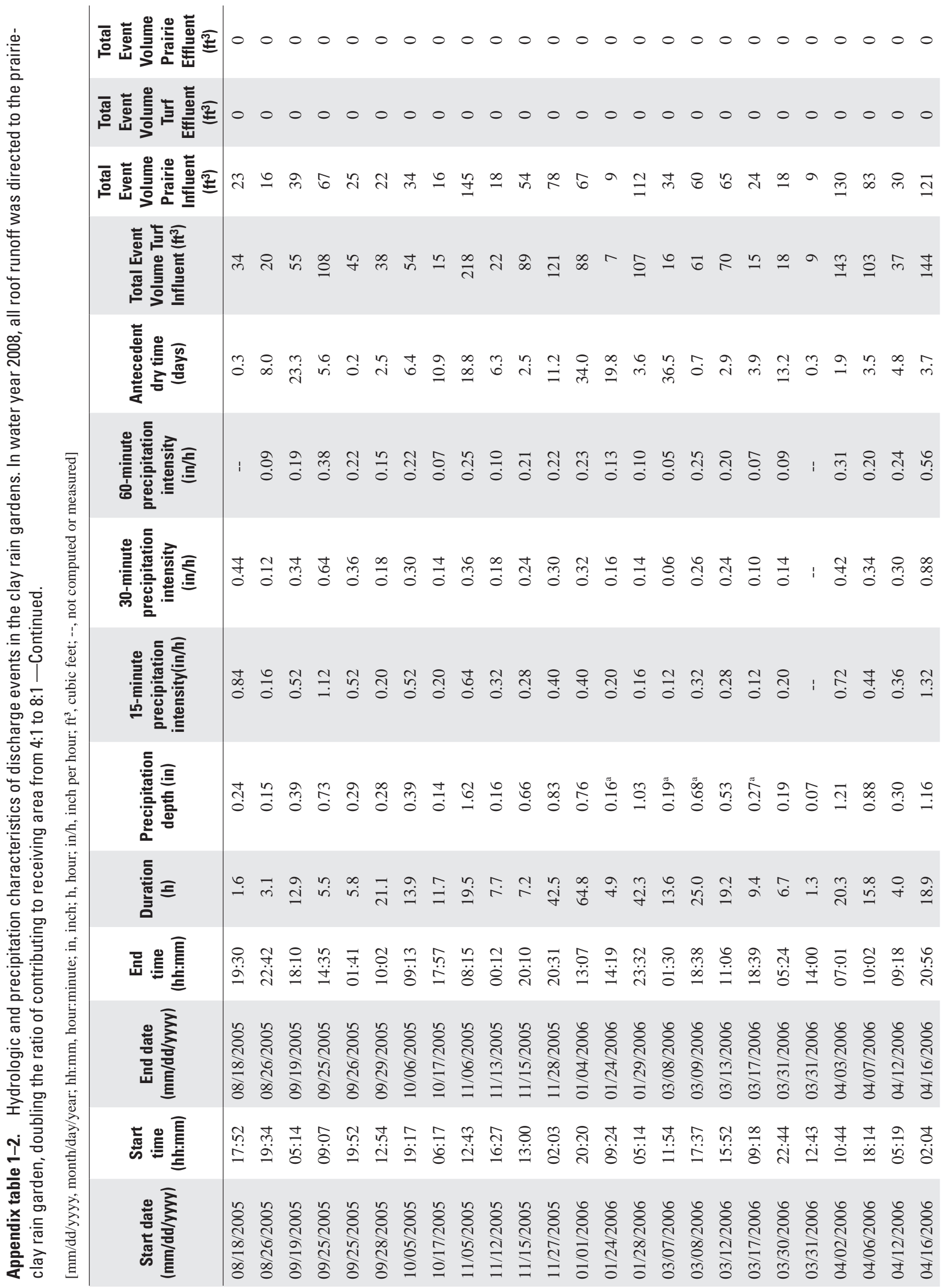




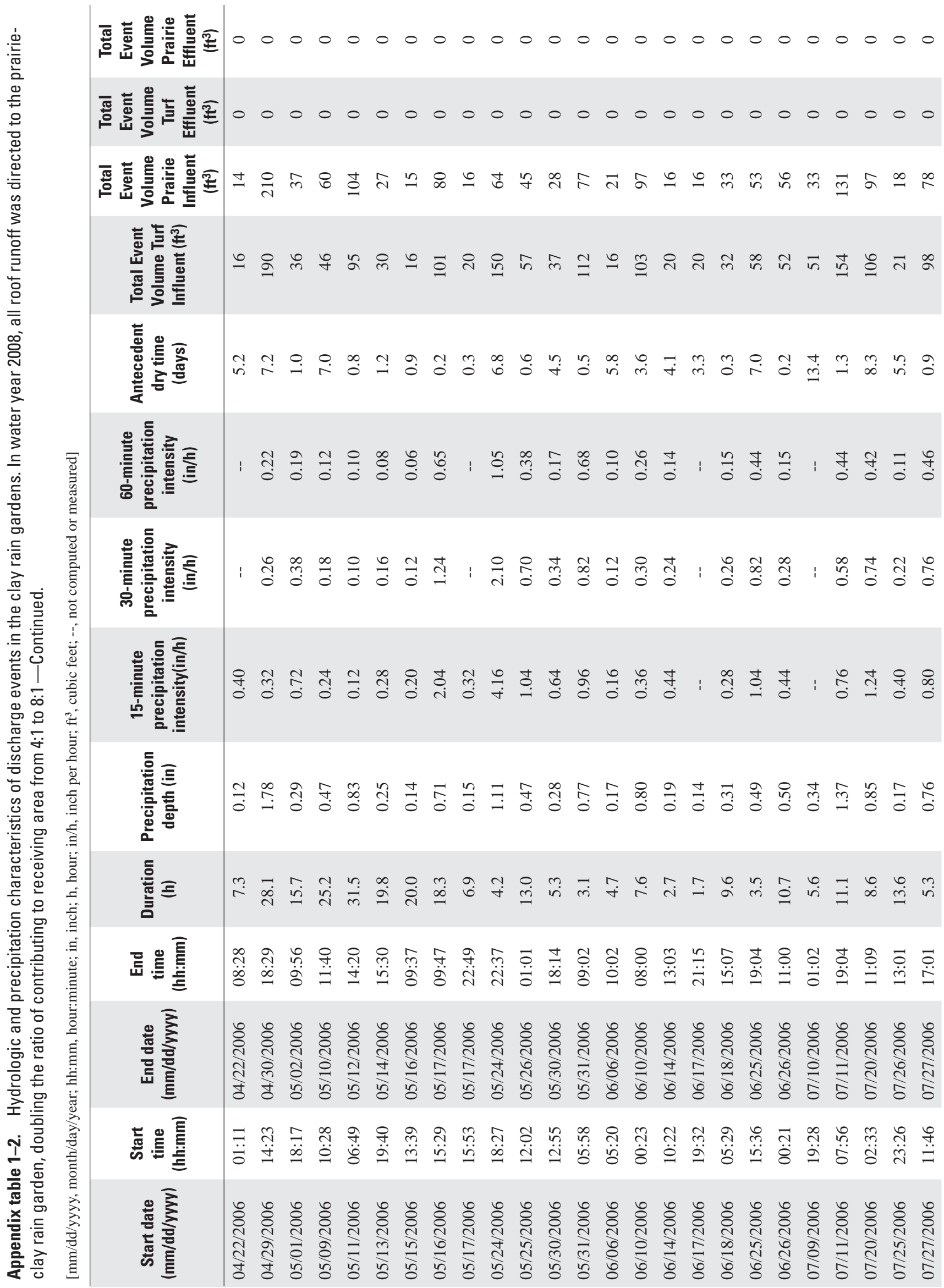




\begin{tabular}{|c|c|c|c|c|c|c|c|c|c|c|c|c|c|c|c|c|c|c|c|c|c|c|c|c|c|c|c|}
\hline . & & 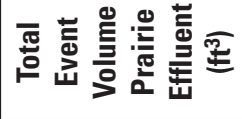 & 0 & 0 & 0 & 0 & 0 & 0 & 0 & 0 & 0 & 0 & 0 & 0 & 0 & 0 & 0 & 0 & 0 & 0 & 0 & 0 & 0 & 0 & 0 & & 0 \\
\hline 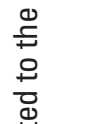 & & 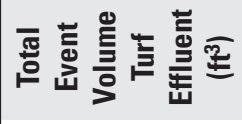 & 0 & 0 & 0 & 으 & 0 & 0 & 0 & 0 & 0 & 0 & 0 & 0 & 0 & 0 & 0 & 0 & 0 & 0 & 0 & 0 & 0 & 0 & 0 & 0 & 0 \\
\hline 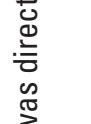 & & 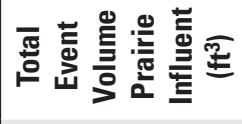 & $\Xi$ & $\stackrel{n}{2}$ & ڤి & $\stackrel{\infty}{\simeq}$ & 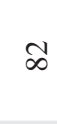 & $\stackrel{\vartheta}{q}$ & ৯े & $\stackrel{\widehat{\gamma}}{ }$ & $\Xi$ & I & gे & nn & $\stackrel{⿱}{\sim}$ & ปิ & 守 & $\hat{\imath}$ & mे & ㄱ & ले & 8 & $=$ & 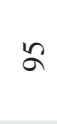 & \& & $\hat{n}$ & 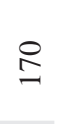 \\
\hline 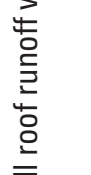 & & 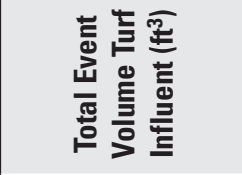 & $\Xi$ & $\stackrel{\infty}{-}$ & $\bar{\lambda}$ & ટ્లి & $\infty$ & $\bar{n}$ & กี & to & $\Xi$ & 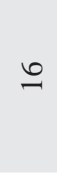 & 8 & in & 8 & $\stackrel{d}{\sim}$ & $\mathscr{F}$ & ৯े & ले & $\bar{n}$ & ㄱ & $\Xi$ & గి & $\Xi$ & $\stackrel{F}{F}$ & n' & $\stackrel{\infty}{=}$ \\
\hline ב. & & 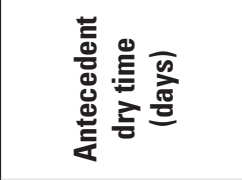 & $\tilde{a}$ & $\exists$ & 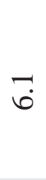 & $\overrightarrow{0}$ & $\tilde{o}$ & స̆ & $\tilde{o}$ & $\dot{n}$ & $\stackrel{0}{\infty}$ & $\stackrel{\text { Iִ }}{-}$ & 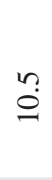 & గె & $\vec{n}$ & 工 & $\stackrel{+}{i}$ & $\overrightarrow{0}$ & $\stackrel{+}{\infty}$ & $\stackrel{\infty}{-}$ & $\stackrel{\sim}{\check{z}}$ & $\tilde{0}$ & $\stackrel{\infty}{0}$ & ¿ें & $\hat{0}$ & $\stackrel{\Gamma_{0}}{ }$ & $\vec{g}$ \\
\hline 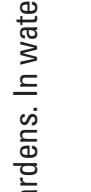 & 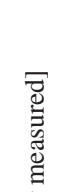 & 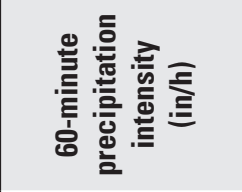 & กิ & $=$ & రై & $\stackrel{\overbrace{}}{\overbrace{}}$ & గి & $\stackrel{\text { ஸे }}{0}$ & $\frac{1}{0}$ & $\stackrel{n}{n}$ & $\stackrel{1}{0}$ & $\stackrel{8}{\circ}$ & ñ & $\stackrel{\circ}{0}$ & సై & $\stackrel{\infty}{0}$ & oे & $\stackrel{5}{0}$ & $\frac{9}{0}$ & $\stackrel{0}{\circ}$ & $\frac{n}{0}$ & $\frac{9}{0}$ & $\stackrel{0}{0}$ & $\frac{1}{0}$ & กี & ๗ֶ? & i \\
\hline 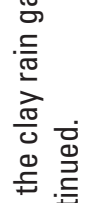 & 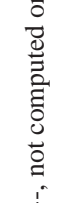 & 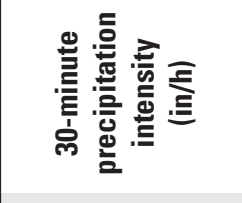 & గి & ָ̃ & $\stackrel{0}{\rightleftarrows}$ & 苛 & ণ̊+ & సָ & $\frac{\infty}{0}$ & $\begin{array}{l}\infty \\
\infty \\
0\end{array}$ & $\frac{0}{0}$ & $\frac{1}{0}$ & 苞 & $\stackrel{0}{0}$ & $\stackrel{+}{ٍ}$ & $\frac{1}{0}$ & $\stackrel{0}{0}$ & $\stackrel{\infty}{\circ}$ & ָุ & $\stackrel{\infty}{0}$ & ণิ & ণั & $\stackrel{\infty}{0}$ & $\frac{\infty}{0}$ & $\stackrel{\infty}{\dddot{m}}$ & గొ & i \\
\hline 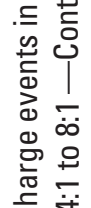 & 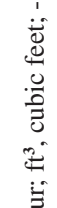 & 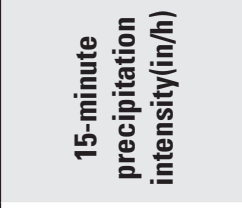 & ?ొ? & $\stackrel{+}{\sim}$ & તે & 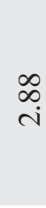 & $\stackrel{N}{0}$ & లె & $\stackrel{\text { İ }}{0}$ & $\underset{8}{8}$ & $\frac{1}{0}$ & $\stackrel{0}{0}$ & $\begin{array}{l}0 \\
0 \\
0\end{array}$ & $\frac{0}{0}$ & กี & $\stackrel{0}{0}$ & $\frac{0}{0}$ & $\frac{1}{0}$ & $\stackrel{\text { ָొ }}{0}$ & $\frac{N}{0}$ & กี & กี & $\frac{1}{0}$ & กิ & $\underset{0}{\sharp}$ & $\stackrel{0}{9}$ & i \\
\hline 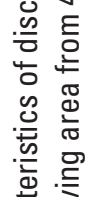 & 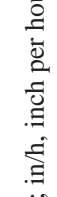 & 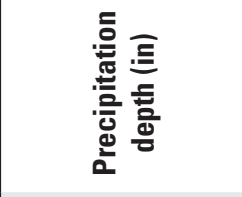 & $\hat{\sigma}$ & $\stackrel{5}{0}$ & $\stackrel{n}{\sigma}$ & 므 & $\stackrel{+}{\overparen{0}}$ & $\stackrel{+}{+}$ & $\stackrel{\infty}{\stackrel{\infty}{0}}$ & $\vec{b}$ & $\frac{1}{0}$ & $\bar{ত}$ & $\stackrel{n}{f}$ & ñ & $\stackrel{1}{\infty}$ & $\stackrel{\circ}{0}$ & $\stackrel{n}{\sharp}$ & $\stackrel{\overbrace{}}{0}$ & กี & $\stackrel{n}{\ominus}$ & $\vec{n}$ & $\underset{\sigma}{\sigma}$ & ำ & $\stackrel{0}{0}$ & $\hat{n}$ & $\stackrel{\mathfrak{H}}{\circ}$ & 莺 \\
\hline 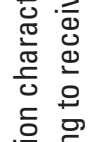 & 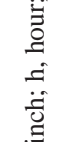 & 墪 & $\stackrel{n}{r}$ & ָூ & $\Xi$ & $\hat{\infty}$ & $\stackrel{n}{r}$ & $\begin{array}{l}\infty \\
\dot{m}\end{array}$ & $\stackrel{\eta}{\forall}$ & $\ddot{n}$ & $\stackrel{1}{0}$ & $\stackrel{\vartheta}{+}$ & $m_{\infty}^{\infty}$ & $\stackrel{\sim}{\infty}$ & I & $n$ & $\ddot{n}$ & $\begin{array}{l}\infty \\
\dot{J}\end{array}$ & $\dot{m}$ & $\stackrel{\text { }}{\stackrel{\sim}{d}}$ & iे & $\stackrel{\infty}{\ddot{n}}$ & $\stackrel{\infty}{\stackrel{\lambda}{~}}$ & $\stackrel{\sim}{\infty}$ & $\vec{a}$ & $\begin{array}{l}0 \\
\ddot{d}\end{array}$ & n̊ \\
\hline 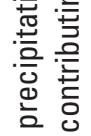 & 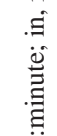 & 을 豆至 & $\begin{array}{l}\stackrel{o}{ } \\
\dot{g}\end{array}$ & $\frac{\stackrel{+}{~}}{\stackrel{\vec{\lambda}}{ }}$ & 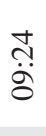 & $\stackrel{\infty}{\stackrel{n}{\sim}}$ & $\begin{array}{l}\text { ஸे } \\
\stackrel{\Xi}{\Xi}\end{array}$ & $\stackrel{\stackrel{\forall}{\sim}}{\stackrel{\sim}{\sim}}$ & $\begin{array}{l}\stackrel{\overbrace{}}{\ddot{g}} \\
\text { }\end{array}$ & $\underset{\ddot{\sim}}{\stackrel{\nabla}{\Delta}}$ & $\begin{array}{l}\stackrel{8}{\dot{0}} \\
\dot{\phi}\end{array}$ & $\stackrel{n}{\ddot{\infty}}$ & $\begin{array}{l}\stackrel{8}{\mathscr{J}} \\
\dot{\dot{I}}\end{array}$ & $\stackrel{\infty}{\stackrel{\infty}{ \pm}}$ & $\overline{\ddot{g}}$ & 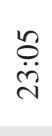 & $\stackrel{n}{\mathscr{o}}$ & $\ddot{\ddot{\theta}}$ & $\begin{array}{l}\stackrel{\oplus}{\mathscr{n}} \\
\stackrel{n}{n}\end{array}$ & $\stackrel{\stackrel{\Im}{\ddot{ \pm}}}{ }$ & $\begin{array}{c}\bar{\Xi} \\
\ddot{\delta}\end{array}$ & $\stackrel{\infty}{\stackrel{\infty}{\check{\sigma}}}$ & $\frac{n}{\ddot{n}}$ & $\begin{array}{l}\stackrel{D}{n} \\
\stackrel{n}{n}\end{array}$ & $\begin{array}{l}\tilde{o} \\
\stackrel{\operatorname{n}}{ }\end{array}$ & $\stackrel{\bar{\theta}}{\ddot{\theta}}$ & 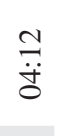 \\
\hline 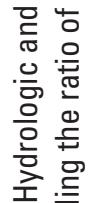 & 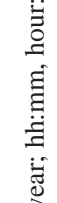 & 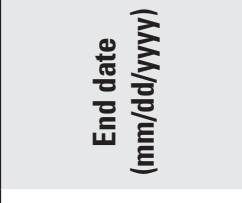 & 离 & 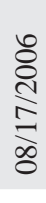 & 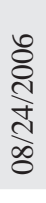 & 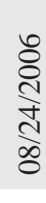 & $\begin{array}{l}\stackrel{8}{8} \\
\stackrel{1}{2} \\
\stackrel{1}{\delta}\end{array}$ & 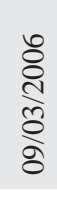 & 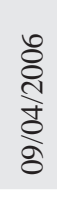 & $\frac{8}{8}$ & 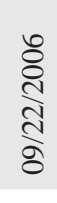 & 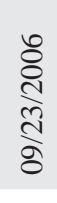 & 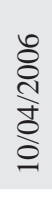 & $\begin{array}{l}\stackrel{8}{8} \\
\stackrel{\Xi}{\Xi} \\
\vdots\end{array}$ & 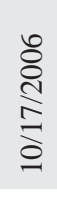 & 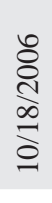 & 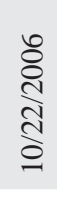 & 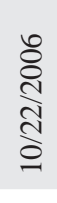 & 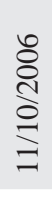 & 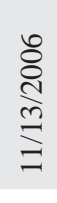 & 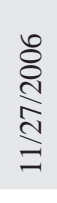 & 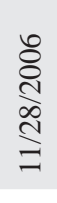 & 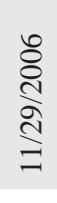 & 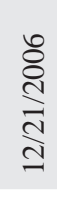 & 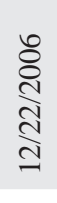 & 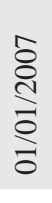 & $\begin{array}{l}\hat{8} \\
\text { ì } \\
\text { ปे } \\
\text { ล } \\
\text { o }\end{array}$ \\
\hline 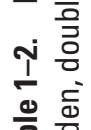 & 文 & 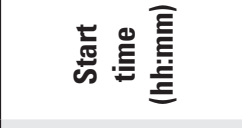 & $\stackrel{m}{\ddot{n}}$ & $\begin{array}{l}\bar{n} \\
\dot{+}\end{array}$ & $\stackrel{\infty}{\underset{\sim}{\sim}}$ & $\stackrel{n}{\stackrel{n}{\sim}} \underset{ }{\sim}$ & $\frac{m}{\ddot{\sigma}}$ & $\begin{array}{l}\infty \\
\stackrel{n}{\check{ユ}}\end{array}$ & $\underset{\ddot{ஜ}}{\stackrel{\Xi}{ஜ}}$ & $\begin{array}{l}n \\
\stackrel{n}{8} \\
\ddot{\delta}\end{array}$ & 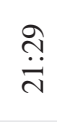 & $\begin{array}{l}\stackrel{\oplus}{\sim} \\
\ddot{n}\end{array}$ & $\underset{\ddot{\theta}}{\ddot{\theta}}$ & ڤે & $\begin{array}{l}\stackrel{\oplus}{n} \\
\stackrel{n}{n}\end{array}$ & 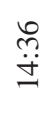 & 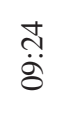 & $\begin{array}{l}\stackrel{\sim}{~} \\
\stackrel{\Xi}{\Xi}\end{array}$ & $\stackrel{\circ}{\stackrel{+}{\leftrightarrows}}$ & $\stackrel{n}{\ddot{g}}$ & $\underset{n}{\stackrel{n}{0}}$ & $\begin{array}{l}\stackrel{\partial}{\grave{\infty}} \\
\stackrel{\infty}{-}\end{array}$ & $\begin{array}{l}\stackrel{0}{~} \\
\ddot{\delta}\end{array}$ & $\stackrel{\curvearrowleft}{\stackrel{n}{\sigma}}$ & $\begin{array}{l}\infty \\
\stackrel{n}{6} \\
\stackrel{n}{\delta}\end{array}$ & $\frac{\check{\pi}}{\check{\sigma}}$ & $\begin{array}{l}\tilde{n} \\
\ddot{g}\end{array}$ \\
\hline 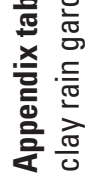 & 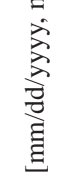 & 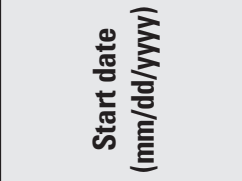 & 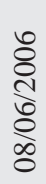 & 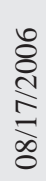 & 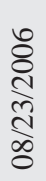 & 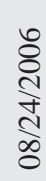 & 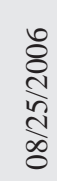 & 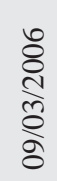 & 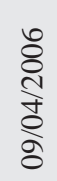 & $\begin{array}{l}\stackrel{8}{8} \\
\stackrel{1}{0} \\
\frac{1}{8}\end{array}$ & 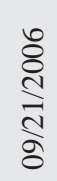 & 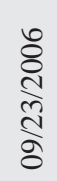 & 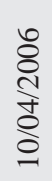 & 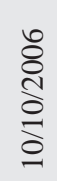 & 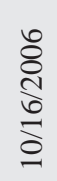 & $\begin{array}{l}\stackrel{8}{8} \\
\substack{1 \\
\infty} \\
\vdots\end{array}$ & 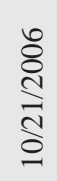 & 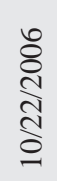 & ֻٕ & 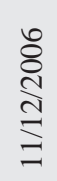 & 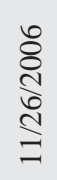 & 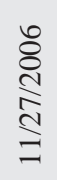 & 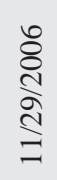 & 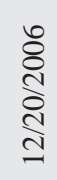 & 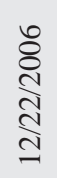 & 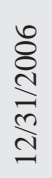 & 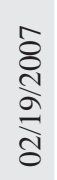 \\
\hline
\end{tabular}




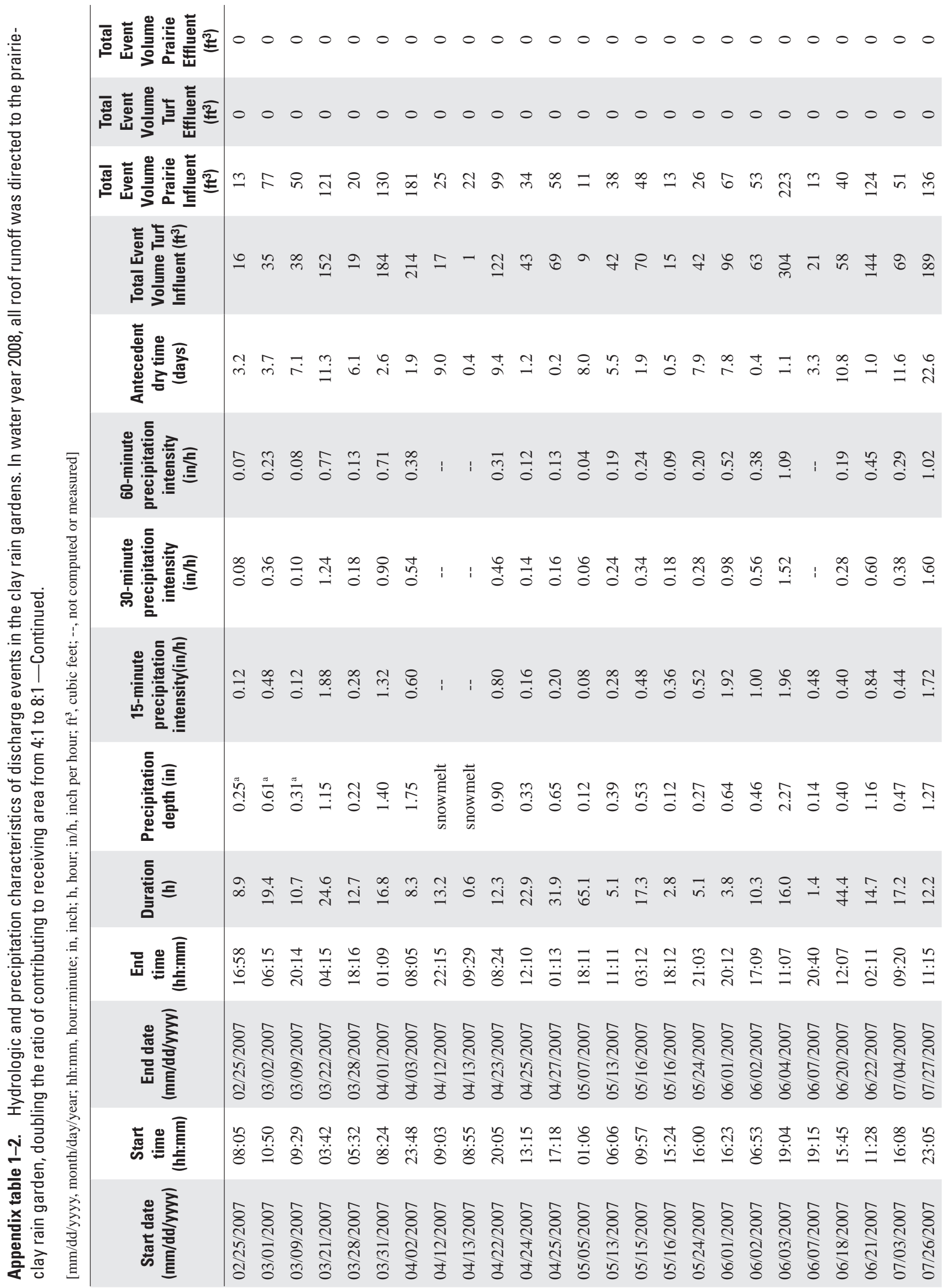




\begin{tabular}{|c|c|c|c|c|c|c|c|c|c|c|c|c|c|c|c|c|c|c|c|c|c|c|c|c|c|c|c|c|c|}
\hline . & & 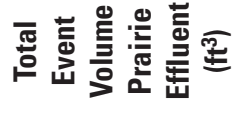 & 0 & 0 & 0 & 0 & 0 & & 0 & 0 & 0 & 0 & 0 & 0 & 0 & 00 & & 0 & 0 & 0 & 0 & 0 & 0 & 0 & 0 & 0 & 0 & 0 & 0 \\
\hline 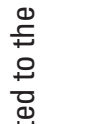 & & 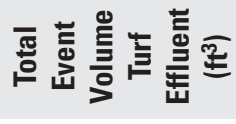 & 0 & 0 & 0 & 0 & $\simeq$ & 0 & 0 & 0 & 0 & 0 & 0 & 0 & 0 & 00 & & 0 & 0 & 0 & 0 & 0 & 0 & 0 & i & i & i & i & i \\
\hline 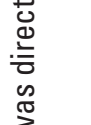 & & 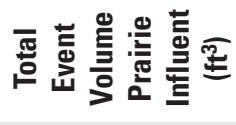 & $\stackrel{\nabla}{\sim}$ & নิ & in & fo & $\stackrel{\text { \& }}{\text { d }}$ & & 6 & ஓి & in & ᄏ & $\underline{\sigma}$ & $\stackrel{9}{-}$ & $\stackrel{m}{=}$ & $\alpha \sigma$ & & ஏ & $\mathbb{\infty}^{+}$ & 年 & 응 & $\infty$ & $\vec{m}$ & $n$ & ケ & 6 & $\cong$ & त & $\sqrt[n]{n}$ \\
\hline 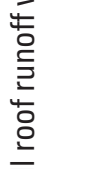 & & 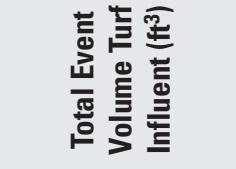 & चे & +े & 2 & $\stackrel{n}{n}$ & $\stackrel{\nabla}{v}$ & & 0 & $\stackrel{\Re}{7}$ & $\overline{6}$ & $\stackrel{?}{f}$ & $\stackrel{2}{2}$ & 9 & \pm & 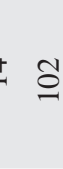 & & f & ஃ & $n$ & o & $\infty$ & fo & $\infty$ & i & i & i & i & i \\
\hline $\begin{array}{l}\text { থิ } \\
\frac{1}{\pi} \\
\searrow \\
\searrow\end{array}$ & & 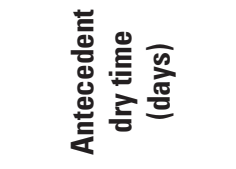 & $\underset{\infty}{-}$ & Э & $\stackrel{0}{-}$ & $\stackrel{b}{i}$ & $\stackrel{\circ}{-}$ & & e. & ָָ & rִ & ? & ?̊? & $\stackrel{m}{0}$ & $\overrightarrow{0}$ & $\dot{0}$ & & כָ & $\begin{array}{l}0 \\
i\end{array}$ & $\stackrel{\Upsilon}{0}$ & $\hat{\jmath}$ & $=$ & $\stackrel{b}{m}$ & $\vec{n}$ & $\stackrel{?}{-}$ & $\begin{array}{l}0 \\
\dot{n}\end{array}$ & n & $\stackrel{0}{\circ}$ & 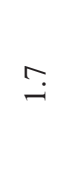 \\
\hline 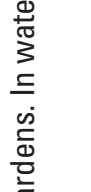 & 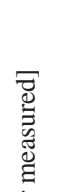 & 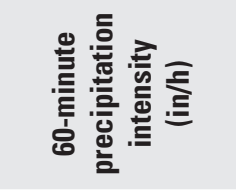 & $\stackrel{n}{f}$ & $\frac{\pi}{0}$ & $\stackrel{\vartheta}{+}$ & i & $\stackrel{n}{2}$ & & $\frac{n}{0}$ & חִ & $\frac{5}{0}$ & $\stackrel{\infty}{0}$ & م્ & $\frac{1}{0}$ & $\overline{0}$ & 5 & & 1 & $\stackrel{n}{0}$ & $\stackrel{\infty}{\circ}$ & ๙̃? & ْ̊?. & $\frac{\infty}{0}$ & กิ & กิ & i & $\stackrel{n}{0}$ & $\stackrel{ \pm}{0}$ & กิ \\
\hline 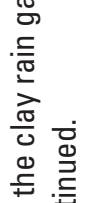 & 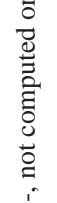 & 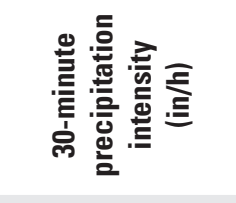 & ?ִ & กิ & 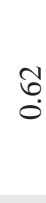 & $\stackrel{?}{0}$ & $\stackrel{\infty}{-}$ & $\approx$ & הָ & 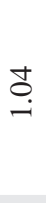 & กุ & గి & ? & กิ & ָ̃ & ! & & 1 & $\stackrel{0}{+}$ & m़ & లి & $\stackrel{?}{\circ}$ & ?ి & $\stackrel{+}{+}$ & 웅 & i & $\stackrel{0}{\circ}$ & กิ & $\stackrel{尺}{\circ}$ \\
\hline 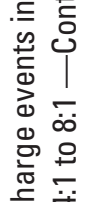 & 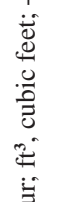 & 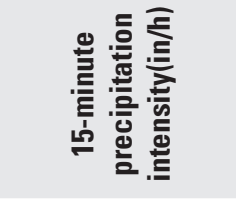 & $\begin{array}{l}\infty \\
0 \\
0\end{array}$ & $\stackrel{\infty}{\infty}$ & 广ా & $\stackrel{0}{=}$ & $\stackrel{?}{\stackrel{9}{+}}$ & & ב̂ & $\underset{-}{\text { 寸 }}$ & $\stackrel{8}{8}$ & ஜn & $\stackrel{\infty}{\stackrel{+}{\sim}}$ & 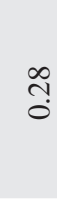 & ?ి & ? & & . & $\stackrel{\infty}{\infty}$ & n̊? & กี & 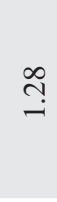 & ?ొ & ợ & $\begin{array}{l}\infty \\
\infty \\
0\end{array}$ & i & ஸి & ป̊ & ô \\
\hline 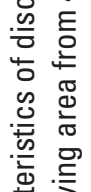 & 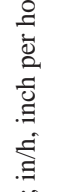 & 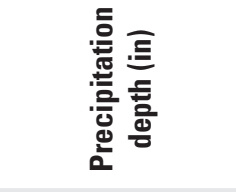 & \begin{tabular}{l}
\multirow{J}{J}{} \\
ì
\end{tabular} & $\stackrel{\infty}{\infty}$ & $\stackrel{+}{0}$ & $\underset{0}{\nabla}$ & $\stackrel{1}{i}$ & 'n & ? & $\begin{array}{l}\bar{\infty} \\
\dot{r}\end{array}$ & $\stackrel{n}{n}$ & $\hat{n}$ & n̊ & $\stackrel{9}{\circ}$ & $\frac{n}{0}$ & {$\left[\begin{array}{l}0 \\
0 \\
0\end{array}\right.$} & & 官 & $\stackrel{?}{\stackrel{0}{0}}$ & $\stackrel{m}{\leftrightarrow}$ & $\hat{a}$ & ñ & $\stackrel{\infty}{\stackrel{0}{0}}$ & $\frac{0}{0}$ & $\stackrel{\text { o }}{+}$ & $\stackrel{\stackrel{\circ}{0}}{\circ}$ & $\stackrel{\tilde{o}}{0}$ & $\stackrel{F}{0}$ & $\stackrel{\cap}{n}$ \\
\hline 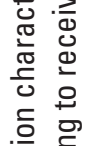 & 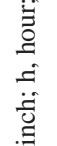 & 흫 & ते & $\begin{array}{l}0 \\
\stackrel{0}{0}\end{array}$ & $\stackrel{?}{r}$ & $\stackrel{+}{\circ}$ & n? & $\stackrel{\infty}{\infty}$ & 赵 & $\stackrel{n}{\sim}$ & $\underset{\mathrm{i}}{\stackrel{+}{\mathrm{N}}}$ & $\stackrel{n}{r}$ & $\begin{array}{l}\infty \\
\dot{n}\end{array}$ & $ت$ & $\exists$ & i & & $\begin{array}{l}0 \\
\dot{m}\end{array}$ & $\stackrel{?}{+}$ & $\stackrel{\circ}{\stackrel{+}{ \pm}}$ & $\stackrel{0}{=}$ & $\stackrel{r}{r}$ & $\stackrel{0}{0}$ & $\stackrel{m}{m}$ & $\stackrel{\infty}{+}$ & $\stackrel{9}{-}$ & $\stackrel{\Upsilon}{\check{I}}$ & $\begin{array}{l}0 \\
\stackrel{\Omega}{ }\end{array}$ & $\stackrel{\infty}{\sigma}$ \\
\hline 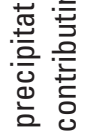 & 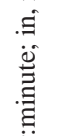 & 豆㤩豆 & $\hat{n}$ & $\begin{array}{l}\stackrel{ }{~} \\
\ddot{n}\end{array}$ & 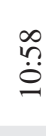 & $\underline{\underline{ }}$ & 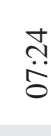 & $\dot{\Xi}$ & نِ & 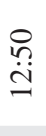 & ڤִ & $\begin{array}{l}\bar{n} \\
\ddot{0}\end{array}$ & $\frac{\widetilde{N}}{\stackrel{\sim}{*}}$ & $\begin{array}{l}\Xi \\
\Xi\end{array}$ & 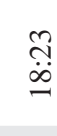 & $\begin{array}{l}7 \\
0 \\
0\end{array}$ & & ڤِ & 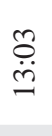 & $\begin{array}{l}\text { ț } \\
\dot{\phi}\end{array}$ & 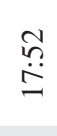 & $\frac{\curvearrowright}{\ddot{\beth}}$ & $\bar{\Xi}$ & $\begin{array}{l}\tilde{n} \\
\stackrel{0}{0}\end{array}$ & $\begin{array}{l}\stackrel{8}{\ddot{~}} \\
\text { ते }\end{array}$ & $\begin{array}{l}8 \\
\stackrel{\dot{\Xi}}{ }\end{array}$ & $\begin{array}{l}\stackrel{0}{\ddot{n}} \\
\underline{\text { n }}\end{array}$ & $\begin{array}{l}\stackrel{\overbrace{}}{\ddot{J}} \\
\dot{\mathrm{d}}\end{array}$ & $\frac{n}{\ddot{b}}$ \\
\hline 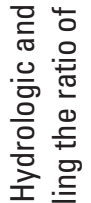 & 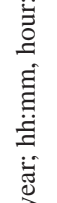 & 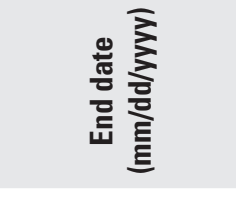 & 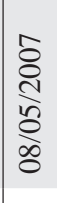 & 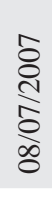 & $\begin{array}{l}\hat{8} \\
\stackrel{1}{\Omega} \\
\stackrel{8}{\infty} \\
0\end{array}$ & $\frac{\substack{8 \\
\stackrel{2}{2}}}{\stackrel{\infty}{\circ}}$ & 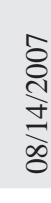 & $\frac{\mathfrak{c}}{2}$ & 赵 & 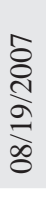 & 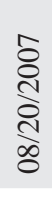 & 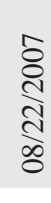 & 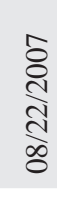 & 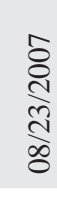 & 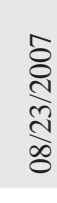 & 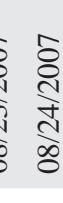 & & 位 & 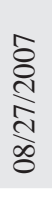 & 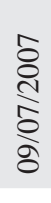 & $\frac{\hat{s}}{8}$ & 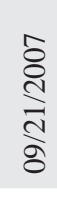 & 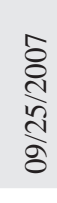 & 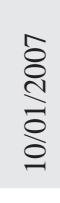 & 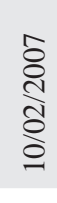 & $\begin{array}{l}\hat{\delta} \\
\text { న } \\
\infty \\
\stackrel{0}{0}\end{array}$ & 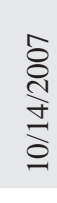 & 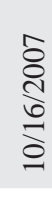 & 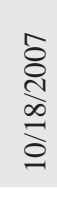 \\
\hline $\begin{array}{l}\text { 을 } \\
\text { 음 } \\
\text { 둥 }\end{array}$ & 胥 & 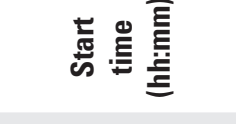 & $\begin{array}{l}\stackrel{\infty}{\sim} \\
\stackrel{\sim}{\sim}\end{array}$ & $\begin{array}{l}\stackrel{+}{\mathrm{I}} \\
\text { ठ̀ }\end{array}$ & ले & 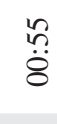 & $\begin{array}{l}\stackrel{\circ}{\dot{j}} \\
\text { ஸे }\end{array}$ & $\frac{1}{\dot{\lambda}}$ & $\frac{\pi}{\tilde{\sigma}}$ & $\frac{a}{\ddot{g}}$ & $\begin{array}{l}\tilde{n} \\
\ddot{\infty} \\
\ddot{0}\end{array}$ & $\frac{\infty}{\ddot{\sigma}}$ & $\begin{array}{l}\text { } \\
\stackrel{n}{n} \\
\end{array}$ & $\frac{\nearrow}{\ddot{\Xi}}$ & $\stackrel{\check{\Xi}}{\ddot{\Xi}}$ & 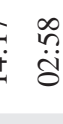 & & ○ِ & $\begin{array}{c}\stackrel{f}{\dot{\theta}} \\
\dot{\otimes}\end{array}$ & $\begin{array}{l}\mathscr{C} \\
\dot{\infty} \\
-\end{array}$ & $\stackrel{\bar{\wp}}{\ddot{\circ}}$ & $\begin{array}{l}\mathscr{C} \\
\stackrel{\theta}{2}\end{array}$ & $\begin{array}{l}\stackrel{0}{\ddot{n}} \\
\underline{-1}\end{array}$ & $\begin{array}{l}\infty \\
\stackrel{\stackrel{n}{\sim}}{\sim}\end{array}$ & $\frac{m}{\ddot{I}}$ & $\stackrel{\unlhd}{\stackrel{\Xi}{I}}$ & $\stackrel{n}{\delta}$ & 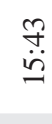 & ํํํ \\
\hline 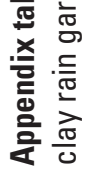 & 交 & 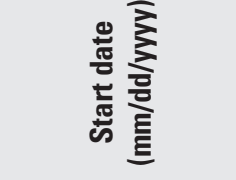 & 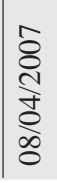 & 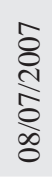 & 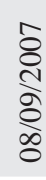 & 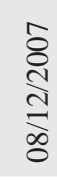 & 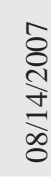 & $\begin{array}{l}\frac{\pi}{2} \\
\vdots \\
\frac{1}{\infty}\end{array}$ & 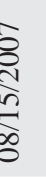 & 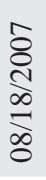 & 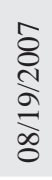 & 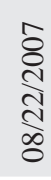 & 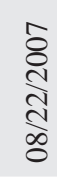 & $\begin{array}{l}\hat{\delta} \\
\stackrel{8}{1} \\
\stackrel{1}{\infty} \\
\delta\end{array}$ & 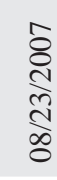 & 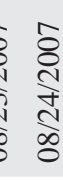 & $\frac{\mathfrak{c}}{\mathfrak{s}}$ & 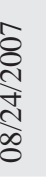 & 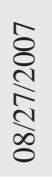 & $\begin{array}{l}\frac{1}{8} \\
\frac{1}{8} \\
\frac{8}{8}\end{array}$ & 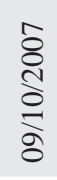 & 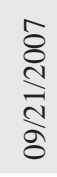 & 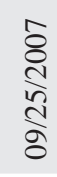 & $\begin{array}{l}\hat{\delta} \\
\text { ì } \\
\text { on } \\
\text { gి }\end{array}$ & 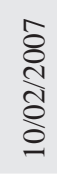 & 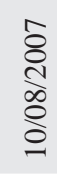 & 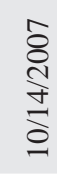 & $\begin{array}{l}\hat{\delta} \\
\frac{1}{n} \\
\frac{\delta}{2}\end{array}$ & 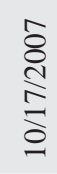 \\
\hline
\end{tabular}




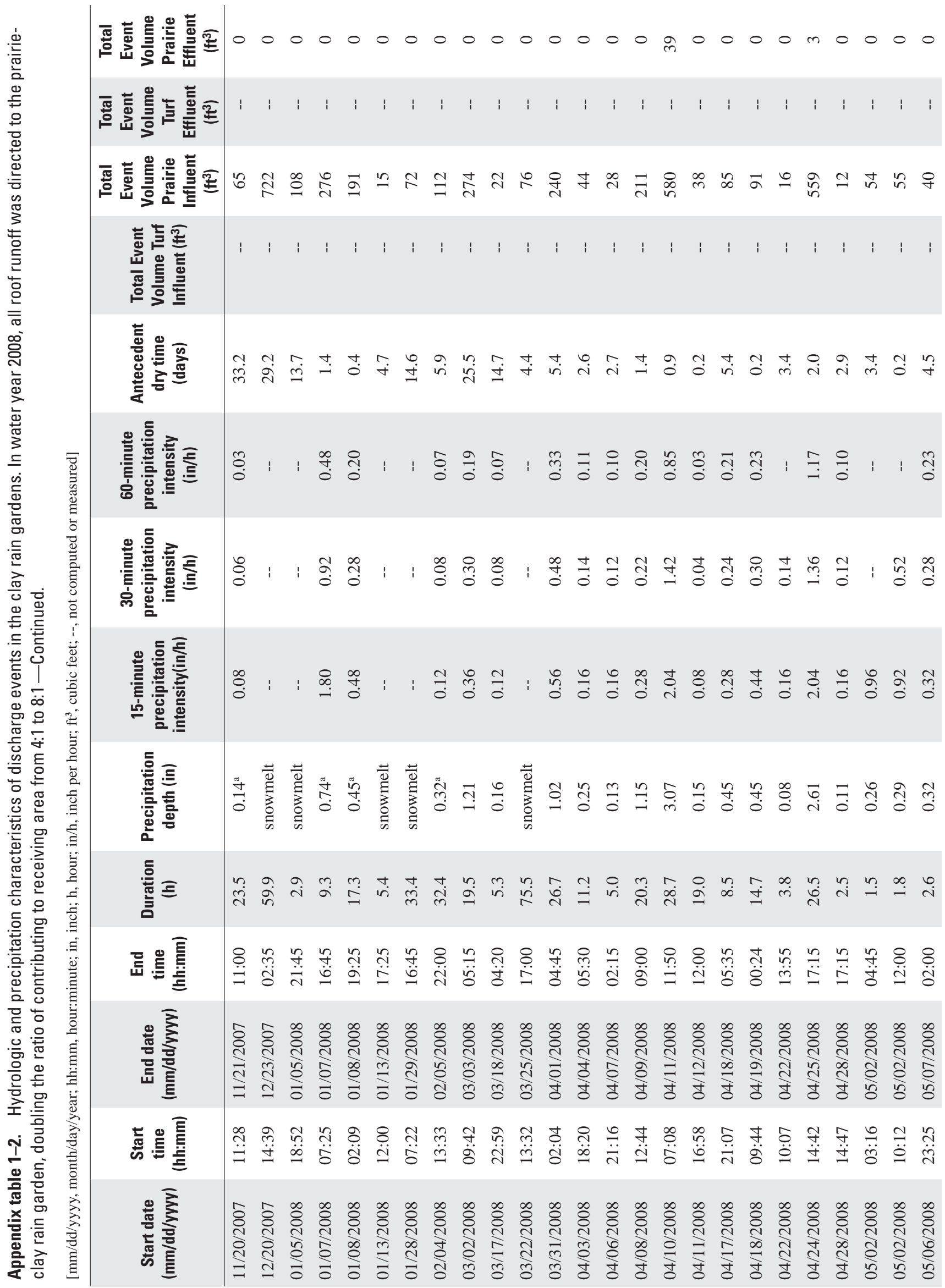




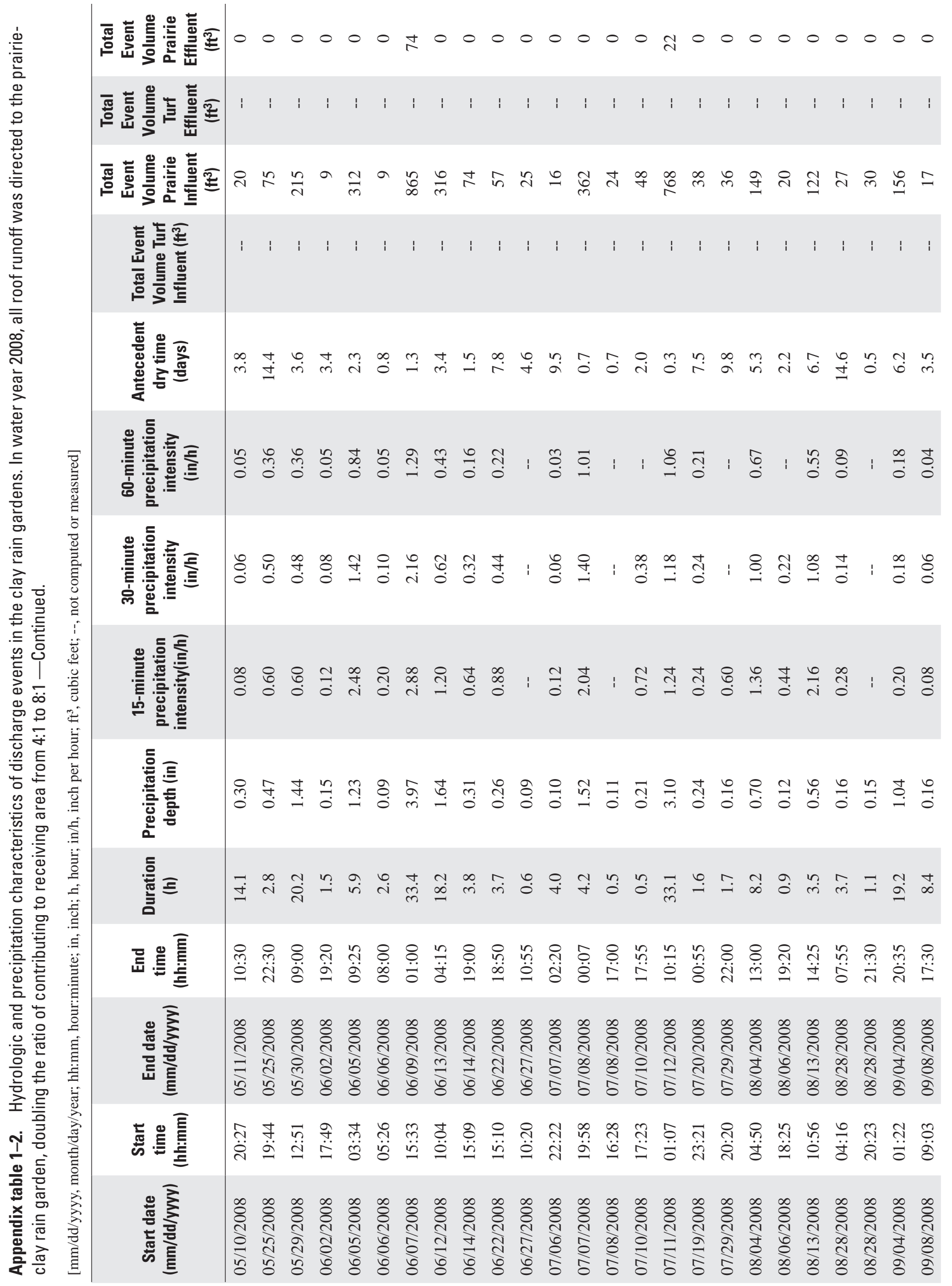




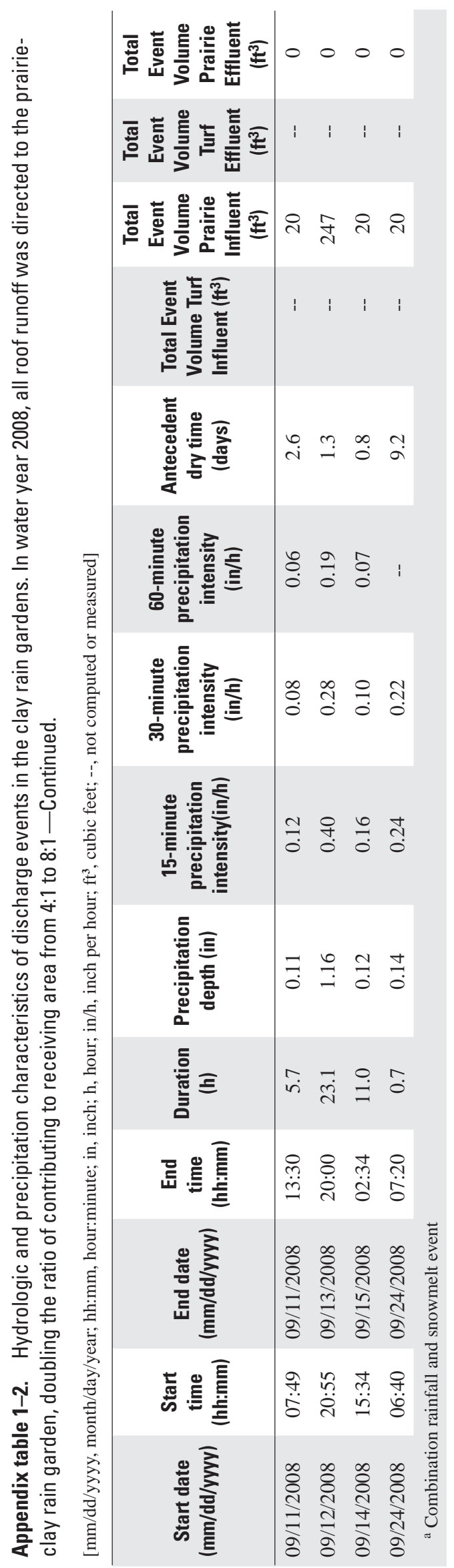


72 Turf-Grass and Prairie-Vegetated Rain Gardens in a Clay and Sandy Soil: Madison, Wisconsin, Water Years 2004-08

This page left intentionally blank 
Publishing support provided by the U.S. Geological Survey

Publishing Network, Columbus and Tacoma Publishing Service Centers

For more information concerning the research in this report, contact the

Director, Wisconsin Water Science Center

U.S. Geological Survey

8505 Research Way

Middleton, Wisconsin 53562

http://wi.water.usgs.gov/ 


\section{娚}

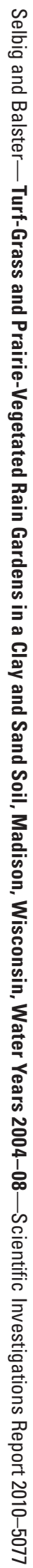

